Andrews University

Digital Commons @ Andrews University

\title{
A Study of the Concomitant Problems Facing Most of the "At-Risk" African American Students in the Benton Harbor Elementary School System: A Case for an Alternative Model
}

Simon M. Honore

Andrews University

Follow this and additional works at: https://digitalcommons.andrews.edu/dissertations

Part of the African American Studies Commons, and the Elementary Education Commons

\section{Recommended Citation}

Honore, Simon M., "A Study of the Concomitant Problems Facing Most of the "At-Risk" African American Students in the Benton Harbor Elementary School System: A Case for an Alternative Model" (1996).

Dissertations. 1715.

https://digitalcommons.andrews.edu/dissertations/1715

https://dx.doi.org/10.32597/dissertations/1715

This Dissertation is brought to you for free and open access by the Graduate Research at Digital Commons @ Andrews University. It has been accepted for inclusion in Dissertations by an authorized administrator of Digital Commons@ Andrews University. For more information, please contact repository@andrews.edu. 


\section{ABSTRACT}

\section{A STUDY OF THE CONCOMITANT PROBLEMS FACING MOST OF THE "AT-RISK" AFRICAN AMERICAN STUDENTS IN THE BENTON HARBOR ELEMENTARY SCHOOL SYSTEM: \\ A CASE FOR AN ALTERNATIVE MODEL}

\section{by}

\section{Simon M. Honoré}

Chair: Bernard M. Lall 


\title{
ABSTRACT OF GRADUATE STUDENT RESEARCH \\ Dissertation
}

\author{
Andrews University \\ School of Education
}

\begin{abstract}
Title: A STUDY OF THE CONCOMITANT PROBLEMS FACING MOST OF THE "AT-RISK" AFRICAN AMERICAN STUDENTS IN THE BENTON HARBOR ELEMENTARY SCHOOL SYSTEM: A CASE FOR AN ALTERNATIVE MODEL

Name of researcher: Simon M. Honoré

Name and degree of faculty chair: Bernard M. Lall, Ph.D. Date completed: July 1996
\end{abstract}

\section{Problem}

It would appear that the problem of school truancy, retention, and subsequent academic failure is a major educational crisis which puts most of the African American students at risk in the Benton Harbor area schools.

\section{Purpose}

The purpose of this study has been to determine the concomitant educational problems facing the "at-risk" African American students in the Benton Harbor Elementary school system and to suggest positive changes through an alternative model. 
Results

The results of the survey indicated that approximately $90-95 \%$ of Benton Harbor educators agreed to changes. Administrators and teachers strongly agreed that the recommendations, based on the findings, if implemented, would be considered as positive changes in the learning difficulties observed among the at-risk African American pupils in Benton Harbor primary schools. The survey first spelled out the observed educational difficulties of the African American at-risk elementary students in Benton Harbor.

second, it indicated that recommendations based on the results, if implemented, will positively affect the educational needs of the at-risk African American students in the Benton Harbor primary school system.

\section{Conclusions}

Based on the findings of this study in chapter 4 , and based on the review of related literature in chapter 2 , ten conclusions have been drawn. They are reported in chapter 5 .

\section{Recommendations}

Eight recommendations are made with a view to provide discussion and further study. They are developed in chapter 5 . 


\author{
Andrews University \\ School of Education
}

\begin{abstract}
A STUDY OF THE CONCOMITANT PROBLEMS FACING MOST OF THE "AT-RISK" AFRICAN AMERICAN STUDENTS IN THE BENTON HARBOR ELEMENTARY SCHOOL SYSTEM:

A CASE FOR AN ALTERNATIVE MODEL
\end{abstract}

\author{
A Dissertation \\ Presented in Partial Fulfillment \\ of the Requirements for the Degree \\ Doctor of Philosophy
}

by

Simon M. Honoré

July 1996 
( ) Copyright by Simon M. Honoré 1996 All Rights Reserved 
A STUDY OF THE CONCOMITANT PROBLEMS FACING MOST OF THE "AT-RISK" AFRICAN-AMERICAN STUDENTS IN THE BENTON HARBOR ELEMENTARY SCHOOL SYSTEM:

A CASE FOR AN ALTERNATIVE MODEL

A dissertation

presented in partial fulfillment of the requirements for the degree Doctor of Philosophy

by

SIMON M. HONORÉ

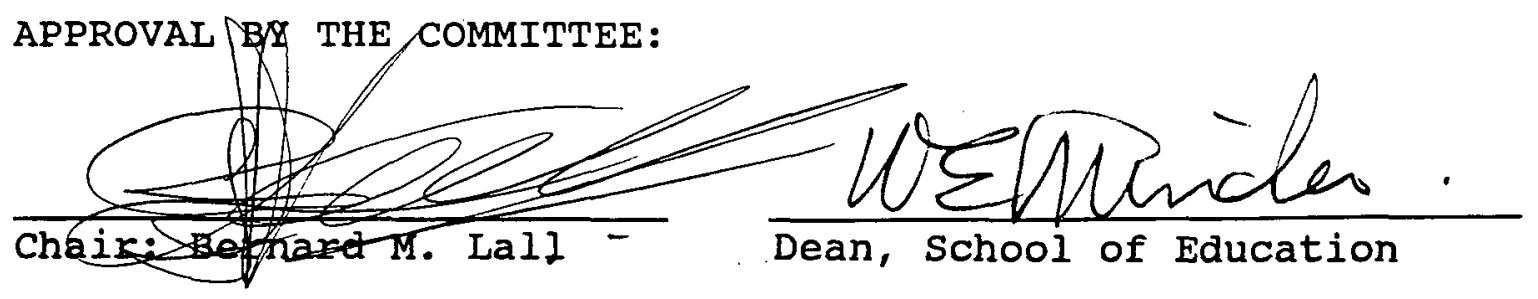

Member: Elsie P Jackson
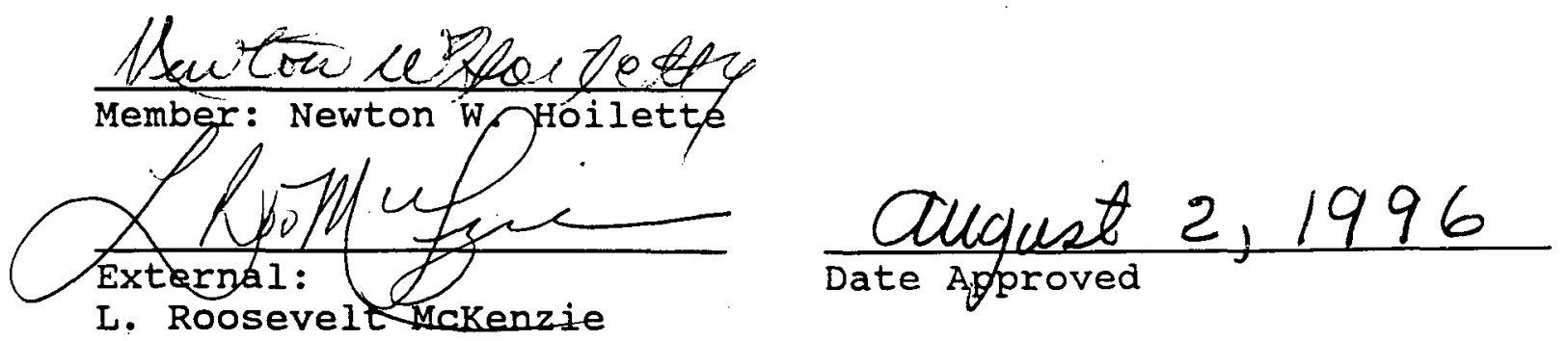
To the memory of my dear parents: my father, Disciple Joseph Honoré, and my mother, Marie-Louise (Siméon) Honoré, who twenty-five years ago went to be with their Heavenly Father, their "ONLY GOOD MASTER" and mine. Their love of knowledge for their nine children and their constant encouragement on my behalf (their last child) incessantly gave me the fortitude to complete my formal education 


\section{Chapter}

I. INTRODUCTION

Background of the Problem . . . . . . . 1

Area Demographics . . . . . . . . . . 1

Statement of the Problem . . . . . . . 5

Purpose of the Study . . . . . . . . 5

Significance of the study . . . . . . . 5

Research questions . . . . . . . . 9

Null Hypotheses . . . . . . . . . . 10

Definition of Terms . . . . . . . . . 10

Delimitations of the study . . . . . . 13

Basic Assumptions . . . . . . . . . . 13

Summary . . . . . . . . . . . . . . . . 14

Organization of the Dissertation . . . . 15

II. REVIEW OF THE LITERATURE . . . . . . . . . 17

Philosophical Preamble . . . . . . . 17

Organization of the Review . . . . . . . 19

The U.S. Academic Academy . . . . . . . 19

Definition . . . . . . . . . . . . 19

Historical Development of U.S.

Academic Academy .. . . . . . . 20

The Literature on Educating African

American Children Successfully . . . . 23

Program Design . . . . . . . . . . . . 27

Components of a Positive Learning climate
for African American Children . . . . . 28

overview of Alternative Education . . . . 30

Alternative Education Defined... . . 30

Educational Potential . . . . . . . 31

Successful Alternative

Education Programs . . . . . . . 32

An "At-Risk" Learner's Incompatible Curriculum . . . . . . . . . . . 37

The Profiles of the "At-Risk" Learners-A Summary of a Jungian-Based style Research Study . . . . . . . . 
"At-Risk" Learners' strategies for

Successful Outcomes . . . . . . . . 40

Reaching "Unreachable" Students . . . . 41

summary . . . . . . . . . . . . . . . 43

The Struggle to Improve American

Education . . . . . . . . . . . . 43

Summary . . . . . . . . . . . . . . . 45

Empowering Elementary African American
Children to Achieve Academic Success . 46

Biases of the U.S. Information

$$
\text { Media ................ } 46
$$

Eight of the Most Important

Factors to Foster Academic

Success . . . . . . . . . . . 47

summary . . . . . . . . . . . . . . 53

Modern Organizational Theory . . . . . . 54

Necessity of a Good Primary Education . . 61

Preschool and Early Childhood

Education May Be Necessary

in Benton Harbor . . . . . . . . . . 63

In the Shadow of the Ivory Tower . . . 68

A Creative Approach Toward
Greater Equity . . . . . . . . . 69

Charting Success . . . . . . . . 70

Summary . . . . . . . . . . . . . . 71

III. METHODOLOGY . . . . . . . . . . . . . 73

Introduction . . . . . . . . . . . 73

Research Questions . . . . . . . . . 74

Null Hypotheses . . . . . . . . . . 74

Hypothesis 1 . . . . . . . . . . . . . 74

Hypothesis 2 . . . . . . . . . . . . . 74

Hypothesis 3 . . . . . . . . . . . . . 75

Hypothesis 4 . . . . . . . . . . . . 75

Research Design . . . . . . . . . . 75

Instrumentation ............. . . . 75

Steps in the Questionnaire Development. . 76

Description of the Questionnaire . . . . 77

Procedure .. . . . . . . . . . . 78

Population and Sample . . . . . . . 79

Summary . . . . . . . . . . . . . 80

IV. PRESENTATION AND ANALYSIS OF DATA • . . . . . 82

Introduction . . . . . . . . . . . 82

Questionnaire Section I . . . . . . 83

Teacher Satisfaction . . . . . . . 83

Question 1... . . . . . . . . . 83

Question 2......... . . . 84

Question 3... . . . . . . . . 85

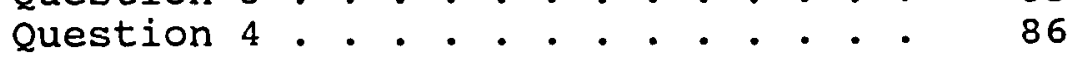


Question 5. . . . . . . . . . 87

Question 6......... . . . . 88

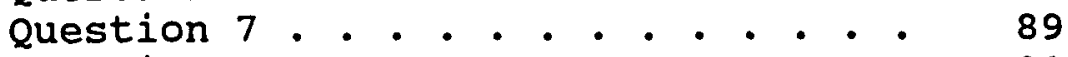

Question 8... . . . . . . . . . 91

Question 9.......... . . . . 93

Questionnaire section II . . . . . . . . 94

Parents' and Students' Attitude

towards School Work According

to Teachers' Assessment . . . . . 94

Question 1... . . . . . . . . 94

Question 2. . . . . . . . . . . 96

Question 3. . . . . . . . . . . . 97

Question 4 . . . . . . . . . . . 100

Question 5. . . . . . . . . . . 101

Question 6... . . . . . . . . 102

Question 7. . . . . . . . . . 103

Question 8. . . . . . . . . . . 104

Question 9...... . . . . . . 105

Questionnaire section III . . . . . . 106

Attitude of Parents Towards
Their Children's Education . . . . 106

Question 1... . . . . . . . . 107

Question 2....... . . . . . 108

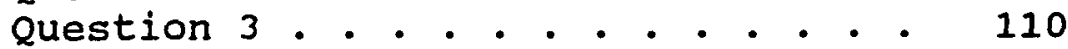

Question 4 . . . . . . . . . . . . 111

Questionnaire Section IV . . . . . . . . 113

Administrators' Perception on

Programs Needed for At-Risk

Students . . . . . . . . . . 113

I. Child Intervention . . . . . . . . 114

Question 1 . . . . . . . . . . . . . . 114

Question 2 . . . . . . . . . . . 116

Question 3 . . . . . . . . . . . . . 116

II. Parent Intervention . . . . . . . 117

Question 4... . . . . . . . . . 117

Question 5 . . . . . . . . . . . 119

Question 6 . . . . . . . . . . . . 120

III. Management . . . . . . . . . 120

Question 7 . . . . . . . . . . . . . . 120

Question 8 . . . . . . . . . . . . . 122

Question 9 . . . . . . . . . . . 122

Question 10 . . . . . . . . . . . . 123

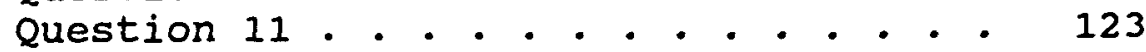

Question 12 . . . . . . . . . . . . 124

Question 13 . . . . . . . . . . . . 124

IV. Program . . . . . . . . . . . 125

Question 14 . . . . . . . . . . . . 125

Question 15 . . . . . . . . . . . . 125

Question 16 . . . . . . . . . . . 127

Question 17 . . . . . . . . . . . 127

Question 18 . . . . . . . . . . . . . 128

V. Extracurricular . . . . . . . . 128

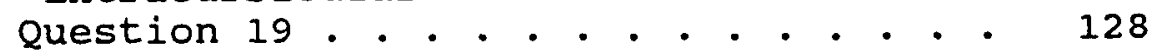




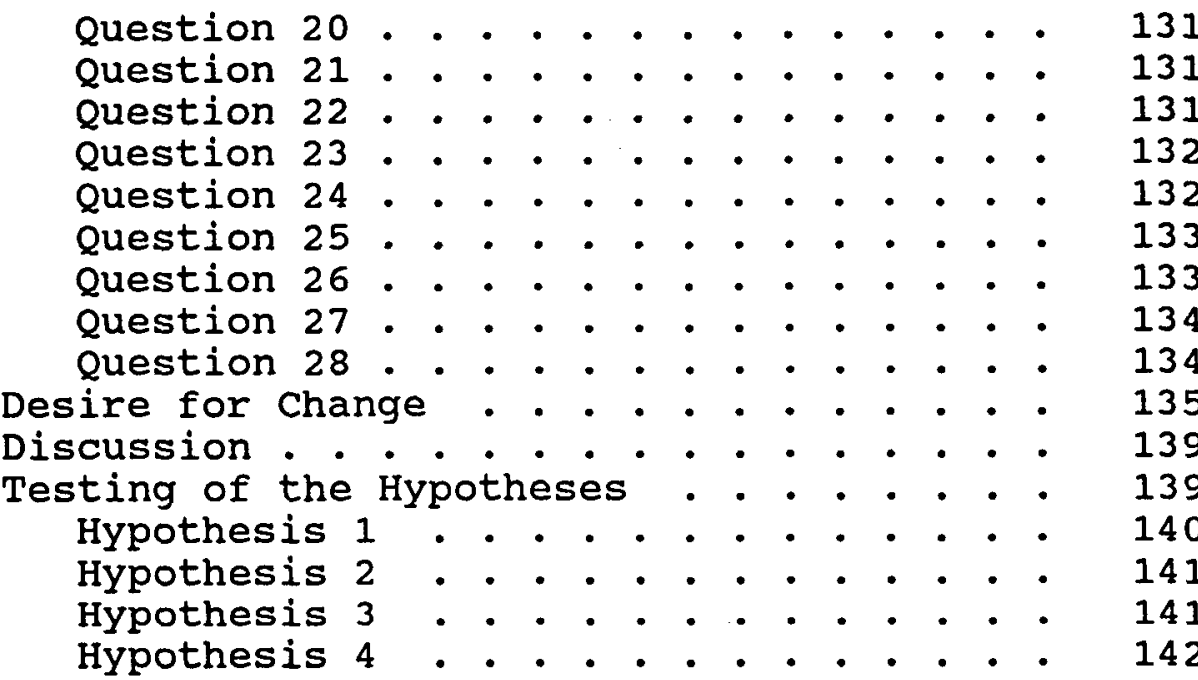

V. SUMMARY, CONCLUSIONS, AND RECOMMENDATIONS • • 144

Introduction . . . . . . . . . . . . . . 144

Statement of the Problem . . . . . . . 144

Purpose of the study . . . . . . . . . 145

Research Questions.. . . . . . . . . 145

Hypotheses . . . . . . . . . . . . . 145

Hypothesis 1 . . . . . . . . . . . . . 145

Hypothesis 2 . . . . . . . . . . . . 146

Hypothesis 3 . . . . . . . . . . . . 146

Hypothesis 4 . . . . . . . . . . . 146

Summary . . . . . . . . . . . . 146

Conclusion . . . . . . . . . . . . 147

Recommendations . . . . . . . . . . 150

General Recommendations . . . . . . 151

Recommendation for Further Study . . . 153

Overview of a Research-Based

Plan for Reform in Benton

Harbor Schools . . . . . . . . . 155

Stopstreaming: Does It Work

for Your Students? . . . . . . . 157

Summary: The Verdict Is in for

Benton Harbor Elementary Schools . . . 163

Appendix . . . . . . . . . . . . . . 165

A. QUESTIONNAIRE . . . . . . . . . . . . 166

B. CORRESPONDENCE . . . . . . . . . . . . . . 179

c. DATA AND ANALYSIS OF DATA . . . . . . . . . . 204

BIBLIOGRAPHY . . . . . . . . . . . . . . . 260

VITA . . . . . . . . . . . . . . . . 276 


\section{LIST OF TABLES}

1. "At-Risk" Educational Correlates

Present in the African American

Students in the Benton Harbor

Elementary School System . . . . . . .

2. "At-Risk" Family and Socio-Economic Correlates to Look for in the Families (Parents/Guardians) of the "At-Risk" African American Students in the Benton Harbor Elementary School

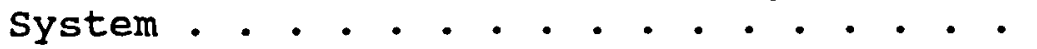

3. "At-Risk" Physical and Mental Correlates present in Most "At-Risk" Youngsters...

4. Percentage According to Four At-Risk Indicators on Five Variables . . . . . .

5. Grade Level Taught . . . . . . . . . . . 83

6. Years of Teaching Experience . . . . . . . 84

7. Years Taught in This School . . . . . . . 86

8. Level of Satisfaction . . . . . . . . . 86

9. Factors Foremost in Job Satisfaction . . . 88

10. Discipline Rated . . . . . . . . . . . 89

11. Factors for Absence of Discipline . . . . . 90

12. Student Achievement . . . . . . . . . . . 92

13. Moving to Another Teaching Position . . . . 93

14. Ethnic Background According to
Teacher's Perception . . . . . . . . 95

15. Type of Family . . . . . . . . . . . . . 96

16. Mothers' Education . . . . . . . . . 98

17. Parents' Education . . . . . . . . . 99 
18. Educational Materials . . . . . . . . 99

19. Daily TV Watching . . . . . . . . 101

20. TV supervision . . . . . . . . . 102

21. Bedtime Supervision ........... 103

22. Reading with Parents . . . . . . . . 104

23. Discussing Lessons with Someone at Home . . 105

24. Student stability ........... 106

25. Education for Freedom and Equality ..... 108

26. Education as a Vehicle ......... 109

27. Reading Skills and Mathematical Ability . . 111

28. Quality Care and Education for Infants . . . 112

29. Educational Administrators' Responses... .115

30. Educational Administrators' Responses
to Part II, Questions $4-6$...... 118

31. Educational Administrators' Responses
to Part III, Questions 7-13 ..... 121

32. Educational Administrators' Responses
to Part IV, Questions 14-18... . . 126

33. Educational Administrators' Responses

34. Difference in Desire for Change

Between Teachers, Parents, and

Administrators . . . . . . . . . . . 136

35. Teachers Desiring Change . . . . . . . 136

36. Parents Desiring Change . . . . . . . 137

37. Administrators Desiring Change . . . . . 137

38. Difference in Desire for Change between
Teachers, Parents, and Administrators . . 138 


\section{ACKNOWLEDGMENTS}

First and foremost, I thank our Heavenly Father, my God, the "ONLY GOOD MASTER" for His wonderful ways in providing for our needs. I wish to acknowledge the following people for what they have done to make this dissertation a dream come true in various ways.

Suzanne (Ravaud), my wife, who supports, encourages, loves, and helps me and is by my side in good as well as bad times.

To our lovely children, Ketty and Karyl, for their love, patience, understanding, support, and prayers.

To Dr. Bernard M. Lall, Dr. Elsie Jackson, Dr. Newton Hoilette, Dr. Jerry Thayer--dissertation chairman, committee members, and counselors respectively, for their constant help, corrections, suggestions, and giving of themselves to help me.

To all my professors and friends who have been a source of inspiration: Dr. E. Streeter, Dr. John Youngberg, Dr. W. G. A. Futcher, Dr. W. Douglas, and Dr. C. Applewhaite.

To Mrs. Janelle McCoy, executive secretary for the doctoral programs, who was a source of encouragement 
to me in my completion of this study.

To my administrators, colleagues, friends in the Benton Harbor Area Schools, and the members of the Board of Education for their constant support and encouragement:

Mr. James Rutter, Dr. Joseph A. Shurn, Dr. S. Allen, Dr. W. A. Sayegh, Mrs. Jane Strand, Mr. M. P. Newman, Mr. A. Crump, Mr. L. Gavin, Mrs. Renée Williams, Mrs. Greta Hines, Mrs. Virginia Maxwell, Ms. Lynn McAvoy, Mr. Gregory Mauchmar, Mr. Richard Garrison, Ms. Ann Kennedy, Mr. J. W. Roberts, Dr. Sherry Collins, and Ms. Inez Waddell.

To Mrs. Bonnie Proctor and Mrs. Evelyn Muffo who assisted in editing the document.

To Mrs. Joyce Campbell and Mrs. Adelaide Brackett for their excellent work, as no dissertation could be completed without top typists.

To such special friends as Mrs. Yvonne Douglas, Mr. Garford Reid, Mrs. Carolyn Walton, Mr. Jacob J. Nortey, Dr. Roland Joachim, Mr. Disciple Amertil, and Mrs. Ninon Amertil, whose words of encouragement kept me going.

To my blood brothers and sisters whose abiding confidence in me always inspired me to reach for the stars. Here I single out two who have similar faith as I: Mrs. Elinette (Honorê) Joseph, my "little mother," and Pr. Lamartine J. Honoré, my spiritual and intellectual mentor, whose example of courage and determination was my 
main and earliest source of human inspiration in life. His guidance in my early years is priceless. 
CHAPTER I

INTRODUCTION

\section{Background of the Problem}

The Benton Harbor school system has had many problems over the years, especially in dealing with youth who drop out of junior and senior high schools at an early age. It appears that a large number of students who have remained in school fall into the category of "at-risk" youth.

statistics abound on the devastating consequences of the "at-risk youth." Such consequences are evidenced in at-risk students becoming dropouts, juvenile law offenders, crime prone, pregnant, and victims of crime within the city of Benton Harbor and the surrounding areas.

\section{Area Demographics}

Benton Harbor Area Schools serve a low economic urban/rural community in Berrien county that is located in southwestern Michigan. This county lies on the primary highway system between the drug traffic centers of Chicago, Illinois, and Detroit, Michigan. This strategic location, the city of Benton Harbor and Berrien county, becomes a major staging ground for drug 
long-term depressed economy and industrial relocation have made Benton Harbor and its ethnic/cultural population fertile soil for drug abuse, which has escalated crime in the community. This has generated an unusually high percentage of at-risk youth. Smith and Nance-Nash (1989) ranked Benton Harbor the least desirable place to live in out of 300 selected U.S. cities, using such criteria as economics, crime, safety, and cost of living. Michigan public health statistics record that the persquare-mile crime rate in Benton Harbor is second only to Detroit in the state.

According to school authorities Benton Harbor contains a population of 14,707 . Forty percent (40\%), approximately 6,000 , are under the age of 20 . Thirtynine percent (39\%) of the families in the city live below the poverty level. Eighty percent ( $80 \%$ ) of all residents are on public assistance. Eighty-six percent (86\%) of the population belong to a minority group. Area infant mortality ranks high at a rate of 41.9 deaths per 1,000 live births (Williams, 1983).

The Benton Harbor Area School district serves Benton Harbor and immediate adjacent communities in a 56square-mile service area containing a population of 44,000. The school district enrolls 7,200 individuals (K-Adult Education) with a racial-ethnic population of $80 \%$ African Americans, $19 \%$ Whites, and $1 \%$ others. More than threefourths of Benton Harbor families are single-parent 
families. The school system reports an annual dropout rate of $12 \%$, and a $10 \%$ teenage pregnancy rate, reflecting 158 live births to teenage mothers in 1990 . It also reported 4,091 secondary suspensions and 957 elementary suspensions during the 1989-1990 school year. School authorities have identified 4,700 of the 6,900 K-12 students as high-risk youth. This does not include a large pool of existing drop-out residents in the community. Gang operations and crime are rampant.

Area court system records between 1988 and 1990 show a $30 \%$ increase in juvenile offenses committed by youth under age 17 . Seven percent (7\%) of all juvenile offenses in 1988 were of a violent nature. violent crimes reached $11 \%$ of juvenile offenses in 1990 . The current average age of juvenile offenders is 13.5 years. A sampling of crime records during 1990 shows a monthly pattern of Benton Harbor children and youth injured or killed by juvenile violence, much of it drug-related. Law enforcement and school officials assert that the high level of at-risk population provides a fertile ground for drug distribution. They also recognize that the majority of juvenile crimes are drug/alcohol-related. The Berrien County Forensic Drug Identification Laboratory records a $198 \%$ increase in marijuana samples submitted to it for testing between 1979 and 1989, with a $352 \%$ increase in cocaine samples submitted during the same period (Ellington, 1990). 
The 1994 Search Institute Profiles of Student Life for Attitudes and Behavior on Benton Harbor students (Williams, 1995) provides crucial data: (1) For example, alcohol use within 30 days: from January 2, 1994 to January $31,1994,14 \%$ in grade $9,26 \%$ in grade $12 ;$ cars driven after taking one or more drinks within the last 12 months, from August 1993 to July 1994: 10\% Juniors, 18\% Seniors; (3) illicit drug use index is highest for 10th-graders and 12th-graders (marijuana, cocaine, amphetamines, LSD and heroin); (4) physical abuse among 11th-graders: $27 \%$ reported physical abuse once or more; sexual abuse: $23 \%$ females and $4 \%$ males reported sexual abuse; (5) highest at-risk indicators: sexual activity, $73 \%$; contraceptive use, $33 \%$; riding in a car with someone drinking $24 \% ;$ (6) students who experience 1 or more of the 45 at-risk indicators: $81 \%$ in 9 th grade; $91 \%$ in 11 th grade; $48 \%$ in 12 th grade experienced 3 or more at-risk indicators. (See Tables 1 , 2 , and 3, for at-risk educational, socioeconomic, physical, and mental correlates.) If one of the factors was present in a student's life, that factor was assumed to be a symptom of at-riskness that might make the individual more vulnerable to other factors present in the environment. It was not assumed in previous research that these factors caused at-riskness but rather that there might be an associative relationship between one or more of the factors and at-risk behavior (Frymier, 1989). 
Both local government and school officials have drug prevention programs in place, but suffer major blocks in program implementation due to lack of funds. Most of the characteristics present in the at-risk African American students and found in their families are presented in Tables $1-3$

\section{Statement of the Problem}

It appears that the majority of the Benton Harbor youth fall into the category of "at-risk" students. They are at risk of dropping out of school, of becoming pregnant or of becoming involved in criminal action. The traditional schools have not been able to handle the problems of these students. In fact, the problems relating to these youth appear to increase with each passing year.

\section{Purpose of the study}

The purpose of this study has been to determine the concomitant educational problems facing the "at-risk" African-American students in the Benton Harbor Elementary School system and to suggest positive changes through an alternative model.

\section{Significance of the study}

This study may prove to be significant as it endeavors to open new horizons to solve the endemic, concomitant, educational problems of the at-risk African 
TABLE 1

"AT-RISK" EDUCATIONAL CORRELATES PRESENT IN THE AFRICAN AMERICAN STUDENTS IN THE BENTON HARBOR ELEMENTARY SCHOOL SYSTEM

$\begin{array}{ll}\text { Factors } & \text { Characteristic traits } \\ \text { Achievement } & \text { Poor grades with declining trend } \\ & \text { Failure of one or more grades } \\ \text { Incomplete class work } & \text { Low basic skill levels } \\ & \text { "Slow learner" with IQ 74-90 } \\ \text { Disciplinary } & \text { Frequent absenteeism, tardiness, } \\ & \text { Disruptive and rebellious behavior } \\ & \text { Low tolerance of structure } \\ \text { Alienation } & \text { Limited extracurricular involvement } \\ & \text { Lack of identification with school } \\ & \text { Loner with poor peer relationships } \\ & \text { Active dislike of school } \\ & \text { Desire for alternative learning model } \\ & \text { No perception of relevance of school } \\ & \text { Lack of a goal orientation } \\ \text { Critical Thinking } & \text { Susceptible to advice to leave school } \\ & \text { Low perceptual performance }\end{array}$

Note. From Teressa V. Staten, 1990, Bureau of Educational Services, Lansing, Michigan. 
TABLE 2

"AT-RISK" FAMILY AND SOCIO-ECONOMIC CORRELATES TO LOOK FOR IN THE FAMILIES (PARENTS/GUARDIANS) OF THE

"AT-RISK" AFRICAN AMERICAN STUDENTS IN THE

BENTON HARBOR ELEMENTARY SCHOOL SYSTEM

Factors

Family Factors

Social Factors

Economic Factors
Characteristic traits

Lack of stable support system or residence

Family history of alcohol or drug dependency

Low parent or sibling educational attainment or illiteracy

Family history of physical abuse or neglect

single parent, teenage parent or absent parents

High family density

Limited or non-English-speaking household

Poor home-to-school communications

siblings who have dropped out of school or have been involved with crime or drugs

Alcohol and drug abuse or addiction Court-related problems

Inability to relate to authority figures

Friends are frequently older dropouts outside of school

Low family income or unemployment Need or desire to work

Note. From Teressa V. Staten, 1990, Bureau of Educational Services, Lansing, Michigan. 
TABLE 3

"AT-RISK" PHYSICAL AND MENTAL CORRELATES PRESENT IN MOST "AT-RISK" YOUNGSTERS

Factors

Characteristic traits

Physical Factors

Low birth weight

Developmentally delayed, physically immature

Nutritional deficiencies

Long-term or chronic illness

Physically handicapped

Mental Factors

Destructive or violent temperament Mentally immature, susceptible, easily distracted

Lacking motivation, fear of risktaking

Hostile and unruly or passive and apathetic

Low self-concept, failure syndrome, refuse to try, easily discouraged

Note. From Teressa V. Staten, 1990, Bureau of Educational Services, Lansing, Michigan. 
American youth of Benton Harbor. It may identify educational needs of the "at-risk" African American youth of the city of Benton Harbor. It proposes to demonstrate the necessity of urgently modifying the curricula of all elementary schools of the city of Benton Harbor. The study adds to the sparse literature on educational programs for "at-risk" inner-city African American youth of America. It can be contributory to an academic master plan for the city of Benton Harbor elementary schools. Ultimately, it can be a model for the development of the U.S.A. inner-city primary schools regionally, and if necessary, even nationwide. The research has endeavored to get national experts' opinions in the areas of at-risk African American students' academic success. Such strategies gleaned will enable an examination of the viability of the proposed alternative programs for most elementary schools in Benton Harbor.

\section{Research Questions}

This study proposes to address the problem around two basic questions:

1. What are the perceived concomitant educational problems facing the African-American elementary students in Benton Harbor?

2. Is there a need for change in the Benton Harbor school system? 


\section{Null Hypotheses}

Hypothesis 1: There is no significant difference between the parents', teachers', and administrators' perceived concomitant educational problems due to teachers' burnout, lack of discipline, and low academic achievement in reading, mathematics, and science.

Hypothesis 2: There is no significant difference between parents and the teachers of Benton Harbor elementary schools with respect to the need for change within the school system.

Hypothesis 3: There is no significant difference between the parents and administrators of Benton Harbor elementary schools with respect to the need for change within the school system.

Hypothesis 4: There is no significant difference between the teachers and administrators of Benton Harbor elementary schools with respect to the need for change within the school system.

\section{Definition of Terms}

The terms used in this study have been defined as follows :

At-risk youth: Children whose poverty, poor nutrition, and lack of health care and family backing contribute to a never-ending cycle of learning problems, and failure in the early grades (Staten, 1990).

Academic academy: Special primary school often 
termed "school without failure" where students are taught who are "at risk" of dropping out of school and are not developing the basic technical and social skills required to effectively interact in society today. In that particular setting the teaching is geared toward successful outcomes for the learners in order to raise their self-esteem and self-confidence (Glasser, 1968).

\section{Elementary school system constituency of Benton}

Harbor: The total population $(44,000)$ of the city of Benton Harbor with its elementary school system.

Benton Harbor primary school system: A subsidiary of the Benton Harbor area school district that consists of 15 elementary schools. Among them are three magnet schools and an academic academy.

Miseducation: Education whereby the oppressed finds in the oppressor his/her model of 'manhood' (Woodson, 1933).

White studies: System of intellectual legitimacy that defines the activities and experiences of white Western people as the universal yardstick of human existence (Turner, 1971).

Black studies: Studies that focus positively on Black history, Black culture folklore, and that enhance Black children's self-esteem and identity.

Concomitant: Factors that accompany or are collaterally connected with something else, such as the main issue being addressed, an incident, or another fact. 
Liberation: Education that has a consciousnessraising function for African American people, instructing them concerning the following realities: where they came from, where they are going, who they were, who they are now, who they will be, who the unidentified adversary is, what the unidentified adversary is doing to them, what to struggle for, and what form the struggle must take (Hale, 1984, p. 6).

Ego Dystonic Poverty: Disharmony with a positive view of self (Booker \& Gary, 1995).

Sociogenic brain damage: Damage done to the maturation of the brain by depriving it of the social stimulation necessary for the proper development of those neural interrelations essential for successful mental functioning (Kunjufu, 1983; Kohn, 1993; Montagu, 1974; Rosenzweig, 1971; Yannet, 1952).

Cultural monism: The biased process of using Anglo-saxon cultural production and values as standards for measuring all other people, cultural production, and values (Welsing, 1991).

Psychoeducational: Related to the mind impairment which makes the process of education difficult to occur.

For all practical purposes in this study the terms "little satisfaction" and "so-so" equate to "not satisfied." 
Delimitations of the study

This study focuses on the city of Benton Harbor's primary school system and its constituency. It deals mainly with the $80 \%$ of the primary school population who are African-Americans. Its findings may not be necessarily applicable to other primary school systems operated by other inner-city school boards around this nation.

\section{Basic Assumptions}

1. Every youth regardless of his/her skin color deserves, in American democracy, to receive an education that will be a preparation for life in society.

2. A democratic educational system should allow each individual to become all that he/she is capable of becoming.

3. There should be in America equalization of educational opportunities by strengthening the "family unit."

4. In all lines of work designed to keep America competitive in the world market, there is a vast field to be occupied; and, more than ever before, the task is to prepare workers from all sectors of the American children (rich, poor, majority, and minority groups) including all shades of skin. Education, then, should not be elitist or racially biased.

5. All education should prepare the student for service to one's fellow beings in the community and ultimately to the nation. 
6. Keeping students in school requires addressing the broad range of problems facing young people.

7. All educators--teachers, administrators, student services staff, and others, including the community--must work cooperatively to reach the goal of school dropout prevention.

8. A planned, comprehensive approach creates a successful school dropout prevention effort.

\section{Summary}

Currently, there is only one alternate school available in the city of Benton Harbor. It is known as an academic academy. In that school, significant programs in increased learning by the students has been shown. However, these students have to return to the mainstream classrooms across the district with varied levels of failures. Were they allowed to stay in this kind of learning up to their 8 th grade their subsequent success in high school years would have been assured. The presence of the correlates of "at-risk" factors (pp. 5-7) in a youngster's life does not necessarily spell doom for that young person. "At-risk" youngsters can succeed. The programs and policies that educators choose to pursue can make a difference.

The alternative program offered by the academic academy operates in the spirit of the school Development Model, utilizing many of the sound educational ideas as 
mandated by Judge Hillman in the Desegregation order of May 1981. As part of that program, the district has established an achievement component for students in the lower elementary grades that provides innovation in curriculum implementation and in interpersonal relationships within the classroom. A similar program extended to all the primary schools of Benton Harbor may be the solution for their students' learning difficulties.

\section{Organization of the Dissertation}

This study has been divided into five chapters as follows:

Chapter 1 constitutes the introduction to the dissertation. It includes a background to the problem, a statement of the problem, the purpose of the study, the significance of the study, research questions, hypotheses, definition of terms, delimitation of the study, basic assumptions, and organization of the dissertation.

Chapter 2 provides a review of the related literature on the relevance of a modified approach in order to positively affect the $80 \%$ at-risk African American students enrolled in the primary schools of Benton Harbor.

Chapter 3 provides the methodology used in the development of the study. This includes a statement on the type of research, population and sample, research 
instruments, methods of statistical analyses used and the procedure followed.

Chapter 4 deals with the results of the study.

It presents the feedback necessary for establishing a model program.

Chapter 5 constitutes the summary, conclusions, and recommendations arising out of the study. 
CHAPTER II

REVIEW OF THE LITERATURE

\section{Philosophical Preamble}

The philosophy that undergirded this study was the viability of development and administration of a modifiedtype program for all the elementary schools of the city of Benton Harbor. It has been assessed by the school authorities that $80 \%$ of the African American youth of that city are "at-risk" and need a good 6-year elementary education. Nationwide, more native Americans (42\%), Blacks (40\%), and Hispanics $(38 \%)$ were at risk than White $(20 \%)$ or Asian (20\%) children. Students in certain schools and communities were more at risk than students in other schools and communities (Frymier, 1989).

Howe and Edelman (1985) and Edelman (1993) claim that primary education must be available to all. It must be neither elitist nor racist. It should beckon the student who is not high-school bound as well as those who have that potential. It should open its door to, and make provisions for, the more intellectually able as well as those who are more vocationally inclined (p. 7). White (1952) concludes her argument against barriers evident in education thus: "Let every child, then, receive an 
education for the highest service" (pp. 266, 267).

In short, the philosophical underpinning of the study is the concept that the major raison d'être of an appropriate and competitive primary school system in the city of Benton Harbor is to facilitate educational opportunity for all.

Hale-Benson (1986) contends that an educational philosophy with the following three components seems to be ideal for a curriculum for African American children:

1. Political/cultural (ideology)

2. Pedagogical relevance (method)

3. Academic rigor (content) (p. 18).

An alternative curricular model for African

American children must have at its foundation an accurate historical and political analysis of the situation of Black people in America and in the world (p. 152).

In the article "Save the Children," Atkinson and Horde (1984) state:

Every educational system functions to perpetuate the larger society by acculturating its young into that order; and the purpose of American colonial education system is to maintain this societal structure. Its claims of individual freedom, cultural pluralism and world democratization obscure its ideologies of elitism, cultural monism and world Americanization; and African American children are the acculturated victims. (p. 184)

These structural realities contribute to the academic and cultural problems of African American students--educated to believe in individual freedom and that one is thus responsible for one's own success or 
failure, although they are not adequately equipped to succeed. African American students often question their own intelligence when they do not succeed in school. Thus their self-esteem is shattered very early in life (Mingle \& Rodriguez, 1990). This study attempts to suggest an alternative educational program that may aid in truly preventing these African American children from losing confidence in their ability to succeed.

\section{Organization of the Review}

This chapter, therefore, has been organized around a review of the related literature on the U.S. academic academy. I have reviewed the literature on successfully educating African American children. This chapter gives a definition, traces the historical development, discusses the purpose, and describes the nature of the problem and the raison d'être of identifying it. The review of the related literature has indicated how to work effectively with "at-risk" African American learners using research strategies for successful outcomes. This review has ultimately explored what constitutes a positive learning climate for the "at-risk" African American children.

\section{The U.S. Academic Academy}

\section{Definition}

A viable model, proposed through this study by the U.S. Academic Academy, is the one defined by the 1988 Carnegie Commission on Primary Education in its report 
entitled: "The Comprehensive Public Six-Year Elementary School Program Which offers Academic, General, Remedial, and Complete Mastery of the Three R's" (p. 7). The 1982 edition of the Handbook of Data and Definitions in Primary Education gave a similar, if not more detailed, definition (Holt, 1964):

Academic Academy--A six-year institution of primary education generally termed school "without failure," public, offering instruction adapted in content, level, and schedule, to the needs of the community students in which it is located. In it, learning occurs regardless of "at risk barriers." (p. 29)

Historical Development of U.S. Academic Academy

The major themes that guide the curricula of the present-day academic academy as highlighted in the definitions above were envisioned early in the 20 th century. Staten (1990) states:

Early in the [20th] century, Alex Lange and Leonard Koos envisioned a primary school with a transfer function similar to the European type that would relieve the secondary school of its lower division offerings, with a vocationally-oriented education function that would satisfy the societal needs for manpower and the individual need for a job, one providing basic general education so that informed citizens could make intelligent choices about their own life and the life of their community, and with a function of helping the individual to grow in his/her own right with his/her self-esteem intact. (p. 142)

This first-class basic primary education was designed to empower the youth for any further necessary study.

But the historical roots and necessities of the academic academy movement can be traced further back in time. Furthermore, the movement has "multiple roots" 
(Carnegie Commission on Primary Education, 1988, p. 17). It is in these very historical roots and necessities that an understanding of the special place of the academic academy in the American inner-city primary school education can be gleaned.

According to Phlegar and Rose (1988), the first major events that had profound effects on American innercity primary education are particularly eloquent for the contemporary need of a modified academic academy-type program for all the elementary schools of the inner cities of America. They become clear in the comparison of the problems of today in our schools with those of the 1940 s (Staten, 1990, p. 145).

In the 1940s, teachers experienced the following problems:

1. talking out of turn

2. chewing gum

3. making needless noise

4. running in the halis

5. getting out of turn in line

6. wearing inappropriate clothing

7. not putting paper in waste baskets.

Today, problems consist of:

1. drug abuse

2. alcohol abuse

3. suicide

4. rape 
5. robbery

6. assault/weapons

7. pregnancy.

In the needs assessment for a larger academic academy for the city of Benton Harbor, Ellington (1990) asserts: The Academic Academy was established in the fall of 1988 to address the academic and social needs of under-achieving primary students in the Benton Harbor area schools. This "at-risk" prevention program served 250 second- and third-grade students who were experiencing academic failure. Many gains were made during this 2-year period primarily due to:

1. caring and effective teaching staff

2. reduced class sizes

3. paraprofessional assistance

4. maximized learning opportunities

5. high level of expectations for staff and students

6. orderly and structured learning environment

7. opportunities to use hands-on materials

8. integrated curriculum (Ellington, 1990).

orr (1987) goes on to say:

Eclectic, opportunistic yet pleasantly rigorous, the academic academy has its force and meaning rooted in the urgent needs of inner-city life, in the process of change and in the faith that among the ways to better life none is more important than education for all. (p. 33)

Commenting on the recent emergence of the 
academic academy and its uniqueness in the city of Benton Harbor, Ellington (1990) says: These 250 second- and third-grade students are now better prepared to return to general classrooms throughout the district and will strive harder to achieve because they have experienced academic success.

However, Benton Harbor area school district reports indicate that 323 students need this program since they are slated for retention and/or are eligible for special federal assistance (Chapter I) services. Intervention programs are still greatly needed to reduce the failures in our educational system.

speaking of the widespread and fast-growing academic academy movement in the American inner city, Staten (1990) surmises that

without clearly understood and expressed aims which fit the pattern of American life, no new educational movement can long survive. In establishing programs that effectively address the needs of our African American youth, student outcomes, or effectiveness, are primarily demonstrated by indicators of student learning. Effective schools utilize a well-developed and quite specific curriculum continuum; a management system parallels this continuum. Goals and objectives are detailed, and grade-level expectations are clear. ( $p$. 12)

$\frac{\text { The Literature on Educating African }}{\text { American Children Successfully }}$

In the Introduction of Developing Positive SelfImages and Discipline in African American students by

Kunjufu (1983), Na' im Akbar writes:

The problem of educating African-American 
children in the American context is as old as the presence of African Americans in this setting. The question is also as complex as the experience of the African American. Notables such as Dr. W. E. B. Dubois, Bishop Henry M. Turner, Dr. Carter G. Woodson, Marcus Garvey, Elijah Muhammad, Dr. Martin Luther King, Jr., and Malcolm X have all addressed the issue of education as being one of fundamental importance in the progress of African Americans. The example of Booker $T$. Washington, Mary McCleod Bethune, Dr. Benjamin Mays, and many others are legendary in their commitment to developing institutions for the express purpose of educating African American youth. Frankly, African American history in America is completely inseparable from the attempt to handle the challenge of African American education in this setting of historical oppression and thwarted opportunity. (p. 201)

Many contemporary African American scholars have continued to address this same question of educating the African American child. The inescapable reality is, and always has been--for the African, West Indian, and others--that the liberation of African Americans must of necessity depend upon an effective education. I emphasize "effective" because, says Robert Williams (1981), so much of our education has been virtually useless in accomplishing the objective of liberation. The process of "miseducation" as described by Dr. Carter G. Woodson in 1933 has continued to impede our progress as an educated people. Dr. Woodson's conclusion that the majority of educated African Americans were all but "worthless in the uplift of their people" remains an issue of deadly accuracy. His analysis was that the seat of the trouble was in what African Americans were being taught. According to Diop (1985), the ancient African 
function of education was to do no less than to develop positive self-images and discipline for the adherents of the educational system. The assumption that existed in those times of greater illumination than these was that the human being was already equipped with the tools of enlightenment. The word education did not assume that critical knowledge had to be imposed from without. As the word itself implies, it was to be educed from within. Even today, says Sertima (1989), in Africa or in the African diaspora the method for educing knowledge is done through the cultivation of an inner discipline that brings these resources to the fore. In Ancient Kemit (called Egypt) the original teachers cultivated selfesteem or a positive self-knowledge by fostering an awareness of one's historical and/or mythological origins. This approach gave insights into the resources that each individual contained by virtue of his or her divine and genetic legacy (Newsome, 1990).

As says Akbar (1981), the secret for such enlightenment was the ancient edict of "Man know thyself," inscribed by these ancient scholars on the portals of their temples (which were simultaneously universities). The positive self-image emerged from the cultivation of self-knowledge. The application of the knowledge that was obtained was manifested through self-discipline. So the things most critical in an educational system are to know oneself, and to know how to manage oneself. 
According to Curwood (1983), this persisting deficiency in the education of African Americans has created the great difficulties of re-ascendancy that they have experienced as a people. Dr. Woodson's identification of this problem as existing in what Blacks were taught seems to still be a quite relevant assessment of our educational difficulties in America.

This problem described so accurately by Dr. Woodson over 50 years ago is even more of a problem as we are about to enter the 21 st century and find African American youth being not only "miseducated" but actually "de-educated." De-educated, says Kunjufu (1983), means that the African American children in the inner cities are being systematically excluded from the educational system and/or they are being systematically destroyed within that system. This is an issue of great complexity and magnitude, which extends far beyond the scope of this study.

This review of literature organizes its approach to African American education around the issue of the importance of positive self-images and discipline as a prerequisite for the effective education of African American children. The major hindrances to effective African American education according to Kunjufu (1983), Hale (1982), Postman (1982), Jones (1982), Burns (1981), Morgan (1980), Karenga (1982), and Vasiloff (1983) are consistent with the problems of American education in 
general. These authors attribute at least the greatest part of the African American educational problem to the "banking concept" in education. They criticize the "certainty principle" and rote learning, and lay several other major criticisms that non-Black writers have advanced about contemporary education in general. They all address the specific needs of the African American child within this context. They emphasize the unique cultural and learning styles of African American children and the need for the curriculum to take those styles into account. They draw upon the contemporary issues of declining discipline within the educational and home environments. They also demonstrate the unique meaning of this problem for African American children. Suggested positive changes in the learning difficulties observed among the African American highrisk students in Benton Harbor elementary schools are based on these pertinent considerations.

\section{Program Design}

Consensus has been reached concerning the nature of the program of the comprehensive academic academy. Nedsker and Tillery (1987) claim that it "can best be summed up as a program for all" (p. 27).

The essence of the nature of the successful innercity academic program has already been described in this review of the literature under the subheadings definition, 
historical development, and purposes. It should suffice, therefore, to make a summary statement at this juncture. Howe and Edelman (1985) tersely summarized the nature of the successful inner-city academic programs thus:

The program is designed to satisfy the educational needs of the most diverse population of youth. It is strongly believed and verified that the major factor contributing to positive student outcomes is a very positive learning climate that is consciously created and maintained. A positive learning climate is an aggregate of shared positive perceptions, values, and beliefs, combined with appropriate supportive actions.

\section{Components of a Positive Learning climate for African American Children}

Some specific attributes of a positive learning climate for African American children according to Akbar (1981) are:

1. A clear school mission emphasizing competence and pride in historical ascendancy

2. A strong parental and community support toward written and accepted self-disciplined goals

3. A safe and orderly environment created by a strong school administration (In this secure haven they must daily learn who they are and the general consequences of being at-risk of dropping out of school.)

4. A climate conducive to learning fostered by the school personnel 
5. High expectations and demand for student and teacher performance

6. A good staff morale

7. High parent/teacher expectations

8. Positive self-images and discipline fostered by parents/teachers.

According to Diener (1986):

In developing effective alternative program models for remediation, strong school leaders provide:

1. coordination;

2. parent involvement;

3. professional development;

4. evaluation;

5. strong leadership;

6. continuous progress programs;

7. individualized instruction; and

8. cooperative learning. (p. 46)

According to Teressa V. Staten, Associate

Superintendent, Bureau of Educational Services, Michigan Department of Education (1990), these categories address the "at-risk" problem in broad terms. These lists may be used as a starting point--a checklist for identifying strategies for change. In establishing programs that effectively address the needs of our African American youth "at-risk," the processes will accomplish the following for an effective program:

1. Provide direction for a good life in American society

2. Promote instructional improvement in re-ascendancy 
3. Sustain and improve the learning climate

4. Develop positive self-images and discipline

5. Deepen the knowledge of oneself and manage

that self.

\section{overview of Alternative Education}

No educational program meets all the needs of all

students. Yet for years, American public education has attempted the impossible--to teach every child in the same way at the same time, and at the same pace. Public schools cater to those who learn best in traditional academic programs at the expense of those who need different learning experiences (Beck, 1991). There is an awareness by the public and the profession that schools are not responsive to the needs of some students--the potential dropout, the ethnically diverse, and the poor. One response to these concerns is to search for alternatives--alternative curricula, alternative modes of instruction, and alternative organizational structures. The need for a plurality of modes of education to meet the needs of our diverse population has never been greater. The development of optional alternatives can provide choices for students, parents, and teachers in every community (Boschee, 1989).

\section{Alternative Education Defined}

since the concept of alternative education is based on the premise that students respond differently to 
a variety of learning environments, no standard definition for alternative education exists. However, it can be defined as an educational program or school designed to provide learning experiences which meet student needs in a positive environment using strategies that may be more structured or less structured than traditional educational programs. Alternative education is a viable means for revitalizing the entire structure of America's public education. Although most often afforded to marginal students and potential dropouts, these programs and schools can also meet the needs and interests of average or above average students who can function in traditional programs but might receive greater benefits in a non-traditional program (Conrath, 1989).

\section{Educational Potential}

According to Elam and Gallup (1990), alternative education programs and schools are not intended to replace traditional schools, but would complement them in the following ways:

1. Alternative education is responsive to the needs of students whose needs are not being met by the existing program.

2. Alternative education provides a structure for learning more about which schools meet the needs of students with different learning styles.

3. Alternative education encourages traditional 
schools to view themselves more critically.

4. Alternative education provides a vehicle for community involvement in the educational process, through initial dialogue within the community on the need for optional alternatives, through those families who must choose among the optional alternative schools, and through the involvement of community members in the alternative school.

5. Alternative education provides a mechanism for continuous change and constant adaptation.

6. Alternative education provides opportunities for exploring, designing, and developing a broader array of learning facilities.

7. Alternative education provides benefits that accrue from providing educational choice within the community.

Successful Alternative Education Programs

According to Cohen (1989): successful alternative education programs exhibit the following characteristics:

1. Proactive rather than reactive. Programs are proactive rather than reactive, focusing on causes instead of symptoms in order to provide early interventions that may prevent students from becoming disruptive, failing, losing interest, or dropping out.

2. Element of choice. Alternative education has an element of choice for students. 
3. Small school size and low student-adult ratios. Reduced enrollment and limited class size encourage students to form closer ties with peers and teachers. Small-scale schools with low student-adult ratios provide minimal, necessary conditions for more intimate interactions between teachers and learners. They are more conducive to a sense of community, where individual needs can be recognized and immediately administered to. The individual attention provided in such settings may also contribute to fostering the selfesteem of students; which is not feasible in the larger, more impersonal, conventional school (Arnove \& strout, 1980, p. 5).

\section{Individualized teaching strategies.}

Alternative education commonly recognizes the need to tailor materials and pace to student needs and to provide personalized reward systems. Individualized instruction addresses individual levels of students and allows them to progress at their own rates. In doing so, it seeks to increase the proportion of successful learning experiences and to raise students' self-confidence. These programs may include learning contracts, token economies, or point systems that reward academic and behavioral progress (Richardson, 1988).

5. Interrelated curriculum. The curriculum is organized so topics relate to each other rather than being presented as isolated and unconnected. Students 
have the opportunity to follow the basic curriculum and not lose credits if they are enrolled in an alternative program (Cavazos, 1989).

6. Techniques designed to improve self-concept. Low self-esteem is the predominant characteristic of dropouts, delinquents, and disruptive students. Successful learning situations in a personalized environment are instrumental in improving self-esteem, thereby positively influencing student approaches to social interactions, reducing absenteeism, decreasing rates of violence and vandalism, and improving students' overall attitudes toward school and adults (Sklarz, 1989).

The self-image of alternative school students appears to improve, especially for those who have not done well in traditional schools. Alternative school students tend to develop better attitudes toward school because they have had an opportunity to experience educational success. Students seem to have an increased sense of control over their destinies, feel more secure, and have a stronger self-identity. More positive attitudes tend to be demonstrated in higher attendance rates and less vandalism and violence in school (Arnove \& Strout, 1980, p. 16).

7. Capable, caring, and involved teachers. Teachers play an important role in the development of positive alternative education programs. Educators with 
a genuine interest in students tend to devote more time and energy to teaching and nurturing students than is required. While they may bring a variety of personal characteristics and backgrounds to a program, such teachers usually exhibit strong classroom management skills, a willingness to relate to students in nonauthoritative ways, and a desire to include their students in program decisions. Other noted qualities are patience, determination, high tolerance for problem behavior, flexibility, interest in alternative instructional techniques, and a desire to help students work out problems (Swanson, 1989).

8. Strong, flexible leadership. A primary difference between successful and unsuccessful alternative education programs is the principal's leadership and flexibility. Crucial qualities include personal commitment to program goals, fairness, consistency, and the ability to communicate. Arnove and strout (1980) stated:

At the level of individual schools, leadership is a critical variable. Without exception, successful alternative programs were headed by a single individual who had a vision of what a more humane and effective school could be and who provided the philosophical underpinnings, recruited the appropriate staff, structured a consistent learning environment, and communicated the school's mission to different constituencies. (p. 7)

9. Special training. Teachers and staff provide activities that motivate student learning and assure opportunity for real and frequent success through achievement (Briggs, 1981). 
10. Intensive counseling and diagnostic

services. Two integral elements of alternative education programs are counseling and diagnostic services. Individual, group, and family counseling sessions help students identify, analyze, and accept responsibility for their behavior. Peer counseling is effective in reducing violent conflicts among students and in promoting selfreliance and accountability. Program personnel stress the need for a well-developed system of diagnostic and support services. An individual learning program must have, as its basis, the accurate diagnosis of emotional and physical handicaps. Most teachers and counselors attempt to identify these impediments, along with health problems or skill deficiencies (Decker \& Decker, 1988).

11. Accelerated learning. Accelerated learning strategies stress the importance of moving away from remedial models of teaching at-risk students to approaches which accelerate student learning. Instead of dwelling on student deficiencies and previous mistakes, the concept of accelerated learning promotes maintaining an upbeat and positive environment that builds on the strengths of educationally disadvantaged students to bring them up to grade level (Rogers, 1983).

12. Collaborative efforts. Alternative programs must have support not only within the school system but from the collaborative efforts between the school and the community. According to Boschee (1989), areas of 
collaboration include health care services, income support, social services for families, tutorial and remedial help, before-and-after school care, improved parental literacy and involvement, linkage between employment and education, and attendance policies that seek to retain rather than exclude. For collaborative efforts to achieve success, all agencies involved must have a genuine commitment of their human and financial resources.

13. Flexibility. Alternative programs provide students greater flexibility than traditional educational programs. Evening schools, extended-day, and extendedyear programs offer flexibility to those who require additional credits to graduate, former dropouts seeking a GED or an eighth-grade certificate or a high-school diploma; those who left traditional programs because of pregnancy, parenthood, delinquency, or attendance problems; or those who desire to continue their education while working. Flexibility can take the form of special courses or programs, schools-within-a-school or separate schools (Nathan, 1989).

\section{$\frac{\text { An "At-Risk" Learner's Incompatible }}{\text { Curriculum }}$}

According to Hanson, Dewing, and Silver (1991), the $\mathrm{K}-12$ population is primarily extroverted (E), sensing (S), half-thinking ( $T$ ) and half-feeling (F), and more impulsive/active (A) than reflective (R). The overall 
profile E-S-T/F-A characterizes specifically the K-8 inner-city public school population. This is because all the at-risk correlates (Tables 1-3) are present in this younger group (Hanson et al., 1991).

The public school curriculum on the $\mathrm{K}-8$ levels tends to emphasize the introverted (I), sensing (S), thinking ( $T$ ), and active (A) profile, i.e., ISTA. This means its teaching methods emphasize quick, correct answers as a result of drill, practice, and memory work. This emphasis tends to overlook and therefore negate the extroverted and feeling functions of those youngsters. In short, this $\mathrm{K}-8$ approach is incompatible with $70 \%$ of the student population (Hanson et al., 1991). This means the curriculum is compatible with the natural learning strengths of only $30 \%$ of the normal population. In the city of Benton Harbor, keeping in mind the presence of all "at-risk" correlates (Tables 1-3)), this curriculum is compatible with the natural learning strengths of perhaps only $10 \%$ of the normal $\mathrm{K}-8$ population.

What does an African American "at-risk" learner look like?

$$
\frac{\text { The Profiles of the "At-Risk" Learners-- }}{\text { A Summary of a Jungian-Based Style }}
$$

Current research (Hanson \& Dewing, 1990) identifies two dominant profiles that represent the 
majority of the "at-risk" populations. There were 1,056 boys and 856 girls in the population.

From this at-risk group two main profiles have been determined. The two "at-risk" profiles are (1) ESFA: extroverted (E), sensing (S), feeling (F), active (A), and to a lesser extent, (2) NFR: intuitive (N), feeling (F), reflectives (R). The overlapping function is the learner's dependence on feeling. Also, out of the 1,912 student population (Hanson \& Dewing, 1990), the students' feeling (F) dependency was identified as the major indicator of present or future difficulty. These data also correlate positively with other Jungian-based style research from Hanson and Silver (1990) as summarized in Table 4.

\section{TABLE 4}

PERCENTAGE ACCORDING TO FOUR AT-RISK INDICATORS ON FIVE VARIABLES

\begin{tabular}{|l|c|c|c|c|}
\hline \multicolumn{1}{|c|}{ Variable } & NT & ST & NF & SF \\
\hline 1. Poor academic standing & 12.9 & 43.4 & 57.7 & 86.0 \\
2. Teacher-student strained \\
$\begin{array}{l}\text { relationship } \\
\text { 3. Student negative attitude }\end{array}$ & 12.3 & 31.3 & 75.8 & 80.5 \\
4. Student verbal involvement & 11.9 & 42.2 & 60.0 & 71.8 \\
5. Teacher estimation of & 9.8 & 75.5 & 81.5 \\
\hline degree of at-risk & 9.9 & 20.8 & 65.8 & 81.5 \\
\hline
\end{tabular}

Note. $N T=$ Intuitive half-thinking; ST = Sensing half- thinking; NF = Intuitive feeling; $S F=$ sensing feeling. This table expresses the percentage of "at-risk" students per indicator from the research of J. R. Hanson and T. Dewing (1990). 


\section{"At-Risk" Learners' Strategies for Successful outcomes}

1. The children's school experience must begin early, at least in pre-kindergarten, for the inability to speak common English, which afflicts so many African American children of the ghettos, can be overcome only by catching them very young (Oakes, 1981).

2. The "at-risk" children must be taught in small classes--not more than 15 in pre-kindergarten and kindergarten, not more than 22 or so in grades $1-6$. otherwise, teaching will stop, and keeping order will become the sole aim. Most of the children who live in the low-income inner-city families come from homes wholly unoriented toward learning and books. Gaining and holding these students' learning attention is therefore difficult. Only reduced classes permit good or average teachers to accomplish this (Ross et al., 1991).

\section{Backup teachers are needed. One extra}

teacher for each three or four classes is needed so that laggards can be promptly gathered into still smaller classes for more concentrated work (Abu-Saad, 1991; Higbee \& Dwinell, 1990; Midkiff et al., 1991).

4. All the obvious "extras" in the way of remedial reading and health and psychiatric care must be provided. These are, in fact, the added principal features of the MORE EFFECTIVE SCHOOLS (MES) program that has been under way in New York City for more than 6 
years. Most of the MES children have shown improvement, and those children who have begun in pre-kindergarten and continued from there are actually performing, on average, at grade level or above. These results mean that these children are performing as well as white middle-class children. This is a real victory over that terrible educational lag that is the curse of America's African American minority (Chachere \& Johnston, 1982; Payne, 1984; Ross et al., 1990, 1991; Schulz \& Bravi, 1986).

\section{Reaching "Unreachable" Students}

In the long overdue and necessary war to improve American education, combating truancy in public schools is the first engagement for the community and the state in a combined effort (Brown, 1983).

Rohrman (1996) examines the causes and results of truancy and offers strategies for prevention. Keeping young people in school, he states, has become one of our most perplexing challenges.

For the last twelve years, Americans have ranked "pupil lack of interest/truancy" as one of the top ten problems facing schools. In some cities, the daily absence rate can be as high as $30 \%$. In New York City alone, more than one-third of all high school students are chronically absent (Brown, 1983).

Truancy is not merely a modern dilemma. As early as 1872, the problem of "early school leavers" was 
causing concern for school officials. In 1884, only onethird of the students required to attend public school actually did so. In 1933, more than two-thirds of all school absences were non-illness related (Levine, 1984). Truancy has serious repercussions for a community. It is linked to high daytime burglary rates, auto theft rates, and vandalism. Truancy also has significant consequences for the student. Compared to regular attenders, chronic truants receive lower grades and show less than expected learning gains. Adults who were truants as children often must cope with illiteracy, social alienation, poverty, and political powerlessness. Truancy has been linked with adolescent delinquency and in a study of prison inmates, $89 \%$ had a history of school truancy (Englander, 1986).

According to American educators' perspective truancy can be traced to four causes: an unsupportive school environment, lack of community support, chaotic family life, and personal deficits. These causes are also similar factors leading to the same results in advanced or emerging industrialized nations of Asia and Europe. However the laissez-faire philosophy of American states and federal government manifested toward these youngsters on the grounds of freedom and democracy is considered as weakness and lack of foresight by those foreign industrialized nations. Truancy in France is prosecuted as a crime similar to selling drugs in the 
United states. During the school hours any minor vagabonding in the streets or the stores will be arrested and prosecuted. The youngsters' duty is to be at school, that is the law of the land (Michaels, 1984).

\section{Summary}

Truancy is one of America's toughest social

problems. The constant practice of truancy puts close to $35 \%$ of the nation's young people "at-risk" and almost beyond the educational system's ability to help. But most of America's industrial competitors have reduced truancy and what they have learned and done offers hope that many "unreachable" students can indeed be reached and educated (Simmons, 1994).

\section{The Struggle to Improve American \\ Education}

The same result of a financial burden to society as a whole is seen wherever the student is not able to ultimately cope with the increasing complexity of the work demands. Given the current "war on drugs," Hass (1996) finds it curious that the American nation is not also waging a "war on ignorance." The enemies, he warns, are equally dangerous.

The young inner-city "at risk" student sees every day several aspects and even casualties of the "war on drugs." Excellence in education is certainly elusive. 
Eight years after the publication of A Nation At Risk, this youngster still cannot point in pride to significant nationwide gains (Levine, 1984).

In the inner-city classroom, every teacher faces the grading dilemma. The public pressure for measurable results argues for a sharply focused emphasis on mastery of course content and a grade that indicates the degree of that mastery. On the other hand, a body of professional opinion exists that advocates manipulating grades and other rewards to enhance students' self-esteem as a way to encourage future achievement (Daniel, 1995; Dix, 1994; Johnson, 1987).

Furthermore, studies indicate that students in more successful foreign school systems tend to attribute their success to hard work, while American youngsters, especially African-Americans, are more inclined to believe in fate, than to argue for grading practices that reward effort (National Assessment of Educational Progress, 1994).

Writing in the Washington Post (June 1994), Dean Lester Thurow of MIT's Alfred P. Sloan School of Management observed that

the French have their (high school) baccalaureate examination. No student can be admitted in a French university without successfully passing it. After three years of unsuccessful attempts the student is declared unfit for university studies. The English have their $A$ and $O$ levels, the Japanese their examination system, the Germans theirs which all work on the 
same principle as the French. Actually, the Americans are confused about their educational goals. If a society will not clearly say what it wants from its schools, it won't get any clear performance. (p. 39)

Education of the "at-risk" students is a longrange process, and the epitome of delayed gratification. Huxley (1992) wrote that

perhaps the most valuable result of all education is the ability to make yourself do the things you have to do, when they ought to be done, whether you like it or not. It is the first lesson that ought to be learned . . and it is probably the last lesson (learned) thoroughly. (p. 56)

Influential voices in business, government, and education have agreed that we face a crisis that can only be solved by a commitment on the scale of the Marshall Plan, the interstate highway system, or the manned lunar landing project (National Assessment of Educational Progress, 1994).

The increasing economic competition from Asia and Europe is likely to force either action or surrender. As Americans are not a people that surrender easily though they often defer action until the last minute and therefore find it more costly (Dodd, 1993) they will eventually wage this long overdue war on ignorance.

Summary

It is truly curious, given the current war on drugs, that no one speaks of the war on ignorance. Surely these enemies are equally dangerous. Perhaps the specific nature of schooling does not capture the 
imagination so aggressively. The war on ignorance is a quiet war; the sounds of battle are the bubbling of testtubes and the squeaking of chalk. Perhaps the sheer size of the task is daunting, and the cost of victory surely will be high (Eastwold, 1989).

Oscar wilde remarked about a man who knew "the price of everything and the value of nothing." But Harvard University President Derek Bok may have said it best: "If you think education is expensive, try ignorance." Americans cannot afford any longer to defer the payment of the accrued debt of ignorance (Levine, $1984)$.

\section{Empowering Elementary African American Children to Achieve Academic Success}

Many problems confront educators who seek to overcome roadblocks to academic success of African American students, particularly those in urban areas. Reviewing some of the factors of which educators should be cognizant as they develop intervention strategies to help African American urban students and others achieve success is the subject of this section.

\section{Biases of the U.S. Information Media}

The everyday success experienced by many African American youth is often overlooked by the media in search of negatives to just slander the African American people (Gary, 1994). Despite impoverished surroundings, 
single-parent households, and other material impediments to their achievement, many of these youngsters find a way to succeed in the academic environment (Booker, 1995).

The undue focus on the numbers of young black men in jails and prison or enmeshed in violence, or afflicted by drug addiction, among other problems, has served to overshadow those who overcome the long odds and achieve success in school (Fordham \& Ogbu, 1986).

\section{Eight of the Most Important Factors to Foster Academic Success}

1. Encouraging a positive home environment. A positive home environment where the youngster, like Martin Luther king may be involved in church, community activities and other African American institutions is very conducive to the youngsters' academic success (Comer, 1986).

2. Transforming the peer group. Today, youth peer groups are considered to be detrimental to the educational and moral development of youth. Yet under ideal circumstances peer group members can encourage one another to achieve academically (Fordham \& Ogbu, 1986). Unfortunately, today, such encouragement occurs only in higher socioeconomic social contexts. Educators must try to overcome this situation and use positive youthful interactions such as: various kinds of collective assignments, study groups, study teams, and academic contests or competitions (National Center for Education Statistics, 1991). 
3. Establishing goals early in life. Successful people establish goals and aspirations early in life. Parents and teachers must have a continuous dialogue with youngsters to pinpoint their interest and help them establishing short- and long-term goals. Establishing a long-term goal encourages long-term thinking and diminishes the tendency toward seeking immediate gratification (Hodgkinson, 1990):

4. The need for racial pride and awareness. A well-publicized journal article focusing on a black urban high school concluded that African American students were deterred from learning by the fear of "acting white" (Fordham \& Ogbu, 1986). Despite a number of positive changes within American society within the past 3 decades Black youth remain bombarded by negative, debilitating, anti-Black messages via the media, the educational system, and other sources. Consequently the African American people are losing a great number of its finest youngsters through "EGO DYSTONIC POVERTY" which is a disharmony with a positive view of self (Booker \& Gary, 1995)

These debilitating messages so prone to provoke in the youngsters' minds "ego dystonic poverty" can be counteracted through concrete knowledge of both the history and the contemporary situation of African Americans (Kunjufu, 1983).

It is crucial that both the history and the 
current situation be early framed in terms of the victories and achievements that have been won in a struggle against the seemingly insurmountable obstacles Africans, West Indians, African Americans, and other members of the African forced diaspora in the past 400 years, including the most monstrous beast: racism (Coleman et al., 1966). Yet, this empowering sense of history should transcend a focus solely upon African Americans and should stress the role of Blacks in the ancient world as well as in other countries today. Understanding this rich history will make it clear in the mind of so many bright youngsters that learning and skill development are human qualities not white ones (Woodard, 1995)

studies today indicate that black self-esteem in America is as high as or even higher than that of whites. Yet this should be no source of comfort for the African American people, since many analysts have also asserted that such self-esteem derives from non-academic aspects of personality or activity (Jackson \& Cooper, 1992; Mcclelland et al., 1981; Seeley, 1989; Swap, 1990). Parents and teachers have a special role to play in fostering the academic self-confidence in their children and students.' But they must first believe that they can achieve. It should be made clear to African American students that blacks can achieve academically just as they do athletically. The existence of past and 
present "academic Michael Jordans" should be made clear and stressed to the mind of youngsters in urban areas. At the same time, it must be made clear that Michael Jordan developed his extraordinary athletic talents through constant, consistent hard work as well as through having good teachers and parents to encourage him to excel (Kunjufu, 1983).

\section{Utilizing African American culture to foster}

achievement. Several contemporary educational experts have pinpointed a distinct African American learning style. They say that African American students learn better in an environment full of human interaction and verbal dialogue, rather than in the still, passive, teacher-dominated mode of instruction so prevalent in American mainstream classrooms. While research on this subject remains underdeveloped, it appears that changes in the method of pedagogy would foster higher academic achievement among African Americans (Barone, 1993).

clearly the instructional style used in urban mostly African American schools should be congruent with the cognitive styles of African American students. This instruction should build on the abilities and skills that the children bring with them from the home environment. Thus, the ideal classroom environment for African American youngsters would include lively and varied activity (Jackson \& Cooper, 1992).

6. Fostering a sense of self-control. High 
achievement is always associated with a high degree of self-control. Successful individuals tend to feel more empowered than do those who are less successful. Most successful people have been able either to avoid or cope with personal disaster. There are many potential causes for anger to develop within the contemporary African American community. Successful people learn to direct their rage at being disadvantaged into strategic and rational goal-directed activity. An important attribute of success is the ability to channel rage constructively (Fordham \& Ogbu, 1986).

7. African American students in inner-cities because of their endemic academic disadvantages must receive more individualized attention. Where programs offering mentoring relationships to students do not exist, efforts should be made to establish such programs. All youth can benefit from the assistance, guidance, and support of a qualified mentor (Booker, 1995).

A mentor can answer questions concerning school, career choices, and life in general. In addition, the mentor can provide more individualized attention to the student's problems than can counselors and others who must deal with many students. A mentor can establish the dialogue which is so efficacious to foster short- and long-term goals. A mentor can be the first link in a career-based network of support (Jackson et al., 1988). 8. Fostering and cultivating academic 
motivation. There is a Nigerian proverb, "Not to know is bad, not to wish to know is worse." It is tragic that the natural curiosity of many youngsters is suffocated during the very years that the opportunity to learn and develop skills is the greatest. One basic task of parents and educators is to cultivate or, when beginning from scratch, develop this natural thirst for knowledge (Fordham \& Ogbu, 1986).

The student should be encouraged to begin thinking early about long-range career and personal goals. Youngsters should be exposed to a variety of potential career areas and be encouraged to pursue one in which he or she has a long-term interest. The development of long-range perspectives is important. other priorities can fall into place around this career aspiration. Long-range perspectives involving hope and social mobility have been described by more than one researcher (Taylor et al., 1991) as the best form of birth control.

Perhaps most important of all however, is a sense of spirituality that weaves all these disparate previous elements together. A faith in oneself, and a faith in one's family, friends, and community, in combination with the belief that being successful is nothing but keeping on trying (Comer, 1986).

Knowledge of the frustration and personal crises experienced and overcome by famous Black men and women 
can also serve as psychic support at times. This type of resiliency can be developed partially by encouraging youngsters to study biographies of famous African Americans. In particular vicariously experiencing the successes and failures of figures such as Frederick Douglas, Martin Luther King, Malcolm X, Jackie Robinson, and Harriet Tubman should be particularly inspiring (Heilbrun \& Waters, 1984).

\section{Summary}

Successful individuals understand the importance of developing their cognitive skills. Cognitive competencies are needed to function effectively in American society. These skills include the ability to express oneself maturely and intelligently to solve reasoning problems and to compete. The motivation to achieve a high degree of cognitive development must eventually become internalized.

It is clear that technological change is accelerating even beyond the fast pace of the 1980s. Good cognitive skills will be a key element in the ability to adapt to the changes that will be inevitable in the years to come. African Americans as well as others must accept learning and skill development as a life-long process. All of the above may help, but the waging of a war on ignorance engaging the whole nation and its economical strength is the only viable solution 
to the educational problem of America (Ziesemer, 1984).

\section{Modern Organizational Theory}

Modern theoretical considerations deducted from modern organizational theory are distinct from the classical and neoclassical considerations because they rely on empirical considerations. They approach the study of an organization--such as Benton Harbor elementary schools as a system. Scott (1973) noted that "they treat organization as a system of mutually dependent variables" (p. 108). There are some types of questions that the other two theories do not consider.

These questions include:

1. What are the strategic means used by the system to succeed?

2. What is the nature of their mutual dependency?

3. What are the main purposes in the system that link the parts together and facilitate their adjustment to each other?

4. What are the goals sought by systems of education?

The literature is replete with pathological studies that are based on the fallacious assumption that the African American child is a kind of deviant or sick White child. Indeed, the search of literature reveals that most of the studies of the African American family 
have been undergirded by this assumption. This kind of "blaming the victim" analysis has resulted in a plethora of "deficit" studies. It is somewhat strange and paradoxical that this kind of pejorative approach to the study of the African American family and child was started by E. Franklin Frazier, an African American sociologist who wrote the first major treatise on the African American family in 1939. Much of the succeeding research utilized the Frazierian approach of relying on census data, hospital records, and court records for data that were extensibly spurious.

This study intends to look at the African American child in crisis instead of the crisis of the African American child. The crisis of being "at-risk" is a time of great danger whose outcome decides whether possible bad consequences will follow. In this respect, the African American child and family are in crisis in Benton Harbor. In the area of cut-backs, rollbacks, take backs and no backs, the most oppressed people in the history of this country are certainly in danger (McMillan, 1986). A country that has been built on the precepts of racism and white supremacy has retarded itself by oppressing the very group of people whom it regarded as "beasts of burden" and chattel (Payne, 1984). As Dr. Martin Luther King said so eloquently: "You cannot hold a man back without holding yourself back." In order to keep me down physically, morally, or socially, you 
must bend your back and stoop to my level ever so often. Nakasone, one of the last First Ministers of Japan, a second-world nation vying for hegemony in the world, insulted several minority group leaders a few years ago with his statement regarding America's intellectual lag. He said that this was a result of the drag of Hispanics, African Americans, and American Indians. However, on close analysis, he was correct. America has retarded herself by engaging in so many methods of oppression, which include slavery, peonage, lynchings, and discrimination. As long as one American child or family is in crisis, America as a world leader among the nations is in crisis (Friere, 1980). Earthquakes, volcanoes, floods, nuclear blasts, mass killings, pestilence, famine, endless wars, and disputes are all indications of a world in crisis. However, into this crisis (to be at-risk) the poor innercity African American child is born. There is no way that this African American child can cause a crisis. On the contrary, this innocent child is a victim of 256 years of slavery, 101 years of segregation, and 42 years of the most insidious kind of racism known to man: systematic attempt of elimination of the Black males (Heilbrun \& Waters, 1984).

Therefore, this study, rather than engaging in the kind of academic flagellation ushered in by the Fraziers (1939), Moynihans (1980), and Moyers (1983) 
attempts to extol the strengths of the African American child and family and to recommend that all these Michigan agencies and institutions take a fresh look at this African American child--in dire crisis in Benton Harbor. It is hoped this study will encourage us to proceed on a positive note as we forge out programs to save the African American child and his or her family. one of the greatest feats in all of human history has been the protracted struggle and survival of the African American family and its children in spite of the horrors of the middle passage, the long night of slavery, and the nadir of discrimination (Roumain, 1939).

There is a plethora of research on the African American child that extols his strengths and virtues. Hale (1984), Wilson (1987), and Kunjufu (1983) are among the African American scholars who have taken this approach in studying the African American child. This approach follows the earlier research on the African American child and family by Andrew Billingsley, Robert Hill, and Robert staples. This approach can be summarized in the title of a paper by one of America's foremost African American family researchers, Wade Nobles, who wrote "Africa's Root and America's Fruit." In reviewing the literature on the African American child's education, several natural characteristics are identified in most studies. The characteristics are idiosyncratically African American and are 
borne out in the kind of "duality of socialization" depicted by Dubois in 1903, as a "double consciousness" or "two worrying souls in one dark body." This kind of push-and-pull dynamic has resulted in a Black child whose very psyche is forged from the African principle of "I am because we are and because we are, therefore I am." Some of these characteristics are listed below.

The African American child:

1. is people-oriented

2. is rhythmic

3. has a high-level sensory motor ability

4. prefers oral-aural modalities for learning communication

5. is highly affective

6. expresses himself/herself through considerable body language.

These characteristics of the African American child emanate from an African ethos that stresses the "survival of the tribe" rather than "the survival of the fittest," and "oneness with nature" rather than "control of nature."

Perhaps the most seminal piece of research on children of African descent was conducted by Geber in 1958. In this study, she compared African and European psychomotor development. Her results revealed that the Black child in the preschool period--indeed in infancy--surpasses the European child in terms of 
psychomotor development. These findings have been corroborated by Bayley in 1965 and Knoblock and Pasamanick in 1953 (McMillan, 1986).

In the past few years, several Black scholars, including Pasteur and Tolston, have shown the high correlation between intellectual development and melanin, a substance in the body that produces color pigmentation. Black children who are blessed with high concentrations of this natural substance enter life with a clear advantage over children of yellow, red, and white extractions (McMillan, 1986).

So one may ask, if Black children are endowed by the creator with such gifts and attributes, why are they in crisis of being "at-risk?" This study posits that the crisis is in the environment, and not in the children who may be the brightest set of children ever born in the Western hemisphere. This crisis stems from the conditions of life that affect the Black child from point of conception. The single most important determinant of the quality of life is the infant mortality rate (McMillan, 1986). In most urban communities this rate for Black children has quadrupled the rate for white children. In a graph showing infant mortality rates by race from 1940 to 1980 , the infant mortality rate for Blacks doubled the rate for whites in each decade. closely related to the infant mortality rate is the phenomenon of low birth weight (McMillan, 1986). 
As pointed out by a study conducted by Akbar (1985) in behalf of the Children's Defense Fund, "Black babies are more than twice as likely as white babies to be low weight at birth (less than 5.5 pounds). Low birthweight infants are more than 20 times more likely to die in the first year of life" (p. 74) As Wilson (1987) cogently states,

During the prenatal period, the nine-month preparatory period before the American black child is born, or is conscious, even in a primitive way of his existence in the world, let alone what kind of world he is to be born into, he is much more a victim of that world's adverse effects than is any other ethnic American child. (p. 109)

This Black child suffers from the physical, emotional, political, economic, and psychological consequences of the Black condition in America. He or she not only bears the scars of antebellum slavery, but also the stripes of modern-day slavery whose tendrils extend deep into the hearts of the American inner-city ghetto. Unemployment, joblessness, and miseducation are inextricably linked to high crime rates, high prison rates, increasing suicide rates, high rates of homicides, etc. The percentage of Black children in poverty is a staggering $89 \%$ according to Akbar (1985). Although children as a cohort group are America's poorest, Black children are unquestionably the poorest set of people in America.

The plight of the Black male child is linked to the future of Black people in this country. If there are not Black males to "father the race" the hope of some 
conspirators is that the Black family will indeed vanish. "The struggle continues--in the words of the great black clinical psychologist, Dr. Bobby Wright--we will win without a doubt" (McMillan, 1986).

\section{Necessity of a Good Primary Education}

The necessary transformation of American primary education over the whole nation tends to produce in the inner city a new institution--the magnet school (Carnegie Commission on Primary Education, 1988). Indeed, it has come to be recognized as an "American invention" and a refusal to accept fatalism (Staten, 1990). The U.S. magnet school, as a model, is admired and may eventually be imitated around the world (Phlegar \& Rose, 1988). It has enlarged and expanded the mission of education beyond the failures of the early grades (Johnson, 1987). The viability of the development and administration of a modified, successful inner-city academic program for the elementary schools of Benton Harbor, or any inner-city primary school for that matter, will mean a more employable population, a better informed citizenry, a more active and stimulating community (Lange \& Koos, 1991).

It is time to stop talking nonsense about the failure of African American education (Knight, Waxman, \& Hersholt, 1990). It is time rather to start dealing with the hard, cruel facts of the problem of the schools in 
the ghetto--which is in turn the very core of the race problem in the United States (Alsop, 1990). School desegregation must always remain a central goal; but sad experience has proved that, however aggressively pursued, it is far from being an instant remedy (Orr, 1987). The inescapable truth is that the problem of inefficient education for the children who live in the ghetto must be mainly solved inside the inner-city schools, at least for a long time to come (Davis, 1991). National experts' opinions in the areas of at-risk students' education and the successful inner-city programs will be heavily weighed.

According to the following national experts in the area of at-risk students, the inner-city kids fail because of the circumstances in which our society condemns them to live. The great majority of African American children normally enter the first grade considerably behind white children of the suburbs (Weikel, 1991). They generally fall further and further behind the longer they stay in school (Nedsker \& Tillery, 1987). On average, those who stay through high school are by then $31 / 2$ years below grade level, which means only slightly better than an eighth-grade education (Margolin, 1991). Benton Harbor high school graduates score at the ninth-grade level ("Benton Harbor School System: Failure Rate," 1992). More than 400,000 18-year-old African Americans are annually injected into this country's socio-economic 
bloodstream, but hardly $10 \%$ of these have the true equivalent of a normal high-school education (Bauch, 1982). Public schools annually add to the American workforce approximately 360,000 African Americans who are unequipped to get or hold a decent job. This, because of grossly deficient schooling, will be an added burden to the whole American workforce (Howe \& Edelman, 1985). To this frightening number, 50,000 of 18-year-old "dropouts" of all strata must be added each year (Hanson et al., 1991). The successful magnet school recognizes that children who live in the ghetto have all the potential of any other children. Their apparent handicap comes from their background of deprivation. They seem to inherit a heavy handicap that must be overcome by an intensive and long-range educational cure (Ellington, 1990; Higbee \& Dwinell, 1990; Midkiff et al., 1991; Reiff et al., 1990). This study intends to propose an effective cure for the African American youth of Benton Harbor elementary schools. This comes after diligently and carefully studying the concomitant problems facing most of the "at-risk" African American students in this school system.

\section{Preschool and Early Childhood Education May Be Necessary in Benton Harbor}

All children need a good educational start, and at no time is the need more pronounced than in the early 
years of African American pupils of inner-cities. The promotion of high-quality preschool education was widely hailed by all the national experts in the area of at-risk students and by such researchers as curwood (1983), wilhelm (1980), Friere (1980), Perkins (1984), and Campbell (1985).

Research shows that preschool education is a bargain both for the children themselves and for taxpayers and society generally. A good start in school lessens the need for special education and tutorial programs, and also lessens the chances of having to repeat a grade. In turn, greater school success leads to greater success in adolescence and adulthood through less delinquency, a drop in welfare-use rates, a decline in high-school dropout rates, a drop in teen pregnancy, and a reluctance to participate in crimes (Arnez, 1978; Green \& Washington, 1983).

An excellent example of the benefits of preschool education can be found in ypsilanti, where the nationally acclaimed Perry preschool is located. A scientifically selected and monitored group of African American children was followed from the time the youngsters entered the Perry program until after they reached the age of high-school graduation. Results showed that the preschool students did better in subsequent regular grades than other pupils in the same school, dropped out less frequently, and were in trouble 
with the law less often (Coté, 1986). Several schools of that kind might be the solution for the endemic educational problems for the African American pupils of Benton Harbor.

The necessity of suggesting positive changes in the learning difficulties observed among the at-risk African American students enrolled in the elementary schools of Benton Harbor is imperative. However, the inner-city African American child crisis of the city does not seem likely to be diffused solely by the Benton Harbor area school district's efforts. It is a crisis that cannot be diffused unless all the concomitant causes and potential remedies are tackled together. Their conclusions and recommendations, along with the latest research data, may be streamlined and consolidated to spell out that so many problems affecting the inner-city African American children of Benton Harbor entangle one another in such a way that it is impossible to provide tidy distinctions on all issues.

The inner-city African American children face a crisis before they are even born (Coté, 1986). Many have mothers who are young, poor, and uneducated. Fathers often are absent from the family. The result is that African American infant mortality is on the rise, and those children who do survive often suffer malnutrition, child abuse, or a lack of loving discipline and standards (Cochran et al., 1982). Michigan's inner-city African 
American student achievement at all levels is of crisis proportion (Coté, 1986). Dreams of success evaporate into helplessness or bitterness without education that prepares African American children for worthwhile jobs. There is a wide gap between the well-being of African American and White children and their families (Atkinson, 1983).

Problems in physical and mental health often are trig-gered by poverty, ignorance, crime, drugs, and discrimination. Unemployment is obviously the major contributing factor toward poverty and, less directly, toward crime and poor physical and mental health (Chachere \& Johnston, 1982). The desegregation of schools in the U.S., which was supposed to be apparently a positive step toward African American education, seems to be a handicap in Benton Harbor. How? As says Edelman (1993),

the segregated black schools of the recent past fared much better as far as equipping a minority child with the 3 Rs. It is because the church was a hub of black children's social existence, and caring black adults were buffers against the segregated and hostile outside world that told us we were not important. But our parents said it wasn't so, our teachers said it wasn't so, and our preachers said it wasn't so. The message of my racially segregated childhood was clear: let no man or woman look down on you and look down on no man or woman. (p. 122)

According to Edelman (1993) the actual teacher-student racial imbalance, the early motherhood, and the young parents' immaturity and isolation, and specifically the lack of Black community input, tend to destroy the selfworth of the children in American inner-city's ghetto schools. 
There are a number of demonstration programs across the country, showing that if you manage schools in a way to involve parents, staff, and communities, you can change the culture of the schools and promote development of kids in a way that makes adequate teaching and learning possible. (Comer, 1988, p. 141)

Education does not exist in a vacuum, he said, adding that it must provide economic development and opportunities for both parents and students. "You need it for parents so that you promote the kind of stability that allows them to prepare their children for school" (p. 145) .

In developing and administrating a modified academic program in the elementary schools of Benton Harbor, we are trying to change some basic ingrained attitudes and to help people understand why the problem is different from the past. As said by Dr. James Comer,

It is not just a matter of parents not caring enough, teachers not making enough of an effort, and kids not being motivated. It is more complicated than that. It is a combination of changing the nature of the economy and the existing culture that created the instability of family and community, and also raising the level of development necessary to help more people participate in the economy. (1988, p. 157)

The education of "at-risk" African American students of Benton Harbor is a risk we must necessarily take if not by altruism than even by selfishness. "By 1970, a half-million students--one-seventh of those enrolled in U.S. colleges--came from poverty backgrounds" (Maxwel1, 1988, p. 17) . Today, with added agendas, many of those university-sponsored programs are working to 
stimulate the K-12 pipeline with educational and social support for both students and their families. In the process, educators are gaining an education themselves far from the ivory tower (Margolin, 1988).

\section{In the Shadow of the Ivory Tower}

Principles that guide the Boston University/ Chelsea Partnership are simple: "Children should be ready to learn, teachers should be ready to teach, and there must be something important to teach" ("Chelsea's Renaissance," 1990, p. 6) according to a partnership study presented to the Massachusetts Legislature in 1989.

Decades ago in the small city of Chelsea, those principles were the guiding force for one of the nation's finest school systems. It faithfully served generations of Italian, Jewish, and Irish immigrants and sent them off to the Ivy League.

In recent years however, Chelsea, Boston's neighbor to the northeast and the state's poorest city, has struggled. The official census figure of 33,000 is mainly minority. Nearly three-quarters of the students in chelsea's public school system come consequently from minority groups, including 55\% Hispanic, $12 \%$ Asian, and 6\% African American. More than $50 \%$ of the students entering the district are deficient in the English language. Virtually no one went on to a 4-year college or even took the Scholastic Aptitude Test. Teachers had little respect for 
themselves, much less the students or the school, says Boston University spokesman Chris Donogouh, speaking about Chelsea's Renaissance (1990).

In desperation, Mayor John Brennan implored the Boston University to intervene. Armed with a plan, a 10year contract, and a host of faculty and administrators, Boston University President, John Silber, set out to clean up a decaying school system--and some critics say-- a city. The cornerstone of the partnership is an early childhood education program, even though current preschoolers will not graduate for at least 5 years after the program ends in the year 2000, Donogouh says. Since the start of the partnership when Diana Lam, Chelsea's new superintendent, was hired, more than $\$ 800,000$ in computers were replaced, school curriculum was revised, alternative primary and high-school programs were set up, and an adult-literacy campaign was launched.

\section{A Creative Approach Toward Greater Equity}

David A. Davis, a doctoral student at Ball state University, who heads Ball State's Early Outreach Program for middle- and high-school students, says too many universities still cling to the traditional means of recruiting students--college fairs and high-school visits. Davis says:

When you are talking about early outreach, there are only a small number of universities that have decided to take a creative approach. Universities can no 
longer see themselves as existing solely to educate. Many societal needs dictate that institutions of higher learning get involved in problem-solving and that they foster greater equity. (1989, p. 18)

saying that the mandate to recruit students should come from the top, Davis noted that the directive on Ball State's campus of more than 20,000 students came from President John E. Worthen. Davis also attributes 1992 's record enroliment of 855 minority students to aggressive recruitment and programs such as Early outreach.

A combination of problems confronting inner-city African American students and their families demands a "combination of programs" (cited in Davis, 1989, p. 3), says Ethel Caldwell, who directs the Early Outreach Program at the University of Illinois. Jose Elizondo, one of Caldwell's students, credits his decision to become a physician to the program's career and mentoring component. "I learned many things . . . but what really made an impression on me was a small get-together that the Early Outreach Program coordinated on Medicine as a career" ( $p$. 28). A year later, Elizondo made his decision to study medicine (Cochran, 1982).

\section{Charting success}

Any Early outreach Program may be funded by the federally backed efforts known as the TRIO PROGRAM:

Upward Bound, (2) student support Services, and (3)

Talent Search and Educational opportunity Centers

(Edmonds, 1979). Benton Harbor is not a lost case. The 
71

students can learn and will eventually learn and take off to the Ivy League schools of this great nation. However, for this unbelievable and wonderful dream to come true, teachers, administrators, parents, and particularly the institutions of higher learning of this area must lend a charitable hand toward a creative approach for greater equity for all.

\section{Summary}

The research reported here follows the model of the most extensive and the most comprehensive work on atriskness ever done by Jack Frymier (1989). It first began with a review of the research on factors that contribute to at-riskness. The intention from the outset was to develop an instrument or scale to measure atriskness that would be both valid and practical for educators to use. In attempting to develop an index of at-riskness, two models were considered, the medical model and the psychiatric model (Tables 1,2 , and 3 , pp. 5, 6. and 7).

According to Frymier (1989), the medical model can be illustrated by describing the approach to dealing with coronary heart disease. Typically, a patient is assessed to be at risk of heart attack on the basis of the following factors: family history, cholesterol levels, smoking, hypertension, obesity, and level of exercise. The probability of each factor is assessed, 
but the interactive effects of several factors are also determined.

Psychiatrists deal with the complexities of human behavior by distinguishing between two things: predisposing factors (those that develop over a long period of time, usually more than two years), and shortterm life events, which are usually of short duration (six months or less). Examples of the long-term predisposing factors would include such things as marital discord in a home over a period of years, or long-term unemployment.

Short-term life events such as the loss of a loved one, divorce, or an unplanned pregnancy illustrate the second category. Psychiatrists presume that shortterm life events may affect persons who have predisposing factors and accelerate the deterioration of an individual's.mental health.

In this context, truancy, emotional disturbance, social biases, deterioration of the family unit, poverty, and political and economic powerlessness seem to contribute to at-riskness. Alternative education appears to be a viable means for revitalizing not only some inner-city school systems but also the entire structure of America's public education. 
CHAPTER III

\section{METHODOLOGY}

\section{Introduction}

It would appear that the problem of school truancy, retention, and subsequent academic failure is a major educational crisis that puts students at risk in the Benton Harbor area schools for a variety of reasons, such as teenage pregnancy, substance abuse, addiction, or dropout. This poses a major and critical challenge to the whole educational enterprise in the Benton Harbor area.

This situation is particularly critical among African American students. Statistically, it is estimated by the school authorities that $80 \%$ of African American students enrolled in the primary schools in Benton Harbor fall in the "at-risk" category (Ellington, 1990)

The purpose of this study has been to determine the concomitant educational problems facing the "at-risk" African American students in the Benton Harbor elementary school system and to suggest positive changes through an alternative model. 
Research Questions

Specifically, this study addressed two basic questions:

1. What are the perceived concomitant educational problems facing the African American at-risk elementary students in Benton Harbor elementary schools?

2. Is there a need for change in Benton Harbor school system?

The two basic questions above were set forth with very detailed and precise descriptions in the form of the following four null hypotheses in order to clearly and thoroughly explore the respondents' answers.

\section{Nul1 Hypotheses}

Hypothesis 1

There is no significant difference between the parents', teachers', and administrators' perceived concomitant educational problems due to teachers' burnout, lack of discipline, and low academic achievement in reading, mathematics, and science.

\section{Hypothesis 2}

There is no significant difference between parents and the teachers of Benton Harbor elementary schools with respect to the need for change within the school system. 
Hypothesis 3

There is no significant difference between the parents and administrators of Benton Harbor elementary schools with respect to the need for change within the school system.

\section{Hypothesis 4}

There is no significant difference between the teachers and administrators of Benton Harbor elementary schools with respect to the need for change within the school system.

\section{Research Design}

Descriptive/survey research strategies have been utilized in this study for collecting data on the perceived educational needs and how a modified curriculum based on the recommendations may satisfy those needs for all elementary schools in Benton Harbor.

\section{Instrumentation}

Based on theoretical considerations, certain factors contribute to psychoeducational problems among ethnic minorities such as those largely represented within the Benton Harbor community/sub-culture.

$$
\text { One questionnaire was necessary for the study }
$$

(see appendix A). No appropriate instrument/ questionnaire was found in the literature that effectively addresses those problems (psychoeducational) 
within such a sub-culture as Benton Harbor. Questions in the form of a questionnaire were developed to gather information from parents, teachers, and principals at the elementary school level.

The questions were generated based on theoretical considerations, a review of the relevant literature, and on the researcher's dialogue with informed educators of "at-risk" students. Six such schools across the United states were contacted for the sole purpose of gathering relevant and reliable information for the questionnaire.

\section{Steps in the Questionnaire Development}

Four steps were taken to develop the instrument:

1. Items were generated based on theoretical considerations.

2. Experts in the field of "at-risk" students were consulted regarding nature of the questions.

3. The instrument was critiqued by experts in the field of study ("at-risk" students), researched, and statistics searched for reliability through test and retest.

4. The instrument was modified under the supervision of my committee and the advisement of a research adviser appointed by the committee. 


\section{Description of the Questionnaire}

The questionnaire consisted of 51 questions of a closed nature. This descriptive/research instrument has been divided in three main parts. The first part contains 32 questions asked the of 13 primary school principals of Benton Harbor. Those questions attempted to earn the assent of these school administrators, for a probable change in the curriculum. The second component posed 15 questions to the 170 primary school classroom teachers of Benton Harbor. These questions sought to elicit how intense the crisis is in terms of discipline breakdown and teacher burnout in those primary schools. They also intended to engage the teaching staff's cooperation for the probable implementation of a new curriculum. Teachers were asked to gather information from parents, due to the nature of the population, given their economic, social, and educational status in Benton Harbor. The third component addressed only four questions to 520 parents. These questions sought opinions of the parents/guardians on the introduction of new remedial programs in the city of Benton Harbor primary schools. Changes in the curricula of science, mathematics, and reading skills are suggested. Such changes should better meet the educational needs of "atrisk" African American students at the elementary level. Through the results of this elaborate questionnaire addressed to a total of 703 concerned and informed 
adults, it can also be assessed in what respects the recommendations of this study can, if evaluated and implemented, remedially satisfy the educational needs of these "at-risk" African American students enrolled in Benton Harbor elementary schools.

Thus the descriptive survey research method has met most of the objectives of this study. The purpose has been to compare the opinions held by various groups of 703 informed and potential respondents. This is an attempt to clearly assess the educational needs of the "at-risk" elementary school African American youth of the Benton Harbor area schools, and how to satisfactorily cater to them.

\section{Procedure}

The researcher sent a letter to the superintendent of the Benton Harbor Area School District, stating the desire to undertake the study and requesting permission from the Benton Harbor Education Board of Trustees to administer the questionnaire (see Appendix B). Upon receiving permission, I administered the questionnaire to all elementary school administrators and faculty/staff in closed settings. Parents/guardians received their questionnaire through the mail or via their children. Six chosen academic academies were contacted. They are: Chelsea, Massachusetts; Ypsilanti, Michigan; Bethel, Washington; Montgomery, Alabama; 
Morganton, North Carolina; and Urban School System, East Tennessee. This was done either by letter or telephone call, or both, to assess the level of their success in dealing with "at-risk" ethnic minorities. The library of Benton Harbor Academic Academy was used to study academic academy catalogs. Other catalogs were requested from alternative schools to reflect control-type whether public, private for profit, private for non-profit, or church-related.

\section{Population and Sample}

The population has been defined as the most relevant representatives for "at-risk" elementary school African American students of Benton Harbor. The Benton Harbor Area School District serves Benton Harbor and immediately adjacent communities in a 56-square-mile service area containing a population of 44,000 . The school authorities enroll 7,200. (K-Adult Education) with a. racial/ethnic population of $80 \%$ African Americans, $19 \%$ White, and $1 \%$ other. Two-thirds of Benton Harbor families are single-parent families. The school system reports an annual dropout rate of $12 \%$, and a $10 \%$ teenage pregnancy rate, reflecting 158 live births to teenage mothers (Ellington, 1990). It also reported 4,091 secondary suspensions and 957 elementary suspensions during the 1989-1990 school year. School authorities have identified 4,700 of $6,900 \mathrm{~K}-12$ students as high-risk 
youth. They reported 2,755 enrolled in the secondary schools. They estimated that $80 \%$ of the 4,145 students enrolled in the elementary schools are somewhat "atrisk." This implies that 3,316 elementary students may be considered "at-risk" in the school district of Benton Harbor. From this "at-risk" population according to school authorities, $80 \%$ are African Americans (2,653 students). It is assumed that there is at least one parent/guardian per each student.

The total sample size included 703 informed respondents. Each member of the population sample is given an equal chance of being randomly selected.

The 13 main administrators were personally contacted by the researcher for submitting the questionnaire to the different primary schools of the Benton Harbor area schools. The letter informed them of the intention to complete the study and solicited their assistance in encouraging teachers to respond. Their response was friendly, warm, and supportive. (See Appendix B.)

\section{Summary}

The descriptive survey method of research has been used to explore the manifest educational needs of elementary school African American youth of the Benton Harbor Area School District constituency. One questionnaire was used in this study. The population 
sample of respondents for the "at-risk" African American students consisted of 703 subjects. They are African American parents (548), teachers (142), and administrators (13). Each member of this restricted population sample was asked to fill out a part of the questionnaire related to its group.

The data were analyzed through the SPSS/PC program under the direct guidance of Dr. Jerry Thayer. The statistical analysis was examined and not approved by him after six years of constant and interminable corrections. 
CHAPTER IV

PRESENTATION AND ANALYSIS OF DATA

\section{Introduction}

A brief background of the problem that this study has attempted to solve seems necessary at this point. The Benton Harbor school system has had many problems over the years, especially in dealing with youth who drop out of junior and senior high schools. It appears that a large number of students ( $80 \%$ ) who have not yet dropped out fall in the category of "at-risk" youth.

Statistics abound on the devastating consequences of the "at-risk" youth (Glazer, 1989). For example, many of these "at-risk" students become dropouts, juvenile law offenders, crime prone, pregnant, and victims of crime within the city of Benton Harbor and the surrounding areas.

The purpose of this study was to determine the concomitant educational problems facing the "at-risk" African American students in the Benton Harbor elementary school system and to suggest positive changes through an alternative model.

Out of the 170 teachers who received the questionnaire, 115 chose to respond about their 
preference for changes that should be made in the Benton Harbor elementary schools' curriculum.

The following questions were asked of 142

teachers in the Benton Harbor area primary schools from kindergarten to fifth grade in order to assess teacher satisfaction.

\section{Questionnaire section I}

Teacher Satisfaction

\section{Question 1}

Question 1 asked: What grade level do you teach? (See Table 5.)

TABLE 5

GRADE LEVEL TAUGHT

\begin{tabular}{|l|c|c|c|}
\hline \multicolumn{1}{|c|}{ Grade Level Taught } & $\begin{array}{c}\text { Total No. } \\
\text { of Teachers } \\
\text { Per Grade }\end{array}$ & $\begin{array}{c}\text { Total No. of } \\
\text { Teachers Per } \\
\text { Grade Who } \\
\text { Responded }\end{array}$ & $\begin{array}{c}\text { Percentage } \\
\text { of Response }\end{array}$ \\
\hline Kindergarten & 29 & 18 & 15.7 \\
1st Grade & 33 & 18 & 15.7 \\
2nd Grade & 23 & 19 & 16.5 \\
3rd Grade & 22 & 19 & 16.5 \\
4th Grade & 20 & 19 & 16.5 \\
5th Grade & 23 & 22 & 19.1 \\
6th Grade & 20 & 0 & 0 \\
\hline \multicolumn{1}{|c|}{ TOTAL } & 170 & 115 & 100 \\
\hline
\end{tabular}


Data collected indicated that not all the teachers responded. Twenty-nine teachers teach at the kindergarten level in the Benton Harbor area schools; only 18 of them responded. At the first-grade level, there are 33 teachers, and 18 of them returned the questionnaire. There are $23,22,20$, and 23 teachers teaching in the second grade, third grade, fourth grade, and fifth grade, respectively. As it can be seen from Table 5, there are fewer teachers who responded to the questionnaire than the total number of teachers in each category.

Question 2

Question 2 asked: How many years of teaching experience do you have? (See Table 6.)

TABLE 6

YEARS OF TEACHING EXPERIENCE

\begin{tabular}{|l|c|c|c|}
\hline $\begin{array}{c}\text { Years of Teaching } \\
\text { Experience }\end{array}$ & $\begin{array}{c}\text { Total No. of } \\
\text { Teachers }\end{array}$ & $\begin{array}{c}\text { Total No. of } \\
\text { Teachers who } \\
\text { Responded }\end{array}$ & $\begin{array}{c}\text { Percentage } \\
\text { of Response }\end{array}$ \\
\hline 1 to 5 years & 142 & 31 & 21.8 \\
6 to 10 years & 142 & 72 & 50.7 \\
11 to 20 years & 142 & 35 & 24.6 \\
Above 21 years & 142 & 4 & 2.8 \\
\hline
\end{tabular}


out of the 142 teachers who answered this question, 103 of them have taught only between 1-10 years. From this response, it is clear that $72 \%$ of the teachers are relatively new in this school system. This bulk of young and relatively new teachers indicates a constant, high teacher turnover in this system.

The last two categories, $11-20$ years and above 20 years, represent $28 \%$ (39 teachers) of the 142 teachers who responded. As can be seen from Table 6, 31 teachers (21\%) responded to having taught only between 1-5 years. Seventy-two teachers $(52 \%)$ responded to having taught between 6-10 years. Thirty-five teachers (25\%) have taught between 11-20 years, and only four teachers (3\%) have taught more than 20 years.

\section{Question 3}

Question 3 asked: How many years have you taught in this school? (See Table 7.)

This question has been subdivided in five categories, varying from 0 years to more than 8 years. Six percent ( 8 teachers) taught only 0-2 years in the same school. The second category, 32 teachers (23\%), taught in the same school for 3-4 years. The third category of $5-6$ years in the same school represents $23 \%$ (33 teachers). The fourth category has $22 \%$ (31 teachers), whereas the fifth category of more than 8 years in the same school shows 26\% (38 teachers). 
TABLE 7

YEARS TAUGHT IN THIS SCHOOL

\begin{tabular}{|l|c|c|c|}
\hline $\begin{array}{c}\text { Years Taught in } \\
\text { This School }\end{array}$ & $\begin{array}{c}\text { Total No. of } \\
\text { Respondents }\end{array}$ & $\begin{array}{c}\text { Total No. of } \\
\text { Teachers Who } \\
\text { Responded Per } \\
\text { Category }\end{array}$ & $\begin{array}{c}\text { Percentage } \\
\text { of Response }\end{array}$ \\
\hline 0 to 2 years & 142 & 8 & 6 \\
3 to 4 years & 142 & 32 & 23 \\
5 to 6 years & 142 & 33 & 23 \\
7 to 8 years & 142 & 31 & 22 \\
More than 8 years & 142 & 38 & 26 \\
\hline
\end{tabular}

\section{Question 4}

Question 4 asked: What is the level of satisfaction you enjoyed from this work? (See Table 8.)

TABLE 8

LEVEL OF SATISFACTION

\begin{tabular}{|l|c|c|c|}
\hline Level of Satisfaction & $\begin{array}{c}\text { Total No. of } \\
\text { Teachers Who } \\
\text { Responded }\end{array}$ & $\begin{array}{c}\text { Total No. of } \\
\text { Teachers Per } \\
\text { Category }\end{array}$ & $\begin{array}{c}\text { Percentage } \\
\text { of Response }\end{array}$ \\
\hline Not Satisfied & 142 & 5 & 4 \\
Little Satisfaction & 142 & 16 & 11 \\
So-so & 142 & 70 & 49 \\
Satisfied & 142 & 49 & 35 \\
Very Satisfied & 142 & 2 & 1 \\
\hline
\end{tabular}

From the response to this question, it appears that the level of dissatisfaction of $64 \%$ of the teachers is evident. Subdivided in five categories, the responses to the first three categories show 91 teachers (64\%) who 
responded out of 142 are not satisfied. (See definition of terms, p. 12.)

The first category has five teachers (4\%) who are definitely not satisfied.

Sixteen out of 142 teachers (11\%) chose the second category, little satisfaction.

The third category of undecided, so-so, was chosen by 70 teachers ( $49 \%$ ) out of 142 who responded.

Forty-nine (35\%) out of 142 teachers who responded say that they are satisfied with their work. The fifth category was chosen by only two teachers (1\%) who respond that they are very satisfied.

Considering the answers to the above question, one may say that $15 \%$ of the teachers are mainly not satisfied, $49 \%$ are undecided, and only $36 \%$ expressed some satisfaction with their work.

\section{Question 5}

Question 5 asked: In your line of work, which one of the following five factors is foremost to you as job satisfaction? (See Table 9.)

From Table 9 it is evident that a first group of 28 teachers answered and ranked the five propositions from first to fifth. Only $25 \%$ ( 7 teachers) in that group ranked High Salary first in job satisfaction.

Twenty-four teachers out of 58 (41\%) ranked Students' High Achievement first, and $40 \%$ ranked it second. 
TABLE 9

FACTOR FOREMOST IN JOB SATISFACTION

\begin{tabular}{|c|c|c|c|c|c|c|c|}
\hline & Ranked & $1 \mathbf{s t}$ & $2 n d$ & $3 r d$ & 4 th & $5 t h$ & Total \\
\hline (1) & High Salary & 7 & 4 & 7 & 2 & 8 & 28 \\
\hline (2) & $\begin{array}{l}\text { Students' High } \\
\text { Achievement }\end{array}$ & 24 & 23 & 6 & 5 & 0 & 58 \\
\hline (3) & Work security & 48 & 4 & 4 & 28 & 0 & 84 \\
\hline (4) & $\begin{array}{l}\text { Excellent } \\
\text { Working } \\
\text { Conditions }\end{array}$ & 28 & 4 & 3 & 8 & 5 & 48 \\
\hline (5) & $\begin{array}{l}\text { Self- } \\
\text { Actualization }\end{array}$ & 3 & 2 & 7 & 2 & 16 & 30 \\
\hline & Total & 110 & 37 & 27 & 45 & 29 & \\
\hline
\end{tabular}

of the 84 teachers who chose work Security, 48 teachers (57\%) saw it as the foremost factor in job satisfaction.

of the 48 teachers, 58\% (28 teachers) ranked Excellent Working Conditions as the first factor in job satisfaction.

only 30 teachers answered and ranked selfActualization. Ten percent ( 3 teachers) in this group ranked it first, and 53\% (16 teachers) ranked it fifth.

\section{Question 6}

Question 6 asked: How would you rate the discipline problem in your school? (See Table 10.) 
TABLE 10

\section{DISCIPLINE RATED}

\begin{tabular}{|l|c|c|c|}
\hline \multicolumn{1}{|c|}{$\begin{array}{c}\text { Discipline in Your } \\
\text { School }\end{array}$} & $\begin{array}{c}\text { Total No. of } \\
\text { Teachers Who } \\
\text { Responded }\end{array}$ & $\begin{array}{c}\text { Total No. of } \\
\text { Teachers Per } \\
\text { Answer }\end{array}$ & $\begin{array}{c}\text { Percentage } \\
\text { of Response }\end{array}$ \\
\hline Not good & 141 & 13 & 9 \\
Fair & 141 & 44 & 31 \\
Good & 141 & 82 & 58 \\
Very good & 141 & 2 & 2 \\
\hline
\end{tabular}

This question had four possible answers: 1, not good; 2, fair; 3, good; and 4, very good.

"Not good" was chosen by 13 teachers (9\%) out of 141 .

"Fair" was chosen by 44 (31\%) out of the 141 teachers. "Good," expressing that the disciplinary measures are good, was chosen by 82 teachers (58\%) out of the 141. The last answer, that the disciplinary measures are very good, was chosen by only 2 teachers (2\%) out of the 141.

An overwhelming portion of teachers (91\%) who chose to respond to the questionnaire believed that the discipline is either fair, good, or very good in their school.

\section{Question 7}

Question 7 asked: In your opinion, what are the foremost factors responsible for absence of discipline in 
the classroom? Respondents were to check more than one answer. (See Table 11.)

TABLE 11

FACTORS FOR ABSENCE OF DISCIPLINE: YES OR NO

\begin{tabular}{|l|c|c|c|}
\hline $\begin{array}{c}\text { Foremost Factor } \\
\text { Responsible for } \\
\text { Absence of Discipline }\end{array}$ & $\begin{array}{c}\text { Total No. of } \\
\text { Teachers Who } \\
\text { Responded }\end{array}$ & $\begin{array}{c}\text { Total No. of } \\
\text { Teachers }\end{array}$ & $\begin{array}{c}\text { Percentage } \\
\text { of Response }\end{array}$ \\
\hline $\begin{array}{l}\text { (1) } \begin{array}{l}\text { Students' low } \\
\text { self-esteem }\end{array} \\
\text { (2) Family values } \\
\text { predominate }\end{array}$ & 57 & 142 & 40 \\
(4) Lack of cooper- & 40 & 142 & 23 \\
ation between \\
parents and \\
teachers
\end{tabular}

The question indicates six possible factors responsible for absence of discipline in the classroom.

The first factor is students' low self-esteem. This was chosen by $40 \%$ of the teachers (57 out of the 142 who responded) .

The second factor is family values. This was chosen by 40 of the 142 teachers (28\%) who responded. The third factor, lack of cooperation between parents and teachers, was chosen by 33 out of the 142 teachers $(23 \%)$ who responded.

The fourth factor is the lack of interest in 
learning. Fifty-five teachers (39\%) out of the 142 saw lack of interest in learning as the foremost factor responsible for the absence of discipline in the classroom.

The fifth factor is poor methodology used. Thirty of the teachers $(21 \%)$ out of the 142 who responded admitted that poor methodology might be the foremost factor responsible for the absence of discipline in the classroom. The sixth factor is the students' emotional problems. This factor was chosen by 33 teachers $(23 \%)$ of the 142 who responded.

The true causes of absence of discipline seem to be a combination of these six factors. It appears, however, that the first and the fourth factors considered, "students' low self-esteem" and "lack of interest in learning," might be primarily responsible for the absence of discipline in the classroom. Teachers seem to believe that the students' low self-esteem (40\%) and lack of interest in learning (39\%) appear to be the foremost causes of poor behavior in the classroom. It may be that these elements are symptoms of other deep problems of which the causes are still unexplored.

Question 8

Question 8 asked: How would you rate your students' academic achievement as compared to the national average? (See Table 12.) 
TABLE 12

STUDENT ACHIEVEMENT

\begin{tabular}{|l|c|c|c|}
\hline $\begin{array}{c}\text { Student Achievement } \\
\text { Compared to National } \\
\text { Average }\end{array}$ & $\begin{array}{c}\text { Total No. of } \\
\text { Teachers Who } \\
\text { Responded }\end{array}$ & $\begin{array}{c}\text { Total No. of } \\
\text { Teachers Per } \\
\text { Rating }\end{array}$ & $\begin{array}{c}\text { Percentage } \\
\text { of Response }\end{array}$ \\
\hline Very low & 140 & 19 & 14 \\
Low & 140 & 44 & 31 \\
Average & 140 & 45 & 32 \\
Good & 140 & 29 & 21 \\
Very good & 140 & 3 & 2 \\
\hline
\end{tabular}

Five possible responses were available to teachers: very low; low; average; good; and very good. "Very low" was chosen by 19 teachers (14\%) out of 140 teachers. Surprisingly, another 44 teachers (31\%) out of the 140 who responded chose their students' academic achievement to be low as compared to the national average. Thus 63 teachers (45\%) admitted that their students' academic achievement is either very low or low as compared to the national average.

Forty-five teachers (32\%) see their students' academic achievement as average.

Twenty-nine teachers (21\%), out of the 140 who responded, chose "good" with regard to their students' academic achievement.

The fifth rating, "very good," was chosen by only three teachers out of the 140 teachers who responded. Those three teachers represent only $2 \%$ of the total number of teachers who responded. According to $45 \%$ of 
the teachers' own estimation, their students' achievement compared to the national average is low or even very low.

\section{ouestion 9}

Question 9 asked: If you were offered a teaching position in another school district where the discipline and the students' academic achievement were rated as "very good" but with a salary 5-15\% lower, would you accept? (See Table 13.)

TABLE 13

MOVING TO ANOTHER TEACHING POSITION

\begin{tabular}{|c|c|c|c|}
\hline $\begin{array}{l}\text { Decision to Move to } \\
\text { Another Teaching } \\
\text { Position Based on } \\
\text { Discipline, Student } \\
\text { Achievement, and 5-158 } \\
\text { Salary Cut }\end{array}$ & $\begin{array}{l}\text { Total No. of } \\
\text { Teachers who } \\
\text { Responded }\end{array}$ & $\begin{array}{c}\text { Total No. of } \\
\text { Teachers Per } \\
\text { Answer }\end{array}$ & $\begin{array}{l}\text { Percentage } \\
\text { of Response }\end{array}$ \\
\hline Yes & 142 & 13 & 9 \\
\hline No & 142 & 62 & 44 \\
\hline Maybe & 142 & 19 & 13 \\
\hline Cannot say & 142 & 48 & 34 \\
\hline
\end{tabular}

This question offered four possible answers: yes, no, maybe, and cannot say.

Thirteen teachers (9\%) out of the 142 who responded chose the first answer, "yes."

"No" was chosen by 62 teachers, representing $44 \%$ of the total number of 142 who responded.

Nineteen teachers (13\%) chose the response "maybe." Forty-eight teachers (34\%) just said "cannot say." 
For all practical purposes, yes, maybe, and cannot say are considered to be willingness to move if all the other factors are satisfactory.

\section{Questionnaire section II \\ Parents' and' Students' Attitude \\ Towards School Work According \\ to Teachers' Assessment}

The following nine questions, related to students and their parents, were asked of 170 classroom teachers. one hundred forty-two answered and gave their assessment about these two groups' attitude toward school work.

Questions 1 and 2 of section II of the survey were cancelled because they have been answered already in Section I of the survey. So number 3 becomes number 1 and so forth.

Question 1

Question 1 asked: According to your own perception what is your students' ethnic background? (See Table 14.)

In this question, 142 teachers who returned the questionnaire were asked to state the number of students he/she has from each of the ethnic groups according to his/her own perception. The four main ethnic groups considered for this study were White, Black, Hispanic, and others. 
TABLE 14

ETHNIC BACKGROUND ACCORDING TO TEACHER'S PERCEPTION

\begin{tabular}{|l|c|c|}
\hline \multicolumn{1}{|c|}{$\begin{array}{c}\text { Student Ethnic } \\
\text { Composition }\end{array}$} & $\begin{array}{c}\text { Percentage of } \\
\text { Teacher's } \\
\text { Perception of } \\
\text { Ethnic } \\
\text { Background }\end{array}$ \\
\hline White & 499 & 25 \\
Black & 1,314 & 66 \\
Ethnic Group & 7 \\
Other & 147 & 1 \\
\hline Total number of students & 29 & 100 \\
(all ethnic groups) & 1,989 & \\
\hline
\end{tabular}

out of the total number, 1,989 students in all ethnic groups, 499 (25\%) are identified as White. The teachers consider 1,314 students (66\%) as Black. They also identify 147 students (75) out of the 1,989 as Hispanic. They also see 29 students (1\%) as others. Extrapolating those results, we may match the information received from the school authorities in Benton Harbor.

School authorities in Benton Harbor have identified 4,700 of the $6,900 \mathrm{~K}-12$ students as high-risk youth. They reported 2,755 enrolled in the secondary schools. It is estimated that $80 \%$ of the 4,145 students, which is 3,316 enrolled in the elementary schools, are somewhat "at-risk." From this "at-risk" population, 2,653 students are African Americans, which represents $80 \%$ of the 3,316 total at-risk students. Out of 170 
elementary school teachers, 142 responded to this questionnaire. Total population of the teaching staff answering this section indicated that $66 \%$ of their students are African Americans, as the answer to question 1, Section II, suggests.

Question 2

Question 2 asked: As far as you can assess, what type of family setting do your students represent? (See Table 15.)

TABLE 15

TYPE OF FAMILY

\begin{tabular}{|c|c|c|c|}
\hline & Family setting & $\begin{array}{l}\text { Total No. of } \\
\text { Students Per } \\
\text { Type of Family }\end{array}$ & $\begin{array}{c}\text { Percentage } \\
\text { of } \\
\text { Responses }\end{array}$ \\
\hline (a) & $\begin{array}{l}\text { Students living with } \\
\text { mother and father }\end{array}$ & 485 & 23 \\
\hline (b) & $\begin{array}{l}\text { Students living with } \\
\text { grandparents }\end{array}$ & 356 & 17 \\
\hline (c) & $\begin{array}{l}\text { Students living with } \\
\text { mother and stepfather }\end{array}$ & 452 & 22 \\
\hline (d) & $\begin{array}{l}\text { Students living with } \\
\text { mother or father only }\end{array}$ & 558 & 27 \\
\hline (e) & $\begin{array}{l}\text { Students living in foster } \\
\text { homes }\end{array}$ & 222 & 11 \\
\hline \multicolumn{2}{|c|}{$\begin{array}{l}\text { Total number of students } \\
\text { (all types of family) }\end{array}$} & 2,073 & 100 \\
\hline
\end{tabular}

The request presents five types of families. In the first type of family, students are living with mother and father. In the second type, students are living with grandparents. The third type of family is characterized 
by students living with mother and stepfather. In the fourth type, students are living with mother or father only. In the fifth type, students are living in foster homes.

Out of the total number of 2,073 students living in all types of families, 485 students (23\%) live in the first type, which is generally considered to be the ideal type of family: father, mother, and children living together.

The second type of family accounts for 356 (17\%) out of 2,073 students.

In the third type of family, the students live with mother and stepfather. Four hundred fifty-two students out of the total number of 2,073 (22\%) fall in this category.

The fourth type of family, living with mother or father only, has 558 students $(27 \%)$.

The fifth type of family, living in foster homes, has 222 students, representing $11 \%$ of the total population.

Question 3

Question 3 asked: What grade level have the parents of your students completed? (See Table 16.) Five hundred seventy-three (63\%) stated that mothers have not completed the high-school program (part a) . 
In addition, the number of mothers who had completed high school was sought (part b). Five hundred seventy-four mothers (63\%) had completed their highschool program, according to the teachers' responses.

TABLE 16

MOTHERS' EDUCATION

\begin{tabular}{|c|c|c|c|}
\hline & $\begin{array}{l}\text { Formal and on-going Education } \\
\text { Completed by Mothers }\end{array}$ & $\begin{array}{l}\text { Total No. of } \\
\text { Mothers Per } \\
\text { Category }\end{array}$ & $\begin{array}{l}\text { Percentage } \\
\text { of } \\
\text { Responses }\end{array}$ \\
\hline (a) & $\begin{array}{l}\text { Mother not graduated from high } \\
\text { school }\end{array}$ & 573 & 63 \\
\hline (b) & $\begin{array}{l}\text { Mother with high-school } \\
\text { education }\end{array}$ & 574 & 63 \\
\hline (c) & Mother with college education & 263 & 29 \\
\hline \multicolumn{2}{|c|}{$\begin{array}{l}\text { Total number of mothers } \\
\text { (all categories) }\end{array}$} & 911 & \\
\hline
\end{tabular}

In response to how many mothers had some college education (part c) it was found that 263 mothers (29\%) had some college education.

It was found that 255 parents $(26 \%)$ had not graduated from high school (Table 17, part d). (See Table 17.)

Regarding how many parents (both father and mother) had completed a high-school education (part e), it was found that 466 parents (48\%) had completed a highschool education.

In response to section $f$, it was found that only 80 parents, representing $8 \%$, had some college education. 
Next, the homes that had basic educational materials was looked at.

In response to the number of families were getting newspapers regularly (Table.18, part g), it was found that 329 families out of 972 (34\%) answered

TABLE 17

PARENTS' EDUCATION

\begin{tabular}{|c|c|c|c|}
\hline & $\begin{array}{c}\text { Formal Education Completed } \\
\text { by Parents }\end{array}$ & $\begin{array}{l}\text { Total No. of } \\
\text { Parents Per } \\
\text { Category }\end{array}$ & $\begin{array}{c}\text { Percentage } \\
\text { of } \\
\text { Responses }\end{array}$ \\
\hline (d) & $\begin{array}{l}\text { Neither parent graduated from } \\
\text { high school }\end{array}$ & 255 & 26 \\
\hline (e) & $\begin{array}{l}\text { Both parents with high-school } \\
\text { education }\end{array}$ & 466 & 48 \\
\hline (f) & $\begin{array}{l}\text { Both parents with college } \\
\text { education }\end{array}$ & 80 & 8 \\
\hline \multicolumn{2}{|c|}{$\begin{array}{l}\text { Total number of families } \\
\text { all categories) }\end{array}$} & 801 & \\
\hline
\end{tabular}

TABLE 18

EDUCATIONAL MATERIALS

\begin{tabular}{|l|c|c|}
\hline $\begin{array}{c}\text { Families with Basic Educational } \\
\text { Materials }\end{array}$ & $\begin{array}{c}\text { Total No. of } \\
\text { Families Per } \\
\text { Category }\end{array}$ & $\begin{array}{c}\text { Percentage } \\
\text { of } \\
\text { Responses }\end{array}$ \\
\hline $\begin{array}{l}\text { (g) Families getting newspaper } \\
\text { regularly }\end{array}$ & 329 & 34 \\
(h) Families with a set of \\
encyclopedias at home \\
(i) Families with more than 25 books \\
$\begin{array}{l}\text { at home } \\
\text { (j) Families getting any magazine } \\
\text { regularly }\end{array}$ & 216 & 47 \\
\hline $\begin{array}{l}\text { Total number of families } \\
\text { (all categories) }\end{array}$ & 317 & 33 \\
\hline
\end{tabular}


positively. In addition, 216 families (22\%) had a set of encyclopedias at home (part $h$ ).

Four hundred fifty-six families said they have more than 25 books at home (section i). Even though this number represents a bare essential, it revealed that $47 \%$ of the families who responded affirmed having more than this bare essential of 25 books at home. This number has been arbitrarily proposed. Three hundred seventeen families ( $33 \%$ ) indicated receiving at least one magazine regularly (Table 18, section $j$ ).

\section{Question 4}

Question 4 asked: How much TV do your students usually watch each day? (See Table 19.)

Lifestyle and duration of $\mathrm{TV}$ daily watching by the students are presented in Table 19. A total of 1,286 students responded concerning their daily TV habits. Five answers were available for the student to choose from. Each answer represents a different time period varying from none to 5-6 hours.

The first time period, "none," was chosen by 55 ( $4 \%$ ) out of a total of 1,286 students. It could be that they had no TV available to them.

The second time period was 1 hour or less. This was chosen by 149 students representing $12 \%$ of the total number who reported their daily TV habits.

The third time period of 2 hours was chosen by 
TABLE 19

DAILY TV WATCHING

\begin{tabular}{|l|c|c|}
\hline \multicolumn{1}{|c|}{$\begin{array}{c}\text { Student Daily TV Watching } \\
\text { at Home }\end{array}$} & $\begin{array}{c}\text { Total No. of } \\
\text { Students Per } \\
\text { Time Period }\end{array}$ & $\begin{array}{c}\text { Percentage } \\
\text { of } \\
\text { Responses }\end{array}$ \\
\hline None & 55 & 4 \\
(a) 1 hour or less & 149 & 12 \\
(b) 2 hours & 213 & 16 \\
(c) 3-4 hours & 345 & 27 \\
(d) 5-6 hours & 524 & 41 \\
\hline Total number of students & & \\
(al1 categories) & 1,286 & \\
\hline
\end{tabular}

213 students. This represents $16 \%$ of the total number. The fourth period of 3-4 hours was chosen by 345 students (27\%). The fifth period of 5-6 hours was chosen by 524 $(41 \%)$ of the students.

\section{Question 5}

Question 5 asked: Do your students benefit from any adult TV supervision at home?

students' TV viewing habits with or without adult supervision (Section II) are presented in Table 20.

The total number of students responding to this question was 1,061. Their answers have been tallied in two main categories. The first category deals with students with adult supervision at home when watching TV (532 students, or 50\%). The second category represents the students with no adult supervision (529 students, or $50 \%)$ 
TABLE 20

TV SUPERVISION

\begin{tabular}{|l|c|c|}
\hline \multicolumn{1}{|c|}{ TV Supervision } & $\begin{array}{c}\text { Total No. of } \\
\text { Students Per } \\
\text { Category }\end{array}$ & $\begin{array}{c}\text { Percentage } \\
\text { of } \\
\text { Responses }\end{array}$ \\
\hline $\begin{array}{l}\text { Students with an adult when } \\
\text { watching TV } \\
\begin{array}{l}\text { Students with no adult and } \\
\text { choose what they want }\end{array}\end{array}$ & 532 & 50 \\
\hline $\begin{array}{l}\text { Total number of students } \\
\text { (all categories) }\end{array}$ & 529 & 50 \\
\hline
\end{tabular}

\section{Question 6}

Question 6 asked: Do your students benefit from any bedtime supervision? (See Table 21.)

Students and adult bedtime supervision are presented in Table 21 (Section II).

One hundred forty-two teachers were asked the following question about 1,593 students: Do your students benefit from any bedtime adult supervision?

The question provided two possible answers: the first category accounts for the students whose parents set a time for them to go to bed; the second category stands for students who go to bed when they please.

In response to the first category, 800 students (50\%) answered that their parents set a time for them to go to bed.

In response to the second category, 793 students (50\%) go to bed as they please. 
TABLE 21

BEDTIME SUPERVISION

\begin{tabular}{|l|c|c|}
\hline Adult Bedtime supervision & $\begin{array}{c}\text { Total No. of } \\
\text { Students Per } \\
\text { Category }\end{array}$ & $\begin{array}{c}\text { Percentage } \\
\text { of } \\
\text { Responses }\end{array}$ \\
\hline $\begin{array}{l}\text { Students whose parents set a } \\
\text { time to go to bed } \\
\text { Students who go to bed as } \\
\text { they please }\end{array}$ & 800 & 50 \\
\hline $\begin{array}{l}\text { Total number of students } \\
\text { (all categories) }\end{array}$ & 793 & 50 \\
\hline
\end{tabular}

Question 7

Question 7 asked: Do your students read with or to their parents on a regular basis? (See Table 22.)

This question was answered by 1,446 students to their teachers. This question has been subdivided in four main categories. The first category groups students who read with or to their parents on a regular basis almost every day. The second category deals with those who read with or to their parents once or twice a week. The third category is for those students who read with or to their parents once or twice a month. The fourth category concerns those students who never or hardly ever read with or to their parents on a regular basis.

out of a total of 1,446 students represented, 380 (26\%) chose the first category. Three hundred sixtynine students $(25 \%)$ chose the second category. These two categories put together, 749 students (51\%) are considered to be regularly coached by their parents. 
TABLE 22

READING WITH PARENTS

\begin{tabular}{|l|c|c|}
\hline \multicolumn{1}{|c|}{ Reading supervision } & $\begin{array}{c}\text { Total No. of } \\
\text { Students Per } \\
\text { Category }\end{array}$ & $\begin{array}{c}\text { Percentage } \\
\text { of } \\
\text { Responses }\end{array}$ \\
\hline Almost every day & 380 & 26 \\
Once or twice a week & 369 & 25 \\
Once or twice a month & 269 & 19 \\
Never or hardly ever & 428 & 30 \\
\hline Total number of students & & 100 \\
(all categories) & 1,446 & \\
\hline
\end{tabular}

The third category was chosen by 269 students

(19\%). The fourth category was chosen by 428 students, or 30\%. Putting these last two categories together, $49 \%$ of the total number of students who answered do not bene-fit from parental supervision in reading on a regular basis.

\section{Question 8}

Question 8 asked: Do your students discuss lessons they have studied in school with someone at home on a regular basis? (See Table 23.)

Students' academic interaction with someone at home is presented in Table 23.

Question 8 was responded to by 1,496 students. The question provided four possible answers: (1) almost every day; (2) once or twice a week; (3) once or twice a month; and (4) never or hardly ever. Almost the same pattern of responses to question 7 emerges here even though the numbers have slightly changed such as 531 
TABLE 23

DISCUSSING LESSONS WITH SOMEONE AT HOME

\begin{tabular}{|l|c|c|}
\hline $\begin{array}{c}\text { Have Discussion about } \\
\text { School Matters }\end{array}$ & $\begin{array}{c}\text { Total No. of } \\
\text { Students Per } \\
\text { Category }\end{array}$ & $\begin{array}{c}\text { Percentage } \\
\text { of } \\
\text { Responses }\end{array}$ \\
\hline Almost every day & 531 & 36 \\
Once or twice a week & 356 & 24 \\
Once or twice a month & 290 & 19 \\
Never or hardly ever & 319 & 21 \\
\hline Total number of students & & 100 \\
(all categories) & 1,496 & \\
\hline
\end{tabular}

students $(36 \%)$ in the first category, $356(24 \%)$ in the second category, and 290 (19\%) and 319 (21\%) respectively in the third and fourth categories. The percentages are almost the same.

Question 9

Question 9 asked: What is the stability of your students in terms of years of schooling at the same school? (See Table 24.)

Another factor that may be able to explain several academic weaknesses manifested in the Benton Harbor primary school students is the stability of students in terms of years of schooling at the same school. Question 9 presented three possible answers. The first category deals with students who have been in the same school since kindergarten. Out of the total number of 1,449 students who responded, 654 (45\%) of them say they have been in the same school since kindergarten. 
TABLE 24

STUDENT STABILITY

\begin{tabular}{|l|c|c|}
\hline Stability in Terms of Years & $\begin{array}{c}\text { Total No. of } \\
\text { Students Per } \\
\text { Category }\end{array}$ & $\begin{array}{c}\text { Percentage } \\
\text { of } \\
\text { Responses }\end{array}$ \\
\hline $\begin{array}{l}\text { Students who have been in the } \\
\text { same school since } \\
\text { kindergarten } \\
\text { Students who have been in } \\
\text { or more schools from K-4 } \\
\text { Students who have been in } \\
\text { or more schools from K-6 }\end{array}$ & 654 & 32 \\
\hline $\begin{array}{l}\text { Total number of students } \\
\text { (all categories) }\end{array}$ & 327 & 23 \\
\hline
\end{tabular}

For the second category, 468 students (32\%) say they have been in three or more schools for their $\mathrm{K}-4$ program.

For the third category, 327 students (23\%) say they have been in three or more schools for their $\mathrm{K}-6$ program. The mobility of the students may indicate the parents' mobility or dissatisfaction with one school or another.

\section{Questionnaire Section III}

Attitude of Parents Towards Their Children's Education

Section III of the questionnaire addresses mainly the parents of the primary-school students in Benton Harbor. Questionnaires were sent to 520 parents. out of this number, 372 parents responded. This represents $72 \%$ 
This section of the questionnaire is made up of four questions. There are four possible answers for the first question, five each for the second and third questions, and four for the fourth one.

\section{Question 1}

Question 1 asked: As African American parents, do you see education as vital in the struggle for freedom and full equality for your children in America? (See Table 25.)

This question provided four answers. Each answer helps to represent the parents in two main categories. Answers $a$ and $d$ indicate that those parents are not really concerned about an education for their children. Fortunately only $7.0 \%$ of the total population of parents questioned responded that education is not important and $4.0 \%$ deemed it is not necessary for success in life. Out of the 372 parents who responded, an overwhelming $89 \%$ highly value education for their children. Of these 372 parents, 161 chose answer $b$, indicating that they see the importance of education increasing day after day (43\%). Another 171 parents chose answer c (46\%), indicating that education in their view is actually the most important asset for their children.

It is amazing to realize that even though the great majority of the parents do not take any proactive 
TABLE 25

EDUCATION FOR FREEDOM AND EQUALITY

\begin{tabular}{|l|c|c|}
\hline \multicolumn{1}{|c|}{ Importance of Education } & $\begin{array}{c}\text { Total No. of } \\
\text { Parents Per } \\
\text { Category }\end{array}$ & $\begin{array}{c}\text { Percentage } \\
\text { of } \\
\text { Responses }\end{array}$ \\
\hline $\begin{array}{l}\text { a. Not really important } \\
\text { b. Its importance increases } \\
\text { day after day } \\
\begin{array}{l}\text { ct is actually the most } \\
\text { important asset }\end{array} \\
\begin{array}{l}\text { d. It not necessary for } \\
\text { success in life }\end{array}\end{array} \quad 24$ & 73 \\
\hline $\begin{array}{l}\text { Total number of parents } \\
\text { (all categories) }\end{array}$ & 171 & 46 \\
\hline
\end{tabular}

steps to facilitate the education of their children, they still value education for them.

\section{Question 2}

Question 2 asked: As African American parents, do you see education as a vehicle by which your children can control and shape their destiny, build stable communities, provide for their families, and fully realize the fruits of democracy in America? (See Table 26.)

A tally of the answers to this question is again particularly revealing. Three hundred twenty parents $(87 \%)$ out of the total number of 369 who responded favored a good education for their children. This group admits that they are fully convinced that education may serve as a vehicle to a bright future for their children. 
As African American parents, they realize that education can help their children control and shape their destiny, build stable communities, provide for their own families, and fully realize the fruits of democracy.

TABLE 26

\section{EDUCATION AS A VEHICLE}

\begin{tabular}{|c|c|c|}
\hline $\begin{array}{l}\text { Education Necessary for } \\
\text { Success in Democratic society }\end{array}$ & $\begin{array}{l}\text { Total No. of } \\
\text { Parents Per } \\
\text { Category }\end{array}$ & $\begin{array}{l}\text { Percentage } \\
\text { of } \\
\text { Regponseg }\end{array}$ \\
\hline a. Yes, I am fully convinced & 320 & 87 \\
\hline $\begin{array}{l}\text { b. Yes, but I think it is } \\
\text { better to have money } \\
\text { than education }\end{array}$ & 23 & 6 \\
\hline $\begin{array}{l}\text { c. No, education is not } \\
\text { for our people }\end{array}$ & 16 & 4 \\
\hline $\begin{array}{l}\text { d. No, my children rather } \\
\text { need a good job }\end{array}$ & 8 & 2 \\
\hline $\begin{array}{l}\text { e. No, my children do not } \\
\text { need more education } \\
\text { than I }\end{array}$ & 2 & 1 \\
\hline $\begin{array}{l}\text { Total number of parents } \\
\text { (all categories) }\end{array}$ & 369 & \\
\hline
\end{tabular}

The question has been asked in such a way that those who did not answer to $a$ or $b$, admitted that they do not favor education for their children. Answer $b$ was selected by 23 parents $(6 \%)$ out of 369 who responded. Combining those parents who selected answers $a$ and $b$, the total becomes 343 parents $(93 \%)$. This means that $93 \%$ of the parents see education as enriching and desirable for their children.

Regarding answers $c, d$, and $e$, they represent 
only $7 \%$ of the parents who responded "no" to the question. Those 26 parents out of 369 appear to be inconsequential to the purpose of this study. Again, the overwhelming majority of parents favor a good education for their children although they do not seem to know what to do to procure it.

\section{Question 3}

Question 3 asked: As African American parents, do you favor good reading skills and excellent mathematics ability for your children? (See Table 27.)

This question surely rekindles the memory of uneducated parents of their personal struggle with these two subjects. Even though $88 \%$ of the total number of parents who responded favored reading and mathematics for their children, a stiff reticence is observed. Most parents, 326 out of 370 , openly request these subjects for their children in answers $a$ and $c$.

Forty-four of the total number of parents (370) perhaps remember how these two subjects are either unimportant or torturous to the mind. In fact, $12 \%$ of them do not favor these subjects for their children. Tallying the answers recorded in $b, d$, and $e$ gives $a$ total of 44 parents out of the total number of 370 who responded. These parents are not at all in favor of those two subjects for their children. 
TABLE 27

READING SKILLS AND MATHEMATICAL ABILITY

\begin{tabular}{|c|c|c|}
\hline $\begin{array}{l}\text { Reading and Mathematics } \\
\text { skills }\end{array}$ & $\begin{array}{l}\text { Total No. of } \\
\text { Parents Per } \\
\text { Category }\end{array}$ & $\begin{array}{c}\text { Percentage } \\
\text { of } \\
\text { Responses }\end{array}$ \\
\hline $\begin{array}{l}\text { a. Yes, I do because they } \\
\text { are basics }\end{array}$ & 197 & 53 \\
\hline $\begin{array}{l}\text { b. No, I do not because } \\
\text { they are not important } \\
\text { to me }\end{array}$ & 32 & 8 \\
\hline $\begin{array}{l}\text { C. Yes, I strongly } \\
\text { recommend these two } \\
\text { subjects for our young } \\
\text { people }\end{array}$ & 129 & 35 \\
\hline $\begin{array}{l}\text { d. No, if they have money } \\
\text { and a good job those } \\
\text { things are secondary }\end{array}$ & 10 & 3 \\
\hline $\begin{array}{l}\text { e. No, mathematics is too } \\
\text { difficult }\end{array}$ & 2 & 1 \\
\hline $\begin{array}{l}\text { Total number of parents } \\
\text { (all categories). }\end{array}$ & 370 & \\
\hline
\end{tabular}

Question 4

Question 4 asked: Do you think that quality, affordable full-time infant and preschool care and education are important? (See Table 28.)

Fortunately, the parents manifested great wisdom by choosing answers $a, b$, and $c$. All of these three answers place strong emphasis on the value of quality, affordable full-time infant and pre-school care and education. Out of the total number of parents who responded, $96 \%$ of them favored either $a, b$, or $c$ for their very young children.

They seem to recognize, as all educated parents do, that the child's well-being and education can be 
TABLE 28

QUALITY CARE AND EDUCATION FOR INFANTS

\begin{tabular}{|c|c|c|}
\hline Preschool Care and Education & $\begin{array}{l}\text { Total No. of } \\
\text { Parents Per } \\
\text { Category }\end{array}$ & $\begin{array}{l}\text { Percentage } \\
\text { of } \\
\text { Responses }\end{array}$ \\
\hline $\begin{array}{l}\text { a. Yes, I do because our } \\
\text { children need to get off } \\
\text { to a good educational } \\
\text { start }\end{array}$ & 269 & 73 \\
\hline $\begin{array}{l}\text { b. Yes, solid grounding in } \\
\text { the three "Rs" is } \\
\text { necessary }\end{array}$ & 37 & 10 \\
\hline $\begin{array}{l}\text { c. Yes, mastery in the three } \\
\text { "Rs" strengthens self- } \\
\text { esteem }\end{array}$ & 44 & 12 \\
\hline $\begin{array}{l}\text { d. No, because they do not } \\
\text { have any bearing on later } \\
\text { life }\end{array}$ & 18 & 5 \\
\hline $\begin{array}{l}\text { Total number of parents } \\
\text { (all categories) }\end{array}$ & 369 & 100 \\
\hline
\end{tabular}

assured at a very early age. Out of 369 parents who answered, 269, representing 73\%, favored pre-school care and education for infants.

Answer $b$ was chosen by 37 parents out of the total number of $369(10 \%)$ who responded. Some of these parents who responded have even considered this early beginning as a precursor of confidence and self-esteem. out of the 369 parents who responded, 44 of them (12\%) chose answer $\mathrm{c}$ and view early education as very important to the future life of the child.

only $5 \%, 18$ out of the total number of 369 parents, who responded chose answer d. They indicated 
that infant and pre-school care and education do not have anything to do with how well the children will fare in later years.

\section{Questionnaire Section IV}

Administrators' Perception on Programs Needed for At-Risk students

Section IV of the questionnaire addresses the administrators of the primary schools in Benton Harbor. This group has 13 administrators. From this group, 11 administrators returned the questionnaire. This means that $92 \%$ of the administrators expressed their opinions. The 11 administrators were very supportive and instrumental in encouraging their teaching staff to respond to the questionnaire as attested by the correspondence (see appendix B).

This section of the study deals with those in power in Benton Harbor. These are the ones responsible for any changes made in the Benton Harbor school system. This section contains 28 questions, subdivided in five main areas.

Area 1 covers child intervention. It is composed of three items. Area 2, called parent intervention, has three items. Area 3, termed management, deals with seven items. Area 4, covering programs necessary for real change, is composed of five items. Area 5 with 10 items puts emphasis for change in the extracurricular activities for most of the African American youngsters 
deprived of home facilities conducive to learning.

Each question or item had five possible answers. The answers were either $\mathrm{SA}=$ strongly agree, $\mathrm{A}=$ agree, $D=$ disagree, $S D=$ strongly disagree, or $N O=$ no opinion. Each administrator was requested to choose only one answer per question.

\section{Child Intervention}

As educational administrators in the inner-city setting, do you think it is necessary to implement the following programs in Benton Harbor to facilitate learning for at-risk students?

Question 1

Question 1 asked: Do you favor child-care programs so that teenage and other "at-risk" mothers may attend school? (See Table 29.)

out of the 11 administrators who responded, 3 chose SA = strongly agree. Thus, $27 \%$ of the administrators of primary schools in Benton Harbor strongly agree with child intervention for change. This particular child intervention deals with child-care programs so that teenage and other "at-risk" mothers may attend school. Out of the 11 administrators who responded, $7(63.7 \%)$ chose $A=$ agree. one may safely say that $91 \%$ of the administrators in the Benton Harbor primary schools see child-care programs as a necessary commodity. It will enable 
TABLE 29

EDUCATIONAL ADMINISTRATORS' RESPONSES TO PART I, QUESTIONS 1-3

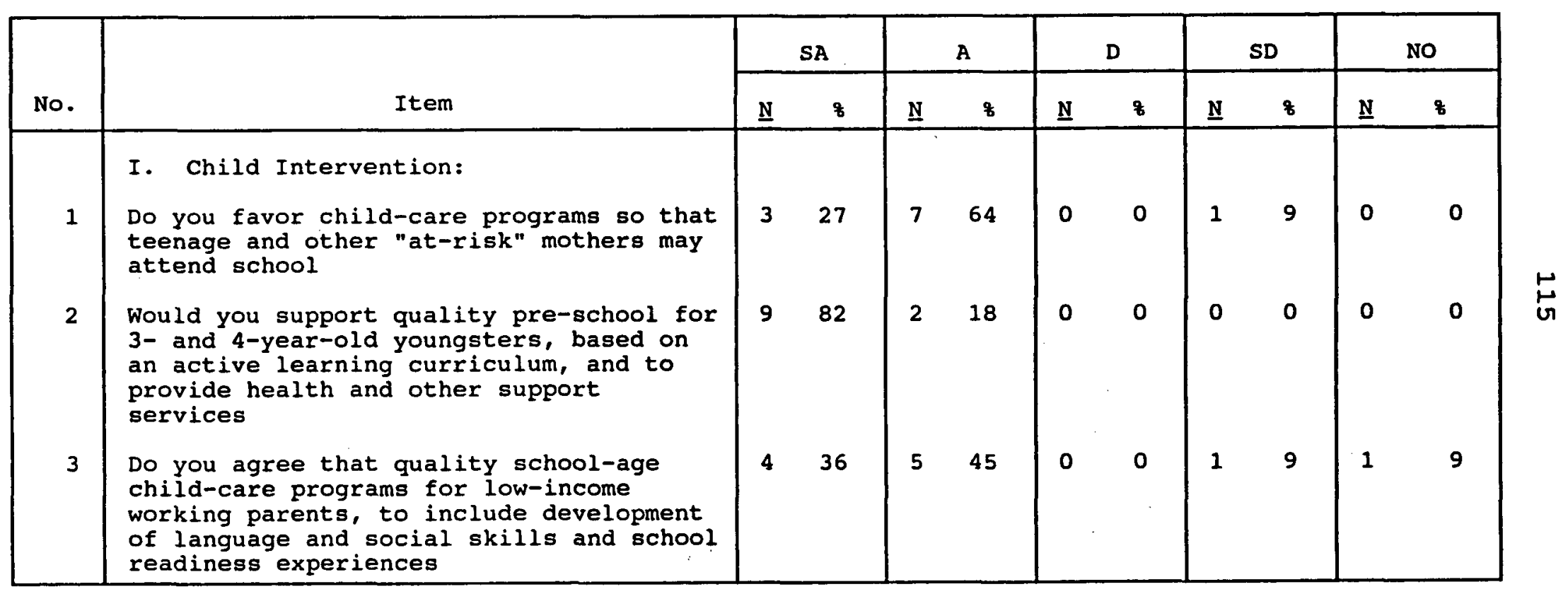

Note. $\quad S A=$ Strongly agree; $A=$ Agree; $D=D$ isagree; $S D=$ Strongly disagree; No = No opinion 
teenage and other "at-risk" mothers to attend school, which is a positive facilitator for change (Burns, 1981; Vasiloff, 1983)

\section{Question 2}

Question 2 asked: Would you support quality preschool for 3- and 4-year-old youngsters, based on an active learning curriculum, to provide health and other support services?

The 13 administrators were asked this question. This proposition is an attempt to enhance the learning ability of most of the African American primary school students in Benton Harbor. According to known research, the implementation of quality preschool for 3- and 4year-old youngsters in underprivileged populations of parents, based on an active learning curriculum providing health and other support services, tremendously enhances the learning ability of those children (Jones, 1982; Morgan, 1980) .

Out of 11 administrators who responded, 9 chose $\mathrm{SA}=$ strongly agree, and 2 out of 11 preferred $\mathrm{A}=$ agree. Thus, $100 \%$ of the administrators who responded are in agreement with that proposition; $82 \%$ chose $\mathrm{SA}=$ strongly agree, and $18 \%$ chose $\mathrm{A}=$ agree.

\section{Question 3}

Question 3 asked: Do you agree that quality school-age child-care programs for low-income working 
parents, to include development of language and social skills and school readiness experiences, should be part of the Benton Harbor school curriculum?

Four out of 11 respondents chose $S A=$ strongly agree, and 5 chose $\mathrm{A}=$ agree. From those answers one may safely conclude that $81 \%$ of the primary-school administrators in Benton Harbor would like to see change involving pre-school-age child-care programs in an effort to booster the learning skills of the deprived great majority of African American youngsters. However $9 \%$ strongly disagreed or gave no opinion with this route for change.

\section{Parent Intervention}

Parent intervention deals with questions 4 to 6 .

\section{Question 4}

Question 4 asked: Do you think that program alternatives and work incentive partnerships with business and industry should be explored to assist teenage and "at-risk" parents to complete high school? (See Table 30.)

out of the 13 administrators, the 11 who responded answered as follows: 4 chose $\mathrm{SA}=$ strongly agree, 5 chose $\mathrm{A}=$ agree, 1 chose $\mathrm{D}=$ disagree, and 1 chose NO $=$ no opinion. This means that $36 \%$ of the administrators strongly want to see implemented some program alternatives and work incentives to assist teenage and "at-risk" parents to complete high school. 
TABLE 30

EDUCATIONAL ADMINISTRATORS' RESPONSES TO PART II, QUESTIONS 4-6

\begin{tabular}{|c|c|c|c|c|c|c|c|c|c|c|c|}
\hline \multirow[b]{2}{*}{ No. } & \multirow[b]{2}{*}{ Item } & \multicolumn{2}{|c|}{ SA } & \multicolumn{2}{|c|}{ A } & \multicolumn{2}{|r|}{ D } & \multicolumn{2}{|c|}{ SD } & \multicolumn{2}{|c|}{ No } \\
\hline & & $\underline{\mathbf{N}}$ & 8 & $\underline{\mathbf{N}}$ & 8 & $\underline{\mathrm{N}}$ & 8 & $\underline{\mathbf{N}}$ & 8 & $\underline{\underline{N}}$ & 8 \\
\hline 4 & $\begin{array}{l}\text { II. Parent Intervention: } \\
\text { Do you think program alternatives and } \\
\text { work incentives (partnerships with } \\
\text { business and industry must be explored) } \\
\text { to assist teenage and "at-risk" parents } \\
\text { to complete high school? }\end{array}$ & 4 & 36 & 5 & 46 & 1 & 9 & 0 & 0 & 1 & 9 \\
\hline 5 & $\begin{array}{l}\text { Do you think it is necessary to } \\
\text { implement some programs to focus on } \\
\text { parenting skills for teenage and "at- } \\
\text { risk" parents to include health care, } \\
\text { nutrition, and intellectual stimulation } \\
\text { for young children? }\end{array}$ & 7 & 64 & 2 & 18 & 1 & 9 & 1 & 9 & 0 & 0 \\
\hline 6 & $\begin{array}{l}\text { Do you think it is necessary to } \\
\text { implement in Benton Harbor pre- and } \\
\text { post-natal health care for pregnant } \\
\text { teens and high-risk mothers? }\end{array}$ & 4 & 36 & 4 & 36 & 2 & 18 & 1 & 9 & 0 & 0 \\
\hline
\end{tabular}

Note. $S A=$ Strongly agree; $A=$ Agree; $D=$ Disagree; $S D=$ Strongly disagree; No $=$ No opinion. 
Out of these 11 administrators, $46 \%$ chose $A=$ agree with that same proposition, while $9 \%$ of them chose either to disagree or to express no opinion. Eighty-two percent of the administrators consulted see the possibility of change for most of the African American youngsters in Benton Harbor primary schools in the alternative of completing high school by the large group of teenage and young-adult dropouts in this city. These administrators realize that the dropouts, juvenile law offenders, the crime prone, the pregnant teenagers, and the victims of crime who are or become parents may be indirectly a negative influence on social skills, academic learning, and behavior of their children who are in the primary schools in Benton Harbor. This has already been found to be true (Nedsker \& Tillery, 1987).

\section{Question 5}

Question 5 asked: Do you think it is necessary to implement some programs to focus on parenting skills for teenage and "at-risk" parents should include health care, nutrition, and intellectual stimulation for young children?

out of the 13 administrators, 11 responded. Seven (64\%) administrators chose $\mathrm{SA}=$ strongly agree. only 2 administrators out of 11 chose $\mathrm{A}=$ agree; and only 1 administrator chose $S D=$ strongly disagree and $\mathrm{D}=$ disagree. 
Question 6

Question 6 asked: Do you think it is necessary to implement in Benton Harbor prenatal and postnatal health care for pregnant teens and high-risk mothers?

of the 11 administrators who responded, 4 (36.5\%) chose SA = strongly agree. Four other administrators $(36.5 \%)$ chose $A=$ agree. Two chose $D=$ disagree, and 1 chose SD = strongly disagree. This means that $73 \%$ of them are in agreement with the proposition while $27 \%$ oppose it.

\section{Management}

The management area is composed of seven questions, 7-13. (See Table 31.)

\section{Question 7}

Question 7 asked: Do you think it is necessary to implement school-based management, participatory decision making, and local accountability?

of the 11 administrators who responded, 5 (45.5\%) chose $S A=$ strongly agree. Whereas $45 \%$ of the administrators would strongly recommend change toward this goal, $45 \%$ of them chose $A=$ agree. Thus, $90 \%$ of the 11 administrators are in agreement with school-based management, participatory decision making, and local accountability forimprovements toward change. However, at the other end of the spectrum, $9 \%$ of the 11 administrators chose $\mathrm{D}=$ disagree. 
TABLE 31

EDUCATIONAL ADMINISTRATORS' RESPONSES TO PART III, QUESTIONS 7-13

\begin{tabular}{|c|c|c|c|c|c|c|c|c|c|c|c|}
\hline \multirow[b]{2}{*}{ No. } & \multirow[b]{2}{*}{ Item } & \multicolumn{2}{|c|}{ SA } & \multicolumn{2}{|c|}{$\mathbf{A}$} & \multicolumn{2}{|c|}{ D } & \multicolumn{2}{|c|}{ SD } & \multicolumn{2}{|c|}{ NO } \\
\hline & & $\underline{N}$ & $\%$ & $\mathbf{N}$ & $\%$ & $\underline{\mathbf{N}}$ & $\%$ & $\underline{\mathbf{N}}$ & $\%$ & $\underline{N}$ & $\%$ \\
\hline & III. Management: & & & & & & & & & & \\
\hline 7 & $\begin{array}{l}\text { Do you think it is necessary to implement school-based } \\
\text { management, participatory decision making, and local } \\
\text { accountability for improvements? }\end{array}$ & 5 & 45 & 5 & 45 & 1 & 9 & 0 & 0 & 0 & 0 \\
\hline 8 & $\begin{array}{l}\text { Do you think it is necessary to implement staff development } \\
\text { programs for administrators and teachers to enable them to work } \\
\text { with citizens of the } 21 \text { st century? }\end{array}$ & 9 & 82 & 1 & 9 & 1 & 9 & 0 & 0 & 0 & 0 \\
\hline 9 & $\begin{array}{l}\text { Do you think it is necessary to use of existing facilities to create } \\
\text { smaller school enrollments and smaller classes? }\end{array}$ & 7 & 64 & 2 & 18 & 2 & 18 & 0 & 0 & 0 & 0 \\
\hline 10 & $\begin{array}{l}\text { Do you think it is necessary to implement partnerships and shared } \\
\text { decision making with business and industry to accomplish } \\
\text { Program } 4 \text { ? }\end{array}$ & 4 & 36 & 6 & 55 & 1 & 9 & 0 & 0 & 0 & 0 \\
\hline 11 & $\begin{array}{l}\text { Do you think it is necessary to implement partnerships with } \\
\text { physical and mental-health care providers to accomplish Program } \\
2 \text { and } 5 ?\end{array}$ & 5 & 46 & 5 & 46 & 1 & 9 & 0 & $\mathbf{0}$ & 0 & 0 \\
\hline 12 & $\begin{array}{l}\text { What do you think about the use of electronic student record } \\
\text { transfer systems (MESRTS) in metro areas? }\end{array}$ & 5 & 45 & 1 & 9 & 1 & 9 & 4 & 36 & 0 & 0 \\
\hline 13 & $\begin{array}{l}\text { What do you think about year around and flexible scheduling to } \\
\text { accommodate community and maximize facility usage? }\end{array}$ & 1 & 9 & 4 & 36 & 3 & 27 & 2 & 18 & 1 & 9 \\
\hline
\end{tabular}

Note. $\mathrm{SA}=$ Strongly agree; $\mathrm{A}=$ Agree; $\mathrm{D}=$ Disagree; $\mathrm{SD}=$ Strongly disageee; $\mathrm{NO}=$ No opinion. 
Question 8

Question 8 asked: Do you think it is necessary to implement staff development programs for administrators and teachers to enable them to work better with citizens of the 21 st century?

staff development programs for administrators and teachers to enable them to work better with citizens of the 21 st century is a viable goal for change. Out of 11 administrators who responded, $9(82 \%)$ of them chose SA $=$ strongly agree. They would like to see some change in the thinking and acting of administrators and teachers toward a better working relationship with their students who will be the citizens of the 21 st century. One of them (98) chose $A=$ agree, and one (98) disagrees.

\section{Question 9}

Question 9 asked: Do you think it is necessary to use existing school facilities, in order to create small school enrollment and smaller classes?

Out of the 11 administrators who responded to the questionnaire, 7 of them $(64 \%)$ chose SA = strongly agree. Another $18 \%$ of the 11 administrators chose $A=$ agree, and the last $18 \%$ expressed disagreement by choosing $D=$ disagree. One may safely assume that $82 \%$ of the 11 administrators want to see changes in the school building that would accommodate smaller classes. This would facilitate the learning process (Higbee \& Dwinell, 1990). 
Question 10

Question 10 asked: Do you think it is necessary to implement partnerships and shared decision making with business and industry to accomplish the program seen in item 4? (Question 4 concerns the program alternatives and work incentives--partnerships with business and industry must be explored--to assist teenage and "atrisk" parents to complete high school.)

out of the 11 administrators who responded, 4 of them $(36 \%)$ chose $\mathrm{SA}=$ strongly agree. This means they want program alternatives and work incentives to assist teenage and other "at-risk" parents to complete high school. Another 55\% ( 6 administrators) chose $A=$ agree. Ninety-one percent of the administrators think that such a program would benefit the learning process of the Benton Harbor primary-school students. One (9\%) of the 11, however, disagrees.

Question 11

Question 11 asked: Do you think it is necessary to implement in Benton Harbor partnerships with physical and mental health care providers to accomplish programs 2 and 5 ?

Program 2 deals with quality preschool for 3 - and 4-year-old youngsters, based on an active learning curriculum, to provide health and other support services. Program 5 concerns quality school-age child care for 
low-income working parents, including development of language and social skills and school readiness experiences. These two programs cover early child intervention in order to prepare the child for a successful school learning process.

out of the 11 administrators who responded, 5 of them chose $\mathrm{SA}=$ strongly agree, 5 chose $\mathrm{A}=$ agree, and 1 chose $D=$ disagree. While $91 \%$ of the 11 administrators are in agreement with the proposition, $9 \%$ are in disagreement with it.

Question 12

Question 12 asked: What do you think about the use of electronic student record transfer systems (MESRTS) in metro areas? (MESRTS stands for Metropolitan Electronic Student Record Transfer Systems.)

out of the 11 administrators who answered the questionnaire, 5 administrators $(46 \%)$ said that they were in strong agreement with the proposition. One out of the 11 administrators (9\%) expressed his/her agreement by choosing $A=$ agree. One $(9 \%)$ of the 11 administrators chose $D=$ disagree, and 4 of them (36\%) expressed SD = strongly disagree.

\section{Question 13}

Question 13 asked: What do you think about year around and flexible scheduling to accommodate the community and maximize facility usage in Benton Harbor? 
of the 11 administrators who chose to answer this question, 1 of them (9\%) agreed strongly with the proposition. Four of them (36\%) chose $A=\operatorname{agree,} 3$ (27\%) chose $\mathrm{D}=$ disagree, 2 (18\%) chose $\mathrm{SD}=$ strongly disagree, and $1(10 \%)$ chose NO = no opinion. This question elicited a wide range of answers. Forty-five percent of them agree with that proposition, whereas $45 \%$ disagree. Ten percent chose No $=$ no opinion.

\section{Program}

Question 14

Question 14 asked: Do you approve of a fluid curriculum to provide Reading and Mathematics basic skills and survival strategies for citizens of the 21st century of Benton Harbor? (See Table 32.)

Three of the 9 administrators (33\%) who responded to this particular question favored $S A=$ strongly agree. Four of them $(45 \%)$ chose $A=$ agree. One of the 9 (11\%) chose $D=$ disagree and $1(11 \%)$ chose $S D=$ strongly disagree.

\section{Question 15}

\section{Question 15 asked: Do you approve of early}

intervention programs such as affordable full-time infant and pre-school care, prenatal classes, academic instruction, counseling, health and social services, and parenting classes? 
TABLE 32

EDUCATIONAL ADMINISTRATORS' RESPONSES TO PART IV, QUESTIONS 14-18

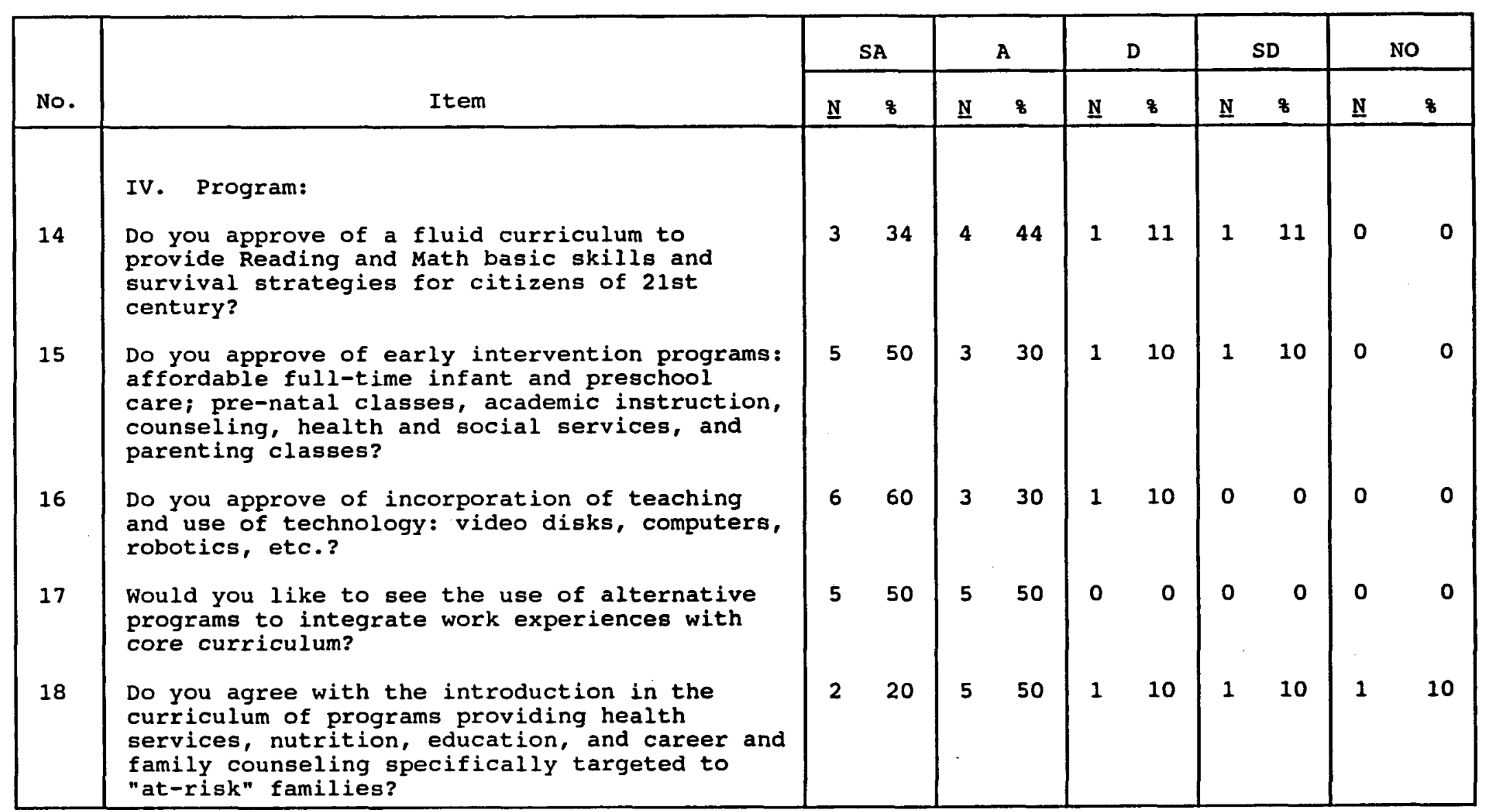

Note. $\quad S A=$ Strongly agree; $A=$ Agree; $D=$ Disagree; $S D=$ Strongly disagree; NO $=$ No opinion. 
Five (50\%) of the 10 administrators who answered chose SA = strongly agree. Three $(30 \%)$ of the 10 chose A = agree. One $(10 \%)$ answered $\mathrm{D}=$ disagree, and 1 (10\%) chose SD = strongly disagree. This means that $80 \%$ of the administrators would favor the introduction of early intervention programs. Twenty percent (2) of them rejected this proposition.

Question 16

Question 16 asked: Do you approve of incorporating teaching and use of technology such as video disks, computers, robotics, etc.?

Six of these 10 administrators (60\%) would strongly favor the introduction of such a program in the curriculum. In the last analysis $90 \%$ of the administrators would see this hands-on education as the most needed in the Benton Harbor elementary schools, since 3 more of them (30\%) agree with the proposition. One administrator (10\%), however, opposes it.

\section{Question 17}

Question 17 asked: Would you like to see the use of alternative programs to integrate work experiences with core curriculum in the Benton Harbor elementary schools?

Five (50\%) out of 10 administrators who chose to respond to this question answered $\mathrm{SA}=$ strongly agree. Another 5 (50\%) chose $A=$ agree. This means that $100 \%$ of 
the administrators accept this proposition.

\section{Question 18}

Question 18 asked: Do you agree with the introduction in the curriculum programs of health services, nutrition, education, career and family counseling specifically targeted to "at-risk" families?

Two (20\%) of the 10 administrators who responded to the questionnaire answered $S A=$ strongly agree, whereas $5(50 \%)$ of the 10 chose $A=$ agree. The three remaining administrators chose $\mathrm{D}=$ disagree $(10 \%), \mathrm{SD}=$ strongly disagree $(10 \%)$, and NO = no opinion (10\%).

\section{Extracurricular}

Question 19

Question 19 asked: Do you think it is necessary to implement programs such as alternative activities, developed with community assistance, to stimulate development of physical and social skills, appreciation of arts and environment in the Benton Harbor elementary schools? (See Table 33.)

Seven $(70 \%)$ of the 10 administrators who responded to this particular question strongly agreed with this proposition. Two (20\%) of the 10 agreed with it, and $1(10 \%)$ chose $D=$ disagree. Thus, $90 \%$ of the 10 administrators would like to see implemented alternative activities that are developed with community assistance. 
TABLE 33

EDUCATIONAL ADMINISTRATORS' RESPONSES TO PART V, QUESTIONS 19-28

\begin{tabular}{|c|c|c|c|c|c|c|c|c|c|c|c|}
\hline \multirow[b]{2}{*}{ No. } & \multirow[b]{2}{*}{ Item } & \multicolumn{2}{|c|}{$S A$} & \multicolumn{2}{|c|}{ A } & \multicolumn{2}{|c|}{ D } & \multicolumn{2}{|c|}{ SD } & \multicolumn{2}{|c|}{ No } \\
\hline & & $\underline{\mathbf{N}}$ & 8 & $\underline{\mathbf{N}}$ & 8 & $\underline{\mathbf{N}}$ & 8 & $\underline{\mathbf{N}}$ & 8 & $\underline{\mathbf{N}}$ & 8 \\
\hline & V. Extracurricular: & & & & & & & & & & \\
\hline 19 & $\begin{array}{l}\text { Do you think it is necessary to implement } \\
\text { programs such as alternative activities, } \\
\text { developed with community assistance, to } \\
\text { stimulate development of physical and social } \\
\text { skills, appreciation of arts and environment? }\end{array}$ & 7 & 70 & 2 & 20 & 1 & 10 & 0 & 0 & 0 & 0 \\
\hline 20 & $\begin{array}{l}\text { Do you favor utilizing cooperative planning } \\
\text { with community to include programs for lifelong } \\
\text { learning, and activities for youth, adults, and } \\
\text { seniors? }\end{array}$ & 5 & 50 & 3 & 30 & 1 & 10 & 1 & 10 & 0 & 0 \\
\hline 21 & $\begin{array}{l}\text { Do you think it is necessary to implement } \\
\text { programs to encourage volunteerism: students, } \\
\text { adults, corporate sector, grandparents, etc.? }\end{array}$ & 5 & 50 & 4 & 40 & 1 & 10 & 0 & 0 & 0 & 0 \\
\hline 22 & $\begin{array}{l}\text { Do you think it is necessary to provide } \\
\text { educational programs that enable all its } \\
\text { primary school students to learn inter-activity } \\
\text { in dyads or small groups, experientially, and } \\
\text { in roles that are both supportive of one } \\
\text { another and that emphasize prior life } \\
\text { experience as germane to mastering new content? }\end{array}$ & 4 & 40 & 6 & 60 & 0 & 0 & 0 & 0 & 0 & 0 \\
\hline 23 & $\begin{array}{l}\text { Do you think that it is necessary to craft } \\
\text { educational experience whereby learners talk } \\
\text { through required processes to have their } \\
\text { questions answered, and to understand that they } \\
\text { are valued, "seen," and appreciated for their } \\
\text { interactive and self-awareness capacities? }\end{array}$ & 4 & 40 & 6 & 60 & 0 & 0 & 0 & 0 & 0 & 0 \\
\hline
\end{tabular}


Table 33--continued.

\begin{tabular}{|c|c|c|c|c|c|c|c|c|c|c|c|}
\hline \multirow[b]{2}{*}{ No. } & \multirow[b]{2}{*}{ Item } & \multicolumn{2}{|c|}{ SA } & \multicolumn{2}{|c|}{ A } & \multicolumn{2}{|c|}{ D } & \multicolumn{2}{|c|}{$S D$} & \multicolumn{2}{|c|}{ No } \\
\hline & & $\underline{\mathbf{N}}$ & 8 & $\underline{\mathbf{N}}$ & 8 & $\underline{\mathbf{N}}$ & 8 & $\underline{\mathbf{N}}$ & 8 & $\underline{\mathbf{N}}$ & z \\
\hline 24 & $\begin{array}{l}\text { Do you think it is necessary to implement a } \\
\text { cooperative environment, one that recognizes and } \\
\text { awards the consciousness of individual differences, } \\
\text { and one that "celebrates mistakes" as a way of } \\
\text { converting confusion and anxiety into a readiness to } \\
\text { benefit from trial-and-error experimentation? }\end{array}$ & 5 & 56 & 3 & 33 & 1 & 11 & 0 & 0 & 0 & 0 \\
\hline 25 & $\begin{array}{l}\text { Do you think it is necessary to provide a friendly } \\
\text { and supportive and non-crowded classroom where the } \\
\text { students can ask for and give help; where are } \\
\text { action, inter-active activities, games, and } \\
\text { opportunities to meet with, speak to, and make } \\
\text { friends of everyone (teachers included)? }\end{array}$ & 6 & 67 & 3 & 33 & 0 & 0 & 0 & 0 & 0 & 0 \\
\hline 26 & $\begin{array}{l}\text { Recognize the appropriateness of Edmond's statement } \\
\text { which states: "We can, whenever and wherever we } \\
\text { choose, successfully teach our children whose } \\
\text { schooling is of interest to us. Whether we do it } \\
\text { must finally depend on how we feel about the fact } \\
\text { that we haven't done it so far;" (Comer, 1986) and } \\
\text { strive to apply it to the benefit of BHAs system }\end{array}$ & 4 & 44 & 5 & 55 & 0 & 0 & 0 & 0 & 0 & 0 \\
\hline 27 & $\begin{array}{l}\text { Do you think it is necessary to provide learning } \\
\text { environments that emphasize drill and practice, the } \\
\text { practical, the applicable, the manipulable, the } \\
\text { immediately correct or most defensible answers, } \\
\text { immediate feedback on performance, and an efficient } \\
\text { workplace? }\end{array}$ & 3 & 33 & 5 & 56 & 1 & 11 & 0 & 0 & 0 & 0 \\
\hline 28 & $\begin{array}{l}\text { Do you think it is necessary to provide an } \\
\text { environment that promotes sequence, reasons, } \\
\text { impersonal problem-solving processes, objectivity, } \\
\text { correct and defensible responses, and intellectual } \\
\text { challenge? }\end{array}$ & 3 & 33 & 6 & 67 & 0 & 0 & 0 & 0 & 0 & 0 \\
\hline
\end{tabular}

Note. $S A=$ Strongly agree; $A=$ Agree; $D=$ Disagree; $S D=$ Strongly disagree; No $=$ No opinion. 
Question 20

Question 20 asked: Do you favor utilizing cooperative planning with the community to include programs for lifelong learning and activities for youth, adults, and seniors in Benton Harbor?

Five $(50 \%)$ of the 10 administrators who responded to this question chose $S A=$ strongly agree, whereas 3 (30\%) of the 10 expressed agreement by choosing $A=$ agree. One $(10 \%)$ chose $D=$ disagree, and $1(10 \%)$ chose $\mathrm{SD}=$ strongly disagree.

\section{Question 21}

Question 21 asked: As educational administrators in the areas of at-risk students, do you think it is necessary to implement programs to encourage volunteerism such as involving students, adults, corporate sector, grandparents, etc. in the Benton Harbor elementary schools?

Five $(50 \%)$ of the 10 administrators chose $\mathrm{SA}=$ strongly agree, whereas $4(40 \%)$ of the 10 chose $\mathrm{A}=$ agree. One $(10 \%)$ out of the 10 chose $D=$ disagree. Thus, $90 \%$ of the administrators are in agreement with this proposition, and $10 \%$ of them are in disagreement with it.

Question 22

Question 22 asked: Do you think it is necessary to provide educational programs which enable all Benton Harbor 
primary school students to learn inter-activity in dyads or small groups, experientially, and in roles that are both supportive of one another and that emphasize prior life experience as germane to mastering new content?

Four ( $40 \%)$ out of the 10 administrators chose $\mathrm{SA}=$ strongly agree. $\operatorname{Six}(60 \%)$ chose $\mathrm{A}=$ agree. Thus, all of the 10 administrators (100\%) favored this proposition.

\section{Question 23}

Question 23 asked: Do you think that it is necessary to craft educational experience whereby learners talk through required processes to have their questions answered, and to understand that they are valued, "seen," and appreciated for their interactive and self-awareness capacities?

Four $(40 \%)$ of the 10 administrators who responded to this question are in strong agreement with this proposition, whereas $6(60 \%)$ chose $A=$ agree, which makes it $100 \%$ of the respondents agree with the proposition.

\section{Question 24}

Question 24 asked: Do you think it is necessary to implement a cooperative environment, one that recognizes and awards the consciousness of individual differences, and one that "celebrates mistakes" as a way of converting confusion and anxiety into a readiness to benefit from trial and error experimentation? 
Five (56\%) of the nine administrators who responded chose $\mathrm{SA}=$ strongly agree, whereas three $(33 \%)$ chose $\mathrm{A}=$ agree. Thus, $89 \%$ of the administrators who responded are in agreement with this proposition, whereas $11 \%$ of them express disagreement.

\section{Question 25}

Question 25 asked: Do you think it is necessary to provide a friendly and supportive and non-crowded classroom where the students can ask for and give help, where are action, interactive activities, games, and opportunities to meet with, speak to, and make friends of everyone (teachers included) in the Benton Harbor elementary schools?

Six $(67 \%)$ of the nine administrators who responded to this question chose $S A=$ strongly agree. The remaining three $(33 \%)$ chose $A=$ agree. Thus, this proposition pleased all of the nine respondents.

Question 26

Question 26 asked: Recognize the apropos of Edmond's statement which states: "We can whenever and wherever we choose, successfully teach our children whose schooling is of interest to us. Whether we do it must finally depend on how we feel about the fact that we haven't done it so far;" and strive to apply it to the benefit of the Benton Harbor area school system. Do you think that reality can be applied to Benton Harbor 
elementary students and their teachers?

Four (45\%) of the nine administrators strongly agree with this idea. Five (55\%) of the nine just agree with it, and thus $100 \%$ of the nine administrators chose to agree with the proposition.

\section{Question 27}

Question 27 asked: Do you think it is necessary to provide in Benton Harbor elementary schools learning environments that emphasize drill and practice, the practical, the applicable, the manipulable, the immediately correct or most defensible answers, immediate feedback on performance, and an efficient work place? Three $(33 \%)$ of the nine administrators who responded chose $\mathrm{SA}=$ strongly agree, whereas five $(55 \%)$ of the nine chose $\mathrm{A}=$ agree. Thus, $89 \%$ of the nine administrators who responded to this question are in agreement with this proposition, and one (11\%) disagrees.

\section{Question 28}

Question 28 asked: Do you think it is necessary to provide Benton Harbor elementary school students an environment that promotes sequence, reasons, impersonal problem-solving processes, objectivity, correct and defensible responses, and intellectual challenge?

Three $(33 \%)$ of the nine administrators who responded to this question chose $\mathrm{SA}=$ strongly agree. Six (67\%) of the nine administrators chose $A=$ agree. 
Thus, $100 \%$ of the nine administrators are in agreement with this proposition.

\section{Desire for Change}

Desire for change (Table 34) as expressed by 142 teachers, 372 parents, and 11 administrators is put in capsule form in the following pages. As taken from the data file, each number is not explained. However, the three following tables, 35, 36, and 37 , are quite simple. They derive from the data of Table 34 . For teachers' questions $5,7,8$, and 9 , any answer expressed by one or two teachers means that they desire change, and is given a value of 2 . If the answer is expressed by 3 , this means that the teachers are undecided and was given a value of 1 . Any answer expressed by 4 or 5 was given a value of 0 . For the four answers, any accumulation of 0 means the teachers expressed desire for no change. Any accumulation of 1.00 or 2.00 , or 3.00 or 4.00 , means they are undecided or do not want change. Any accumulation of 5.00 to 8.00 means they want to see change. The same is true for the parents and the administrators.

For parents' questions $1,2,3$, and 4 , the answers expressed by 1 or 2 mean they desire change, whereas the questions expressed by 4 or 5 mean they desire no change, and 3 means they are undecided.

For the administrators' questions $1,2,3$, and 7 , the answers expressed by 1 or 2 mean they desire change 
TABLE 34

DIFFERENCE IN DESIRE FOR CHANGE BETWEEN TEACHERS, PARENTS, AND ADMINISTRATORS

\begin{tabular}{|c|c|c|c|}
\hline Questions & $\begin{array}{c}\text { Change } \\
2 \mathrm{Pt} .\end{array}$ & $\begin{array}{c}\text { Undecided } \\
1 \text { Pt. }\end{array}$ & $\begin{array}{c}\text { No change } \\
\text { o Pt. }\end{array}$ \\
\hline \multicolumn{4}{|l|}{ Teachers } \\
\hline 5 & 1 or 2 & 3 & 4 or 5 \\
\hline 7 & 1 or 2 & 3 & 4 or 5 \\
\hline 8 & 1 or 2 & 3 & 4 or 5 \\
\hline 9 & 1 or 2 & 3 & 4 \\
\hline \multicolumn{4}{|l|}{ Parents } \\
\hline 3 & 1 or 2 & 3 & 4 or 5 \\
\hline 1 & 1 or 2 & 3 & 4 or 5 \\
\hline 2 & 1 or 2 & 3 & 4 or 5 \\
\hline 4 & 1 or 2 & & 4 or 5 \\
\hline \multicolumn{4}{|c|}{ Administrators } \\
\hline 7 & 1 or 2 & 3 & 4 or 5 \\
\hline 1 & 1 or 2 & 3 & 4 or 5 \\
\hline 2 & 1 or 2 & 3 & 4 or 5 \\
\hline 3 & 1 or 2 & 3 & 4 or 5 \\
\hline
\end{tabular}

TABLE 35

TEACHERS DESIRING CHANGE

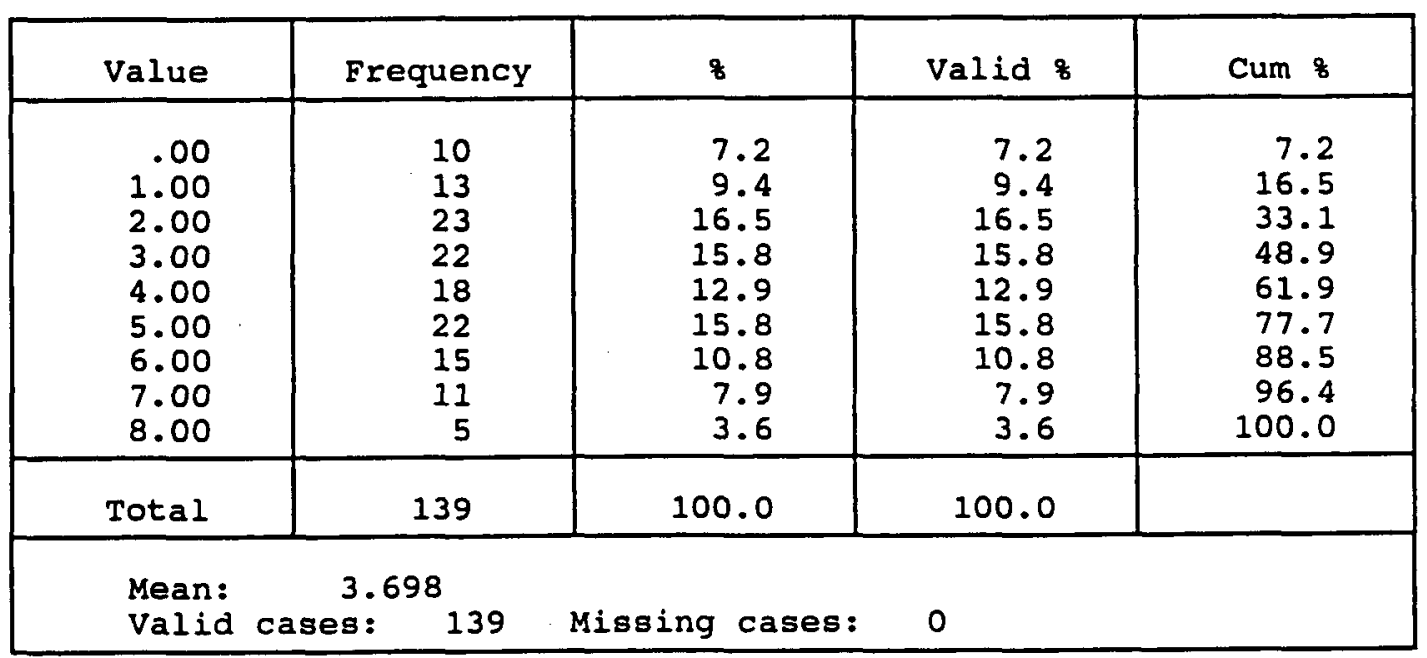


TABLE 36

PARENTS DESIRING CHANGE

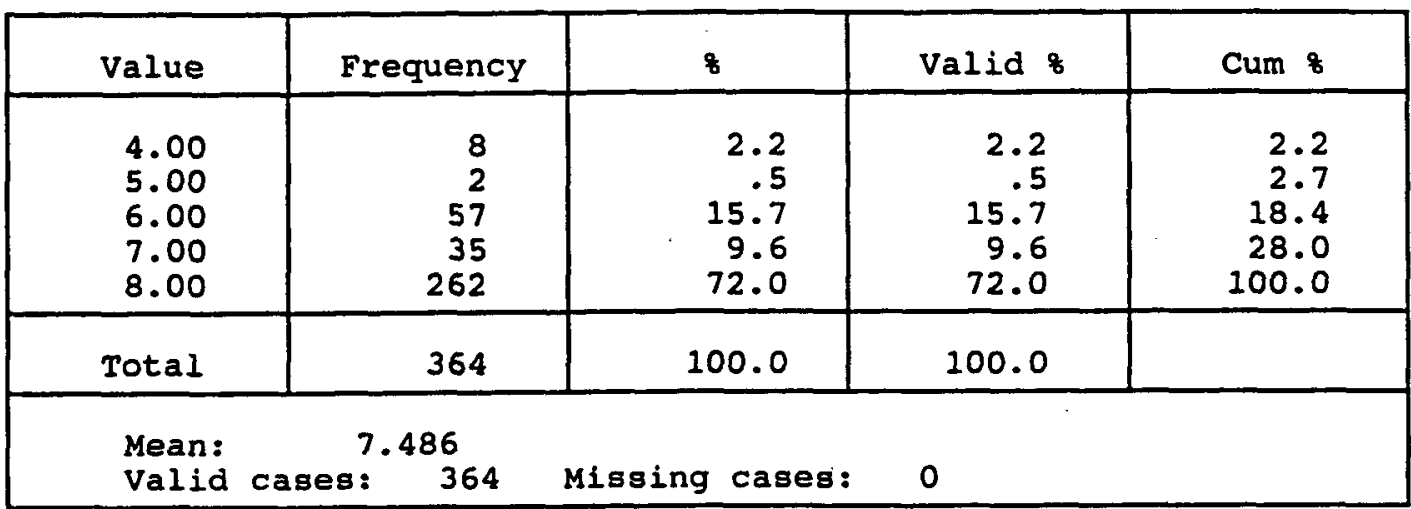

TABLE 37

ADMINISTRATORS DESIRING CHANGE

\begin{tabular}{|c|c|c|c|c|}
\hline Value & Frequency & 8 & Valid \& & Cum \& \\
\hline $\begin{array}{l}1.00 \\
7.00 \\
8.00\end{array}$ & $\begin{array}{l}1 \\
2 \\
6\end{array}$ & $\begin{array}{l}11.1 \\
22.2 \\
66.7 \\
\end{array}$ & $\begin{array}{l}11.1 \\
22.2 \\
66.7 \\
\end{array}$ & $\begin{array}{r}11.1 \\
33.3 \\
100.0 \\
\end{array}$ \\
\hline Total & 9 & 100.0 & 100.0 & \\
\hline
\end{tabular}

whereas any answer higher than 2 means either they are undecided (by 3) or they desire no change (by 4 or 5). My intention is only to underline the significant mean score in each group of respondents: teachers, 3.698 ; parents, 7.486; and administrators, 7.111. Table 38 presents a number of valid observations (listwise) whereby one can clearly see the three groups of variables along with their mean and their standard deviation. 
TABLE 38

DIFFERENCE IN DESIRE FOR CHANGE BETWEEN TEACHERS, PARENTS, AND ADMINISTRATORS

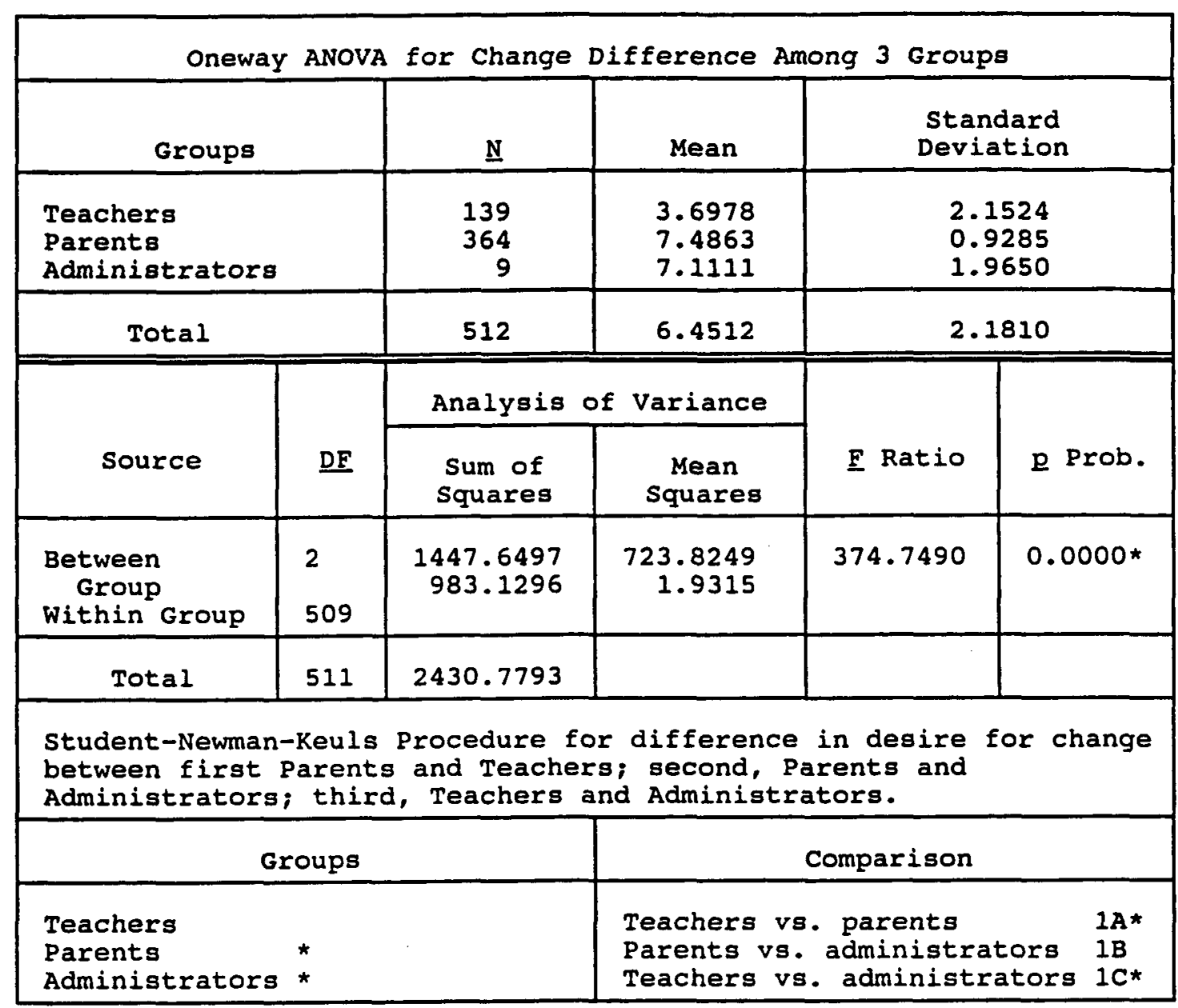

$* \underline{p}=.050$. 


\section{Discussion}

To test hypothesis 1 , a one-way ANOVA test was carried out (see Table 38). A significant difference at 0.05 level is determined. The probability for no difference between each of the three groups taken together 2 by 2 is $\underline{p}=0.0000$. The mean difference, for example, between teachers and parents is $7.4863-3.6978=3.7885$. The mean difference between teachers and administrators is $7.1111-3.6978=3.4133$. The mean difference between parents and administrators is $7.4863-7.1111=0.3752$.

since the three groups in hypothesis 1 are compared, we need a multiple comparison test for a 1 by 1 comparison. Therefore, a student-Newman-Keuls procedure is also carried out (see Table 36, bottom) for hypotheses 2,3 , and 4 .

\section{Testing of the Hypotheses}

In chapter 1, two main questions were presented:

1. What are the perceived concomitant educational problems facing the African American at-risk elementary students in Benton Harbor?

2. Is there a need for change in the Benton Harbor school system?

In addition, in chapter 3 , the two basic questions were set forth with very detailed and precise descriptions in the form of null hypotheses in order to explore thoroughly and to clarify the respondents' 
answers. They are hypotheses $1,2,3$, and 4 .

In chapter 4 , the comments on each question of the questionnaire clearly spell out the fact that the Benton Harbor school administrators, teachers, and parents are not indifferent to the concomitant educational problems of the African American "at-risk" elementary students.

In the testing of the hypotheses they will express their wish. They will signify if there is a significant difference between the implementation of a program for change in all elementary schools of Benton Harbor to satisfy the perceived concomitant educational problems of the at-risk African American students and no change at all. In case there is no difference, the concerned hypothesis is retained, otherwise it is rejected.

\section{Hypothesis 1}

Hypothesis 1 states: There is no significant difference between the parents', teachers', and administrators' perceived concomitant educational problems due to teachers' burnout, lack of discipline, and low academic achievement in reading, mathematics, and science.

In order to test hypothesis 1, which attempts to establish or refute that there is no significant difference for change between the parents', teachers', and administrators' perceived concomitant educational 
problems of those students, the following strategy was adopted. Because the educational hindrance was assessed to be caused mainly by teachers' burnout, lack of discipline, low academic achievement in reading, mathematics, and science, four questions relating to these concerns from each of these three groups were chosen for comparison (see p. 136). One-way ANOVA (Table 38) for change difference among the 3 groups indicates a mean of 3.6978 for teachers; 7.4863 for parents; and 7.1111 for administrators. It simply means that there is a significant difference for change between the 3 groups, consequently the first hypothesis is not sustained.

Hypothesis 2

Hypothesis 2 states: There is no significant difference between parents and the teachers of Benton Harbor elementary schools with respect to the need for change within the school system.

The Student-Newman-Keuls procedure establishes a significant difference for change between the parents and the teachers of Benton Harbor elementary schools at the 0.05 level. A mean difference of 3.7885 is found as $7.4863-3.6978=3.7885$. Teachers do not seem to want the same change as the parents, consequently this hypothesis is rejected.

Hypothesis 3

Hypothesis 3 states: There is no significant 
difference between the parents and administrators of Benton Harbor elementary schools with respect to the need for change within the school system.

The Student-Newman-Keuls procedure establishes no significant difference for change between the parents and administrators of Benton Harbor elementary schools at the 0.05 level.

This has been presented in Table 38. The difference of the means of the two groups denotes pairs of groups not significantly different at the 0.05 level: $7.4863-7.1111=0.3752$. The probability for no difference between the two groups is $p<0.050$. This hypothesis is consequently sustained.

\section{Hypothesis 4}

Hypothesis 4 states: There is no difference between the teachers and administrators of Benton Harbor elementary schools with respect to the need for change within the school system.

The Student-Newman-Keuls procedure establishes a significant difference at the 0.05 level for change between the teachers and administrators of Benton Harbor elementary schools. The difference of the means between these two groups is enormous: $7.1111-3.6978=3.4133$ (see Table 37). The probability for no significant difference between these two groups is $\mathrm{p}>0.050$ as 
$\underline{p}=3.4133 ;$ according to the above calculation. This hypothesis is consequently rejected. 
CHAPTER V

\author{
SUMMARY, CONCLUSIONS, AND \\ RECOMMENDATIONS
}

\title{
Introduction
}

The Benton Harbor area school system has had many problems in dealing with dropouts at the junior and senior high-school level. The large number of students who remain in school now fall under the category of "atrisk" students. Throughout the country statistics abound on the devastating consequences of these or similar "atrisk" youth. In most cases, these dropouts become juvenile law offenders, crime-prone youth, pregnant, and victims of crimes. "Sociogenic brain damage" seems to be at work among these youth. This study has attempted to find out the causes of this juvenile crisis and has proposed some practical solutions to help those youngsters secure a good primary education.

\section{Statement of the problem}

It appears that the majority of the Benton Harbor youth fall in the category of "at-risk" students. They are at risk of dropping out of school, of becoming pregnant, or of becoming involved in criminal action. The 
traditional schools have not been able to handle the problems of these students. In fact, the situation relating to these youth appears to increase with each passing year.

\section{Purpose of the study}

The purpose of this study was to determine the concomitant educational problems facing the "at-risk" African American students in the Benton Harbor elementary school system and to suggest positive changes through an alternative model.

\section{Research Questions}

The following basic questions were addressed in this study:

1. What are the perceived concomitant educational problems facing the African American at-risk elementary students in Benton Harbor elementary schools?

2. Is there a need for change in the Benton Harbor school system?

\section{Hypotheses}

Hypothesis 1

There is no significant difference between the Benton Harbor parents', teachers', and administrators' expressed desire to satisfy the perceived concomitant educational problems due to teachers' burnout, lack of 
discipline, and low academic achievement in reading, mathematics, and science.

Hypothesis 2

There is no significant difference between parents and the teachers of Benton Harbor elementary schools with respect to the need for change within the school system.

Hypothesis 3

There is no significant difference between the parents and administrators of Benton Harbor elementary schools with respect to the need for change within the school system.

Hypothesis 4

There is no significant difference between the teachers and administrators of Benton Harbor elementary schools with respect to the need for change within the school system.

\section{Summary}

This study has proved to be significant and has endeavored to open new horizons to solve the endemic educational dilemma of the inner-city "at-risk" African American youth. It has identified concomitant educational problems of the "at-risk" African American youth of the city of Benton Harbor. It has demonstrated the necessity of urgently modifying the curricula of all 
elementary schools of the city of Benton Harbor. It has added to the sparse literature on educational programs for "at-risk" inner-city African American youth of America. It can be contributory to an academic master plan for the city of Benton Harbor elementary schools. Ultimately, it can be a model for the development of innercity primary schools regionally, and if necessary, even nationwide. The literature for at-risk students in this country has already suggested the creation of unisexed military-type schools as a probable remedy for the social epidemic of unwed teen pregnancy, juvenile law offenders, dropouts, and at-risk teens (Johnson, Maruyama, Johnson, Nelson, \& Skon, 1981). This crisis is created mainly because of absence of self-discipline, too much leisure time, lack of self-esteem, lack of respect for authority figures, and complete disregard for others' property and well-being. This problem can be solved and will be solved for the highest good of society.

\section{Conclusions}

From this study the following conclusions can be derived.

1. Most of the students in the Benton Harbor school system are African American and fall in the category of at-risk for different reasons presented in chapter 4 .

2. Seventy-two percent of the teaching staff 
find it difficult to work satisfactorily with this demographic group of children and consequently leave the school system within 1 to 10 years (Table 6). The difference in ethnicity and background seems to be responsible for this burnout.

3. Sixty-four percent of the teachers say that they are not satisfied in their job. Four percent say they are not satisfied. Eleven percent experience little job satisfaction, and $49 \%$ state that the job satisfaction is fairly tolerable (Table 8). For all practical purposes the three above groups are not satisfied. Consequently, the turnover of $72 \%$ of the teaching staff within 1 to 10 years seems to be directly related to job satisfaction (Table 6).

4. Twenty-nine percent of the teachers state that they have no opportunity in this school system for self-actualization or self-realization and fulfillment (Table 9). This is extremely critical for intellectuals and for every human being, for that matter, according to Maslow's hierarchy of human needs.

5. Forty percent of the teachers believe that the disciplinary measures in the Benton Harbor school system are not adequate (Table 10). Fair and not good are considered as not adequate. This could be another reason why $72 \%$ of the teachers leave the system within 1 to 10 years.

6. In addition to the inadequacy of discipline 
in the classroom (Table 11), the absence of opportunity for self-actualization (Table 9), and students' apparent lack of interest in learning (Table 11) aggravate the teachers' dissatisfaction (Table 8 ) and fuel the teachers' turnover crisis (Table 6).

7. Seventy-seven percent of the teachers state that the students' achievement is average, low, or even very low (Table 12) and seem inclined to blame the students' lack of interest in learning for lack of achievement (Table 11). This sounds like blaming the victim for the crisis.

8. This study concludes that $56 \%$ of the teachers (Table 13) would willingly move to another teaching position in response to these disciplinary problems, students' low achievement, lack of opportunity for selfrealization, and students' apparent lack of interest in learning. They would move even if they were given a decrease in salary of $5-15 \%$. Yes, maybe, and cannot say are considered as positive intention to move.

9. Parents' lack in education may be correlated to the students' educational crisis. Fifty-nine percent of the mothers of students enrolled in the Benton Harbor elementary schools did not complete their high-school program (Table 16). Twenty-six percent of both father and mother did not complete a high-school education (Table 16).

10. Regarding the average time of daily watching 
of television at home, these students fall in the following five categories: $4 \%$, none; $12 \%, 1$ hour or less; $16 \%, 2$ hours; $27 \%, 3-4$ hours; $41 \%, 6$ hours or more (Table 19). Fifty percent of the students watch TV on a daily basis without adult supervision (Table 20). This could possibly contribute to misbehavior or potential violence manifested often in the classrooms at Benton Harbor (Schulz \& Bravi, 1986). Particularly in the early grades, children try to copy the negative behavior seen on TV (Friere, 1980).

sixty-eight percent of the primary-school students watch TV between 3 and more than 6 hours per day (Table 19). This pattern indicates very little time left for homework and personal study.

As socrates argued, the teacher is the leader of civilization with an absolute responsibility to pursue truth despite how one's contemporaries oppose or abuse him or her. The teacher's ultimate function is to stir the thinking of average individuals, shake them out of their lethargy, straighten out their irrationality, and drag them out of the cave of tribal superstition. of course, a social value ultimately emerges from such education since society is changed for the better when morality and intelligence are combined (Toynbee, 1947).

\section{Recommendations}

Based on the review of literature presented in chapter 2 of this study and based on the findings 
presented in chapter 4 , two kinds of recommendations are presented:

1. General recommendations for consideration.

2. Recommendations for further study.

General Recommendations

1. In view of the fact that most of the students fall in the category of at-risk, it is recommended that the pupil-teacher ratio be no more than 15 to 1 . This will enable the teacher to more easily handle the endemic disciplinary problems and more adequately provide much needed help to the students.

2. Taking into account that $72 \%$ of the teachers leave the system within 1 to 10 years (Table 6), it is recommended that remedial steps to increase staff retention be taken by the administration. Constantly recruiting of new staff proves to be extremely costly to the district, but it should be used to bring more minority teachers in order to correct the serious racial imbalance in staff.

3. Eighty-nine percent (Table 23) of the African American parents in Benton Harbor see education as a means to control and shape the destiny of their children. For the great majority of these parents, education is the most valuable legacy they are able to leave for their children (Table 23). Therefore, they see it as a vehicle to upward social mobility par excellence (Table 24). It 
is recommended that the parents be properly counseled to become positive role models in leading, securing, and encouraging their children to get an education.

4. It is also recommended that parents provide early childhood education that is so critical in the mental and social development of preschool children. They may accomplish this parental task through Headstart and other available social services. They approved this proposition at $100 \%$ (Table 27, items 2 and 3 ).

5. It has been found that the unmarried teenage mothers' pregnancy epidemic present in the whole nation reached the alarming proportion of $38 \%$ in Benton Harbor in 1993, according to social services record. It is consequently recommended by $82 \%$ of the respondents that compulsory classes on family planning along with child care, be provided from grades 6 to 12 in Benton Harbor (Table 28, items 4,5 , and 6).

President Clinton (1995) recognized this social epidemic and requested that the states do everything possible to solve this national problem.

6. It is recommended that the Benton Harbor school system consider providing year-round education to its clientele. This is a remedial step to cure the summer violence and idleness. This may be implemented with the integration of work experience with the core curriculum (Table 29, item 13). 
What we need strive for is some structure in the life of these youngsters. As one of my secondary-school mathematics' teachers (Elie Henry) used to say: "A little discipline in the life of any human being suffices to make of him/her at a certain given point in time a force."

\section{Recommendations for \\ Further study}

1. It is suggested that further study should be conducted to find out if special schools whose curriculum is based on self-reliance, self-discipline, self-esteem, work-study programs and job-training opportunities are deemed necessary for teenage unwed mothers and juvenile law offenders of the Benton Harbor school system--this with a sincere commitment not to mistreat but to help these young underprivileged students. These special schools should primarily stress the important role of games and exercise in education, favoring praise and reward rather than even mild discipline to accomplish the goals underlined above.

\section{Since it has been found that military} discipline may change the behavior of the at-risk students (Johnson et al., 1981), it is further suggested that Benton Harbor school system cooperate with the military and the state of Michigan to bring about the desired discipline, particularly for the juvenile delinquent youth who come back into the system after 
serving time in the juvenile centers. Special unisex military boot camps should be established for those early law offenders with a rigorous curriculum, emphasizing personal discipline, respect for authority, respect for others' property, good citizenship, and the important role of games and exercise for any desired outcomes.

3. Since the first tenet of any type of education is discipline and as it has been found that a personal lack of discipline is one of the main reasons that the Benton Harbor school system students are at risk, it is further suggested that special unisexed schools be established throughout the Benton Harbor school system to provide for "at-risk" unwed teen mothers and early law offenders with a rigorous military type of discipline.

However as said, Baldassare Castiglione speaking about "the Renaissance man"--the man who would make his way successfully into the highest ranks of society must now be not merely or necessarily nobly born, though that is an advantage, nor a great warrior, though he should be skilled in arms, but a fully developed personality, an amateur of all arts and all branches of learning and a master of some, possessing above all, grace, tact, good manners and personal charm. (Furgerson \& Bruner, 1969, p. 311)

This necessarily will be costly, but much less costly to American society than constructing prisons to keep (with the taxpayers money) for years thousands upon thousands of young people who should be preparing themselves for useful life in that society. 


\section{Overview of a Research-Based \\ Plan for Reform in Benton \\ Harbor Schools}

Robert E. Slavin (1996), speaking about students with special needs, narrates a little story which seems to be appropriate to the youngsters in the Benton Harbor elementary school system.

once upon a time, there was a town whose playground was at the edge of a cliff. Every so often a child would fall off the cliff. Finally, the town council decided that something should be done about the serious injuries to innocent children. After much discussion, however, the council was deadlocked. Some council members wanted to put a fence at the top of the cliff, but others wanted to put an ambulance at the bottom. In this parable, says slavin, the idea of putting an ambulance at the bottom of the cliff clearly is foolish on many levels. Waiting for innocent children to be injured and only then providing them with help is cruel and inhuman if the damage can be prevented. Further, it is needlessly expensive; an ambulance costs far more than a fence.

At the end of the introduction repeated at the beginning of the 5 th chapter the researcher says that this study has attempted to find out the causes of this juvenile crisis and has proposed some practical solutions to help those youngsters secure a good primary education. 
Yet longstanding policies in special education at Benton Harbor school system, especially for children with learning disabilities, are very much like this illconsidered idea. Benton Harbor schools provide pretty good programs in kindergarten, 1st grade, and beyond, but they know with certainty that a number of innocent children will fall by the wayside. In particular, a certain number of children of normal intelligence will fail to learn to read. After a while, these children are very likely to be retained, assigned to long-term remedial services, or labeled as having specific learning disabilities and provided with special education services.

By the time these services are rendered, most of the children will already have realized that they have failed at their most important task--learning to read. Accordingly, they likely will have lost much of their early motivation, enthusiasm, and positive expectations. Schools will be paying for years--in special education and in remedial instruction costs--for failing to ensure that students succeed in the early years. Research after research has proven that with appropriate prevention and intervention, nearly all children in the early elementary grades can learn to read well (Bear, clever, \& Proctor, 1991; Campbell \& Ramey, 1994; Silver \& Hagin, 1990; Zigler, Finn-Stevenson, \& Linkins, 1992). 


\section{Stopstreaming: Does It Work} for Your Students?

Today, in the Benton Harbor school system, most children with "learning disabilities" are mainstreamed for much of their school day. Mainstreaming is better than self-contained placement, but it is far from ideal. Mainstreamed students with academic deficiencies often are poorly accepted by their peers, struggle with academic content, and develop low self-esteem (Bear et al., 1991).

Obviously students fare better when they succeed the first time they are taught, thereby avoiding both special education and mainstreaming. Slavin et al. (1991) call this neverstreaming: implementing prevention and early intervention programs powerful enough to ensure that virtually every child is successful in the first place.

Few people would deny that this is a nice policy in concept. The question is, would it be practical with real students in real schools? Evidence is accumulating that it is in fact possible to ensure the success of almost all children in the early elementary grades--at least in reading. And this has profound implications for special education for children with reading disabilities. The evidence produced by several researchers can be considered as follows and all these policies may be applied to the Benton Harbor school system. 
1. Success for All Program:

The strongest evidence for the feasibility of neverstreaming comes from the research of Slavin, Madden, Karweit, and Dolan (1996), a comprehensive approach to restructuring elementary schools. The Johns Hopkins University's Center for Research on the Education of students Placed at Risk (CRESPAR) is implementing the program in more than 300 schools in 70 districts in 24 states. The focus is prevention and intensive early intervention for children in preschool through sixth grade.

As preventive measures, the success for All

Program provides research-based instruction in reading, writing, and language arts. The programs emphasize cooperative learning and maintain a balance among phonics, children's literature, creative writing, and home reading. These programs are backed up in each concerned school district by offering:

a. intensive professional development for teachers

b. a full-time building facilitator to help teachers continue to improve their instructional strategies

c. a curriculum-based assessment program to monitor student progress and identify children in need of additional help, and

d. a strong parent involvement program. However, even the best instructional programs cannot 
ensure success for every child. For this reason, success for All schools provide one-to-one tutoring for 1st graders who are struggling in reading. The tutors typically are certified teachers. Their goal is to see that the students never become remedial readers. To do this, they provide students with instruction that is closely tied to classroom reading instruction and teach them megacognitive skills--for example; how to ask themselves whether what they read makes sense and relates to what they have been taught.

A family support team in each school also provides intensive early intervention. (Table 27, item 12). Team members get parents involved and give them strategies for helping their own children. They also develop programs to improve attendance, resolve behavior problems, and work with local agencies to see that children have eyeglasses, hearing aids, health services, or other needed assistance (Table 30, items $15 \& 18$ ).

Research on Success for All (Slavin, Madden, Karweit, Dolan, \& Wasik, 1992; Slavin et al., 1994; Madden, Slavin, Karweit, Dolan, \& Wasik, 1993) has shown that the program has consistently improved children's reading skills, as measured by both individually administered reading tests and standardized assessments. students in nine school districts across the United states have average scores three months ahead of those of matched control students by the end of first 
grade, and more than a year ahead by the end of fifth grade. The effects are particularly dramatic for students who are more at risk, those in the lowest quarter of their grades.

These findings have direct relevance to special education. A longitudinal study in very high-poverty Baltimore schools found that of third graders participating in the program, including those in special education, only $2 \%$ were performing 2 years below grade level, the usual criterion for identifying reading disabilities. In the control groups, by contrast, $9 \%$ of third-graders were performing this poorly (Slavin et al., 1992). overall, special education placements were cut in half. In a study conducted in Ft. Wayne, Indiana, Smith, Ross, and Casey (1994) found that special education referals in grades $\mathrm{K}-3$ were more than three times higher in control schools than in success for All schools. Smith and colleagues also found that firstgrade special education students in Success for All schools had substantially higher achievement than 1st graders in control schools (Smith et al., 1994).

Success for All is usually funded by reallocation of Title I funds, supplemented on occasion by special education funds. Very few schools in the inner-city areas have funding beyond what they would have had without the program (Slavin et al., 1992). This means that even without extra resources, Benton Harbor 
elementary schools can substantially reduce reading failure. With additional resources to pay for more tutors, they can further reduce the number of children failing to meet adequate reading standards.

2. Reading Recovery: a must in Benton Harbor elementary schools.

Reading Recovery is a first-grade tutoring program being used successfully in thousands of U.S. schools. It was developed in New Zealand by Marie Clay (1985), and researched and disseminated in the United States by Gay Su Pinnell, D. E. DeFord, and C. A. Lyons at Ohio State University (1988).

The program provides 30 minutes of daily, one-toone tutoring to 1st graders who score poorly on a battery of diagnostic tests. Tutors are certified teachers who complete an extensive professional development program.

As with Success for All, research on Reading Recovery shows that the vast majority of children can be well on the way to reading effectively by the end of 1 st grade (Pinnell et al., 1994). Reading Recovery students are more likely than matched comparison students to stay out of special education (Lyons, 1989).

3. Prevention of Learning Disabilities.

As the name suggests, Prevention of Learning Disabilities is designed to keep children from ever needing special education services for learning disabilities (Silver \& Hagin, 1990). Like Reading 
Recovery, this program provides one-to-one tutoring to at-risk first-graders. The tutoring, however, focuses on general perceptual skills as well as reading (Table 31 item 26). Studies of the program have found that firstgraders have substantially higher achievement than do similar control groups (Silver \& Hagin, 1990).

4. Early Childhood Intervention.

The Carolina Abecedarian Project (Campbell \& Ramey, 1994) is the best example of an intensive early intervention program (Table 27, items $1,2, \& 3$ ). Research on this program has found that following children through the critical first 5 years of their lives has strong and lasting effects.

Reading Recovery and Prevention of Learning Disabilities start with children in first grade, and Success for All starts with 4- and 5-year-olds. Yet much of children's cognitive development has already taken place by age 4 (Carnegie Corporation, 1994). This project offers further evidence that if young children grup in poverty are effectively stimulated and their parents are helped to create a healthy home environment, they are more likely to perform well in school and to stay out of special education.

5. Family Support and Integrated Services.

Two national programs designed to improve schoolhome collaboration and services for children in the early grades are Comer's (1988) School Development Program and 
Zigler's Schools of the 21st Century (Zigler et al., 1992). The programs aim to head off the causes of school failure that have nothing to do with children's cognitive capabilities: conflicts between parents' and schools' values and expectations; erratic attendance; or the need for eyeglasses, hearing aids, or more adequate nutrition, for example. Family support and integrated service programs can solve many of these problems.

Summary: The Verdict Is in for Benton Harbor Elementary Schools

Up to now, no one program has been able to ensure that all children are reading well enough to stay out of special education. However, the five programs described above have come close, and with additional research and experience are sure to come even closer.

Moreover, imagine what would happen in Benton Harbor if all children in need of early intervention participated in multiple programs as intensive and comprehensive as these, from preschool through the elementary grades. The number of children still having reading problems would almost certainly be a fraction of what it is today.

A useful and appropriate debate is going on about special education versus inclusion for children with more serious, low incidence disabilities. For children at risk of learning disabilities, however, neither of these alternatives is the answer. Instead the need to focus on 
prevention and early intervention seems to be wiser and less costly on the long range. If it is known and it is known how to ensure that virtually every child will become a skillful, strategic, and enthusiastic reader, then it is criminal to let children fall behind and only then provide assistance. Neverstreaming, stopstreaming, or special education should be the goal for all children who are at risk.

In the light of the fact that nationwide more African Americans (40\%), Hispanics (38\%), and Native Americans $(42 \%)$ were at risk than White $(20 \%)$ or Asian (20\%) children. More males (29\%) were at risk than females $(21 \%)$. Older students $(32 \%)$ were more at risk than younger students $(21 \%)$, and students in certain schools and certain communities were more at risk than students in other schools and communities (Frymier, 1989). Since Benton Harbor schools and community, according to school authorities (Ellington, 1990) double the national average with $80 \%$ African American children at risk, it is imperative that the school district adopt the remedies which nationwide work. It is imperative and morally urgent that this district build a double fence to prevent innocent children from continually falling off the cliff of the educational playground. 


$$
\text { A P P E N D I C E S }
$$


APPENDIX A

QUESTIONNAIRE 


\section{Questionnaire: Section I (Teachers only)}

\section{Teacher Questionnaire}

1. Grade taught

2. Years of teaching experience

1-5 years 5-10 years 10-20 years above 20 years

3. Years in this school

4. What is your level of satisfaction with your teaching job?

not satisfied

- little satisfied

- so-so

- satisfied

- very satisfied

5. Which of the following, in your opinion, gives more job satisfaction? (Rank in order of priority from 1-5).

high salary

- students' high achievement

- work security

- excellent working conditions

- feeling of self actualization

6. How would you rate the discipline in your school?

not good
$-\quad$ fair
$\square$ good
very good

7. In your opinion, what are the main factors responsible for undiscipline in the classroom? (Check more than one)

Students' low self-esteem

- Family values predominate

- Lack of interest in learning on the students' part

- Poor methodology uses

- Students' instability and emotional problems 
8. How would you rate your students' academic achievement compared with the national average?

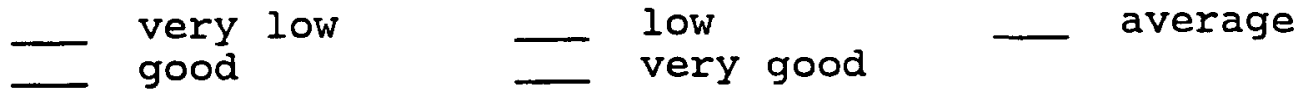

9. If you were offered a teaching position in another school where the discipline and the students' academic achievement are rated as "very good" but with a salary 5-15\% lower, would you accept?

yes

no

maybe

cannot say 


\section{Questionnaire: Section II (staff and classroom Teachers only) \\ Information Related to students and Parents}

1. Grade Level

2. Number of students

3. Ethnicity
(a) White
(b) $\longrightarrow$ Black
(c) - Hispanic
(d) - other

4. Family setting
(a)
students living with natural parents, mother and father
(b)
(c) $=$
(d)
students living with grandparents
students living with mother and stepfather
students living with mother only
students living in foster home

5. Education
(a)
Mother not graduated from high school
(b)
Mother with high school education
(c) - Mother with college education
(d) - Neither parent graduated from high school
(e) - Both parents with high school education
(f) - Both parents with college education
(g) - Families getting newspaper regularly
(h) - Families with a set of encyclopedias at home
(i) - Families with more than 25 books at home
(j) - Families getting any magazines regularly

6. Lifestyle

A. Television

How much television do students usually watch each day?
(a) none
(b) -1 hour or less
(c) 2 hours
(d) $-3-4$ hours
(e) $-5-6$ hours 
B. TV Supervision

(a) - Students with an adult when watching TV

(b) - students with adult who chooses what they want to watch

c. Bed-time supervision

(a)

Students whose parents set a time to go to bed

(b) Students who go to bed as they please

D. School Work

students reading with or to their parents on a regular basis:
(a)
Almost every day
(b) - once or twice a week
(c) - once or twice a month
(d) - Never or hardly ever

students discussing things they have studied in school with someone at home:
(a)
(b) - once or twice a week
Almost every day
(c) - once or twice a month
(d) - Never or hardly ever

E. stability

students who have been in the same school since kindergarten

Students who have been in three or more schools from $\mathrm{K}-4$

students who have been in three or more schools from $\mathrm{K}-6$ 


\section{Questionnaire: section III}

Parents only

1. As African-American parents do you see education as vital in the struggle for freedom and full equality for your children in America?
(a) - Not really important
(b) - Its importance increases day after day
(c) - It is actually the most important asset
(d) It is not necessary for success in life

2. As African-American parents do you see education as a vehicle by which your children can control and shape their destiny, build stable communities, provide for their families, and fully realize the fruits of democracy?
(a) - Yes, I am fully convinced
(b) - Yes, but I think it is better to have money than education
(c) No, education is not for our people
(d) - No, my children rather need a good job
(e) - No, why must my children have an education more advanced than us?

3. As African-American parents do you favor good reading skills and excellent mathematic ability for your children?
(a) Yes, I do because they are basics
(b) - No, I do not because they are not important to me
(c) Yes, I strongly recommend these two subjects for our young people
(d) No, if they have money and a good job, those things are secondary
(e) No, I do not see why they have to torture their mind to learn Mathematics, that is very difficult

4. Do you think that quality affordable full-time infant and preschool care and education are important?
(a)
Yes, I do because our children need to get off to a good educational start 
(b) - Yes, I do because the finest high school and college programs are useless if our students first do not get a solid grounding in the three "Rs"

(c) Yes, I do because the children who have a good mastery of the three "Rs" are more confident and develop better self-esteem

(d) - No, because I do not believe that preschool care and education have anything to do with how the children will fare in later years 
Questionnaire: section IV

Educational Administrators and National Experts only

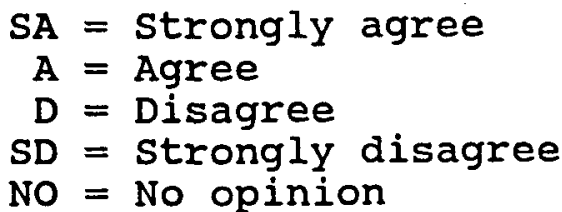

As educational administrators or national experts in the areas of at-risk students and academic academy-type programs do you think it is necessary to implement the following programs in Benton Harbor?

No.

Item

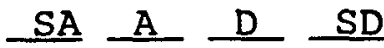
No

Child Intervention:

1. Child care programs so that teenage and other "at-risk" mothers may attend school

2. Quality preschool for three and four year old youngsters, based on an active learning curriculum, and to provide health and other support services

3. Quality school age child care programs for low income working parents, to include development of language and social skills and school readiness experiences

Parent Intervention:

4. Program alternatives and work incentives (partnerships with business and industry must be explored) to assist teenage and "at-risk" parents to complete high school

5. Programs to focus on parenting skilis for teenage and "at-risk" parents to include health care, nutrition and intellectual stimulation for young children 
No.

Item

6. Pre and post natal health care for pregnant teens and high risk mothers

Management:

7. School based management, participatory decision making and local accountability for improvements

8. Staff development programs for administrators and teachers to enable them to work with citizens of the 21st century

9. Use of existing facilities to create smaller school enrollments and smaller classes

10. Partnerships and shared decision making with business and industry to accomplish Program \#4

11. Partnerships with physical and mental health care providers to accomplish Program \#2 and \#5

12. Use of electronic student record transfer systems (MESRTS) in metro areas

13. Year around and flexible scheduling to accommodate community and maximize facility usage

Program:

14. Fluid curriculum to provide Reading and Math basic skills and survival strategies for citizens of 21 st century

15. Early intervention programs: affordable full-time infant and preschool care; pre-natal classes, academic instruction, counseling, health and social services, and parenting classes

SA A D SD NO
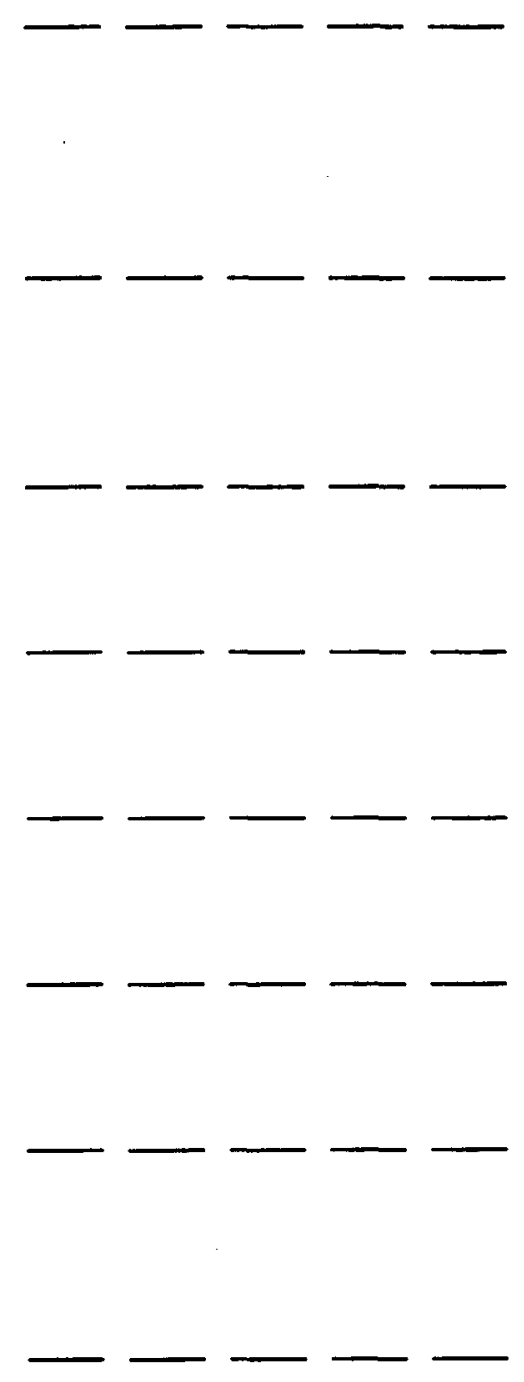
No.

Item

$S A \quad A \quad D \quad$ ND

16. Incorporation of teaching and use of technology: video disks, computers, robotics, etc.

17. Use of alternative programs to integrate work experiences with core curriculum

18. Programs providing health services, nutrition, education and career and family counseling specifically targeted to "at-risk" families

Extracurricular:

19. Alternative activities, developed with community assistance, to stimulate development of physical and social skills, appreciation of arts and environment

20. Utilize cooperative planning with community to include programs for Iife long learning, and activities for youth, adults and seniors

21. Programs to encourage volunteerism: students, adults, corporate sector, grandparents, etc.

22. Provide educational programs which enable all its primary school students to learn interactively in dyads or small groups, experientially, and in roles that are both supportive of one another and that emphasize prior life experience as germaine to mastering new content.

23. Craft educational experience whereby learners talk through required processes to have their questions answered, and to understand that they are valued, "seen," and appreciated for their interactive and selfawareness capacities. 
No.

Item

SA A D SD NO

24. A cooperative environment, one that recognizes and awards the consciousness of individual differences, and one that "celebrates mistakes" as a way of converting confusion and anxiety into a readiness to benefit from trial and error experimentation.

25. Provide a friendly and supportive and non-crowded classroom where the students can ask for and give help; where are action, interactive activities, games, and opportunities to meet with, speak to, and make friends of everyone (teachers included).

26. Recognize the a propos of Edmond's statement which states: "We can, whenever and wherever we choose, successfully teach our children whose schooling is of interest to us. Whether we do it must finally depend on how we feel about the fact that we haven't done it so far;" and strive to apply it to the benefit of BHAS system.

27. Learning environments that emphasize drill and practice, the practical, the applicable, the manipulable, the immediately correct or most defensible answers, immediate feedback on performance, and an efficient workplace.

28. An environment that promotes sequence, reasons, impersonal problem solving processes, objectivity, correct and defensible responses, and intellectual challenge. 


\section{Questionnaire: section $\mathrm{v}$ \\ Parents, Educators, National Experts in the Areas of Alternative Education}

Instructions: In this section write any additional suggestions and comments you may wish to make. You may wish to list some courses or programs you will like to see implemented at BHAS primary school system to help meet the educational needs of the "at-risk" as well as not "at-risk" elementary school African-American youth of the city of Benton Harbor.

Matthew stevens believes that the most deadly disease ravaging the African-American and Latino communities today is mediocrity. "We are what we repeatedly do. Excellence is not an act, but a habit" (Aristotle). According to James Comer this mediocrity is not just a matter of parents not caring enough, teachers not making enough of an effort, and kids not being motivated. It is more complicated than that. It is a combination of changing the nature of the economy that created the instability of family and community and also raising the level of development necessary to help more people participate in the economy.

1. How do you see we can alter the ethos of our institutions to create this liberating movement? 
In "Freedom Plow," Langston Hughes reflects: "When a man starts out to build a world, he starts first with himself and the faith that is in his heart, the strength there, the will there to build." These strong words illuminate the motivational forces that must be engaged in our efforts to educate students and financially liberate their parents who are starting out with "their hands empty." Unless our schools and colleges harvest this vast neglected human resource, the American way of life will vanish in our lifetime, writes John F. Noonan, president, Bloomfield College.

2. How do you yourself plan to help America build its new world and harvest this vast, neglected human resource?

It is obvious that unemployment is the major contributing factor toward poverty. What is not so well appreciated is that jobs not only provide income, but also enhance selfesteem, education, and aspiration in families. Perhaps the most disheartening thing about America is that poverty has become so built into the system that it becomes a deeper and deeper hole for many African-American families with every succeeding decade. Thus, poor families of the 1960 s and 1970 s are more likely to have offspring who are poor in the 1980 s and even poorer in the 1990s.

3. Do you think as a society all together we can reverse this shameful circle? 
APPENDIX B

\section{CORRESPONDENCE}




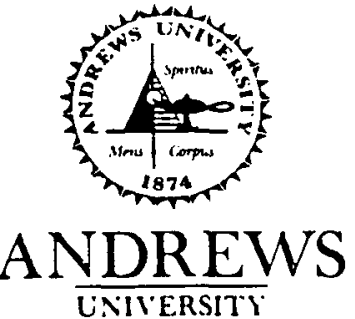

June 12, 1991

State Commissioner of Education Maine

Dear Sir:

Re: Solicitation of a list of Academic academy for research purposes

Many "at risk" children are failing before they ever enter schools. Poverty, poor nutrition, and lack of health care contribute to a never ending cycle of impaired cognitive development, learning problems and failure in the early grades.

We are almost certain that your state is nol exception in this matter. Would you be kind enough to let us have a list of the Academic Academy; the modified type of primary school implementing alternative curricula in your state in order to alleviate the plight of those mainly black youth and other minority youngsters in this regard.

Kindly supply a list, with the name of the contact person, of such alternative schools now operating in your state.

Yours truly,

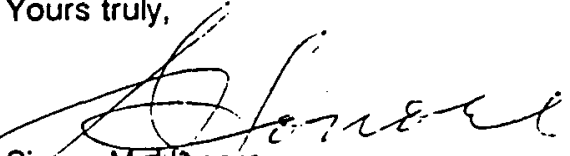

Simon MFHonore

Doctoral Student,

Dept. of Educational Administration

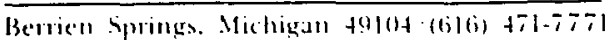




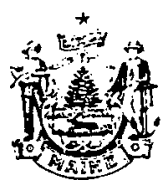

John R. Mikernan, Jt Governor

DEPARTMENT OF EDUCATION

Eve M. Bither Commissioner

Telephone (207) 289.5800

June 17, 1991

Mr. Simon Honore

Department of Education Administration

Andrews University

Berrien Springs, Michigan 49104

Dear Simon:

Your letter of June 12, 1991 to the Commissioner of Education has been forwarded to my office for response. Please find the following materials enclosed:

Maine Dropout Prevention Planning Guide Advisory Committee Report to the Joint Education Committee, January 1991

If you need further information, please feel free to contact me at (207) 289-5110.

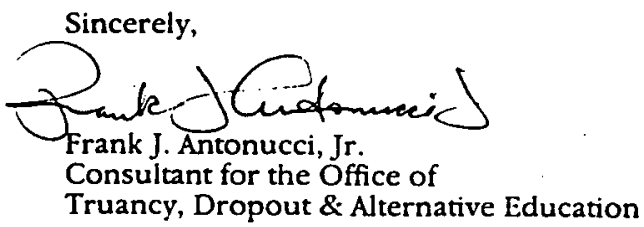

$\mathrm{FJA} / \mathrm{stp}$

State House Station 23, Augusta, Maine 04333 - Offices Located at the Education Building

An Equal Opportuntry Employer 
Diana J. Ohman

Superintendent of Public Instruction

Wyoming Department of Education

307/777-7675

307/777-6234 FAX

Hathaway Building, Second Floor $\bullet 2300$ Capitol Avenue $\bullet$ Cheyenne, WY 82002-0050

June 19, 1991

Simon M. Honore, Doctoral Student

Department of Educational Administration

Andrews University

Berrien Springs, Michigan 49104

Dear Mr. Honore:

Per your letter of June 12, 1991, those alternative schools now operating in Wyoming are:

- Campbell County Alternative/Transitional Center, Gillette, Les Hellevang

- Alternative School, Riverton, Mike Kouris

- High School Three, Cheyenne, Gil Sanchez

- Roosevelt Center, Casper, Dr.Carl Madzey

- Alternative High School, Rock Springs, Robert Plant

- Western Wyoming Alternative School, Jackson, Albert Storrs

Hope this information is helpful.

Sincerely,

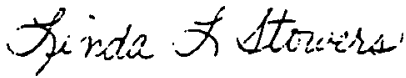

Linda L. Stowers, Director

School Improvement Unit

$\mathrm{LLS} / \mathrm{kp}$ 


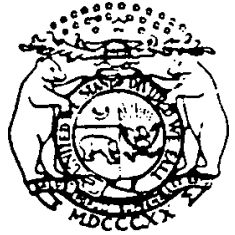

DEPARTMENT OF ELEMENTARY \& SECONDARY EDUCATION P.O. BOX 430

IEFFERSON' CITY, MISSOURI 05102

June 20, 1991

Mr. Simon M. Honore

Doctoral Student

Department of Educational Administration

Andrews University

Berrien Springs, Michigan 49104

Dear Mr. Honore:

Thank you for your letter of June 12, 1991, requesting information on alternative schools in Missouri. I will share your letter with Mrs. Joan Solomon, Director of Urban Education in our Department. Mrs. Solomon also chairs our activities related to at-risk students and she may know of specific alternative schools which may be of interest to you. By copy of this letter to her, I will ask that she contact you directiy.

Good wishes.

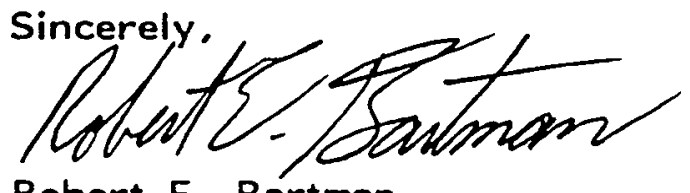

Robert E. Bartman

Commissioner of Education

Iw

c: Joan Solomon 


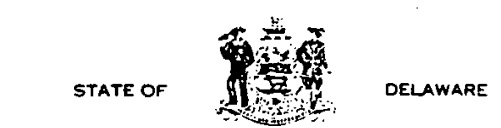

DEPARTMENT OF PUBLIC INSTRUCTION

THE TOWNSEND BUILDING

P. O. BOX 1402
DOVER. DELAWARE 19903.1402
JAMES L. SOARTZ INTERIM STATE SUPERINTENDE':T
ROBERT E SCMILLER

JAMES L. SPARTZ

DePuTY STATE SUPERINFENDENTS

PRIMO V. TOCCAFONOI

ASSISTANT STATE SUPERINTENOENT

June 21,1991

Simon M. Honore

Dept. of Educational Administration

Andrews University

Berrien Springs, Michigan 49104

Dear Mr. Simon Honoré:

In response to your request of June 12, 1991, Delaware State College (Contact: Dr. William B. Delauder, President, 1200 duPont Highway, Dover, DE 19901) may provide you with information on their academic intervention programs for underrepresented youngsters.

Should you require additional information, please do not hesitate to call me. Good luck with your research.

sincerely

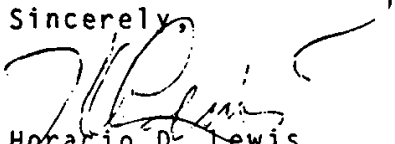

Horacio" D? Lewis

State Supervisor

cc: Dr. Carol O'Neill Mayhew 
ROBERT E. BARTMAN

Commissioner of Education

(314) 751-2931

\section{DEPARTMENT OF ELEMENTARY AND SECONDARY EDUCATION P.O. BOX 480 \\ JEFFERSON CTTY, MLSSOURI 65102-0480}

June 24, 1991

Mr. Simon M. Honore

Doctoral Student

Department of Educational Administration

Andrews University

Berrien Springs, Michigan 49104

Dear Mr. Honore:

Your letter requesting information on primary schools that are implementing alternative curricula to alleviate the plight of minority youngsters was referred to me by Commissioner Robert Bartman for reply. Enclosed is a brochure explaining the Missouri Accelerated Schools Project, a project serving 10 elementary schools in the state. The schools and their contact people are listed on the back of the brochure. I have marked in yellow, for your information, those schools whose population is almost entirely minority children.

Bet wishes on your research project.

Sincerely,

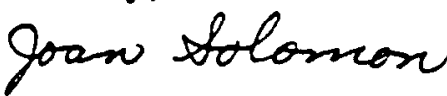

Joan Solomon, Director

Urban Education

csh

Enclosure

c Commissioner Bartman 


\section{STATE OF LOUISIANA DEPARTMENT OF EDUCATION \\ P. 0. BOX 94064 \\ BATON ROUGE, LOUISIANA 70804-9064}

June 24,1991

Mr. Simon M. Honore

Department of Educational Administration

Andrew University

Berrien Springs, Michigan 49104

Dear Mr. Honore:

Thank you for your recent letter concerning elementary alternative schools. I am pleased to provide you with the attached information regarding Louisiana's schools.

Please contact Mrs. Karen Soniat of my office at (504) 342-3355 should you have further questions.

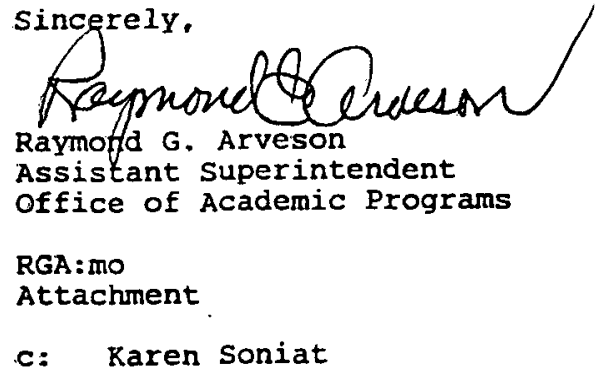

"An Equal Opportunity Employer" 


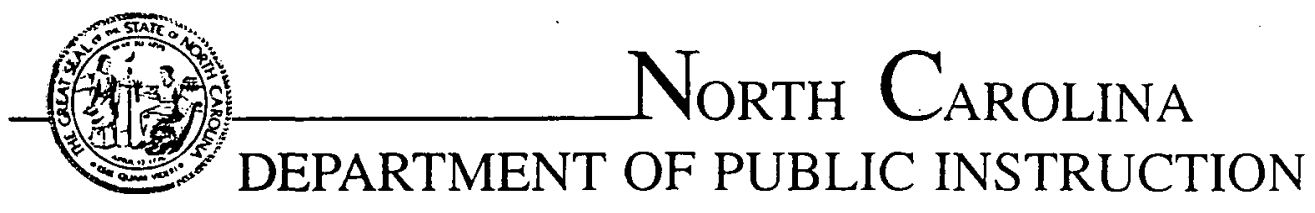

116 West Edenton Street, Education Building Raleigh, NC 27603-1712

BOB ETHERIDGE

State Superintendent

Junc 24, 1991

Simon M. Honore

Doctoral Student

Andrews University

Department of Educational Administration

Berrien Springs, Michigan 49104

Dear Mr. Honore:

Enclosed please find some information on various alternative classes. programs and schools that have been implemented here in North Carolina.

Please let us know if we can be of further assistance.

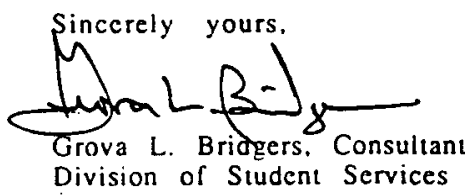

GLB:pt 


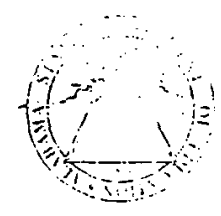

Wayne Teague

State Superintendent of Education

\section{State or Alabama \\ Department of Education \\ Gordon Persons Building \\ 50 North Ripley Street \\ Montgomery, AL 36130-3901}

June 24, 1991

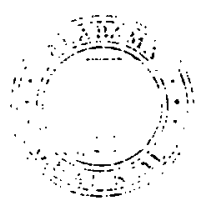

"Promoting Excellence in Alabama's Schools"

Mr. Simon M. Honore

Department of Educational Administration

Andrews University

Berrien Springs, Michigan 49104

Dear Mr. Honore:

Thank you for your letter concerning "high risk" children in Alabama. We understand that poverty, poor nutrition and lack of health care are major problems in the development of a child's cognitive development and contributes to failure in the early grades.

Historically, Alabama's schools have been underfunded. Because of such funding problems there is little money for children in this regard. Alabama doesn't have an altemative curricula or specific legisiation designed for "high risk" children. However, the "Educational Improvement Act of 1991," currently pending in the Legislature, has a section dealing with "at-risk" students (Section 18). A copy of Section 18 is enclosed. Every school system also has special education programs which aid children with learning problems.

In 1988, the state Board of Education required each local school system to establish an altemative program for "at-risk" children. There are no state guidelines for these programs, and thus they may vary in format from system to system. However, standards relating to alternative programs will be incorporated into our performance-based accreditation system, which we are in the process of implementing. Also, there currently is no state funding appropriated for these alternative programs, and local school systems must fund them from various sources.

Chapter 1, a federally funded program, provides remedial and instructional programs to educationally disadvantaged children and youth. For more information on this program in Alabama, contact the state coordinator for Chapter 1, Cecil Bobo, at (205) 242-8199.

Enclosed you will find a copy of the state Department of Education's annual report. Pages 15-16 will explain our requirements for school guidance and counseling to assist with a number of problems, including those of "at-risk" youth. If you need further information about guidance and counseling programs, please contact the coordinator for Counseling and Career Guidance, Jimmy Jacobs, at (205) 242-8049.

If you should need additional information, please feel free to contact our department again.

Sincerely,

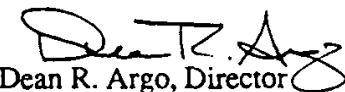

Information and Communications Division

DRA/sl

Enclosures (2) 


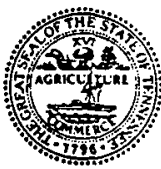

TENNESSEE

STATE DEPARTMENT OF EDUCATION

OFFICE OF COMMISSIONER

NASHVILLE, TENNESSEE 37243-0375

June 26.1991

Simon M. Honore

Doctoral Student

Department of Educational Administration

Berxien Springs. Michigan 49104

Deax Mr. Honore:

In answer to your request for information regarding programs for Children-at-Risk. we are remitting the enclosed data.

I hope this will prove helpful to you, and, If we in

Tennessee can be of further assistance. please let us know.

Sincerely.

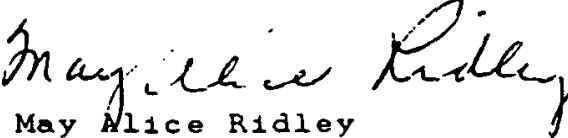

Executive Administrative Assistant

to the Commissioner of Education

MAR : pg

Enclosure 
STATE OF OHIO DEPARTMENT OF EDUCATION COLUMBUS $43266-0300$

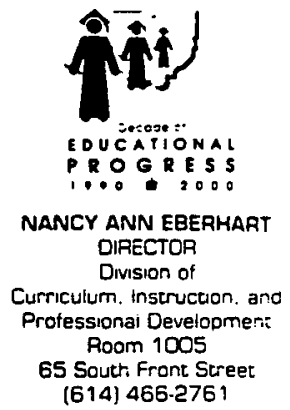

Thank you for your request for the Ohio Educational Directory. Due to the tremendous number of orders this year, the supply has been depleted, and we cannot fill your order. Your check or money order is being returned.

He appreciate your interest and would like to add you to our list of those who will be notified when the 1991-1992 0hio Educational Directory is available. At that time, you will receive current information about directory cost and shipping charges. Please fill out the form at the bottom of the page and mail it to

Ohio Educational Directory

Ohio Department of Education

Division of Curriculum, Instruction, and Professional Development

65 South Front Street, Room 1005

Columbus, Ohio 43266-0308

$k 1$

Enclosures

Please notify me when the 1991-1992 Ohio Educational Directory is available.

Name

Address 
4856 Pioneer Road

Berrien Springs MI 49103

January 25, 1993

Dr. Joseph A. Shurn, Superintendent

Benton Harbor Area Schools

711 East Britain Ave.

Benton Harbor MI 49022

RE: Permission from the Benton Harbor Area School District and Benton Harbor Education Board of Trustees to administer a questionnaire to the district's elementary schools

Dear Dr. Shurn,

As the last stage of my Ph.D. program at Andrews University in Educational Administration and Supervision, my dissertation proposal has been recently approved (copy enclosed).

Consequently I humbly request that you, with the approval of the Benton Harbor Education Board of Trustees, accord me the permission to administer a questionnaire to the district's elementary schools. The results of this questionnaire will confirm or refute the viability of development and administration of a modified academic academy-type program for all the elementary schools of the city of Benton Harbor.

Thank you in advance for this expected courtesy.

Yours truty.

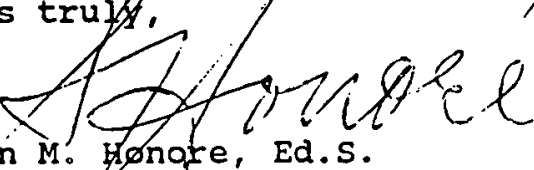

simon M. Honofe, Ed.S.

SMH/jfC

cc: Mrs. Jane strand, President 1992-93 Board of Education 


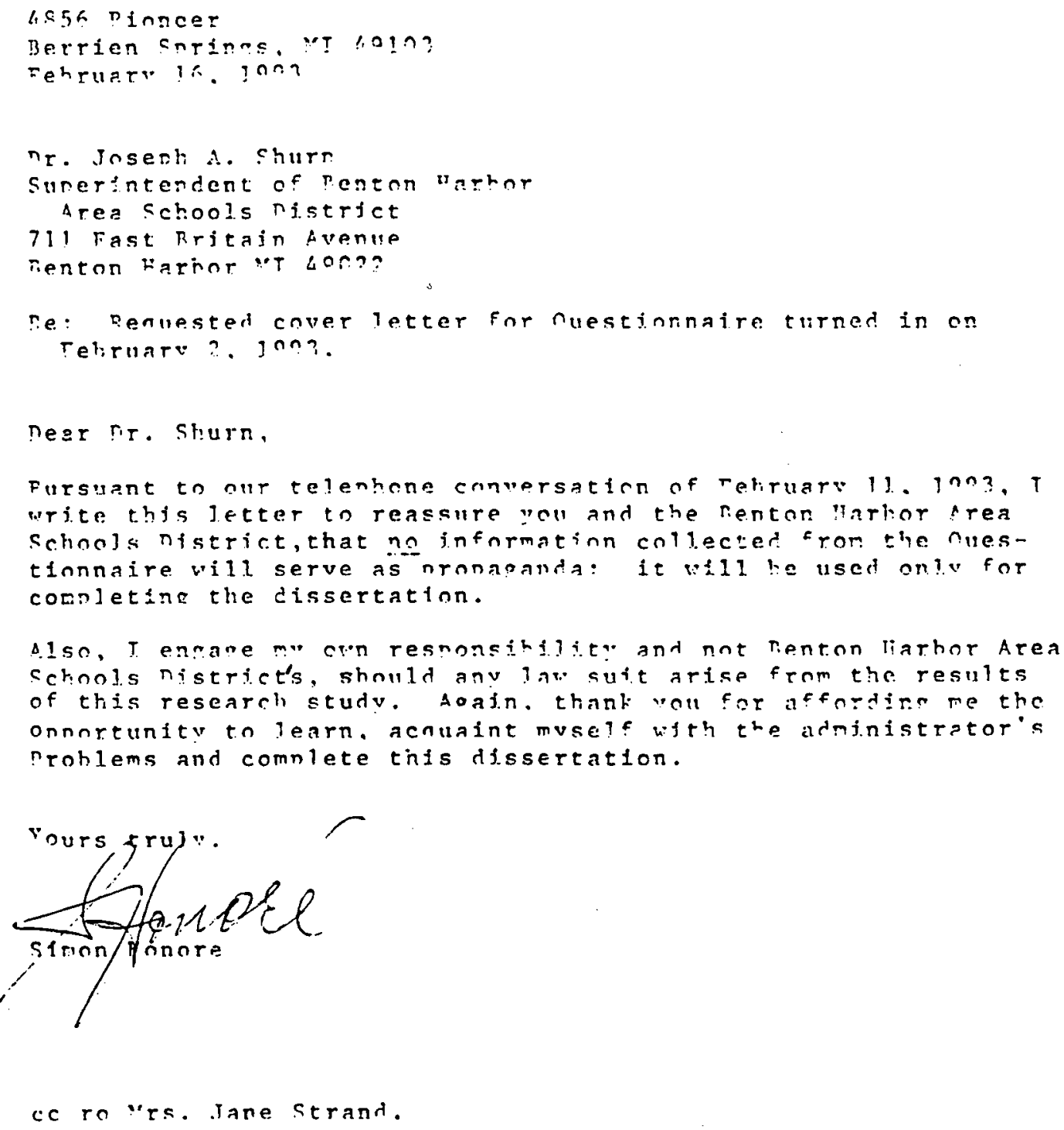




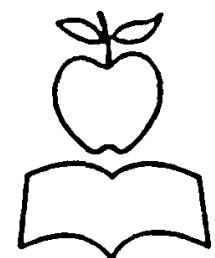

\section{Benton Harbor Area Schools}

March 1, 1993

Mr. Simon Honore

4856 Pioneer

Berrien Springs, MI 49103

Dear Mr. Honore:

This letter is in reference to your letter to Dr. Shurn dated February 16, 1993 regarding the completion of an administrative questionnaire by the Benton Harbor Area schools.

Please be advised that the following procedure has been established for these requests:

1. Submit a letter from the appropriate degree granting academic institution stating the status of the applicant as a graduate student and a candidate for a degree.

2. Submit an official proposal from the same institution regarding the research to be conducted.

3. Submit a letter including the specifics of the Benton Harbor Area Schools involvement in the administration of such research study and/or instruments.

4. Arrange for a meeting with the Assistant Superintendent for Personnel \& Evaluation to discuss the specifics of the research and the involvement of the Benton Harbor Area Schools in it.

Please contact the Personnel office if you have any further questions.

sincerely,

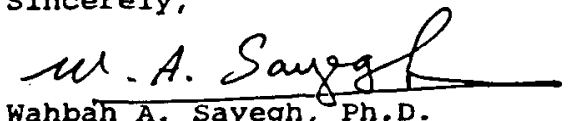

wahbah A. Sayegh, Ph.D.

Assistant Superintendent

for Personnel \& Evaluation

$\operatorname{lm}$

cc: Dr. Shurn

AN EQUAL OPPORTUNITY/AFFIAMATIVE ACTION EMPLOYER LEARN = BLOSSOM = GROW 
March 29, 1993

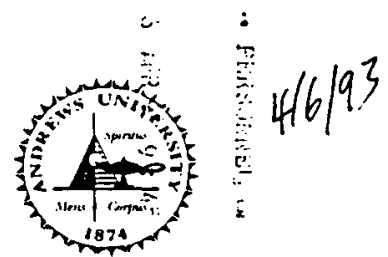

\section{ANDREWS \\ ENIV'RRSITY}

Dr. Wahbah' A. Sayegh

Asst. Supdt for Personnel \& Evaluation

711 E Britain Ave

Benton Harbor, MI 49022

Dear Dr. Sayegh:

This is to certify that Mr. Simon Honore is a doctoral student at Andrews University working toward a Ph.D. degree in the field of Educational Administration.

For your review I am enclosing a copy of his research proposal. He will be conducting the research in Benton Harbor School System pending granting permission from your office.

Benton Harbor Area Schools will be involved in this research study in the following manner:

1. by granting permission for the questionnaire to be seen by teachers and administrators.

2. by giving the candidate a letter of introduction to the schools' principals.

3. by encouraging the principals to support the candidate's efforts.

We shall be delighted to meet with you to discuss the specifics of research and the involvement of Benton Harbor Area Schools. Please suggest a time and date.

We appreciate professional cooperation Andrews University enjoyed over the years with your school system. We look forward to continued cooperation in the tenure of Simon Honore's suिdy

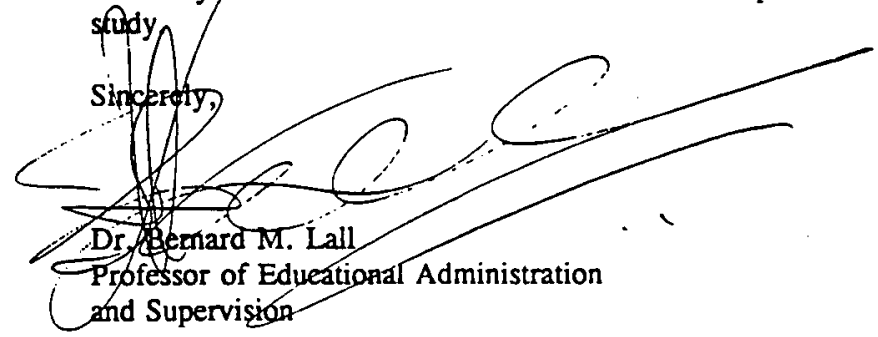

pc

Enclosure 


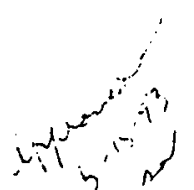

Administrative Center

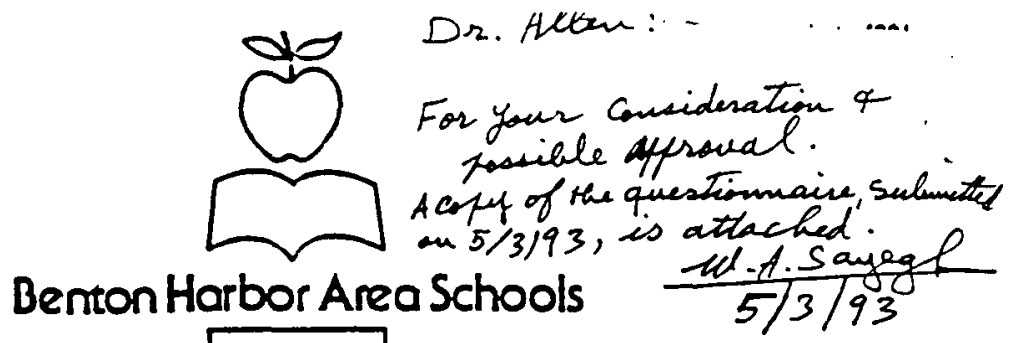

711 E. Brttain Avonue

Benton Harbor, Michigan 49022-1107

(616) $927-0600$

April 28, 1993

Mr. Simon Honore

4856 Pioneer Road

Berrien Springs, MI 49103

Dear Mr. Honore:

We are in receipt of your dissertation proposal and the

letter of March 29, 1993 regarding the administration of a questionnaire to the Benton Harbor Area Schools staff.

Although this proposal briefly discusses the instrument to be used in this study, it does not include a copy of the actial questionnaire to be administered.

Unless we have an opportunity to examine the actual questionnaire that will be used, we cannot give authorization to administer it and abide by the conditions set forth in your letter:

"Ber:=on Harbor Area schools will be involved in this reseazeh study in the followirig manner:

1. by granting permission for the questionnaire to be seen by teachers and administrators.

2. by giving the candidate a letter of introduction

to the schools' principals.

3. by encouraging the principals to support the candidate's efforts."

Again, without the actual questionnaire for review, authorization to administer it cannot be given.

Sincerely,

w. A. Sayey

wahbah A. Sayegh, Ph.D.

Assistant Superintendent

for Personnel \& Evaluation

Im 
196

Spril 30, 1993

Dh. Whabah A. tayegh, Ah. D. Astistant tuperint ten dent for Servonnel and forallention Ae: Questionnaike for becreco psovided. sear DR. Suifegh.

Thank ypu for upeculletter $28,1993 \%$

incloped, fleati find the isuettionnaise itacet th. I digh aleady

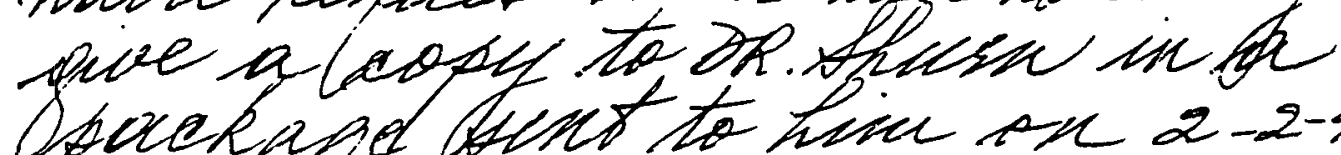
opuekand teret to hine on 2-2-93. As you requested ouly the frespal infyour silettes duffed Twatak?. 19,B, I thougti you alsea dy had it. in an Horktf for all these

yourer trally, ftonosé 
197

Hseil 30, 1993

w. sausest

$5 \mid 3193$

DR. Wakbuh A. Hayegh, Ah. D.

Astibtant Huperiptencient

for Servonnel and foralceation

Re: Guestivenaive forrecreco provided.

Seas DR Sayegh,

Thane ypic for upecertetter

28, 1993\%

of Apsil

inclosed, flears, find the nuectionnaise ilquetted. I digh alieady

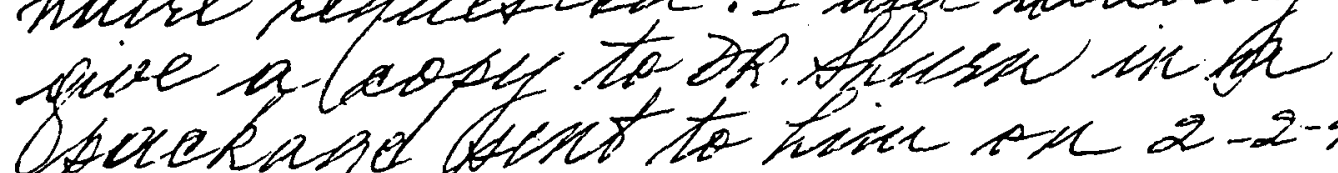
opueknige Gent to tine sh 2-2-93.

At you repuested ouly the Gespai infyourflettes duted thalah!

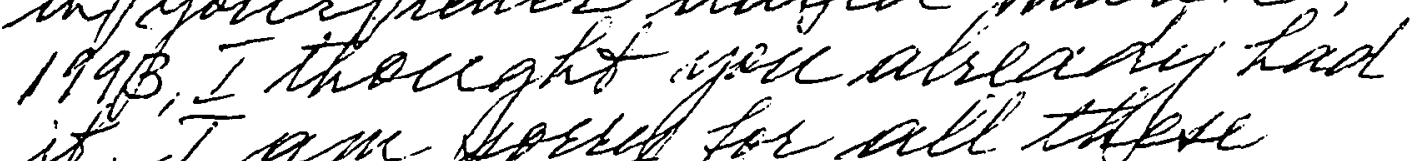
it. I nu- Sostef for all there inconvericenterte.

youer trecly,

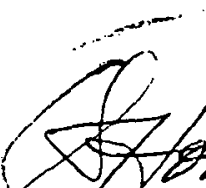


TO: $\quad$ All Staff

FROM: Mrs. Renee' R. Williams, Principal Academic Academy

DATE: $\quad$ May 251993

SUBJECT: COLLEAGUE DISSERTATION RESEARCH

Mr. Simon Honore, a high school science teacher, is completing his doctoral degree work and needs your cooperation to gather research for his dissertation.

He is requesting that you fill out the attached teacher questionnaire sheet and send the parent questionnaire home with one African-American student whose parent would most probably complete the questionnaire and return it.

This is strictly voluntary but Mr. Honore would appreciate your cooperation.

Attachments 


\section{Memorandum}

May 25, 1993

TO:

Morton School Professional staff

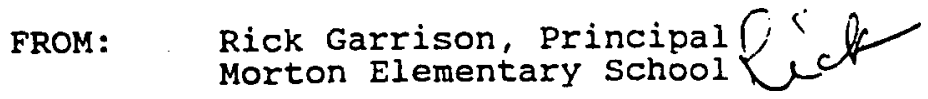

SUBJECT: COLLEAGUE DISSERTATION RESEARCH

Mr. Simon Honore, a high school science teacher, is completing his doctoral degree work and needs your cooperation to gather research for his dissertation.

He is requesting that you fill out the attached teacher questionnaire sheet and send the parent questionnaire home with one African-American student whose parent would most probably complete the questionnaire and return it.

This is strictly voluntary but Mr. Honore would appreciate your cooperation.

Attachments 


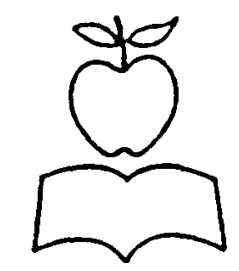

\section{Benton Harbor Area Schools}

To: All Teachers

From: Gregory L. Mauchmar, Princhesl Martindale Elementary schol

Subj: Dissertation Research - Mr. Simon Honore

Date: May 25, 1993

Mr. Simon Honore, a high school science teacher, is completing his doctoral degree work and needs our assistance. Mr. Honoré needs to gather data for his dissertation from the questionnaires attached.

He is requesting that you fill out the teacher questionnaire sheet and send one parent questionnaire home with a reliable student whose parent would most likely complete and return it.

This is strictly voluntary but Mr. Honoré would appreciate your cooperation in this matter. Please return the completed questionnaires to my office no later than Friday, May 28, 1993.

Thank you. 


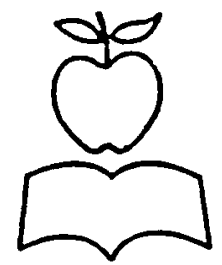

\section{Benton Harbor Area Schools}

Caivin Britain Elementary School $\quad 209$ E. Britain Avenue Benton Harbor, Michigan $\quad$ (616) 927-0633

TO:

FROM :

Calvin Britain staff

RE:

Larry Gavin, for

DATE:

Colleague Dissertation Research

May 26, 1993

Mr. Simon Honore, a high school science teacher, is completing his doctoral degree work and needs our cooperation to gather research for his dissertation.

He is requesting that you fill out the attached teacher questionnaire sheet and send the parent questionnaire home with one African-American student whose parent would most probably complete the questionnaire and return it.

This is strictly voluntary but Mr. Honore would appreciate your cooperation. 
SORTER ELEMENTARY SCHOOL

1421 PIPESTONE ROAD

BENTON HARBOR, MI. 49022

(616) 927-0716

Memorandum

June 14,1993

TO: Sorter School Professional staff

From: $\left.\begin{array}{l}\text { Ann Kennedy, Principal } \\ \text { Sorter Elementary school }\end{array}\right\}$

SUBJECT: COLLEAGUE DISSERTATION RESEARCH

Mr. Simon Honore, a high school science teacher, is completing his doctoral degree work and needs your cooperation to gather research for his dissertation.

He is requesting that you fill out the attached teacher questionnaire sheet and send the parent questionnaire home with one African-American student whose parent would most probable complete the questionnaire and return it.

This is strictly voluntary but Mr. Honore would appreciate your cooperation. 


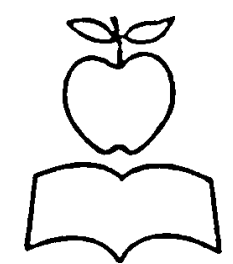

\section{Benton Harbor Area Schools}

June 15,1993

Mr. Simon Honore'

4856 Pioneer Rd.

Berrien Springs, Michigan

Dear Mr. Honore;

Your request concerning the questionnaires was shared with the teachers at our Staff Meeting on May 26th and the materials distributed.

Best wishes as you work on the completion of your dessertation.

Sincerely,

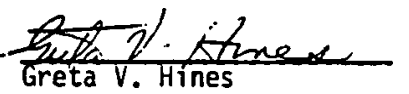

Principal, Northeast School 
APPENDIX C

DATA AND ANALYSIS OF DATA 
001630723241521001101126052001000302031602150707030700070012050408050306101615110508100305081102060812 002610530000520000102224002400000301001700001502051502180503050000000420000007130106041001002003150500 003620340001030100003223041900000505070100051404021100120712060000010514002308150003081213040006030911 004630830040031000003426052001000302031602150707030700070012050408050306140715110508030512010304100500 005620840040031000003427200700000700080900002512000908101225220000000713000010100109050606170000120312 006631330060030100003431121801000405101002121001150200050407050000002560000000000000000000000000000000 007620620200020001002124022200000005001702131100010300091414080000000006000001230000061010150000050608 008631030200030001003227042001010705100500170502150100020101020308110302101718090605100605061006141003 009610530200010001003229032202020705120500180201070101020201010103051505062310190503022505030224130806 010620830040030001001226002501000302031602150608030801050111050309050207121414120509090305091103070813 011620430100020001002224111102001210030101111210091202060708020106080900160715061902121110041010141516 012620920040020001003226052001000302031602150707030700070012050408050306140715110508030512010304100500 013630723241521001101100000000000000000000000000000000000000000000000000000000000000000000000000000000 014620330040031000003200000000000000000000000000000000000000000000000000000000000000000000000000000000 015621030200021000004200000000000000000000000000000000000000000000000000000000000000000000000000000000 016631440040021000004400000000000000000000000000000000000000000000000000000000000000000000000000000000 017620831245321011112225022101010211080204080300070201010201000102081004101510150902070708030806090412 018630841324531011111227042002011208100301080301020301020103010405080507151014111210020312100203010000 019620341245331011113325012201010704101104120500020300030202010103060910091610151109030510080910020300 020620431234521011112428032302001004050504140201020200020103010802040806111610170910110309101103020500 021610115412331011112326022301000807071209030400120401010201000103070807101609170802031009030703080403 022620355412331011113224012101010311020305110301020100030101010103100505101410140802101008030909041010 023520930001020100003424051900001401000601012316031812151321180004061004140420050504010813000003080503 024531230040020001003229131600000901031104000006000004101018060002000115110302240003000805040203001513 025531240001030001003432171104001012010407000100140100010208010208120006091420120410120608110805000013 026531343000030100114224032100001005070700001302000002061224000000000406000003210000022402020024020418 027510330040020010012424042000001004050600061108000000121119130000000006191416070002031311101300010201 028520630040030100113326032002010905050700030200190100010001000104051006121413130404081004040810150308 029521030040030101113230003000000810020306090201090800010002010002060810121811191008020112100802091011 030530820200021000112200000000000000000000000000000000000000000000000000000000000000000000000000000000 031510333000021001113200000000000000000000000000000000000000000000000000000000000000000000000000000000 032520830201521100113100000000000000000000000000000000000000000000000000000000000000000000000000000000 033531630001031010113300000000000000000000000000000000000000000000000000000000000000000000000000000000 034520640214531100111400000000000000000000000000000000000000000000000000000000000000000000000000000000 035530533241531010112200000000000000000000000000000000000000000000000000000000000000000000000000000000 036520930040031001112400000000000000000000000000000000000000000000000000000000000000000000000000000000 037510533241531101113400000000000000000000000000000000000000000000000000000000000000000000000000000000 038520610200010001011100000000000000000000000000000000000000000000000000000000000000000000000000000000 039510330200021101112300000000000000000000000000000000000000000000000000000000000000000000000000000000 040520120040031101112200000000000000000000000000000000000000000000000000000000000000000000000000000000 041510423241521001112200000000000000000000000000000000000000000000000000000000000000000000000000000000 042430340200031001113424042000001000020502000900021002141112100000010404010008080302030208040203070400 043430330040031001013222012100001008070203141001010200020101020003060705101210120802070309030604010200 046421030040030001001213011101000301020700050100030100000100000100010308030403100001030901020208050404 0454209412435210111111418051300000501020800120402120402000010000002030402000306120805020503031200050200 046420832135431011112222111100000401031400140200060000000000000002040510190303190003170300031703041800 047431542314531011114426091700000401101100051706011002180818160003020713060113130002041802061008002200 048410530040030000103406010400010000030300010200030000000000000000020103010003030201010200010203010302 049410440040030010004123002201001001011000130100120000010000010303050804061713100805050508050505100805 050420530040030010003217011600000402020900000900000400090408000000000006080505120300020612040001000800 051420540200030001003422041800000900010700050900010802090412150000050809091220020503040507050201090800 052410520000510001002116002002000000000000000000000000000000000000000000000000000000000000000000000000 053410330040020010003225041901011002080500130200150100010102010003061006131210150905030809050308150604 


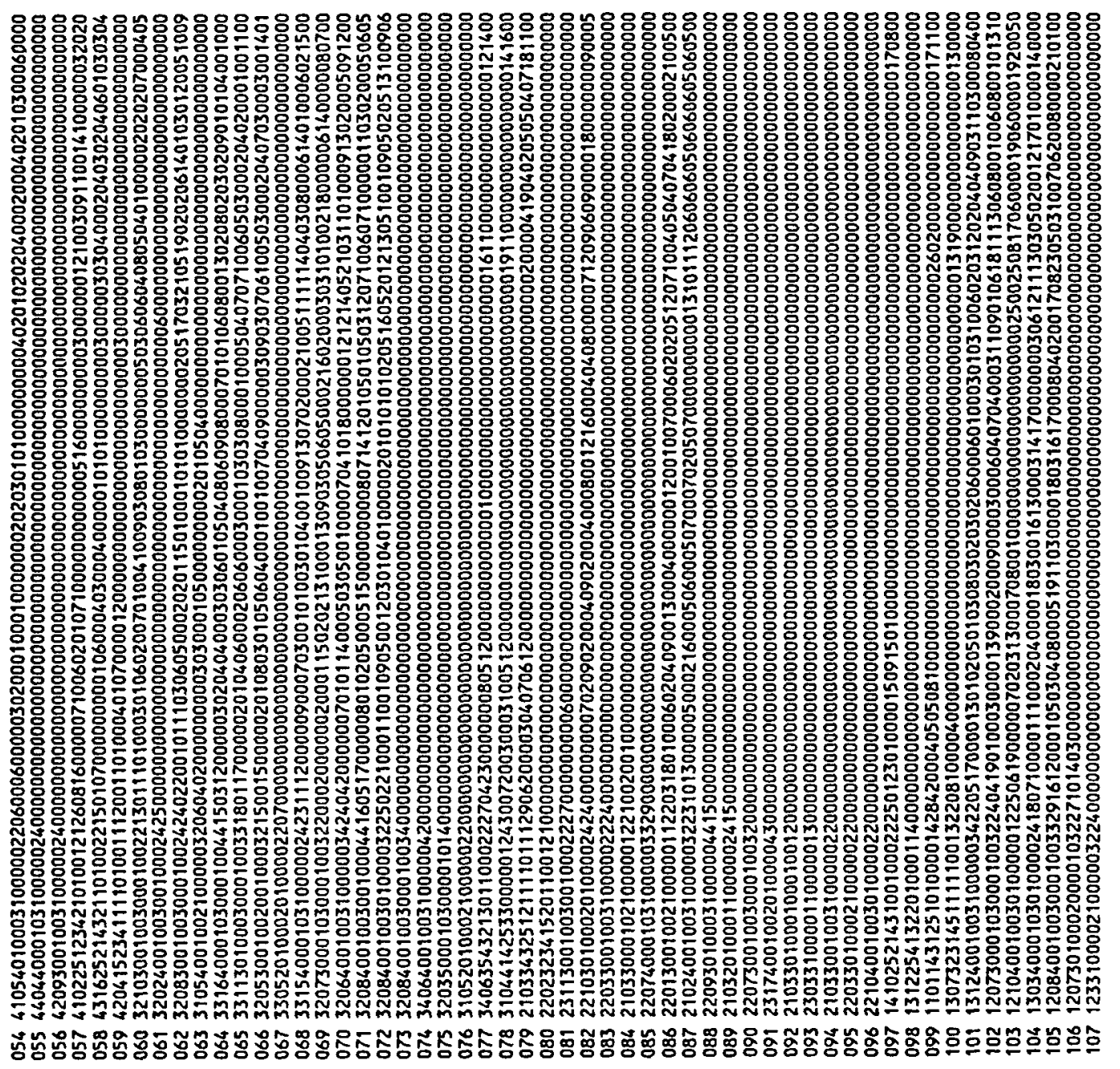


108120930001000100042240320010010050801001503010900000010102010203050410101413111002050910020509090906 109130530010031000003321012000001900000002150600030300120412110002000712150821000904040415030300180000 110110530100020001002400000000000000000000000000000000000000000000000000000000000000000000000000000000 111120620100011000002300000000000000000000000000000000000000000000000000000000000000000000000000000000 112120740001030100000340000000000000000000000000000000000000000000000000000000000000000000000000000000 113120840100021000003200000000000000000000000000000000000000000000000000000000000000000000000000000000 11412093010002010000230000000000000000000000000000000000000000000000000000000000000000000000000000000 115020630100030001004250000000000905002907150600200500000100000000000306000010400610003510050530350500 116010530100030100005443202100022201051001003003000000000000000000000300000000000000000000000000370000 117010330100040010004425081700001003070401140100120000010302010001060810071812130504061005040610070810 1180203400100300100042270620010000000000000000000000000000000000000000000000000000000000000000000000000 119030540010020100004322031900000803060201150401110200000001010202040707121010120505040805050408090508 120020840001030100004429000000000000000000000000000000000000000000000000000000000000000000000000000000 121020940001030100044490445000004000340020000000000000000000000000000060000000000000000000031000000000 122020830010030010004200000000000000000000000000000000000000000000000000000000000000000000000000000000 123020830010020010003200000000000000000000000000000000000000000000000000000000000000000000000000000000 124010530100010100004200000000000000000000000000000000000000000000000000000000000000000000000000000000 125031540010030100004400000000000000000000000000000000000000000000000000000000000000000000000000000000 126020840001030100004400000000000000000000000000000000000000000000000000000000000000000000000000000000

127031330010030100004200000000000000000000000000000000000000000000000000000000000000000000000000000000 128010530010030100004200000000000000000000000000000000000000000000000000000000000000000000000000000000 129020940100031000005400000000000000000000000000000000000000000000000000000000000000000000000000000000 130020630010030001004300000000000000000000000000000000000000000000000000000000000000000000000000000000 131020530010030001004200000000000000000000000000000000000000000000000000000000000000000000000000000000 13202074000103010000440000000000000000000000000000000000000000000000000000000000000000000000000000000 133010340010030001003200000000000000000000000000000000000000000000000000000000000000000000000000000000 134020830100020001004300000000000000000000000000000000000000000000000000000000000000000000000000000000 iss 010430010020010003200000000000000000000000000000000000000000000000000000000000000000000000000000000 136020830010020010003400000000000000000000000000000000000000000000000000000000000000000000000000000000 137031140010030001004400000000000000000000000000000000000000000000000000000000000000000000000000000000 138030540101030001002400000000000000000000000000000000000000000000000000000000000000000000000000000000 139020340010040010004300000000000000000000000000000000000000000000000000000000000000000000000000000000 140030630010030010005400000000000000000000000000000000000000000000000000000000000000000000000000000000 141020540010020100004200000000000000000000000000000000000000000000000000000000000000000000000000000000 142420740001030001001400000000000000000000000000000000000000000000000000000000000000000000000000000000

1433249

1442134

1454111

1462119 
1473111
1482211

1482211

1490000

1502111

1512111

1522111

1530021

1542111

1553131

1562113

1573132

1582132

1593111

1603133

1611133

1622111

1632111

1642111

1652131

1663113

1673111

1682111

1691131

1702211

1712411

1722141

1732111

1742111

1752111

1762111

1774011

1783131

1792131

1801133

1813132

1823131

1832121

1842131

1853131

1863131

1873131

1883131

1893131

1902111

1912133

1923131

1932131

1943111

1953131

1962131

1972133

1981511

1993112

2002131 
2013131

2043111

2032112

2042112

2053132

2063131

2073131

2082131

2093132

2103411

2113131

2123131

2131131

2144211

2151131

2163111

2173531

2183134

2193111

2202111

2211111

2222111

2233132

2243431

2253111

2261331

2272221

2282131

2292111

2302111

2311300

2322111

2331111

2342111

2352142

2362211

2372111

2382111

2393111

2402111

2411410

2422111

2431340

2442111

2452111

2461111

2474213

2482111

2491111

2502111

2514133

2522111

2532111

2542211 


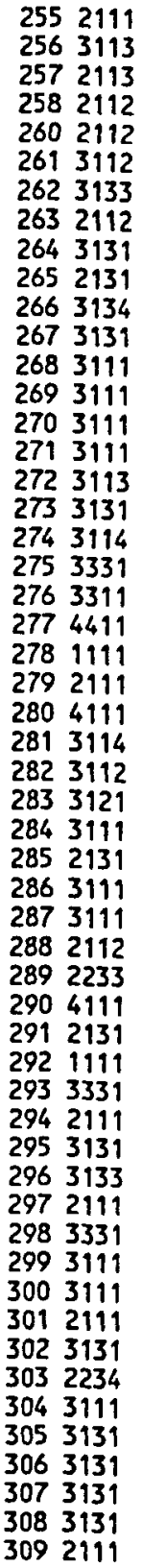


3103131

3113111

3123111

3133111

3143111

3153131

3163131

3173131

3182131

3191111

3203111

32191111

3224114

3234121

3243131

325213

3266121

3273111

3282131

3292111

3302431

3312111

3322132

3332111

3344111

3352111

3362111

3372243

3382111

3392111

3402111

3413111

3423411

3433113

3442131

3453111

3463131

3473430

3483134

3493131

3503131

3513113

3522131

3533331

3543131

3553131

3563111

3572131

3583114

3592112

3602133

3613111

3623131

3633131 
3643131

3652123

3663133

3673133

3683133

3693111

3702111

3713111

3723111

3733111

3743111

3752111

3762131

3773131

3783132

3793121

$380 \quad 2131$

3813221

3821111

3833131

3843131

3852111

3862131

3872133

3881301

3890000

3903131

3912131

3923111

3932131

3942111

3954331

3963112

3972111

3983121

3993111

4002131

4012113

4023112

4034223

4043212

4053121

4062111

4052131

4062112

4073121

4083221

4092111

4102131

4113122

4122113

4132111

4143122

4153122 
$\begin{array}{ll}416 & 4132 \\ 415 & 3131 \\ 416 & 3131 \\ 417 & 2111 \\ 418 & 3111 \\ 419 & 3121 \\ 420 & 3124 \\ 421 & 3142 \\ 423 & 3141 \\ 425 & 3111 \\ 426 & 2111 \\ 427 & 3131 \\ 429 & 2193 \\ 430 & 2111 \\ 431 & 2113 \\ 432 & 1111 \\ 433 & 3221 \\ 434 & 0000 \\ 435 & 2113 \\ 436 & 2111 \\ 437 & 3131 \\ 438 & 2112 \\ 439 & 3111 \\ 440 & 3131 \\ 441 & 2111 \\ 442 & 3231 \\ 443 & 3121 \\ 444 & 2143 \\ 445 & 3151 \\ 446 & 2111 \\ 447 & 3121 \\ 448 & 2131 \\ 449 & 3111 \\ 450 & 3131 \\ 451 & 3111 \\ 452 & 1112 \\ 453 & 3141 \\ 454 & 2111 \\ 455 & 3214 \\ 456 & 2151 \\ 457 & 2041 \\ 458 & 2114 \\ 459 & 2331 \\ 460 & 1311 \\ 461 & 3111 \\ 462 & 2131 \\ 463 & 21111 \\ 464 & 2133 \\ 465 & 3121 \\ 466 & 3112 \\ 467 & 2131 \\ 468 & 3122 \\ 469 & 3122 \\ 470 & 2113\end{array}$ 


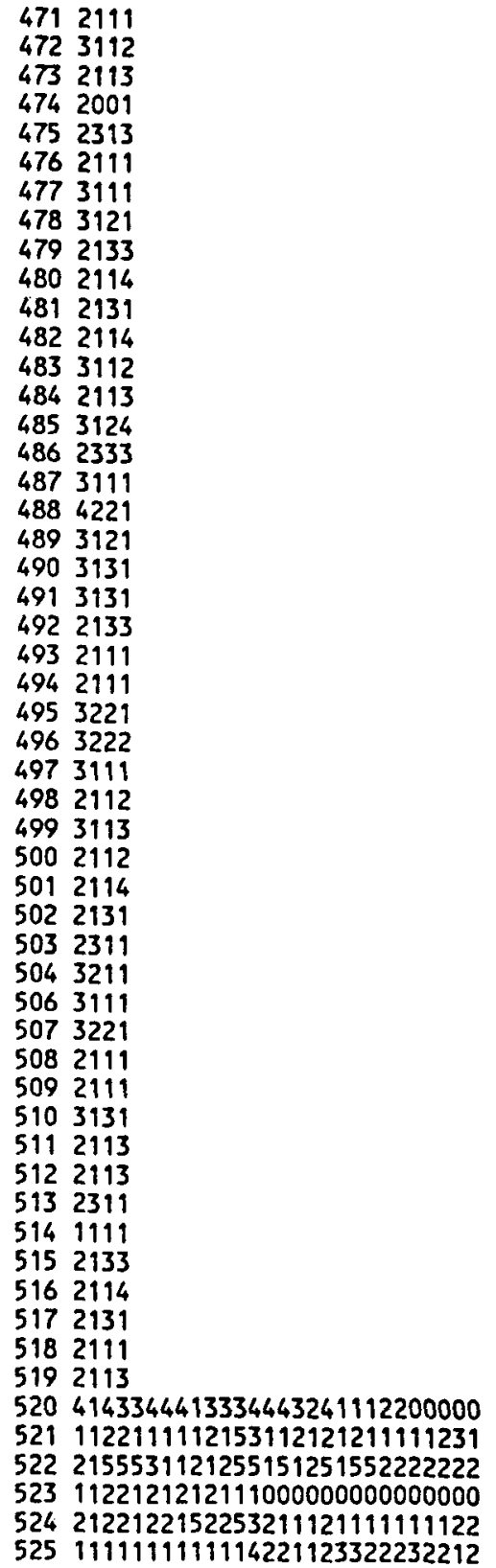


5262112221111112111212122221222

5272111112111113222221221111122

5282221132112222212231112211111

5292222222122212021122222222222

53021111121522525111111111111111 
get file='data.sys'.

The SPSS/PC+ system file is read from

file data.sys

The file was created on 7/15/93 at 14:57:49

and is titled SPSS/PC+

The SPSS/PC+ system file contains

529 cases, each consisting of

94 variables (including system variables).

94 variables will be used in this session.

Page 3

SPSS/PC+

$7 / 16 / 93$

This procedure was completed at 12:53:20

missing value ID TO T6 T8 TS PI TO A28(O).

fre all.

**** Memory allows a total of 32767 Values, accumulated across all Variables. There also may be up to 4096 Value Labels for each Variable. 
T1

Value Label

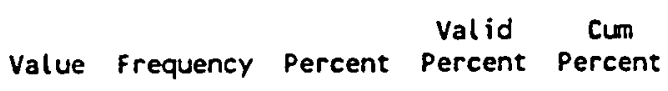

$\begin{array}{rrrrrr}1 & 18 & 3.4 & 15.7 & 15.7 \\ 2 & 18 & 3.4 & 15.7 & 31.3 \\ 3 & 19 & 3.6 & 16.5 & 47.8 \\ 4 & 19 & 3.6 & 16.5 & 64.3 \\ 5 & 19 & 3.6 & 16.5 & 80.9 \\ 6 & 22 & 4.2 & 19.1 & 100.0 \\ 0 & 387 & 73.2 & \text { Missing } & \\ 0 & 27 & 5.1 & \text { Missing } & \\ & \ldots \ldots & \ldots . . . & \ldots \ldots & \ldots . . . & \end{array}$

Valid cases $\quad 115 \quad$ Missing cases $\quad 414$

12

Value Label

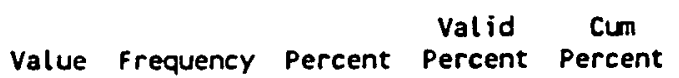

$\begin{array}{rrrrr}1 & 31 & 5.9 & 21.8 & 21.8 \\ 2 & 72 & 13.6 & 50.7 & 72.5 \\ 3 & 35 & 6.6 & 24.6 & 97.2 \\ 4 & 4 & .8 & 2.8 & 100.0 \\ . & 387 & 73.2 & \text { Missing } & \\ \text { Total } & 529 & 100.0 & 100.0 & \end{array}$

Valid cases $\quad 142 \quad$ Missing cases 387

13

Value Label

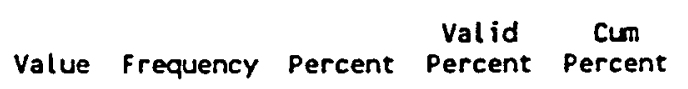

$\begin{array}{rrrrr}1 & 4 & .8 & 2.8 & 2.8 \\ 2 & 4 & .8 & 2.8 & 5.6 \\ 3 & 24 & 4.5 & 16.9 & 22.5 \\ 4 & 8 & 1.5 & 5.6 & 28.2 \\ 5 & 22 & 4.2 & 15.5 & 43.7 \\ 6 & 11 & 2.1 & 7.7 & 51.4 \\ 7 & 11 & 2.1 & 7.7 & 59.2 \\ 8 & 20 & 3.8 & 14.1 & 73.2 \\ 9 & 10 & 1.9 & 7.0 & 80.3 \\ 10 & 9 & 1.7 & 6.3 & 86.6 \\ 11 & 3 & .6 & 2.1 & 88.7 \\ 12 & 4 & .8 & 2.8 & 91.5 \\ 13 & 3 & .6 & 2.1 & 93.7 \\ 14 & 1 & .2 & .7 & 94.4 \\ 15 & 3 & .6 & 2.1 & 96.5 \\ 16 & 3 & .6 & 2.1 & 98.6 \\ 17 & 1 & .2 & .7 & 99.3 \\ 33 & 1 & .2 & .7 & 100.0 \\ . & 387 & 73.2 & \text { Missing } & \\ \text { Totat } & \ldots \ldots & \ldots . . . & -\ldots . . . & \end{array}$

Valid cases 
14

Value Label

\begin{tabular}{|c|c|c|c|c|}
\hline Value & Frequency & Percent & $\begin{array}{l}\text { Valid } \\
\text { Percent }\end{array}$ & $\begin{array}{l}\text { Cum } \\
\text { Percent }\end{array}$ \\
\hline $\begin{array}{l}1 \\
2 \\
3 \\
4 \\
5\end{array}$ & $\begin{array}{r}5 \\
16 \\
70 \\
49 \\
2 \\
387\end{array}$ & $\begin{array}{r}.9 \\
3.0 \\
13.2 \\
9.3 \\
.4 \\
73.2\end{array}$ & $\begin{array}{r}3.5 \\
11.3 \\
49.3 \\
34.5 \\
1.4 \\
\text { Missing }\end{array}$ & $\begin{array}{r}3.5 \\
14.8 \\
64.1 \\
98.6 \\
100.0\end{array}$ \\
\hline Total & 529 & 100.0 & 100.0 & \\
\hline
\end{tabular}

Valid cases $\quad 142 \quad$ Missing cases 387

T5A

Value Label

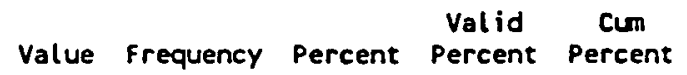

\begin{tabular}{rrrrr}
1 & 7 & 1.3 & 25.0 & 25.0 \\
2 & 4 & .8 & 14.3 & 39.3 \\
3 & 7 & 1.3 & 25.0 & 64.3 \\
4 & 2 & .4 & 7.1 & 79.4 \\
5 & 8 & 1.5 & 28.6 & 100.0 \\
0 & 387 & 73.2 & Missing & \\
Total & 114 & 21.6 & Missing & \\
\hline & 529 & 100.0 & 100.0 &
\end{tabular}

Valid cases $28 \quad$ Missing cases 501

T5B

Value Label

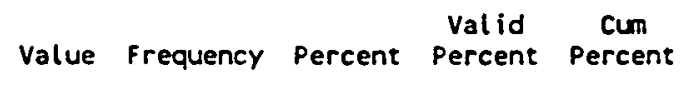

$\begin{array}{rrrrr}1 & 24 & 4.5 & 41.4 & 41.4 \\ 2 & 23 & 4.3 & 39.7 & 81.0 \\ 3 & 6 & 1.1 & 10.3 & 91.4 \\ 4 & 5 & .9 & 8.6 & 100.0 \\ 0 & 387 & 73.2 & \text { Missing } & \\ 0 & 84 & 15.9 & \text { Missing } & \\ & \ldots \ldots . . & \ldots \ldots .- & \ldots \ldots . . & \end{array}$

Valid cases $\quad 58 \quad$ Missing cases 471 
Page 14

TSC

Value Label Vatue Frequency Percent Percent Percent

$\begin{array}{rrrr}1 & 48 & 9.1 & 57.1 \\ 2 & 4 & .8 & 4.8 \\ 3 & 4 & .8 & 4.8 \\ 4 & 28 & 5.3 & 33.3 \\ 0 & 387 & 73.2 & \text { Missing } \\ 0 & 58 & 11.0 & \text { Missing } \\ & \ldots . . . & \ldots . . . & \ldots . . . \\ \text { Total } & 529 & 100.0 & 100.0\end{array}$

Vatid cases

84

Missing cases

445

TSD

Value Label

Value Frequency Percent Percent percent

$\begin{array}{rrrrr}1 & 28 & 5.3 & 58.3 & 58.3 \\ 2 & 4 & .8 & 8.3 & 66.7 \\ 3 & 3 & .6 & 6.3 & 72.9 \\ 4 & 8 & 1.5 & 16.7 & 89.6 \\ 5 & 5 & .9 & 10.4 & 100.0 \\ 0 & 387 & 73.2 & \text { Missing } & \\ 0 & 94 & 17.8 & \text { Missing } & \\ \text { Total } & \ldots \ldots & \ldots \ldots . . & \ldots \ldots . . & \end{array}$

Valid cases

Missing cases

481

T5E

Value Label

$$
\text { Value Frequency Percent Percent Percent }
$$

$\begin{array}{rrrrr}1 & 3 & .6 & 10.0 & 10.0 \\ 2 & 2 & .4 & 6.7 & 16.7 \\ 3 & 7 & 1.3 & 23.3 & 40.0 \\ 4 & 2 & .4 & 6.7 & 46.7 \\ 5 & 16 & 3.0 & 53.3 & 100.0 \\ 0 & 387 & 73.2 & \text { Missing } & \\ \text { Total } & 112 & 21.2 & \text { Missing } & \end{array}$

Valid cases $\quad 30 \quad$ Missing cases 499 
T6

Value Label

$\begin{array}{rrrrr}\text { Value Frequency } & \text { Percent } & \begin{array}{c}\text { Valid } \\ \text { Percent }\end{array} & \begin{array}{c}\text { Cum } \\ \text { Percent }\end{array} \\ 1 & 13 & 2.5 & 9.2 & 9.2 \\ 2 & 44 & 8.3 & 31.2 & 40.4 \\ 3 & 82 & 15.5 & 58.2 & 98.6 \\ 4 & 2 & .4 & 1.4 & 100.0 \\ \text { 0 } & 387 & 73.2 & \text { Missing } & \\ \text { rotal } & 1 & .2 & \text { Missing } & \\ & 529 & 100.0 & 100.0 & \end{array}$

Valid cases $\quad 149 \quad$ Missing cases $\quad 388$

T7A

Value Label

$7 B$

Value Label

I7C

Value Label

$$
\begin{array}{rrrrr}
\text { Value } & \text { Frequency } & \text { Percent } & \text { Percent } & \text { Percent } \\
& & & & \\
0 & 109 & 20.6 & 76.8 & 76.8 \\
1 & 33 & 6.2 & 23.2 & 100.0 \\
. & 387 & 73.2 & \text { Missing } & \\
\text { Total } & 529 & 100.0 & 100.0 &
\end{array}
$$

Valid cases $\quad 142 \quad$ Missing cases $\quad 387$
Valid Cum Value Frequency Percent Percent Percent

$\begin{array}{rrrrr}0 & 85 & 16.1 & 59.9 & 59.9 \\ 1 & 57 & 10.8 & 40.1 & 100.0 \\ 1 & 387 & 73.2 & \text { Missing } & \\ & \ldots \ldots & -\ldots . . . & \ldots \ldots . . & \end{array}$

Missing cases 387 
i70

Value Label

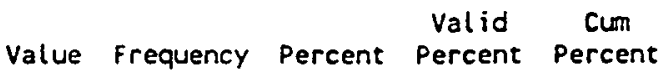

$\begin{array}{crrrr}0 & 87 & 16.4 & 61.3 & 61.3 \\ 1 & 55 & 10.4 & 38.7 & 100.0 \\ . & 387 & 73.2 & \text { Missing } & \\ & \ldots & \ldots & \\ \text { Total } & 529 & 100.0 & 100.0\end{array}$

Valid cases $\quad 142 \quad$ Missing cases $\quad 387$

T7E

Value Label

Value Frequency Percent Percent Percent

$\begin{array}{rrrrr}0 & 112 & 21.2 & 78.9 & 78.9 \\ 1 & 30 & 5.7 & 21.1 & 100.0 \\ \cdot & 387 & 73.2 & \text { Missing } & \\ \text { Total } & 529 & 100.0 & 100.0 & \end{array}$

Valid cases $\quad 142 \quad$ Missing cases $\quad 387$

T7F

Value Label

\begin{tabular}{rrrrr} 
Value & Frequency & Percent & $\begin{array}{c}\text { Valid } \\
\text { Percent }\end{array}$ & $\begin{array}{c}\text { Cum } \\
\text { Percent }\end{array}$ \\
0 & 107 & 20.2 & 75.4 & 75.4 \\
1 & 32 & 6.0 & 22.5 & 97.9 \\
3 & 1 & .2 & .7 & 98.6 \\
4 & 2 & .4 & 1.4 & 100.0 \\
. & 387 & 73.2 & Missing & \\
Total & $-\ldots . .-$ & \multicolumn{1}{c}{..... } & $\ldots . . .-$ &
\end{tabular}

Valid cases $142 \quad$ Missing cases $\quad 387$

18

Value Label

$\begin{array}{rrrrr}\text { Value Frequency } & \text { Percent } & \begin{array}{c}\text { Valid } \\ \text { Percent }\end{array} & \begin{array}{c}\text { Cum } \\ \text { Percent }\end{array} \\ 1 & 19 & 3.6 & 13.6 & 13.6 \\ 2 & 44 & 8.3 & 31.4 & 45.0 \\ 3 & 45 & 8.5 & 32.1 & 77.1 \\ 4 & 29 & 5.5 & 20.7 & 97.9 \\ 5 & 3 & .6 & 2.1 & 100.0 \\ \text { 0 } & 387 & 73.2 & \text { Missing } & \\ & 2 & .4 & \text { Missing } & \\ \text { Total } & \ldots 29 & 100.0 & 100.0 & \end{array}$

Valid cases $\quad 140 \quad$ Missing cases $\quad 389$ 
Value Label

$$
\begin{array}{rrrrr}
\text { Vatue Frequency } & \text { Percent } & \begin{array}{c}
\text { Valid } \\
\text { Percent }
\end{array} & \begin{array}{c}
\text { Cum } \\
\text { Percent }
\end{array} \\
1 & 13 & 2.5 & 9.2 & 9.2 \\
2 & 62 & 19.7 & 43.7 & 52.8 \\
3 & 19 & 3.6 & 13.4 & 66.2 \\
4 & 48 & 9.1 & 33.8 & 100.0 \\
. & 387 & 73.2 & \text { Missing } & \\
& \ldots \ldots & -\ldots . .- & -\ldots . . & \\
\text { Total } & 529 & 100.0 & 100.0 &
\end{array}
$$

Valid cases $\quad 142 \quad$ Missing cases $\quad 387$

T82

Value Label

Value Label

(n)

$\begin{array}{rrrrr}\text { Value } & \text { Frequency } & \text { Percent } & \begin{array}{c}\text { Valid } \\ \text { Percent }\end{array} & \begin{array}{c}\text { Cum } \\ \text { Percent }\end{array} \\ 0 & 56 & 10.6 & 39.4 & 39.4 \\ 6 & 3 & .6 & 2.1 & 41.5 \\ 7 & 1 & .2 & .7 & 42.3 \\ 12 & 1 & .2 & .7 & 43.0 \\ 13 & 2 & .4 & 1.4 & 44.4 \\ 15 & 5 & .9 & 3.5 & 47.9 \\ 16 & 2 & .4 & 1.4 & 49.3 \\ 17 & 1 & .2 & .7 & 50.0 \\ 18 & 3 & .6 & 2.1 & 52.1 \\ 20 & 1 & .2 & .7 & 52.8 \\ 21 & 2 & .4 & 1.4 & 54.2 \\ 22 & 8 & 1.5 & 5.6 & 59.9 \\ 23 & 4 & .8 & 2.8 & 62.7 \\ 24 & 13 & 2.5 & 9.2 & 71.8 \\ 25 & 7 & 1.3 & 4.9 & 76.8 \\ 26 & 8 & 1.5 & 5.6 & 82.4 \\ 27 & 7 & 1.3 & 4.9 & 87.3 \\ 28 & 2 & .4 & 1.4 & 88.7 \\ 29 & 6 & 1.1 & 4.2 & 93.0 \\ 30 & 2 & .4 & 1.4 & 94.4 \\ 31 & 1 & .2 & .7 & 95.1 \\ 32 & 1 & .2 & .7 & 95.8 \\ 40 & 3 & .6 & 2.1 & 97.9 \\ 43 & 1 & .2 & .7 & 98.6 \\ 50 & 1 & .2 & .7 & 99.3 \\ 90 & 1 & .2 & .7 & 100.0 \\ . & 387 & 73.2 & \text { Missing } & \\ \text { Total } & . . .5 & -. . .5 & . . . .5 & \\ & 529 & 100.0 & 100.0 & \end{array}$

Valid cases 
Page 18

T83A

Value Label
SPSS/PC+

$7 / 16 / 93$

\begin{tabular}{|c|c|c|c|c|}
\hline Value & Frequency & Percent & $\begin{array}{l}\text { Valid } \\
\text { Percent }\end{array}$ & $\begin{array}{c}\text { Cum } \\
\text { Percen }\end{array}$ \\
\hline $\begin{array}{r}0 \\
1 \\
2 \\
3 \\
4 \\
5 \\
6 \\
7 \\
8 \\
9 \\
10 \\
11 \\
12 \\
13 \\
16 \\
17 \\
20 \\
32 \\
42 \\
44 \\
50\end{array}$ & $\begin{array}{r}78 \\
11 \\
5 \\
7 \\
11 \\
7 \\
2 \\
2 \\
3 \\
1 \\
2 \\
3 \\
1 \\
1 \\
1 \\
1 \\
2 \\
1 \\
1 \\
1 \\
1\end{array}$ & $\begin{array}{r}14.7 \\
2.1 \\
.9 \\
1.3 \\
2.1 \\
1.3 \\
.4 \\
.4 \\
.6 \\
.2 \\
.4 \\
.6 \\
.2 \\
.2 \\
.2 \\
.2 \\
.4 \\
.2 \\
.2 \\
.2 \\
.2\end{array}$ & $\begin{array}{r}54.9 \\
7.7 \\
3.5 \\
4.9 \\
7.7 \\
4.9 \\
1.4 \\
1.4 \\
2.1 \\
.7 \\
1.4 \\
2.1 \\
.7 \\
.7 \\
.7 \\
.7 \\
1.4 \\
.7 \\
.7 \\
.7 \\
.7\end{array}$ & $\begin{array}{r}54.9 \\
62.7 \\
66.2 \\
71.1 \\
78.9 \\
83.8 \\
85.2 \\
86.6 \\
88.7 \\
89.4 \\
90.8 \\
93.0 \\
93.7 \\
94.4 \\
95.1 \\
95.8 \\
97.2 \\
97.9 \\
98.6 \\
99.3 \\
100.0\end{array}$ \\
\hline${ }^{\circ}$ & 387 & & Missing & \\
\hline otal & 529 & 100.0 & 100.0 & \\
\hline
\end{tabular}


TB38

Value Label

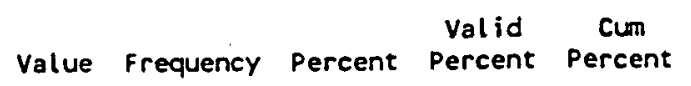

0
2
4
6
7
10
11
12
13
14
15
16
17
18
19
20
21
22
23
24
25
30
50
61

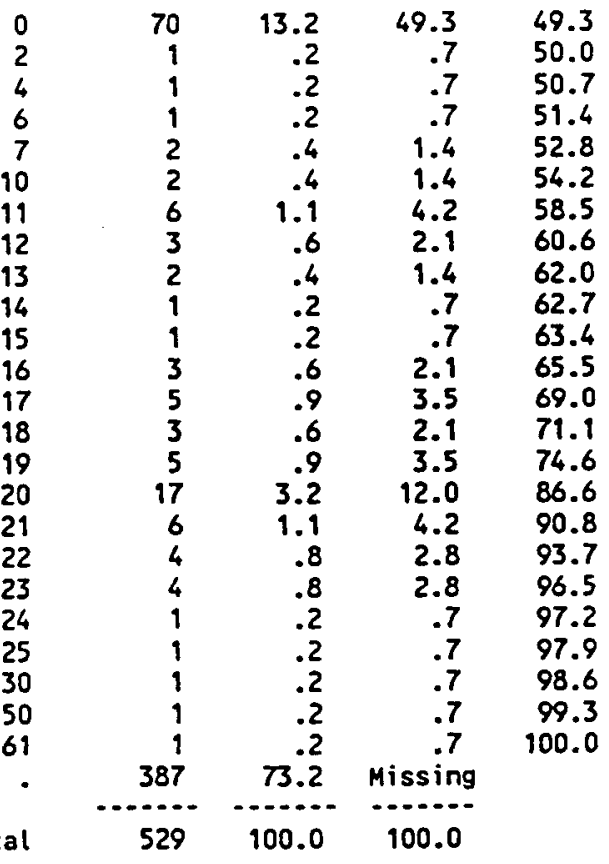

Valid cases

Missing cases

387

T83C

Value Label

Valid cases

$\begin{array}{rrrrr}\text { Value } & \text { Frequency } & \text { Percent } & \begin{array}{c}\text { Valid } \\ \text { Percent }\end{array} & \begin{array}{c}\text { Cum } \\ \text { Percent }\end{array} \\ 0 & 109 & 20.6 & 76.8 & 76.8 \\ 1 & 21 & 4.0 & 14.8 & 91.5 \\ 2 & 6 & 1.1 & 4.2 & 95.8 \\ 3 & 2 & .4 & 1.4 & 97.2 \\ 4 & 2 & .4 & 1.4 & 98.6 \\ 10 & 1 & .2 & .7 & 99.3 \\ 90 & 1 & .2 & .7 & 100.0 \\ . & 387 & 73.2 & \text { Missing } & \\ \text { Total } & \ldots 2 . . & \ldots . . . . & \ldots . . . . & \end{array}$

Missing cases
387 
TB3D

Value Label

$$
\begin{array}{rrrrr}
\text { Value } & \text { Frequency } & \text { Percent } & \begin{array}{c}
\text { Valid } \\
\text { Percent }
\end{array} & \begin{array}{c}
\text { Cum } \\
\text { Percent }
\end{array} \\
0 & 124 & 23.4 & 87.3 & 87.3 \\
1 & 13 & 2.5 & 9.2 & 96.5 \\
2 & 2 & .4 & 1.4 & 97.9 \\
3 & 1 & .2 & .7 & 98.6 \\
4 & 1 & .2 & .7 & 99.3 \\
5 & 1 & .2 & .7 & 100.0 \\
. & 387 & 73.2 & \text { Missing } & \\
\text { Total } & \ldots 29 & 100.0 & 100.0 &
\end{array}
$$

Valid cases $142 \quad$ Missing cases 387

TB4A

Value Label

Value Frequency Percent

Valid Cum

Percent Percent

$\begin{array}{rrrrr}0 & 78 & 14.7 & 54.9 & 54.9 \\ 2 & 4 & .8 & 2.8 & 57.7 \\ 3 & 12 & 2.3 & 8.5 & 66.2 \\ 4 & 6 & 1.1 & 4.2 & 70.4 \\ 5 & 5 & .9 & 3.5 & 73.9 \\ 6 & 2 & .4 & 1.4 & 75.4 \\ 7 & 7 & 1.3 & 4.9 & 80.3 \\ 8 & 4 & .8 & 2.8 & 83.1 \\ 9 & 5 & .9 & 3.5 & 86.6 \\ 10 & 10 & 1.9 & 7.0 & 93.7 \\ 11 & 2 & .4 & 1.4 & 95.1 \\ 12 & 2 & .4 & 1.4 & 96.5 \\ 13 & 1 & .2 & .7 & 97.2 \\ 14 & 1 & .2 & .7 & 97.9 \\ 19 & 1 & .2 & .7 & 98.6 \\ 22 & 1 & .2 & .7 & 99.3 \\ 40 & 1 & .2 & .7 & 100.0 \\ . & 387 & 73.2 & \text { Missing } & \\ \text { Total } & \ldots . . & \ldots . . . & -. . .-. & \end{array}$

Valid cases 
TBLB

Value Label
Value frequency Percent Percent percent

0
1
2
3
4
5
7
8
10
11
12
15
50
70

$\begin{array}{llll}84 & 15.9 & 59.2 & 59.2\end{array}$

$\begin{array}{llll}17 & 3.2 & 12.0 & 71.1\end{array}$

$\begin{array}{llll}10 & 1.9 & 7.0 & 78.2\end{array}$

$\begin{array}{llll}4 & .8 & 2.8 & 81.0\end{array}$

$\begin{array}{llll}3 & .6 & 2.1 & 83.1\end{array}$

$\begin{array}{llll}8 & 1.5 & 5.6 & 88.7\end{array}$

$2 \quad .4 \quad 1.4 \quad 90.1$

$\begin{array}{llll}4 & .8 & 2.8 & 93.0\end{array}$

$\begin{array}{llll}4 & .8 & 2.8 & 95.8\end{array}$

$\begin{array}{llll}2 & .4 & 1.4 & 97.2\end{array}$

$\begin{array}{llll}1 & .2 & .7 & 97.9\end{array}$

$\begin{array}{llll}1 & .2 & .7 & 98.6\end{array}$

$\begin{array}{llll}1 & .2 & .7 & 99.3\end{array}$

$\begin{array}{lllll}1 & .2 & .7 & 100.0\end{array}$

$\begin{array}{rrr}387 & 73.2 & \text { Missing } \\ - & & \end{array}$

$529 \quad 100.0 \quad 100.0$

Valid cases $\quad 142 \quad$ Missing cases $\quad 387$

TB4C

Value Label

$$
\text { Value Frequency Percent Percent percent }
$$

$\begin{array}{rrrrr}0 & 78 & 14.7 & 54.9 & 54.9 \\ 1 & 6 & 1.1 & 4.2 & 59.2 \\ 2 & 10 & 1.9 & 7.0 & 66.2 \\ 3 & 9 & 1.7 & 6.3 & 72.5 \\ 4 & 4 & .8 & 2.8 & 75.4 \\ 5 & 6 & 1.1 & 4.2 & 79.6 \\ 6 & 5 & .9 & 3.5 & 83.1 \\ 7 & 7 & 1.3 & 4.9 & 88.0 \\ 8 & 4 & .8 & 2.8 & 90.8 \\ 9 & 3 & .6 & 2.1 & 93.0 \\ 10 & 6 & 1.1 & 4.2 & 97.2 \\ 12 & 1 & .2 & .7 & 97.9 \\ 20 & 1 & .2 & .7 & 98.6 \\ 34 & 1 & .2 & .7 & 99.3 \\ 80 & 1 & .2 & .7 & 100.0 \\ . & 387 & 73.2 & \text { Missing } & \\ \text { Total } & \ldots . . . & \ldots . . . . & \ldots . . . . & \end{array}$

Valid cases $\quad 142 \quad$ Missing cases $\quad 387$ 
Page 22

SPSS/PC+

$7 / 16 / 93$

TB4D

Value Label

\begin{tabular}{|c|c|c|c|c|}
\hline value & Frequency & Percent & $\begin{array}{l}\text { Valid } \\
\text { Percent }\end{array}$ & $\underset{\text { Percent }}{\text { Cum }}$ \\
\hline $\begin{array}{r}0 \\
1 \\
2 \\
3 \\
4 \\
5 \\
6 \\
7 \\
8 \\
9 \\
10 \\
11 \\
12 \\
13 \\
14 \\
15 \\
16 \\
17 \\
29 \\
31\end{array}$ & $\begin{array}{r}75 \\
3 \\
6 \\
7 \\
4 \\
9 \\
4 \\
4 \\
2 \\
3 \\
4 \\
3 \\
4 \\
1 \\
2 \\
2 \\
5 \\
2 \\
1 \\
1 \\
387\end{array}$ & $\begin{array}{r}14.2 \\
.6 \\
1.1 \\
1.3 \\
.8 \\
1.7 \\
.8 \\
.8 \\
.4 \\
.6 \\
.8 \\
.6 \\
.8 \\
.2 \\
.4 \\
.4 \\
.9 \\
.4 \\
.2 \\
.2 \\
73\end{array}$ & $\begin{array}{r}52.8 \\
2.1 \\
4.2 \\
4.9 \\
2.8 \\
6.3 \\
2.8 \\
2.8 \\
1.4 \\
2.1 \\
2.8 \\
2.1 \\
2.8 \\
.7 \\
1.4 \\
1.4 \\
3.5 \\
1.4 \\
.7 \\
.7 \\
\text { Missing }\end{array}$ & $\begin{array}{r}52.8 \\
54.9 \\
59.2 \\
64.1 \\
66.9 \\
73.2 \\
76.1 \\
78.9 \\
80.3 \\
82.4 \\
85.2 \\
87.3 \\
90.1 \\
90.8 \\
92.3 \\
93.7 \\
97.2 \\
98.6 \\
99.3 \\
100.0\end{array}$ \\
\hline Total & 529 & 100.0 & 100.0 & \\
\hline
\end{tabular}

Valid cases

Missing cases

387

TBGE

Value Label

$\begin{array}{rrrrr}\text { Value } & \text { Frequency } & \text { Percent } & \begin{array}{c}\text { Valid } \\ \text { Percent }\end{array} & \begin{array}{c}\text { Cum } \\ \text { Percent }\end{array} \\ 0 & 109 & 20.6 & 76.8 & 76.8 \\ 1 & 11 & 2.1 & 7.7 & 84.5 \\ 2 & 9 & 1.7 & 6.3 & 90.8 \\ 3 & 1 & .2 & .7 & 91.5 \\ 4 & 4 & .8 & 2.8 & 94.4 \\ 5 & 1 & .2 & .7 & 95.1 \\ 6 & 1 & .2 & .7 & 95.8 \\ 7 & 2 & .4 & 1.4 & 97.2 \\ 9 & 1 & .2 & .7 & 97.9 \\ 20 & 1 & .2 & .7 & 98.6 \\ 30 & 1 & .2 & .7 & 99.3 \\ 90 & 1 & .2 & .7 & 100.0 \\ . & 387 & 73.2 & \text { Missing } & \\ \text { Total } & \ldots . . . & -. . . . . & \ldots . . . . & \end{array}$

Valid cases 
TB5A

Value Label

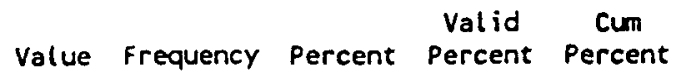

Total

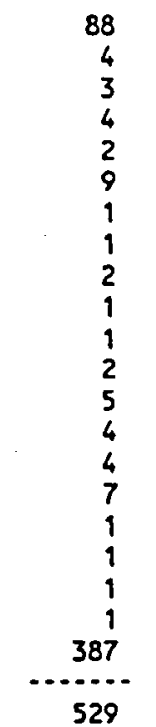

$$
\begin{array}{r}
16.6 \\
.8 \\
.6 \\
.8 \\
.4 \\
1.7 \\
.2 \\
.2 \\
.4 \\
.2 \\
.2 \\
.4 \\
.9 \\
.8 \\
.8 \\
1.3 \\
.2 \\
.2 \\
.2 \\
.2 \\
73.2 \\
\hline . . . \\
\hline 100.0
\end{array}
$$

62.0

2.8

2.1

2.8

1.4

6.3

.7

.7

1.4

.7

1.4

3.5

2.8

2.8

2.8
4.9

.7

.7

.7
.7

.7

.......

100.0

Valid cases

387

TB5B

Value Label

$\begin{array}{rrrrr}\text { Value } & \text { Frequency } & \text { Percent } & \begin{array}{c}\text { Valid } \\ \text { Percent }\end{array} & \begin{array}{c}\text { Cum } \\ \text { Percent }\end{array} \\ 0 & & & & \\ 1 & 81 & 15.3 & 57.0 & 57.0 \\ 2 & 4 & .8 & 2.8 & 59.9 \\ 3 & 8 & 1.5 & 5.6 & 65.5 \\ 4 & 7 & 1.3 & 4.9 & 70.4 \\ 5 & 3 & .6 & 2.1 & 72.5 \\ 6 & 3 & .6 & 2.1 & 74.6 \\ 7 & 6 & 1.1 & 4.2 & 78.9 \\ 8 & 3 & .6 & 2.1 & 81.0 \\ 9 & 1 & .2 & .7 & 81.7 \\ 10 & 4 & .8 & 2.8 & 84.5 \\ 11 & 5 & .9 & 3.5 & 88.0 \\ 12 & 2 & .4 & 1.4 & 89.4 \\ 13 & 1 & .2 & .7 & 90.1 \\ 14 & 2 & .4 & 1.4 & 91.5 \\ 15 & 1 & .2 & .7 & 92.3 \\ 17 & 2 & .4 & 1.4 & 93.7 \\ 18 & 1 & .2 & .7 & 94.4 \\ 19 & 1 & .2 & .7 & 95.1 \\ 20 & 1 & .2 & .7 & 95.8 \\ 23 & 1 & .2 & .7 & 96.5 \\ 25 & 1 & .2 & .7 & 97.2 \\ 30 & 1 & .2 & .7 & 97.9 \\ 70 & 2 & .4 & 1.4 & 99.3 \\ . & 1 & .2 & .7 & 100.0 \\ \text { Total } & . . .287 & 73.2 & \text { Missing } & \\ & 529 & 100.0 & 100.0 & \end{array}$

Valid cases 
APPENDIX C

DATA AND ANALYSIS OF DATA 
TBSC

Value Label

TB5D

Value Label

$\begin{array}{rrrrr}\text { Value } & \text { Frequency } & \text { Percent } & \begin{array}{c}\text { Valid } \\ \text { Percent }\end{array} & \begin{array}{c}\text { Cum } \\ \text { Percent }\end{array} \\ 0 & 95 & 18.0 & 66.9 & 66.9 \\ 1 & 7 & 1.3 & 4.9 & 71.8 \\ 2 & 7 & 1.3 & 4.9 & 76.8 \\ 3 & 9 & 1.7 & 6.3 & 83.1 \\ 4 & 2 & .4 & 1.4 & 84.5 \\ 5 & 2 & .4 & 1.4 & 85.9 \\ 6 & 1 & .2 & .7 & 86.6 \\ 7 & 2 & .4 & 1.4 & 88.0 \\ 9 & 2 & .4 & 1.4 & 89.4 \\ 10 & 1 & .2 & .7 & 90.1 \\ 11 & 1 & .2 & .7 & 90.8 \\ 12 & 4 & .8 & 2.8 & 93.7 \\ 14 & 1 & .2 & .7 & 94.4 \\ 15 & 4 & .8 & 2.8 & 97.2 \\ 19 & 1 & .2 & .7 & 97.9 \\ 20 & 1 & .2 & .7 & 98.6 \\ 90 & 2 & .4 & 1.4 & 100.0 \\ . & 387 & 73.2 & \text { Missing } & \\ \text { Total } & \ldots . . . & \ldots . . . & \ldots \ldots . . . & \end{array}$

Valid cases 
Page 25

TB5E

Value Label

TB5F

Value Label 142

$$
\text { Value Frequency Percent Palid } \begin{gathered}
\text { Cun } \\
\text { Percent Percent }
\end{gathered}
$$

$\begin{array}{lllll}0 & 95 & 18.0 & 66.9 & 66.9\end{array}$ $\begin{array}{lll}1.9 & 7.0 & 73.9\end{array}$ $1.1 \quad 4.2 \quad 78.2$ $1.1 \quad 4.2 \quad 82.4$ $.9 \quad 3.5 \quad 85.9$ $\begin{array}{lll}.4 & 1.4 & 87.3\end{array}$ $\begin{array}{lll}.8 & 2.8 & 90.1\end{array}$ $\begin{array}{lll}.6 & 2.1 & 92.3\end{array}$ $\begin{array}{lll}.4 & 1.4 & 93.7\end{array}$ $\begin{array}{lll}.6 & 2.1 & 95.8\end{array}$

$\begin{array}{lll}.2 & .7 & 96.5\end{array}$

$\begin{array}{lll}.2 & .7 & 97.2\end{array}$$$
\begin{array}{lll}
.2 & .7 & 97.9
\end{array}
$$$$
\begin{array}{lll}
.2 & .7 & 98.6
\end{array}
$$$$
\begin{array}{lll}
.2 & .7 & 90.3
\end{array}
$$$$
\begin{array}{lll}
.2 & .7 & 100.0
\end{array}
$$

Total

$$
\begin{array}{ccc}
387 & 73.2 & \text { Missing } \\
\hline 529 & 100.0 & 100.0
\end{array}
$$

387 
TB5G

Value Label

$\begin{array}{rrrrr}\text { Value } & \text { Frequency } & \text { Percent } & \begin{array}{c}\text { Valid } \\ \text { Percent }\end{array} & \begin{array}{c}\text { Cum } \\ \text { Percent }\end{array} \\ 0 & 90 & 17.0 & 63.4 & 63.4 \\ 1 & 12 & 2.3 & 8.5 & 71.8 \\ 2 & 6 & 1.9 & 4.2 & 76.1 \\ 3 & 4 & .8 & 2.8 & 78.9 \\ 5 & 2 & .4 & 1.4 & 80.3 \\ 6 & 3 & .6 & 2.1 & 82.4 \\ 7 & 5 & .9 & 3.5 & 85.9 \\ 8 & 4 & .8 & 2.8 & 88.7 \\ 9 & 3 & .6 & 2.1 & 90.8 \\ 10 & 4 & .8 & 2.8 & 93.7 \\ 12 & 4 & .8 & 2.8 & 96.5 \\ 14 & 1 & .2 & .7 & 97.2 \\ 15 & 1 & .2 & .7 & 97.9 \\ 18 & 3 & .6 & 2.1 & 100.0 \\ . & 387 & 73.2 & \text { Missing } & \\ \text { Total } & \ldots 2 . . & \ldots . . .8 & \ldots . . .9 & \end{array}$

TBSH

Value Label

Valid cases $\quad 142 \quad$ Missing cases $\quad 387$

Valid cases $\quad 142 \quad$ Missing cases $\quad 387$

$\begin{array}{rrrrrr}0 & 93 & 17.6 & 65.5 & 65.5 \\ 1 & 15 & 2.8 & 10.6 & 76.1 \\ 2 & 7 & 1.3 & 4.9 & 81.0 \\ 3 & 4 & .8 & 2.8 & 83.8 \\ 4 & 5 & .9 & 3.5 & 87.3 \\ 5 & 3 & .6 & 2.1 & 89.4 \\ 6 & 2 & .4 & 1.4 & 90.8 \\ 7 & 4 & .8 & 2.8 & 93.7 \\ 8 & 1 & .2 & .7 & 94.4 \\ 9 & 1 & .2 & .7 & 95.1 \\ 10 & 1 & .2 & .7 & 95.8 \\ 11 & 2 & .4 & 1.4 & 97.2 \\ 12 & 2 & .4 & 1.4 & 98.6 \\ 13 & 1 & .2 & .7 & 99.3 \\ 14 & 1 & .2 & .7 & 100.0 \\ & & 387 & 73.2 & \text { Missing } & \\ \text { Total } & 529 & 100.0 & 100.0 & \end{array}$

Valid cases $\quad 142 \quad$ Missing cases $\quad 387$ 
Page 27

TB5!

Value Label

TB5J

Value Label

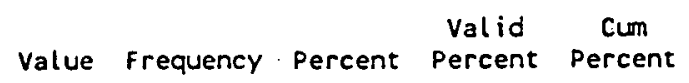

0
1
2
3
4
5
6
7
8
9
10
11
12
13
14
16
18
19
21
24
25

Total

\begin{tabular}{rrrr}
85 & 16.1 & 59.9 & 59.9 \\
12 & 2.3 & 8.5 & 68.3 \\
5 & .9 & 3.5 & 71.8 \\
5 & .9 & 3.5 & 75.4 \\
2 & .4 & 1.4 & 76.8 \\
2 & .4 & 1.4 & 78.2 \\
2 & .4 & 1.4 & 79.6 \\
1 & .2 & .7 & 80.3 \\
3 & .6 & 2.1 & 82.4 \\
1 & .2 & .7 & 83.1 \\
3 & .6 & 2.1 & 85.2 \\
1 & .2 & .7 & 85.9 \\
8 & 1.5 & 5.6 & 91.5 \\
1 & .2 & .7 & 92.3 \\
3 & .6 & 2.1 & 94.4 \\
2 & .4 & 1.4 & 95.8 \\
2 & .4 & 1.4 & 97.2 \\
1 & .2 & .7 & 97.9 \\
1 & .2 & .7 & 98.6 \\
1 & .2 & .7 & 99.3 \\
1 & .2 & .7 & 100.0 \\
387 & 73.2 & Missing & \\
$\ldots .$. & $\ldots \ldots$ & $\ldots . .$. & \\
\hline 529 & 100.0 & 100.0 &
\end{tabular}

Valid cases $142 \quad$ Missing cases 387

$\begin{array}{rrrrrr}0 & 95 & 18.0 & 66.9 & 66.9 \\ 1 & 14 & 2.6 & 9.9 & 76.8 \\ 2 & 3 & .6 & 2.1 & 78.9 \\ 4 & 1 & .2 & .7 & 79.6 \\ 5 & 7 & 1.3 & 4.9 & 84.5 \\ 6 & 2 & .4 & 1.4 & 85.9 \\ 7 & 4 & .8 & 2.8 & 88.7 \\ 8 & 3 & .6 & 2.1 & 90.8 \\ 9 & 1 & .2 & .7 & 91.5 \\ 10 & 1 & .2 & .7 & 92.3 \\ 11 & 1 & .2 & .7 & 93.0 \\ 12 & 1 & .2 & .7 & 93.7 \\ 13 & 1 & .2 & .7 & 94.4 \\ 15 & 1 & .2 & .7 & 95.1 \\ 16 & 2 & .4 & 1.4 & 96.5 \\ 17 & 2 & .4 & 1.4 & 97.9 \\ 18 & 2 & .4 & 1.4 & 99.3 \\ 22 & 1 & .2 & .7 & 100.0 \\ . & 387 & 73.2 & \text { Missing } & \\ \text { Total } & 529 & 100.0 & 100.0 & \end{array}$


Page 28

SPSS/PC+

$7 / 96 / 93$

TBGAA

Value Label

Value frequency percent Percent Percent

$\begin{array}{rrrrrr}0 & 119 & 22.5 & 83.8 & 83.8 \\ 1 & 10 & 1.9 & 7.0 & 90.8 \\ 2 & 4 & .8 & 2.8 & 93.7 \\ 3 & 3 & .6 & 2.1 & 95.8 \\ 4 & 5 & .9 & 3.5 & 99.3 \\ 8 & 1 & .2 & .7 & 100.0 \\ . & 387 & 73.2 & \text { Missing } & \\ & \ldots & \ldots & \ldots \\ \text { Total } & 529 & 100.0 & 100.0 & \end{array}$

Valid cases $142 \quad$ Missing cases $\quad 387$

TB6AB

Value Label

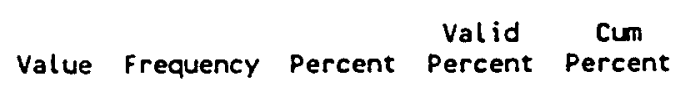

Valid cases $\quad 142 \quad$ Missing cases $\quad 387$

TBGAC

Value Label

$\begin{array}{rrrrr}0 & 105 & 19.8 & 73.9 & 73.9 \\ 1 & 3 & .6 & 2.1 & 76.1 \\ 2 & 9 & 1.7 & 6.3 & 82.4 \\ 3 & 10 & 1.9 & 7.0 & 89.4 \\ 4 & 3 & .6 & 2.1 & 91.5 \\ 5 & 2 & .4 & 1.4 & 93.0 \\ 6 & 2 & .4 & 1.4 & 94.4 \\ 7 & 1 & .2 & .7 & 95.1 \\ 8 & 6 & 1.1 & 4.2 & 99.3 \\ 9 & 1 & .2 & .7 & 100.0 \\ . & 387 & 73.2 & \text { Missing } & \\ \text { Total } & \ldots 2 . . & -\ldots . . . & -\ldots . . . & \end{array}$


Page 29

TBGAD

Value Label

$\begin{array}{rrrrr}\text { Value } & \text { Frequency } & \text { Vercent } & \begin{array}{c}\text { Valid } \\ \text { Percent }\end{array} & \begin{array}{c}\text { Cum } \\ \text { Percent }\end{array} \\ 0 & 84 & 15.9 & 59.2 & 59.2 \\ 1 & 3 & .6 & 2.1 & 61.3 \\ 2 & 4 & .8 & 2.8 & 64.1 \\ 3 & 13 & 2.5 & 9.2 & 73.2 \\ 4 & 6 & 1.1 & 4.2 & 77.5 \\ 5 & 8 & 1.5 & 5.6 & 83.1 \\ 7 & 5 & .9 & 3.5 & 86.6 \\ 8 & 7 & 1.3 & 4.9 & 91.5 \\ 9 & 3 & .6 & 2.1 & 93.7 \\ 10 & 5 & .9 & 3.5 & 97.2 \\ 11 & 1 & .2 & .7 & 97.9 \\ 12 & 1 & .2 & .7 & 98.6 \\ 15 & 1 & .2 & .7 & 99.3 \\ 25 & 1 & .2 & .7 & 100.0 \\ . & 387 & 73.2 & \text { Missing } & \\ \text { Total } & \ldots . . . & \ldots . . . & \ldots . . . . & \end{array}$

Valid cases $\quad 142 \quad$ Missing cases $\quad 387$

TBGAE

Value Label

$\begin{array}{rrrrr}\text { Value } & \text { Frequency } & \text { Percent } & \begin{array}{c}\text { Valid } \\ \text { Percent }\end{array} & \begin{array}{c}\text { Cum } \\ \text { Percent }\end{array} \\ 0 & 85 & 16.1 & 59.9 & 59.9 \\ 2 & 4 & .8 & 2.8 & 62.7 \\ 3 & 3 & .6 & 2.1 & 64.8 \\ 4 & 5 & .9 & 3.5 & 68.3 \\ 5 & 5 & .9 & 3.5 & 71.8 \\ 6 & 16 & 3.0 & 19.3 & 83.1 \\ 7 & 4 & .8 & 2.8 & 85.9 \\ 8 & 1 & .2 & .7 & 86.6 \\ 9 & 2 & .4 & 1.4 & 88.0 \\ 10 & 6 & 1.1 & 4.2 & 92.3 \\ 12 & 2 & .4 & 1.4 & 93.7 \\ 13 & 2 & .4 & 1.4 & 95.1 \\ 14 & 1 & .2 & .7 & 95.8 \\ 15 & 1 & .2 & .7 & 96.5 \\ 16 & 1 & .2 & .7 & 97.2 \\ 17 & 1 & .2 & .7 & 97.9 \\ 20 & 1 & .2 & .7 & 98.6 \\ 60 & 2 & .4 & 1.4 & 100.0 \\ . & 387 & 73.2 & \text { Missing } & \\ \text { Total } & \ldots . . . & \ldots . . . & \ldots . . . . & \end{array}$

Valid cases $\quad 142 \quad$ Missing cases 387 
Page 30

TB6BA

Value Label

Valid cases
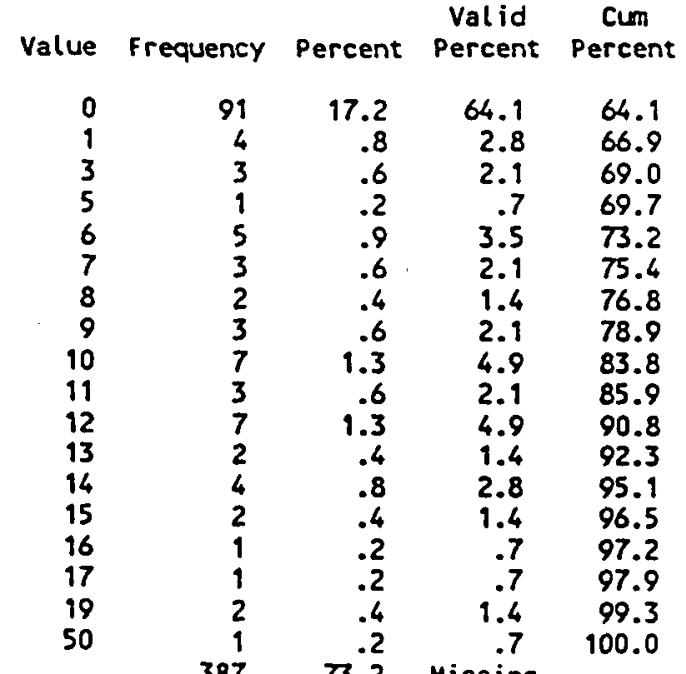

Total

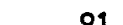

17.2

.8

.6

.2

.6

.0

.6

1.3

.6

1.3

.4

.8

.4
.2

.2

.2

73.2

100.0

64.1

2.8

2.1

66.9

69.0

$\begin{array}{ll}.7 & 69.7\end{array}$

$3.5 \quad 73.2$

$2.1 \quad 75.4$

$1.4 \quad 76.8$

2.178 .9

$4.9 \quad 83.8$

$2.1 \quad 85.9$

$4.9 \quad 90.8$

$1.4 \quad 92.3$

$2.8 \quad 95.1$

1.496 .5

97.2

97.9

$9.4 \quad 993$

$.7 \quad 100.0$

TB6BB

Value Label

$\begin{array}{rrrrr}\text { Value } & \text { Frequency } & \text { Percent } & \begin{array}{c}\text { Valid } \\ \text { Percent }\end{array} & \begin{array}{c}\text { Cum } \\ \text { Percent }\end{array} \\ 0 & 90 & 17.0 & 63.4 & 63.4 \\ 1 & 1 & .2 & .7 & 64.1 \\ 2 & 3 & .6 & 2.1 & 66.2 \\ 3 & 5 & .9 & 3.5 & 69.7 \\ 4 & 3 & .6 & 2.1 & 71.8 \\ 5 & 2 & .4 & 1.4 & 73.2 \\ 6 & 2 & .4 & 1.4 & 74.6 \\ 7 & 7 & 1.3 & 4.9 & 79.6 \\ 8 & 2 & .4 & 1.4 & 81.0 \\ 10 & 3 & .6 & 2.1 & 83.1 \\ 11 & 2 & .4 & 1.4 & 84.5 \\ 12 & 3 & .6 & 2.1 & 86.6 \\ 14 & 6 & 1.1 & 4.2 & 90.8 \\ 15 & 1 & .2 & .7 & 91.5 \\ 16 & 4 & .8 & 2.8 & 94.4 \\ 17 & 2 & .4 & 1.4 & 95.8 \\ 18 & 2 & .4 & 1.4 & 97.2 \\ 20 & 1 & .2 & .7 & 97.9 \\ 21 & 1 & .2 & .7 & 98.6 \\ 23 & 2 & .4 & 1.4 & 100.0 \\ . & 387 & 73.2 & \text { Missing } & \\ \text { Total } & \ldots . . . & . . .1 . & \ldots . . . . & \\ & 529 & 100.0 & 100.0 & \end{array}$

Valid cases 
Page 31

TB6CA

Value Label

\begin{tabular}{rrrrr} 
Value & Frequency & Percent & Percent & $\begin{array}{c}\text { Clm } \\
\text { Percent }\end{array}$ \\
0 & 76 & 14.4 & 53.5 & 53.5 \\
1 & 1 & .2 & .7 & 54.2 \\
2 & 2 & .4 & 1.4 & 55.6 \\
3 & 6 & 1.1 & 4.2 & 59.9 \\
5 & 2 & .4 & 1.4 & 61.3 \\
6 & 1 & .2 & .7 & 62.0 \\
7 & 1 & .2 & .7 & 62.7 \\
8 & 3 & .6 & 2.1 & 64.8 \\
9 & 1 & .2 & .7 & 65.5 \\
10 & 15 & 2.8 & 10.6 & 76.1 \\
11 & 2 & .4 & 1.4 & 77.5 \\
12 & 4 & .8 & 2.8 & 80.3 \\
13 & 7 & 1.3 & 4.9 & 85.2 \\
14 & 3 & .6 & 2.1 & 87.3 \\
15 & 4 & .8 & 2.8 & 90.1 \\
16 & 2 & .4 & 1.4 & 91.5 \\
18 & 2 & .4 & 1.4 & 93.0 \\
19 & 1 & .2 & .7 & 93.7 \\
20 & 4 & .8 & 2.8 & 96.5 \\
21 & 2 & .4 & 1.4 & 97.9 \\
23 & 1 & .2 & .7 & 98.6 \\
26 & 1 & .2 & .7 & 99.3 \\
50 & 1 & .2 & .7 & 100.0 \\
. & 387 & 73.2 & Missing \\
Total &..... &...... &..... & \\
\hline & 529 & 100.0 & 100.0 &
\end{tabular}

Valid cases $142 \quad$ Missing cases $\quad 387$ 
Page 32

TB6CB

Value Label

$\begin{array}{rrrrr}\text { Value } & \text { Frequency } & \text { Percent } & \begin{array}{c}\text { Valid } \\ \text { Percent }\end{array} & \begin{array}{c}\text { Cum } \\ \text { Percent }\end{array} \\ 0 & 78 & 14.7 & 54.9 & 54.9 \\ 2 & 3 & .6 & 2.1 & 57.0 \\ 3 & 3 & .6 & 2.1 & 59.2 \\ 4 & 4 & .8 & 2.8 & 62.0 \\ 5 & 4 & .8 & 2.8 & 64.8 \\ 6 & 3 & .6 & 2.1 & 66.9 \\ 7 & 1 & .2 & .7 & 67.6 \\ 8 & 1 & .2 & .7 & 68.3 \\ 9 & 2 & .4 & 1.4 & 69.7 \\ 10 & 5 & .9 & 3.5 & 73.2 \\ 11 & 8 & 1.5 & 5.6 & 78.9 \\ 12 & 8 & 1.5 & 5.6 & 84.5 \\ 13 & 5 & .9 & 3.5 & 88.0 \\ 14 & 1 & .2 & .7 & 88.7 \\ 15 & 4 & .8 & 2.8 & 91.5 \\ 17 & 2 & .4 & 1.4 & 93.0 \\ 19 & 5 & .9 & 3.5 & 96.5 \\ 21 & 1 & .2 & .7 & 97.2 \\ 23 & 1 & .2 & .7 & 97.9 \\ 24 & 1 & .2 & .7 & 98.6 \\ 40 & 1 & .2 & .7 & 99.3 \\ 81 & 1 & .2 & .7 & 100.0 \\ . & 387 & 73.2 & \text { Missing } & \\ & . . .2 & . . .5 & \ldots . . . & \\ \text { Total } & 529 & 100.0 & 100.0 & \end{array}$

Valid cases

Missing cases

387

TB601A

Value Label

$\begin{array}{rrrrr}\text { Value } & \text { Frequency } & \text { Percent } & \begin{array}{c}\text { Valid } \\ \text { Percent }\end{array} & \begin{array}{c}\text { Cum } \\ \text { Percent }\end{array} \\ 0 & 90 & 17.0 & 63.4 & 63.4 \\ 1 & 2 & .4 & 1.4 & 64.8 \\ 2 & 4 & .8 & 2.8 & 67.6 \\ 3 & 6 & 1.1 & 4.2 & 71.8 \\ 4 & 4 & .8 & 2.8 & 74.6 \\ 5 & 13 & 2.5 & 9.2 & 83.8 \\ 6 & 4 & .8 & 2.8 & 86.6 \\ 7 & 1 & .2 & .7 & 87.3 \\ 8 & 6 & 1.1 & 4.2 & 91.5 \\ 9 & 4 & .8 & 2.8 & 94.4 \\ 10 & 2 & .4 & 1.4 & 95.8 \\ 11 & 2 & .4 & 1.4 & 97.2 \\ 12 & 1 & .2 & .7 & 97.9 \\ 13 & 1 & .2 & .7 & 98.6 \\ 19 & 1 & .2 & .7 & 99.3 \\ 70 & 1 & .2 & .7 & 100.0 \\ . & 387 & 73.2 & \text { Missing } & \\ \text { Total } & \ldots . . . & \ldots \ldots . . . & \ldots \ldots . . . & \end{array}$

Valid cases 
TB601B

Value Label

$\begin{array}{rrrrr}\text { Value } & \text { Frequency } & \text { Vercent } & \begin{array}{c}\text { Valid } \\ \text { Percent }\end{array} & \begin{array}{c}\text { Cum } \\ \text { Percent }\end{array} \\ 0 & 84 & 15.9 & 59.2 & 59.2 \\ 1 & 4 & .8 & 2.8 & 62.0 \\ 2 & 14 & 2.6 & 9.9 & 71.8 \\ 3 & 6 & 1.1 & 4.2 & 76.1 \\ 4 & 6 & 1.1 & 4.2 & 80.3 \\ 5 & 5 & .9 & 3.5 & 83.8 \\ 6 & 3 & .6 & 2.1 & 85.8 \\ 8 & 5 & .9 & 3.5 & 89.4 \\ 9 & 5 & .9 & 3.5 & 93.0 \\ 10 & 7 & 1.3 & 4.9 & 97.9 \\ 18 & 1 & .2 & .7 & 98.6 \\ 19 & 1 & .2 & .7 & 99.3 \\ 60 & 1 & .2 & .7 & 100.0 \\ . & 387 & 73.2 & \text { Missing } & \\ \text { Total } & \ldots . . . & \ldots \ldots . . . & \ldots . . . & \end{array}$

Valid cases

142

Missing cases

387

TB601C

Value Label

$\begin{array}{rrrrr}\text { Value } & \text { Frequency } & \text { Percent } & \begin{array}{c}\text { Valid } \\ \text { Percent }\end{array} & \begin{array}{c}\text { Cum } \\ \text { Percent }\end{array} \\ 0 & 92 & 17.4 & 64.8 & 64.8 \\ 1 & 3 & .6 & 2.1 & 66.9 \\ 2 & 7 & 1.3 & 4.9 & 71.8 \\ 3 & 9 & 1.7 & 6.3 & 78.2 \\ 4 & 8 & 1.5 & 5.6 & 83.8 \\ 5 & 3 & .6 & 2.1 & 85.9 \\ 6 & 4 & .8 & 2.8 & 88.7 \\ 7 & 4 & .8 & 2.8 & 91.5 \\ 8 & 3 & .6 & 2.1 & 93.7 \\ 9 & 1 & .2 & .7 & 94.4 \\ 10 & 3 & .6 & 2.1 & 96.5 \\ 11 & 2 & .4 & 1.4 & 97.9 \\ 12 & 2 & .4 & 1.4 & 99.3 \\ 17 & 1 & .2 & .7 & 100.0 \\ . & 387 & 73.2 & \text { Missing } & \\ \text { Total } & \ldots . . . . & \ldots . . .-. & \ldots . . . . & \end{array}$

Valid cases 
Page 34

TB6010

Value Label

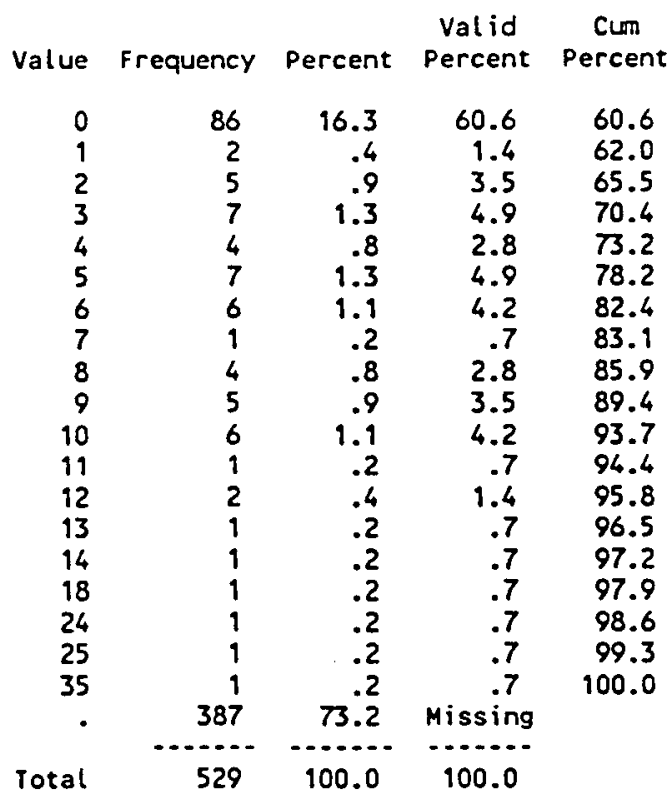

Valid cases

387

TB602A

Value Label

$\begin{array}{rrrrr}\text { Value } & \text { Frequency } & \text { Percent } & \begin{array}{c}\text { Valid } \\ \text { Percent }\end{array} & \begin{array}{c}\text { Cum } \\ \text { Percent }\end{array} \\ 0 & 82 & 15.5 & 57.7 & 57.7 \\ 1 & 3 & .6 & 2.1 & 59.9 \\ 2 & 5 & .9 & 3.5 & 63.4 \\ 3 & 2 & .4 & 1.4 & 64.8 \\ 4 & 2 & .4 & 1.4 & 66.2 \\ 5 & 9 & 1.7 & 6.3 & 72.5 \\ 6 & 3 & .6 & 2.1 & 74.6 \\ 7 & 2 & .4 & 1.4 & 76.1 \\ 8 & 5 & .9 & 3.5 & 79.6 \\ 9 & 5 & .9 & 3.5 & 83.1 \\ 10 & 6 & 1.1 & 4.2 & 87.3 \\ 11 & 2 & .4 & 1.4 & 88.7 \\ 12 & 5 & .9 & 3.5 & 92.3 \\ 13 & 3 & .6 & 2.1 & 94.4 \\ 14 & 2 & .4 & 1.4 & 95.8 \\ 15 & 1 & .2 & .7 & 96.5 \\ 17 & 1 & .2 & .7 & 97.2 \\ 18 & 2 & .4 & 1.4 & 98.6 \\ 20 & 1 & .2 & .7 & 99.3 \\ 90 & 1 & .2 & .7 & 100.0 \\ . & 387 & 73.2 & \text { Missing } & \\ \text { Total } & . . . . & \ldots . . . & \ldots . . .5 & \end{array}$

387 
Value Label

TB602C

Value Label

$\begin{array}{rrrrr}\text { Value } & \text { Frequency } & \text { Percent } & \text { Percent } & \text { Percent } \\ 0 & 96 & 18.1 & 67.6 & 67.6 \\ 1 & 2 & .4 & 1.4 & 69.0 \\ 2 & 9 & 1.7 & 6.3 & 75.4 \\ 3 & 6 & 1.1 & 4.2 & 79.6 \\ 4 & 2 & .4 & 1.4 & 81.0 \\ 5 & 4 & .8 & 2.8 & 83.8 \\ 6 & 4 & .8 & 2.8 & 86.6 \\ 7 & 1 & .2 & .7 & 87.3 \\ 8 & 5 & .9 & 3.5 & 90.8 \\ 9 & 2 & .4 & 1.4 & 92.3 \\ 10 & 4 & .8 & 2.8 & 95.1 \\ 11 & 3 & .6 & 2.1 & 97.2 \\ 12 & 1 & .2 & .7 & 97.9 \\ 13 & 1 & .2 & .7 & 98.6 \\ 17 & 1 & .2 & .7 & 99.3 \\ 20 & 1 & .2 & .7 & 100.0 \\ . & 387 & 73.2 & \text { Missing } & \\ \text { Total } & \ldots . . . & \ldots . . . & \ldots . . . & \end{array}$


186020

Value Label

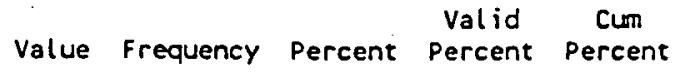

$\begin{array}{rrrrr}0 & 94 & 17.8 & 66.2 & 66.2 \\ 1 & 5 & .9 & 3.5 & 69.7 \\ 2 & 3 & .6 & 2.1 & 71.8 \\ 3 & 11 & 2.1 & 7.7 & 79.6 \\ 4 & 4 & .8 & 2.8 & 82.4 \\ 5 & 4 & .8 & 2.8 & 85.2 \\ 6 & 4 & .8 & 2.8 & 88.0 \\ 7 & 2 & .4 & 1.4 & 89.4 \\ 8 & 4 & .8 & 2.8 & 92.3 \\ 9 & 2 & .4 & 1.4 & 93.7 \\ 10 & 4 & .8 & 2.8 & 96.5 \\ 13 & 1 & .2 & .7 & 97.2 \\ 20 & 1 & .2 & .7 & 97.9 \\ 24 & 2 & .4 & 1.4 & 99.3 \\ 30 & 1 & .2 & .7 & 100.0 \\ . & 387 & 73.2 & \text { Missing } & \\ \text { Tota! } & 529 & 100.0 & 100.0 & \end{array}$

Valid cases $142 \quad$ Missing cases $\quad 387$

TB6EA

Value Label

\begin{tabular}{rrrrr} 
Value & Frequency & Percent & $\begin{array}{c}\text { Valid } \\
\text { Percent }\end{array}$ & $\begin{array}{c}\text { Cum } \\
\text { Percent }\end{array}$ \\
0 & 82 & 15.5 & 57.7 & 57.7 \\
1 & 4 & .8 & 2.8 & 60.6 \\
2 & 4 & .8 & 2.8 & 63.4 \\
3 & 3 & .6 & 2.1 & 65.5 \\
4 & 2 & .4 & 1.4 & 66.9 \\
5 & 5 & .9 & 3.5 & 70.4 \\
6 & 3 & .6 & 2.1 & 72.5 \\
7 & 3 & .6 & 2.1 & 74.6 \\
8 & 4 & .8 & 2.8 & 77.5 \\
9 & 7 & 1.3 & 4.9 & 82.4 \\
10 & 6 & 1.1 & 4.2 & 86.6 \\
12 & 2 & .4 & 1.4 & 88.0 \\
13 & 2 & .4 & 1.4 & 89.4 \\
14 & 4 & .8 & 2.8 & 92.3 \\
15 & 3 & .6 & 2.1 & 94.4 \\
17 & 2 & .4 & 1.4 & 95.8 \\
18 & 2 & .4 & 1.4 & 97.2 \\
21 & 1 & .2 & .7 & 97.9 \\
35 & 1 & .2 & .7 & 98.6 \\
37 & 1 & .2 & .7 & 99.3 \\
92 & 1 & .2 & .7 & 100.0 \\
\hline & 387 & 73.2 & Missing & \\
Total &.. .5 &...... & $\ldots . . .$. &
\end{tabular}

Valid cases 
Page 37

TB6EB

Value Label

$\begin{array}{rrrrr}\text { Value } & \text { Frequency } & \text { Percent } & \begin{array}{r}\text { Vatid } \\ \text { Percent }\end{array} & \begin{array}{c}\text { Cum } \\ \text { Percent }\end{array} \\ 0 & 83 & 15.7 & 58.5 & 58.5 \\ 1 & 1 & .2 & .7 & 59.2 \\ 2 & 3 & .6 & 2.1 & 61.3 \\ 3 & 5 & .9 & 3.5 & 64.8 \\ 4 & 7 & 1.3 & 4.9 & 69.7 \\ 5 & 9 & 1.7 & 6.3 & 76.1 \\ 6 & 3 & .6 & 2.1 & 78.2 \\ 7 & 1 & .2 & .7 & 78.9 \\ 8 & 8 & 1.5 & 5.6 & 84.5 \\ 9 & 3 & .6 & 2.1 & 86.6 \\ 10 & 5 & .9 & 3.5 & 90.1 \\ 11 & 3 & .6 & 2.1 & 92.3 \\ 12 & 1 & .2 & .7 & 93.0 \\ 13 & 1 & .2 & .7 & 93.7 \\ 14 & 2 & .4 & 1.4 & 95.1 \\ 15 & 3 & .6 & 2.1 & 97.2 \\ 16 & 1 & .2 & .7 & 97.9 \\ 18 & 1 & .2 & .7 & 98.6 \\ 20 & 1 & .2 & .7 & 99.3 \\ 22 & 1 & .2 & .7 & 100.0 \\ . & 387 & 73.2 & \text { Missing } & \\ \text { Total } & \ldots . . . . & . . .2 . & . . . . . & \end{array}$

Valid cases $\quad 142 \quad$ Missing cases $\quad 387$

TB6EC

Value Label

$\begin{array}{rrrrr}\text { Value } & \text { Frequency } & \text { Percent } & \begin{array}{c}\text { Valid } \\ \text { Percent }\end{array} & \begin{array}{c}\text { Cum } \\ \text { Percent }\end{array} \\ 0 & 107 & 20.2 & 75.4 & 75.4 \\ 1 & 2 & .4 & 1.4 & 76.8 \\ 2 & 1 & .2 & .7 & 77.5 \\ 3 & 3 & .6 & 2.1 & 79.6 \\ 4 & 3 & .6 & 2.9 & 81.7 \\ 5 & 4 & .8 & 2.8 & 84.5 \\ 6 & 3 & .6 & 2.1 & 86.6 \\ 8 & 3 & .6 & 2.1 & 88.7 \\ 9 & 1 & .2 & .7 & 89.4 \\ 10 & 3 & .6 & 2.1 & 91.5 \\ 11 & 2 & .4 & 1.4 & 93.0 \\ 12 & 3 & .6 & 2.1 & 95.1 \\ 13 & 3 & .6 & 2.1 & 97.2 \\ 16 & 1 & .2 & .7 & 97.9 \\ 18 & 1 & .2 & .7 & 98.6 \\ 20 & 1 & .2 & .7 & 99.3 \\ 50 & 1 & .2 & .7 & 100.0 \\ . & 387 & 73.2 & \text { Missing } & \\ \text { Total } & \ldots . . . & \ldots . . . & \ldots . . .- & \end{array}$

Valid cases 
P1

Value Label

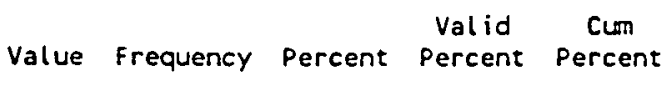

$\begin{array}{rrrrr}1 & 24 & 4.5 & 6.5 & 6.5 \\ 2 & 161 & 30.4 & 43.3 & 49.7 \\ 3 & 171 & 32.3 & 46.0 & 95.7 \\ 4 & 15 & 2.8 & 4.0 & 99.7 \\ 6 & 1 & .2 & .3 & 100.0 \\ 0 & 153 & 28.9 & \text { Missing } & \\ \text { Total } & 4 & .8 & \text { Missing } & \\ & 529 & 100.0 & 100.0 & \end{array}$

Valid cases $\quad 372 \quad$ Missing cases 157

P2

Value Label

$$
\text { Value frequency Percent Percent Percent }
$$

$\begin{array}{rrrrr}1 & 320 & 60.5 & 86.7 & 86.7 \\ 2 & 23 & 4.3 & 6.2 & 93.0 \\ 3 & 16 & 3.0 & 4.3 & 97.3 \\ 4 & 8 & 1.5 & 2.2 & 99.5 \\ 5 & 2 & .4 & .5 & 100.0 \\ 0 & 153 & 28.9 & \text { Missing } & \\ 0 & 7 & 1.3 & \text { Missing } & \\ & \ldots \ldots . . & -\ldots . . . & \ldots \ldots . . & \end{array}$

Valid cases $\quad 369 \quad$ Missing cases 160

P3

Value Label

$\begin{array}{rrrrr}\text { Value } & \text { Frequency } & \text { Percent } & \begin{array}{c}\text { Valid } \\ \text { Percent }\end{array} & \begin{array}{c}\text { Cum } \\ \text { Percent }\end{array} \\ 1 & 197 & 37.2 & 53.2 & 53.2 \\ 2 & 32 & 6.0 & 8.6 & 61.9 \\ 3 & 129 & 24.4 & 34.9 & 96.8 \\ 4 & 10 & 1.9 & 2.7 & 99.5 \\ 5 & 2 & .4 & .5 & 100.0 \\ 0 & 153 & 28.9 & \text { Missing } & \\ 0 & 6 & 1.1 & \text { Missing } & \\ \text { Total } & \ldots . . . & \ldots . . . & \ldots . . . . & \end{array}$

159 
Value Label

$$
\begin{array}{rrrrr}
\text { Value Frequency } & \text { Percent } & \begin{array}{c}
\text { Valid } \\
\text { Percent }
\end{array} & \begin{array}{c}
\text { Cum } \\
\text { Percent }
\end{array} \\
1 & 270 & 51.0 & 73.2 & 73.2 \\
2 & 38 & 7.2 & 10.3 & 83.5 \\
3 & 44 & 8.3 & 11.9 & 95.4 \\
4 & 17 & 3.2 & 4.6 & 100.0 \\
0 & 153 & 28.9 & \text { Missing } & \\
0 & 7 & 1.3 & \text { Missing } & \\
\text { Total } & \ldots 29 & 100.0 & 100.0 &
\end{array}
$$

Valid cases $\quad 369 \quad$ Missing cases 160
Value Label

A2

Value Label

$$
\begin{array}{rrrrr}
\text { Value } & \text { Frequency } & \text { Percent } & \begin{array}{c}
\text { Valid } \\
\text { Percent }
\end{array} & \begin{array}{c}
\text { Cum } \\
\text { Percent }
\end{array} \\
1 & & & & \\
2 & 9 & 1.7 & 81.8 & 81.8 \\
. & 518 & 97.9 & \text { Missing } & \\
\text { Total } & \ldots 29 & 100.0 & 100.0 &
\end{array}
$$

Valid cases $\quad 11 \quad$ Missing cases 518

A3

Value Label

$$
\begin{array}{rrrrr}
\text { Value Frequency } & \text { Percent } & \begin{array}{c}
\text { Valid } \\
\text { Percent }
\end{array} & \begin{array}{c}
\text { Cum } \\
\text { Percent }
\end{array} \\
1 & 4 & .8 & 36.4 & 36.4 \\
2 & 5 & .9 & 45.5 & 81.8 \\
4 & 1 & .2 & 9.1 & 90.9 \\
5 & 1 & .2 & 9.1 & 100.0 \\
. & 518 & 97.9 & \text { Missing } & \\
\text { Total } & 529 & 100.0 & 100.0 &
\end{array}
$$

Valid cases

Missing cases

518 
Page 40

A4

Value Label

$$
\text { Value frequency Percent Percent Percent }
$$

$\begin{array}{rrrrr}1 & 4 & .8 & 36.4 & 36.4 \\ 2 & 5 & .9 & 45.5 & 81.8 \\ 3 & 1 & .2 & 9.1 & 90.9 \\ 5 & 1 & .2 & 9.1 & 100.0 \\ . & 518 & 97.9 & \text { Missing } & \\ \text { Total } & 529 & 100.0 & : 00.0 & \end{array}$

Valid cases $\quad 11 \quad$ Missing cases 518

A5

Value Label Value frequency Percent Percent percent

\begin{tabular}{rrrrr}
1 & 7 & 1.3 & 63.6 & 63.6 \\
2 & 2 & .4 & 18.2 & 81.8 \\
3 & 1 & .2 & 9.1 & 90.9 \\
5 & 1 & .2 & 9.1 & 100.0 \\
. & 518 & 97.9 & Missing & \\
\hline Total & 529 & 100.0 & 100.0 &
\end{tabular}

Valid cases $11 \quad$ Missing cases $\quad 518$

A6

Value Label Value frequency percent Percent percent

$\begin{array}{rrrrr}1 & 4 & .8 & 36.4 & 36.4 \\ 2 & 4 & .8 & 36.4 & 72.7 \\ 3 & 2 & .4 & 18.2 & 90.9 \\ 4 & 1 & .2 & 9.1 & 100.0 \\ 1 & 518 & 97.9 & \text { Missing } & \\ \text { Total } & 529 & 100.0 & 100.0 & \end{array}$

Valid cases $11 \quad$ Missing cases 518

A7

Value Label

$\begin{array}{rrrrr}\text { Value } & \text { Frequency } & \text { Percent } & \begin{array}{c}\text { Valid } \\ \text { Percent }\end{array} & \begin{array}{c}\text { Cum } \\ \text { Percent }\end{array} \\ 1 & 5 & .9 & 45.5 & 45.5 \\ 2 & 5 & .9 & 45.5 & 90.9 \\ 4 & 1 & .2 & 9.1 & 100.0 \\ . & 518 & 97.9 & \text { Missing } & \\ \text { Total } & 529 & 100.0 & 100.0 & \end{array}$


A8

Value Label

$$
\text { Value frequency percent Percent percent }
$$

$\begin{array}{rrrrr}1 & 9 & 1.7 & 81.8 & 81.8 \\ 2 & 1 & .2 & 9.1 & 90.9 \\ 4 & 1 & .2 & 9.1 & 100.0 \\ . & 518 & 97.9 & \text { Missing } & \\ \text { Total } & \ldots \ldots & 100.0 & 100.0 & \end{array}$

Valid cases $\quad 11 \quad$ Missing cases 518

A9

Value Label
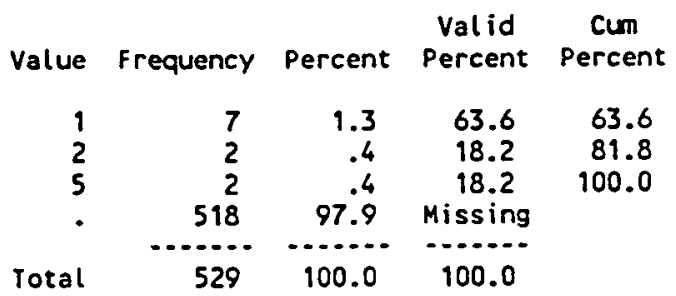

Valid cases $\quad 11 \quad$ Missing cases $\quad 518$

A10

Value Label
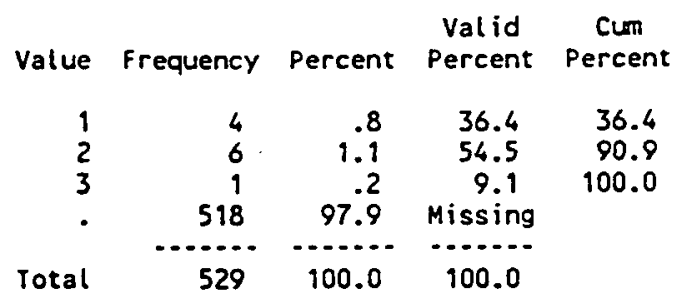

Valid cases $\quad 11 \quad$ Missing cases $\quad 518$

A11

Value Label

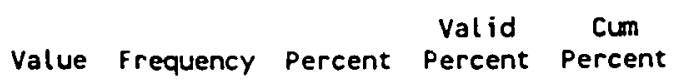

$\begin{array}{rrrrr}1 & 5 & .9 & 45.5 & 45.5 \\ 2 & 5 & .9 & 45.5 & 90.9 \\ 3 & 1 & .2 & 9.1 & 100.0 \\ . & 518 & 97.9 & \text { Missing } & \\ \text { Total } & 529 & 100.0 & 100.0 & \end{array}$

Valid cases $\quad 11 \quad$ Missing cases $\quad 518$ 


\section{7}

Page 42

SPSS/PC+

A12

Value Label

value Frequency Percent Percent Percent

$\begin{array}{rrrrr}1 & 5 & .9 & 45.5 & 45.5 \\ 2 & 1 & .2 & 9.1 & 54.5 \\ 3 & 1 & .2 & 9.1 & 63.6 \\ 5 & 4 & .8 & 36.4 & 100.0 \\ . & 518 & 97.9 & \text { Missing } & \\ \text { Total } & 529 & 100.0 & 100.0 & \end{array}$

Valid cases

11 Missing cases

518

A13

Value Label

$$
\text { Value Frequency Percent Percent percent }
$$

$\begin{array}{rrrrr}1 & 1 & .2 & 9.1 & 9.1 \\ 2 & 4 & .8 & 36.4 & 45.5 \\ 3 & 3 & .6 & 27.3 & 72.7 \\ 4 & 2 & .4 & 18.2 & 90.9 \\ 5 & 1 & .2 & 9.1 & 100.0 \\ . & 518 & 97.9 & \text { Missing } & \\ \text { Total } & 529 & 100.0 & 100.0 & \end{array}$

Valid cases $\quad 91 \quad$ Missing cases $\quad 518$

A14

Vatue Label

$$
\text { Value frequency Percent Percent Percent }
$$

$\begin{array}{rrrrr}1 & 3 & .6 & 33.3 & 33.3 \\ 2 & 4 & .8 & 44.4 & 77.8 \\ 4 & 1 & .2 & 11.1 & 88.9 \\ 5 & 1 & .2 & 11.1 & 100.0 \\ 0 & 518 & 97.9 & \text { Missing } & \\ \text { Total } & 2 & .4 & \text { Missing } & \\ & 529 & 100.0 & 100.0 & \end{array}$

Valid cases $\quad 9 \quad$ Missing cases $\quad 520$ 
Value Label

$\begin{array}{rrrrr}\text { Value } & \text { Frequency } & \text { Percent } & \begin{array}{c}\text { Valid } \\ \text { Percent }\end{array} & \begin{array}{c}\text { Cum } \\ \text { Percent }\end{array} \\ 1 & & & & \\ 2 & 5 & .9 & 50.0 & 50.0 \\ 4 & 3 & .6 & 30.0 & 80.0 \\ 5 & 1 & .2 & 10.0 & 90.0 \\ \text { i } & 1 & .2 & 10.0 & 100.0 \\ & 518 & 97.9 & \text { Missing } & \\ \text { Total } & 1 & .2 & \text { Missing } & \\ & 529 & 100.0 & 100.0 & \end{array}$

Valid cases ' $10 \quad$ Missing cases 519

A16

Value Label

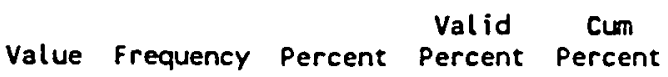

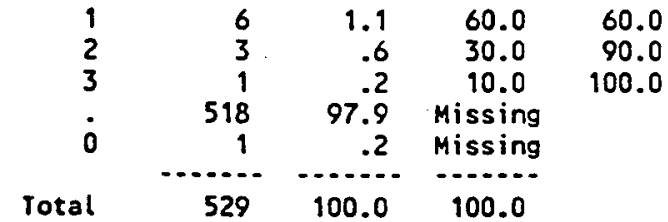

Valid cases $\quad 10 \quad$ Missing cases $\quad 519$

A17

Value Label

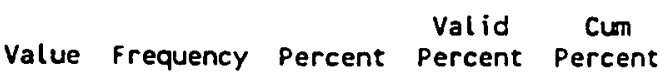

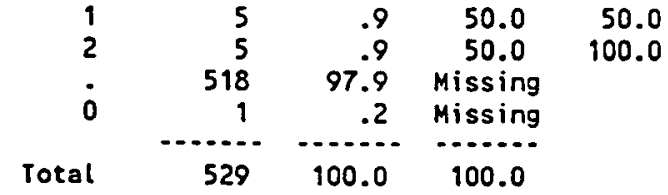

Valid cases $\quad 10 \quad$ Missing cases 519

A18

Value Label

Value Frequency Percent Percent percent

$\begin{array}{rrrrr}1 & 2 & .4 & 20.0 & 20.0 \\ 2 & 5 & .9 & 50.0 & 70.0 \\ 3 & 1 & .2 & 10.0 & 80.0 \\ 4 & 1 & .2 & 10.0 & 90.0 \\ 5 & 1 & .2 & 10.0 & 100.0 \\ 0 & 518 & 97.9 & \text { Missing } & \\ \text { Total } & 1 & .2 & \text { Missing } & \\ & 529 & 100.0 & 100.0 & \end{array}$


A19

Value Label

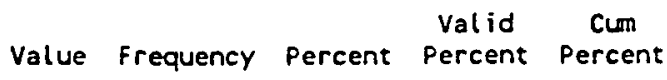

$\begin{array}{rrrrrr}1 & 7 & 1.3 & 70.0 & 70.0 \\ 2 & 2 & .4 & 20.0 & 90.0 \\ 3 & 1 & .2 & 10.0 & 100.0 \\ 0 & 518 & 97.9 & \text { Missing } & \\ 0 & 1 & .2 & \text { Missing } & \\ & \ldots \ldots & \ldots & \ldots\end{array}$

Valid cases $\quad 10 \quad$ Missing cases 519

A20

Value Label

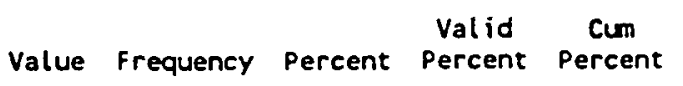

A21

Value Label

$\begin{array}{rrrrr}1 & 5 & .9 & 50.0 & 50.0 \\ 2 & 3 & .6 & 30.0 & 80.0 \\ 3 & 1 & .2 & 10.0 & 90.0 \\ 5 & 1 & .2 & 10.0 & 100.0 \\ 0 & 518 & 97.9 & \text { Missing } & \\ \text { Total } & 1 & .2 & \text { Missing } & \\ & 529 & 100.0 & 100.0 . & \end{array}$

Valid cases $\quad 10 \quad$ Missing cases $\quad 519$

Value Frequency Percent Percent Percent

$\begin{array}{rrrrr}1 & 5 & .9 & 50.0 & 50.0 \\ 2 & 4 & .8 & 40.0 & 90.0 \\ 5 & 1 & .2 & 10.0 & 100.0 \\ 0 & 518 & 97.9 & \text { Missing } & \\ \text { Total } & 1 & .2 & \text { Missing } & \\ & 529 & 100.0 & 100.0 & \end{array}$

Valid cases $\quad 10 \quad$ Missing cases 519

A22

Value Label

Value Frequency percent Percent Percent

$\begin{array}{rrrrr}1 & 4 & .8 & 40.0 & 40.0 \\ 2 & 6 & 1.1 & 60.0 & 100.0 \\ 0 & 518 & 97.9 & \begin{array}{r}\text { Missing } \\ \text { Missing }\end{array} \\ \text { Total } & 1 & .2 & \ldots & \\ & 529 & 100.0 & 100.0 & \end{array}$

Valid cases $\quad 10 \quad$ Missing cases $\quad 519$ 
Value Label

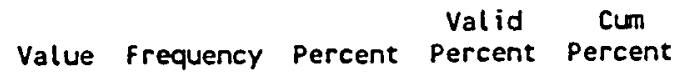

A24

Value Label

$$
\begin{array}{rrrrr}
\text { Value } & \text { Frequency } & \text { Vercent } & \begin{array}{c}
\text { Valid } \\
\text { Percent }
\end{array} & \begin{array}{c}
\text { Cum } \\
\text { Percent }
\end{array} \\
1 & 5 & .9 & 55.6 & 55.6 \\
2 & 3 & .6 & 33.3 & 88.9 \\
3 & 1 & .2 & 11.1 & 100.0 \\
\text { 0 } & 518 & 97.9 & \text { Missing } & \\
\text { rotal } & 2 & .4 & \text { Missing } & \\
& 529 & 100.0 & 100.0 &
\end{array}
$$

Valid cases 9 Missing cases 520

A25

Value Label

A26

Value Label

Valid cases $\quad 9$ Missing cases 520

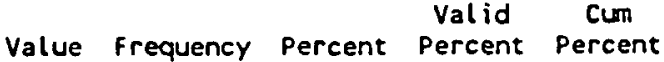

$$
\begin{array}{rrrrr}
1 & 6 & 1.1 & 66.7 & 66.7 \\
2 & 3 & .6 & 33.3 & 100.0 \\
0 & 518 & 97.9 & \begin{array}{r}
\text { Missing } \\
\text { Missing }
\end{array} \\
& 2 & .4 & \\
\text { Total } & 529 & 100.0 & 100.0 &
\end{array}
$$

Value Frequency Percent percent percent

$\begin{array}{rrrrr}1 & 4 & .8 & 44.4 & 44.4 \\ 2 & 5 & .9 & 55.6 & 100.0 \\ 0 & 518 & 97.9 & \text { Missing } & \\ 0 & 2 & .4 & \text { Missing } & \\ \text { Total } & 529 & 100.0 & 100.0 & \end{array}$

Valid cases

9

Missing cases

520 
A27

Value Label

$$
\text { Value Frequency Percent Percent Percent }
$$

$\begin{array}{rrrrr}1 & 3 & .6 & 33.3 & 33.3 \\ 2 & 5 & .9 & 55.6 & 88.9 \\ 3 & 1 & .2 & 11.1 & 100.0 \\ 0 & 518 & 97.9 & \text { Missing } & \\ \text { Total } & 2 & .4 & \text { Missing } & \\ & 529 & 100.0 & 100.0 & \end{array}$

Valid cases

9

Missing cases

520

A28

Value Label

$\begin{array}{rrrrr}\text { Value Frequency } & \text { Percent } & \begin{array}{c}\text { Valid } \\ \text { Percent }\end{array} & \begin{array}{c}\text { Cum } \\ \text { Percent }\end{array} \\ 1 & 3 & .6 & 33.3 & 33.3 \\ 2 & 6 & 1.1 & 66.7 & 100.0 \\ \text { 0 } & 518 & 97.9 & \text { Missing } & \\ & 2 & .4 & \text { Missing } & \\ \text { Totat } & 529 & 100.0 & 100.0 & \end{array}$

Valid cases

Missing cases

520 
Page 47

SPSS/PC+

$7 / 16 / 93$

This procedure was completed at 12:53:53

des all.

Page 48

SPSS/PC+

$7 / 16 / 93$

Number of Valid Observations (Listwise) = .00

Variable

$$
\text { Mean }
$$

Std Dev

Minimum

Maximum

N Label

ID

265.26

3.60

152.98

2.08

1.73

6.94

3.19

3.00

T5A

TSB

TSC

1.86

2.14

2.13

3.87

TSE

T6
T7A

T7A
T7B

T7C

T7D

T7E

T7F

T8
T9

TB2

TB3A

TB3B

TB3C

TB3D

TB4A

TB4B

TB4C

TB4D

TBLE

TBSA

TB5B

TBSC

TBSD

TBSE

TBSF

TESG

TBSH

TB5I

TB5J

TBGAA

TBGAB

TBGAC

TBGAD

TBGAE

TB6BA

TB6BB

T86CA

TB6CB

TB601A

2.52

.40

.28

.23

.39

.21

2.66

2.72

14.87

3.51

9.30

1.04

.76

4.17

.79

1.56

.93

1.40

1.51

1.41

.68

.49

.45

.42

.49

.41
.65

1.02

1.03

14.45

7.80

10.91

.20

3.42

2.51

7.60

.68

5.40

7.63

3.12

7.85

3.93

5.90

1.56

8.17

4.04

8.59

4.05

1.85

8.31

3.28

7.20

11.24

1.80

3.62

2.36

1.89

4.28

3.05

1.52

3.21

2.23

5.70

4.64

1.12

2.16

1.05

1.50

2.43

3.69

3.75

3.73

5.63

2.85

3.90

8.04

6.62

6.10

7.84

5.58

9.53

6.72

6.07

2.60

1.89

3.30

5.38

3.01
4.06

8.84

2.51

5.96

TB602B

2.04

3.83

4.80

4.61

9.85

4.96

3.30

5.82

.70

2.49

1.24

1.89

.68
1.01

P2

P3
P4

A1

A2

1.48

1.91

1.18

2.09

.88
.83

.40

1.30

$\begin{array}{lll}1 & 530 \quad 529\end{array}$

$6 \quad 115$

$\begin{array}{lll}1 & 4 & 142 \\ 1 & 33 & 142\end{array}$

1

142
28

58

84

48

30

141

142

142

142

142

142

142

140

142

142

142

142

142

142

142

142

142

142

142

142

142

142

142

142

142

142

142

142

142

142

142

142

142

142

142

142

142

142

142

142

142

142

142

142

142

142

142

142

372

369

370

369

11

11

A3 
Page 49

SPSS/PC+

$7 / 16 / 93$

Number of Valid Observations (Listwise) = .00 .

$\begin{array}{lrrrrr}\text { Variable } & \text { Mean } & \text { Std Dev } & \text { Minimum } & \text { Maximum } & N \text { Label } \\ \text { A4 } & 2.00 & 1.18 & 1 & 5 & 11 \\ \text { A5 } & 1.73 & 1.27 & 1 & 5 & 11 \\ \text { A6 } & 2.00 & 1.00 & 1 & 4 & 11 \\ \text { A7 } & 1.73 & .90 & 1 & 4 & 11 \\ \text { A8 } & 1.36 & .92 & 1 & 4 & 11 \\ \text { A9 } & 1.91 & 1.58 & 1 & 5 & 11 \\ \text { A10 } & 1.73 & .65 & 1 & 3 & 11 \\ \text { A11 } & 1.64 & .67 & 1 & 3 & 11 \\ \text { A12 } & 2.73 & 1.90 & 1 & 5 & 11 \\ \text { A13 } & 2.82 & 1.17 & 1 & 5 & 11 \\ \text { A14 } & 2.22 & 1.39 & 1 & 5 & 9 \\ \text { A15 } & 2.00 & 1.49 & 1 & 5 & 10 \\ \text { A16 } & 1.50 & .71 & 1 & 3 & 10 \\ \text { A17 } & 1.50 & .53 & 1 & 2 & 10 \\ \text { A18 } & 2.40 & 1.26 & 1 & 5 & 10 \\ \text { A19 } & 1.40 & .70 & 1 & 3 & 10 \\ \text { A20 } & 1.90 & 1.29 & 1 & 5 & 10 \\ \text { A21 } & 1.80 & 1.23 & 1 & 5 & 10 \\ \text { A22 } & 1.60 & .52 & 1 & 2 & 10 \\ \text { A23 } & 1.60 & .52 & 1 & 2 & 10 \\ \text { A24 } & 1.56 & .73 & 1 & 3 & 9 \\ \text { A25 } & 1.33 & .50 & 1 & 2 & 9 \\ \text { A26 } & 1.56 & .53 & 1 & 2 & 9 \\ \text { A27 } & 1.78 & .67 & 1 & 3 & 9 \\ \text { A28 } & 1.67 & .50 & 1 & 2 & 9\end{array}$


This procedure was completed at 12:53:56

compute tchange $=0$.

if $(t 4=1$ or $t 4=2)$ tchange $=$ tchange +2 .

if $(t 6=1$ ) tchange $=$ tchange +2 .

if $(t 8=1$ or $t g=2)$ tchange $=t$ change +2 .

if $(t g=1$ or $t 9=2)$ tchange=tchanget 2 .

if $(t<=3$ ) tchange $=$ tchange +1 .

if $(t 6=2$ ) tchange=tchange +1 .

if $(t 8=3 \quad)$ tchange $=$ tchange + .

if $(t 9=3 \quad)$ tchange=tchange +1 .

compute pchange $=0$.

if $(p)=2$ or $p 1=3$ ) pchange=pchange 2 .

if $(p 2=1$ or $p 2=2$ ) pchange=pchange +2 .

if $(p 3=1$ or $p 3=3)$ pchange=pchange+2.

if ( $p_{4}=1$ or $p_{4}=2$ or $p_{4}=3$ ) pchange=pchange+2.

if $(p 1=1$ ) pchange=pchange 1 .

if $\langle p 2=3 \quad$ ) pchange=pchange+1.

if $\langle p 3=4 \quad$ ) pchange=pchange +1 .

compute achange $=0$.

if $(a 3=1$ or $a 3=2$ ) achange=achange +2 .

if $(a 14=1$ or $a 14=2)$ achange=achange +2 .

if $(a 16=1$ or $a 16=2)$ achange=achange +2 .

if $(a 22=1$ or $a 22=2$ ) achange=achange +2 .

if $(a 3=5$ ) achange=achange +1 .

if $($ a $14=5$ ) achange=achange +1 .

if (a16=5 ) achange=achanget 1 .

if $(a 22=5$ ) achange=achange +1 .

count ntchange $=t 4$ t6 t8 t9 (9 thru hi).

count npchange $=p 1 p^{2} p^{3} p 4$ (1 thru hi).

count nachange $=a 3$ a14 a16 a22 (1 thru $h i$ ).

if (ntchange $=4$ ) change $=$ tchange.

if (npchange=4) change=pchange.

if (nachange $=4$ ) change=achange.

process if ntchange $=4$.

fre tchange/stat mean.

The raw data or transformation pass is proceeding

529 cases are written to the compressed active file.

\#\#* Memory allows a total of 32767 Values, accumulated across all Variables. There also may be up to 4096 Value Labels for each Variable. 
Page 56

SPSS/PC+

This procedure was completed at 12:54:04

fre change/stat mean.

\#*** Memory allows a total of 32767 Values, accumulated across all Variables. There also may be up to 4096 Value Labels for each Variable.

Page 57

SPSS/PC+

CHANGE

Value Label

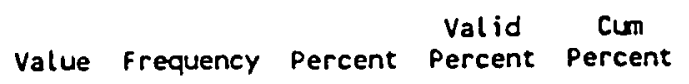

\begin{tabular}{|c|c|c|c|}
\hline $\begin{array}{l}.00 \\
1.00 \\
2.00 \\
3.00 \\
4.00 \\
5.00 \\
6.00 \\
7.00 \\
8.00\end{array}$ & $\begin{array}{l}10 \\
13 \\
24 \\
22 \\
26 \\
24 \\
72 \\
48 \\
273\end{array}$ & $\begin{array}{r}1.9 \\
2.5 \\
4.5 \\
4.2 \\
4.9 \\
4.5 \\
13.6 \\
9.1 \\
51.6\end{array}$ & $\begin{array}{r}2.0 \\
2.5 \\
4.7 \\
4.3 \\
5.9 \\
4.7 \\
14.1 \\
9.4 \\
53.3\end{array}$ \\
\hline - & 17 & 3 & Missing \\
\hline Total & 529 & 100.0 & 100.0 \\
\hline
\end{tabular}

Mean

6.451

Valid cases

512

Missing cases

17 
This procedure was completed at 12:54:05

if (id>519 and id<525) group $=1$.

if (id>524 and id<528) group $=2$.

if (id>527) group $=3$.

value labels group 1 'K-2' 2 '3-4' 3 '5-6'.

count nitems=al to a28(1 thru highest).

select if (nitems $=28$ ).

recode al to $a 28(2=1)($ else $=0)$.

count sumfal to a28 (1).

t-test groups $=$ group $(1,2) /$ variable $=$ sum.

The raw data or transformation pass is proceeding

8 cases are written to the compressed active file.

T-IEST requires 72 BYTES of workspace for execution. 
Page 59

SPSS/PC+

$7 / 16 / 93$

$t$-tests for independent samples of GROUP

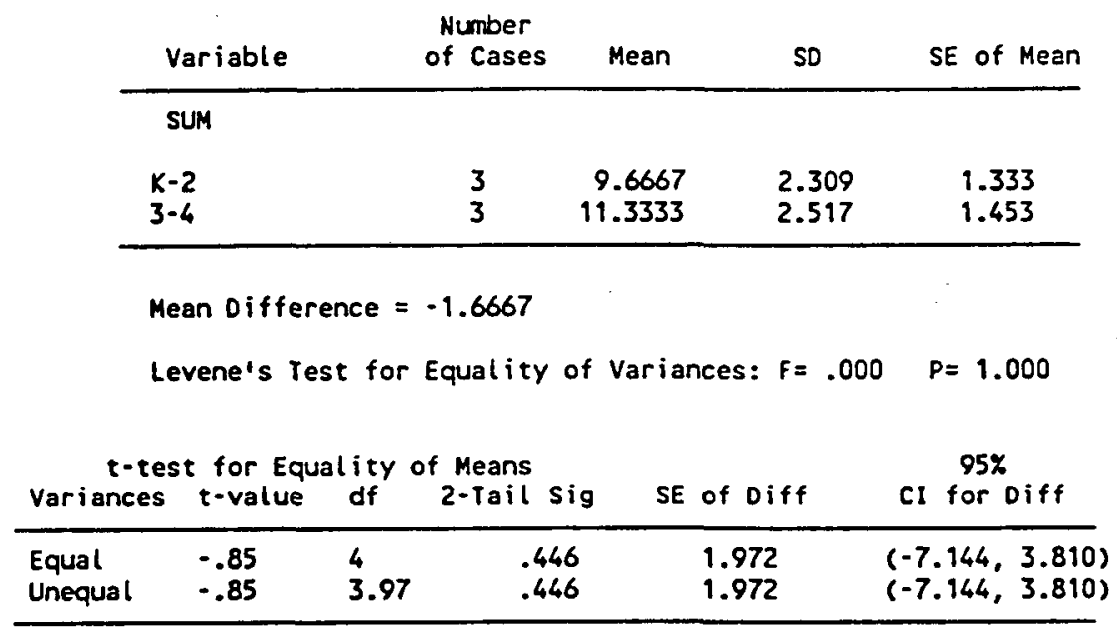


This procedure was completed at 12:54:08

$t$-test groups $=g$ roup $(1,3) /$ variablesum.

T-TEST requires 72 BYTES of workspace for execution.

Page 61 SPSS/PC+

$t$-tests for independent samples of GROUP

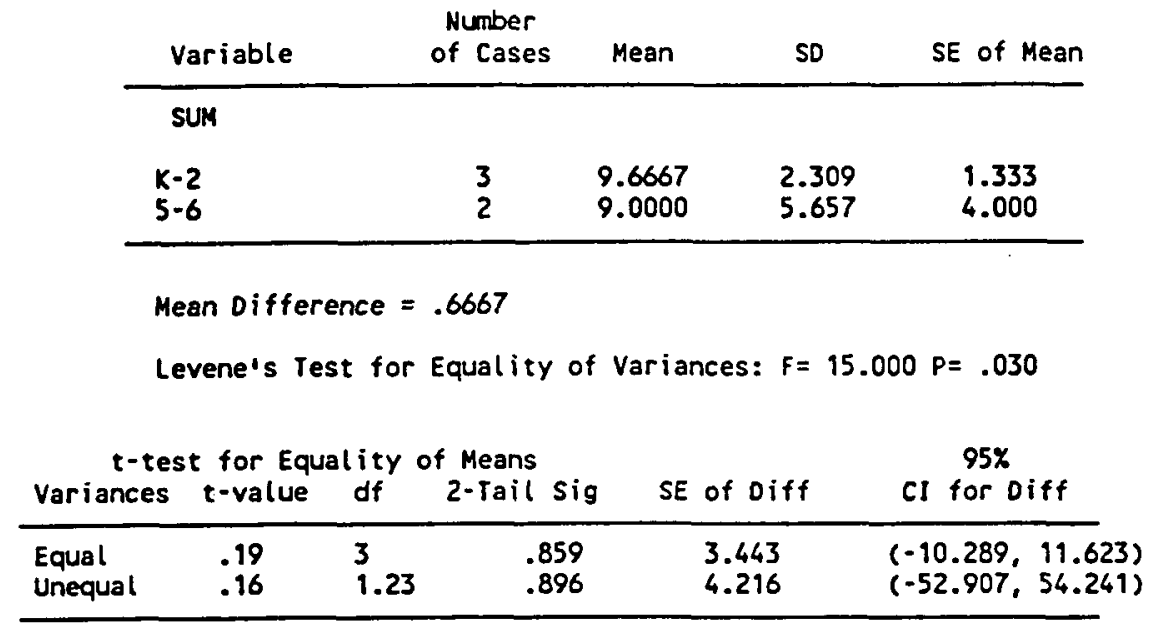


This procedure was completed at 12:54:08

$t$-test groups $=$ group $(2,3) / v a r i$ able $=$ sum.

T-TEST requires 72 BYTES of workspace for execution.

Page 63 SPSS/PC+

t-tests for independent samples of GROUP

\begin{tabular}{lllll} 
Variable & $\begin{array}{c}\text { Number } \\
\text { of Cases }\end{array}$ & Mean & SD & SE of Mean \\
\hline sur & & & & \\
$3-4$ & 3 & 11.3333 & 2.517 & 1.453 \\
$5-6$ & 2 & 9.0000 & 5.657 & 4.000 \\
\hline
\end{tabular}

Mean Difference $=2.3333$

Levene's Test for Equality of Variances: $F=5.581 \quad P=.099$

t-test for Equality of Means

95\%

\begin{tabular}{lccccc} 
Variances & t-value & df & $2-T a i l$ sig & SE of Diff & CI for Diff \\
\hline Equal & .66 & 3 & .555 & 3.522 & $(-8.877,13.543)$ \\
Unequal & .55 & 1.27 & .664 & 4.256 & $(-51.741,56.407)$
\end{tabular}


B I B L I O G R A P H Y 
Abu-Saad, I. (1991). Toward an understanding of minority education in Israel: The case of the Bedoin Arabs of the Negev. Journal Citation: Comparative Education, 27(2), 235-242.

Akbar, N. (1981). Cultural expressions of the African American child. Black Child Journal, 2(2), 10.

Akbar, N. (1985, December). Address before the Black Child Development Institute annual meeting. San Francisco.

Arnez, N. (1978). Implementation of desegration as a discriminating process. Journal of Negro Foundation, 16, 28-45.

Arnove, R. F., \& strout, T. (1980). Alternative schools for disruptive youth. Paper presented at the National Institute of Education/Educational Equity Group-School Social Relations, Chicago, Illinois.

Aslop, V. W. (1990). A framework for understanding why Black children fail in the early grades and their family dynamics: Part II. Social Casework, 46, 2335 .

Atkinson, J. W. (1983). An introduction to motivation in minority children's families. New York: Halsted Press.

Atkinson, P., \& Hord, F。 (1984). Save the children. office of Minority Affairs. Rosbury, MA: Minority Press.

Baratz, S. S., \& Baratz, J. C. (1969). Negro ghetto children and urban education: A cultural solution. Social Education, 33, 400-404.

Barone, F. J. (1993). The effects of part-time employment on academic performance. NASSP Bulletin, 8, 67 .

Bauch, B. A. (1982). Lay my burden down. Chicago: University Press. 
Bear, G. G., Clever, D., \& Proctor, W. A. (1991). Selfperceptions of nonhandicapped children and children with learning disabilities in integrated classes. Journal of Special Education, 24, 409-426.

Beck, J. (1975). How to raise a brighter child: The care for early learning. New York: Simon and Schuster.

Beck, M. S. (1991). Increasing school completion: Strategies that work. Athens, GA: The University of Georgia, Bureau of Educational Services.

Benton Harbor School System: Failure rate. (1992, october 2). The Herald Palladium, p. 3.

Blau, P. M., \& Duncan, O. D. (1977). The American occupational structure. New York: John Wiley.

Booker, B. C. (1995). Some strategies to implement African Americans' academic success. Washington, DC: Howard University Press.

Booker, C. B., \& Gary, L. E. (1992, October). Empowering African American children to achieve academic success. NASSP Bulletin, 76, 50 .

Boschee, F. (1989, May). Has the United States lost its competitive edge or commitment? NASSP Bulletin, 73, $517,78-82$.

Briggs, L. T. (1981). Instructional design: Principles and applications. Englewood Cliffs, NJ: Educational Technology Publications.

Brown, D. (1983). Truants, families and schools--A critique of the literature on truancy. Educational Review, $\underline{3}, 225-235$.

Burns, J. C. (1981, March). Increasing opportunities for minorities in school administration: The South Carolina model. NASSP Bulletin, 40, 91-93.

Campbell, B. M. (1985). A practical guide to the innercity open classroom. Pittsburg, PA: University of Pittsburg Press.

Campbell, B. M. (1994). What happened to the Afro? Ebony, pp. 79-106. 
Campbell, F. A., \& Ramey, C. T. (1994). Effects of early intervention on intellectual and academic achievement: A follow-up study of children from lowincome families. Child Development, 65, 684-698.

Carnegie Commission on Primary Education. (1988). The open door academic academies: Policies for alternative elementary schools. New York: McGraw-Hill Book Co.

Carnegie Corporation of New York. (1994). Starting points: Meeting the needs of our youngest children. New York: Carnegie Corporation of New York.

Cavazos, L. F. (1989). Educating our children: Parents and schools together. A report of the President. Washington, DC: US Department of Education.

Chachere, E. G., \& Johnston, K. B. (1982). A study of the attitudes toward public education of inner-city parents with children attending public schools. Handbook of data and definitions in primary education. New York: McGraw-Hill Book Co.

Chelsea's renaissance. (1990, June 21). Boston Globe, p. 18 .

Clark, R. M. (1984). Family life and school achievement: Why poor Black children succeed or fail. Chicago and London: The University of Chicago Press.

Clay, M. (1985). The early detection of reading difficulties (3rd ed.). Auckland, New Zealand: Heinemann Educational Books.

Clinton, W. (1995, January). Let us correct the epidemics which plague our young people. Washington, DC: State of the Union Address.

Cochran, M., \& others. (1982). The ecology of urban family life. Summary Report to the National Institute of Education. Boston: Boston University Press.

Cohen, A. M., \& Brawer, F. B. (1987). The collegiate function of primary education. San Francisco, CA: Jossey-Bass.

Cohen, M. (1989). Restructuring the system. Society, $\underline{26}(4), 40-46$. 
Coleman, J. S., \& Cooley, R. (1966). Equality of educational opportunity. Washington, DC: U.S. office of Education.

Comer, J. P. (1986). School power. New York: New American Library.

Comer, J. (1988). Educating poor minority children. Scientific American, 259, 42-48.

Conrath, J. (1989, Fall). Alternative schools vs. alternatives to school: Nine guidelines for a healthy alternative program. Educational Directions. NASSP Bulletin, $3,28-41$.

Coté, w. E. (1986). The Black child in crisis. Lansing: Professional Typesetting.

Curwood, S. (1983, November 2). Minorities face grim employment future. Chicago Sun Times, p. 74 .

Daniel, D. C. (1995, December). Bridging special and regular education: The Pennsylvania initiative. Educational Leadership, $\underline{52}(5), 44-47$.

Daniel, N., \& Cox, J. (1992, April). Toward intercultural harmony and balance in education-International education for high-ability students: An avenue to excellence. NASSP Bulletin, $\underline{8}, 43-45$.

Davis, D. A. (1989) . A creative approach toward greater equity in the whole land. Muncie, IN: Ball state University Press.

Davis, R. R. (1991). Learning how to learn: Technology, the seven multiple intelligences and learning. New York: Dutton.

Decker, L. E., \& Decker, V. A. (1988). Home/school community involvement. Arlington, VA: American Association of School Administrators. (ERIC Document Reproduction Service No. ED298610)

Diener, T. (1986). Growth of the American invention: A documentary history of the Academic Academy Movement. New York, NY: Greenwood Press.

Diop, C. A. (1985). The African origin of civilization: Myth or reality. Westport: Laurence Hill and Company. 
Dix, E. P. (1994). A nation at risk: The imperative for educational reform. Washington, DC: National Commission on Excellence in Education.

Dodd, J. (1993). The struggle to improve American education. Kansas City: Kansas city Press.

Dubois, W. E. B. (1961). The souls of Black folk. Greenwich, CT: Fawcett Publications.

Eastwold, P. (April, 1989). The dilemmas of educational excellence in the U.S.A.: Attendance is important: Combating truancy in the secondary school. NASSP Bulletin, 3,45 .

Edelman, M. W. (1993) The measure of our success. New York: Harper Collins Publishers.

Edmonds, R. (October, 1979). Effective schools for the urban poor. Educational Leadership, 17, 16-25.

Elam, S. M., \& Gallup, A. M. (September, 1990). The 21 t annual Gallup poll of the public's attitudes toward the public schools. Phi Delta Kappan, 31, 41-55.

Ellington, C. L. (1990). Academic Academy plan for Benton Harbor Primary Schools. Benton Harbor, MI: Schools Press.

Englander, M. (1986). Truancy and self-esteem. Paper presented at the annual meeting of the American Educational Research Association, San Francisco, CA.

Ferguson, W. K., \& Bruun, G. (1969). A survey of European civilization. New York: Houghton Mifflin.

Fordham, S., \& Ogbu, J. U. (1986). Black students' school success: Coping with the burden of 'acting white'. The Urban Review, 18, 176-206.

Frankel, S. (1989). Systems-oriented evaluation: A better approach to improving the achievement of minority students. Washington, DC: National Academy Press.

Frazier, E. F. (1939). The Negro Family in the United states. Chicago: University of Chicago Press.

Friere, P. (1980) . Pedagogy of the oppressed. New York: Continuum. 
Frymier, J. (1989). A study of students at risk. Bloomington, IN: Phi Delta Kappa Educational Foundation.

Gaither, T. J. (1990). A case study of the influences of political culture on institutional behavior and outcomes. ASHE Annual Meeting Paper. Reston, VA: National council of Teachers of Social Sciences.

Gary, E. L. (1994) Empowering African Americans to achieve academic success. Richmond: Virginia University.

Gerber, M. (1958, July). The psycho-motor development of African children in the first year, and the influence of maternal behavior. Journal of social Psychology, 47, 185-195.

Gerler, E. R., Jr., \& others. (1990). Learning in a changing world: Making mathematics and science work for Blacks and Hispanics. Washington, DC: American Association for the Advancement of Science.

Glasser, W. (1968). Schools without failure. New York: Harper and Row.

Glazer, B. (1989). Deprived child's intellect: Myth or reality. The discovery of grounded theory.

Chicago: Adline.

Gordon, M. (1978). Human nature, class, and ethnicity. New York: Oxford University Press.

Green, L., \& Washington, B. (1983, February 14) • Grim reality casts shadows over dreams. Chicago sun Times, pp. 27,36 .

Hale, J. (1982, January). Black children: Their roots, culture, and learning styles. Provo, UT: Brigham Young University Press.

Hale, J. (1984). A comparative study of the racial attitudes of Black children who attend a pan-African and a non-pan-African preschool. Ph.D. dissertation, Georgia state University Press.

Hale-Benson, J. (1986). Learning styles of African American children. Atlanta: Georgia state University Press. 
Hanson, J. R. (1989) . Learning styles, Types of intelligence and students at-risk: An argument for a broad-based curriculum. Research Monograph Series, Institute for Studies in Analytic Psychology. Romper Review, 4, 89 .

Hanson, J. R., \& Dewing, T. (1990). Research on the profiles of at-risk learners. Research Monograph Series, Institute for studies in Analytic Psychology. Romper Review, 23, 107.

Hanson, J. R., Dewing, T., Silver, H. F. \& strong, R. W. (1991, February). Research on the roles of intuition and feeling. Romper Review, 6 (3), 167170 .

Haas, J. (1992, April). The dilemmas of excellence: The struggle to improve American education. NASSP Bulletin, 76, 81-86.

Heilbrun, A. B., \& Waters, D. B. (1984) . Underachievement as related to perceived maternal childrearing and academic conditions of reinforcement, child development. New York: Free Press.

Herzog, E., \& Sudia, C. (1991). Children in fatherless families. Chicago: University of Chicago Press.

Higbee, J. L., \& Dwinell, P. L. (1990, Fall). The high risk student profile. Journal citation: Research and teaching in developmental education, $7(1)$, 5564 .

Hodgkinson, H. L. (1990). On the homefront: Demands for child care: A demographic look at tomorrow. washington, DC: Institute for Educational Leadership.

Holt, J. (1964). How children fail. Handbook of Data and Definitions in Primary Education, 8, 29.

Howe, H., \& Edelman, M. W. (1985). National Coalition of Advocates for students. Barriers to excellence: our children at risk. Boston: Boston University Press.

Huxley, T. H. (1992, April). In Jim Hass', Dilemmas of excellence. NASSP Bulletin, 86, 56 .

Isaac, S., \& Michael, W. B. (1981). Handbook in research and evaluation (2nd ed.). San Diego, CA: Edits Pub. 
Jackson, B. L., \& Cooper, B. S. (1992, April). Involving parents in improving urban schools. NASSP Bulletin, 76, 30 .

Jackson, S., \& others. (1988). Community collaboration ensures success for children and adult learners. NASSP Bulletin, 76, 28 .

Johnson, D. (1987) . Effects of cooperative competitive, and individualistic goal structures on achievement: A meta-analysis of cohesive education. Psychological Bulletin, 38, 47-62.

Johnson, D., Maruyama, G., Johnson, R., Nelson, D., \& Skon, L. (1981). Effects of cooperative, competitive, and individualistic goal structures on achievement: A meta-analysis of cohesive education. Psychological Bulletin, 89, 47-62.

Jones, R. (1982) . Selecting literature for Black preschool children in today's society. Black Child Journal, $4(1), 13-14$.

Karenga, M. (1982). Introduction to Black studies. Los Angeles: Kawaida Publications.

Knight, s. L., Waxman, H. C., \& Hersholt, T. (1990, May 12). Investigating the effects of the classroom learning environment on students' motivation in social studies. Educational Leadership, 14(1), 112 .

Kohn, A. (1993). Punished by rewards. boston: Houghton Mifflin.

Kunjufu, J. (1983). Developing positive self-images and discipline in African American students. African American Images, 9,201 .

Lange, P., \& Koos, J. (1991). Breaking the bonds of adult illiteracy in the U.S. ghettos equates freeing the prisoners of silence. New York: Continuum Press.

Lawrence, G. (1979). People types and tiger stripes: A practical quide to learning styles. Gainesville, FL: Center for the Application of Psychological Type.

Leichter, H. J., \& others. (1982). The role of the family in promoting children's acquisition of literacy for learning. New York: Doubleday. 
Levine, R. S. (1984). An assessment tool for early intervention in cases of truancy. Social Work in Education, $\underline{3}, 133-149$.

Lyons, C. A. (1989) . Reading recovery: A preventative for mislabeling young 'at-risk' learners. Urban Education, 24, 125-139.

Madden, N. A., Slavin, R. E., Karweit, N. L., Dolan, L. J., \& Wasik, B. A. (1993). Success for all: Longitudinal effects of restructuring program for inner-city elementary schools. American Educational Research Journal, 30, 123-148.

Margolin, E. (1988). Education reform: How to benefit from research and our experience with young children. NASSP Bulletin, 86, 28-40.

Maxwell, M. (1988). Improving student learning skills. Chicago: Chicago University Press.

McClelland, D. C., \& others. (1981). The creative spirit of an achieving society. Princeton, NJ: Van Nostrand.

McMillan, J.H. (1986) The Black child in crisis. Louisville, KY: University of Louisville Press.

Michaels, S. (1983, November). Sharing time: An oral preparation for literacy. National Assessment of Educational Progress, 18, 31-36.

Midkiff, R.-B., \& Abu-Saad, I. (1991). Learning styles needs of at-risk students: Teaching math and social studies the way they learn. NASSP Bulletin, 88, 1825 .

Miles, M., \& Louis, K. S. (1990). Improving the urban high school: What works and why. New York: Teachers College Press.

Mingle, J. R., \& Rodriguez, E. M. (Eds.) . (1990) . Building coalitions for minority success: A report of the SHEEO project on minority achievement in higher education. RASSP Bulletin, 71, 40-41.

Moles, o. C., Jr. (1980). Child training practices among low income families. Welfare in Review, $\underline{6}$, 91-108.

Montagu, A. (1954). Prenatal influences in brain formation. Ladies Home Journal, 181, 97-105. 
Morgan, H. (1980, January-February). How schools fail Black children. Social Policy, 10, 49-54.

Moyers, C. (1983, April), Child training practices among low-income families. Welfare in Review. $\underline{3}_{\text {, }}$ $48-62$.

Moynihan, D. P. (1965). The negro family: The case for national action. Washington, DC: Office of Policy Planning and Research, U.S. Department of Labor.

Myers, I. (1985). Manual: A quide to the development and use of the Myers Briggs Type Indicator. Palo Alto, CA: Consulting Psychologist Press.

Nathan, J. (1989, July) . Before adopting school choice, review what works and what fails. The American School Board Journal, 41, 28-31.

National Alliance of Black Educators. (1984, November). Saving the African American child. A report of the NABSE task force on Black academic and cultural excellence. Washington, DC: National Academy Press.

National Center for Education Statistics. (1991). The condition of education. Volume 1, Elementary and Secondary Education. Washington, DC: US Department of Education.

Natriello, G. (Ed.). (1986). School dropouts: Patterns and policies. New York: Teachers College Press.

Nedsker, L. L., \& Tillery, D. (1987). Breaking the access barriers: A profile of two-year college. New York: McGraw-Hill.

Newsome, E. (1990). W. E. B. Du Bois' figure in the carpet: A cyclical pattern in the Belletristic prose. Ph.D. dissertation, University of North Carolina.

Oakes, A. (1981). Nécessité et signification des recherches comparatives en psychologie génétique. International Journal of Psychology, $1,3-13$.

orr, M. T. (1987). Keeping students in school. San Francisco: Jossey-Bass Publishers.

Patton, J., \& McKay, B.'A. (1984). The minority achievement and participation effort in Montgomery county Public Schools. Baltimore, MD: Johns Hopkins University Press. 
Payne, C. M. (1984, June). Getting what we ask for: The ambiguity of success and failure in urban education. Contributions to the study of Education, No. 12. NASSP Bulletin, $\underline{54}, 22-35$.

Perkins, S. (1984). Satan in the pulpit: Emergence of gang activity. New York: Basic Books.

Phlegar, J. M. \& Rose, R. M. (1988) . At-risk students: Approaches to identification and intervention. Providence: Rhode Island Department of Elementary and secondary Education.

Pinnell, G. S., DeFord, D. E., \& Lyons, C. A. (1988). Reading recovery: Early intervention for at-risk first graders. Arlington, VA: Educational Research Service.

Pinnell, G. S., Lyons, C. A., DeFord, D. E., Bryk, A. S., \& Seltzer, M. (1994). Comparing instructional models for the literacy education of high-risk first graders. Reading Research Quarterly, 29, 9-40.

Postman, N. (1982). The disappearance of childhood. New York: Delacorte.

Reiff, H. B., \& others. (1990). Special education teacher training to prevent minority school dropouts in rural areas. NASSP Bulletin, 71, 16-21.

Richardson, R. B. (1988). Active affective learning for accelerated schools. Stanford, GA: Center for Educational Research at Stanford.

Rogers, E. M. (1983). Diffusion of innovations. New York: Free Press.

Rohrman, D. (1996). Combating truancy in our schools--A community effort. Upland, IN: Taylor University Press.

Rosenzweig, A. (1971, August) - Electrical currents in brain and nervous system. Scientific American, 27, 54 .

Ross, E. M., \& others. (1991). An evaluation of alternative distance tutoring models for at-risk elementary school children. NASSP Bulletin, 77, 5661.

Roumain, D. (1939). Les gouverneurs de la rosée. Portau-Prince: Imprimerie Deschamps. 
Schulz, W. E., \& Bravi, G. (1986, October). Classroom learning environment in North American schools. Journal of American Indian Education, 26(1), 23-31.

The score: Rome 1500, U.S. 200. (1976, August 23). Time, p. 59 .

Scott, W. G. (1973). Organization theory. An overview and an appraisal. Homewood, IL: Richard D. Irwin.

Seeley, J. (1989, August). Building a strong self-image in Black children. Ebony Magazine, 31, 138-143.

Sertima, I. V. (1989). Eqypt revisited. New Brunswick (USA) and London (U.K.): Transaction Publishers.

Shibutani, T., \& Kwan, K. M. (1965). A comparative approach. New York: Macmillan.

Silver, A. A., \& Hagin, R. A. (1990). Disorder of learning in childhood. New York: Wiley.

Silver, H. F., \& Hanson, J. R. (1988). Teaching styles and strategies. Moorestown, NJ: Hanson Silver strong \& Associates.

Simmons, W. (1994, March). The role of cultural salience in ethnic and social class differences in cognitive performance. National Assessment of Educational Progress, 37, 191-195.

Sklarz, D. P. (1989, September). Keep at-risk students in school by keeping them up to grade level. American School Board Journal, 18, 33-34.

Slavin, R. E. (1996, February). Preventing learning disabilities. Educational Leadership. Effingham, IL: World Color Press.

Slavin, R. E., Madden, N. A., Karweit, N. L., Dolan, L., Wasik, B. A., Shaw, A., Mainzer, K, L., \& Haxby, B. (1991). Neverstreaming: Prevention and early intervention as alternatives to special education. Journal of Learning Disabilities, 24, 373-378.

Slavin, R. E., Madden, N. A., Karweit, N. L., Dolan, L., \& Wasik, B. A. (1992). Success for all: A relentless approach to prevention and early intervention in elementary schools. Arlington, VA: Educational Research Service. 
Slavin, R. E., Madden, N. A., Karweit, N. L., Dolan, L. J., Wasik, B. A., Ross, S. M., \& Smith, L. J. (1994). 'Wherever and whenever we choose.. .': The replication of success for all. Phi Delta Kappan, 75(8), 6399-6647.

Slavin, R. E., Madden, N. A., Karweit, N. L., Dolan, L., \& Wasik, B. A. (1996). Every child, every school: Success for all. Newbury Park, CA: Corwin.

Smith, L. J., Ross, S. M. \& Casey, J. P. (1994) . Special education analysis for success for all in four cities. Memphis, TN: University of Memphis, Center of Research in Educational Policy.

Smith, M. T. \& Nance-Nash, S. (1989, July). The best places to live in the U.S.A. today. Money, 18, 4261.

Staten, T. V. (1990, March). Background and causes of "at-risk" children: They can succeed. Paper

presented at Dearborn, Michigan, at "Multi-cultural Caucus for Children's Success."

strong, R. W. , Silver, H. F., \& Hanson, J. R. (1982). Questioning styles and strategies. New York: Wiley strong and Associates.

The struggle to improve American education. (1988, April). Washington Post, p. 6 .

Sullivan, T. A. (1978). Racial-ethnic differences in labor force participation: An ethnic stratification perspective. In Frank D. Bean and W. P. Frisbie (Eds.), The demography of racial and ethnic groups, pp. 165-87. New York: Academic Press.

Swanson, A. D. (1989) . Restructuring educational governance: A challenge of the 1990s. Educational Administration Quarterly, 25, 268-293.

Swap, W. N. (1990). Black males: Reclamation, reascension and revitalisation. Chicago: Mosque of Islam Press.

Taylor, F., \& others. (1991). Teenage pregnancy: The problem that hasn't gone away. New York: Alan Guttmacher Institute.

Thurow, L. (1994, June). American education below par, compared to other industrial nations. Washington Post, 98, 38-39. 
Torgerson, J. L. (1994). Turning points: Preparing American youth for the 21st century. Washington, DC: National Assessment of Educational Progress.

Toynbee, A. J. (1947) . A study of history. New York: oxford University.

Turner, J. (1971). Black studies and a Black philosophy of education. Imani, 18, 12-17.

U.S. Department of Labor. (1989). Keeping the educational edge. Washington, DC: Bureau of Labor statistic Press Release.

Vasiloff, B. (1983, October). Discipline: The challenge of the 80s. Today's Catholic Teacher, p. 34 .

Wallace, F., \& Brunn, T. (1909). A survey of European civilization. New York: Houghton Mifflin.

Wehlage, G. G., Rutter, R., Smith, G. A., \& others. (1989). Reducing the risk: Schools as communities of support. London: Falmer Press.

Weikel, A. W. (1991). An introduction to ecological psychology. Monterey, CA: Brooks/Cole.

Welsing, F. C. (1991). The Isis Papers: The keys to the colors. Chicago: Third World Press.

White, E. G. (1952) - Education. Idaho: Pacific Press.

wilhelm, s. (1980) . Who needs the Negro? New York: Schenkman Publishers.

Williams, R. (1983). Black pride, academic relevance, and individual achievement. St. Louis: Robert williams and Associates.

williams, R. (1983). What did White America do to destroy the Black child? Rochester, NY: HEMA Publishing.

Williams, R. (1995). Why did White America choose to destroy the Black family? Rochester, NY: HEMA Publishing.

Williams, T. R. (1981). Abilities and environments: Another view. Boston: Little, Brown.

wilson, A. N. (1987). The developmental psychology of the Black child. New York: Africana Research Publications. 
Woodard, S. L. (1995). Achieving academic excellence in the urban environment: overcoming the odds. Washington, DC: Howard University Press.

woodson, C. G. (1933) - The miseducation of the Negro. Washington, DC: Associated Publishers.

Yannet, P. (1952, June). Dietary indiscretions by pregnant women negatively affect new-borns. Newsweek, 32, 17-21.

Ziesemer, c. (1984). Student and staff perceptions of truancy and court referrals. Social Work in Education, 3 , 167-177.

Zigler, E. F., Finn-Stevenson, M., \& Linkins, K. W. (1992). Meeting the needs of children and families with schools of 21 st century. Yale Law and Policy Review, 10(1), 69-81. 
VITA

NAME :

Simon Mathieu Honoré

DATE OF BIRTH: (optional)

PLACE OF BIRTH: Saint Louis du Nord, Haiti

EDUCATION :

1996

Doctor of Philosophy

Educational Administration and Supervision (cognate: Religious Education)

(tools: French and Spanish)

Andrews University

Berrien Springs, Michigan

1989 Specialist in Education

Educational Administration and Supervision (cognate: Religious Education)

Andrews University

Berrien Springs, Michigan

1988 Master of Arts

Educational Administration and Supervision Andrews University

Berrien Springs, Michigan

1981 Master of Arts

Religious Education

Andrews University

Berrien Springs, Michigan

1973 Licencié en Biochimie Humaine

Louis Pasteur University

Strasbourg, France

1969 Bachelor of Arts

Biology, Chemistry, and History

Andrews University

Berrien Springs, Michigan 
PROFESSIONAL EXPERIENCE:

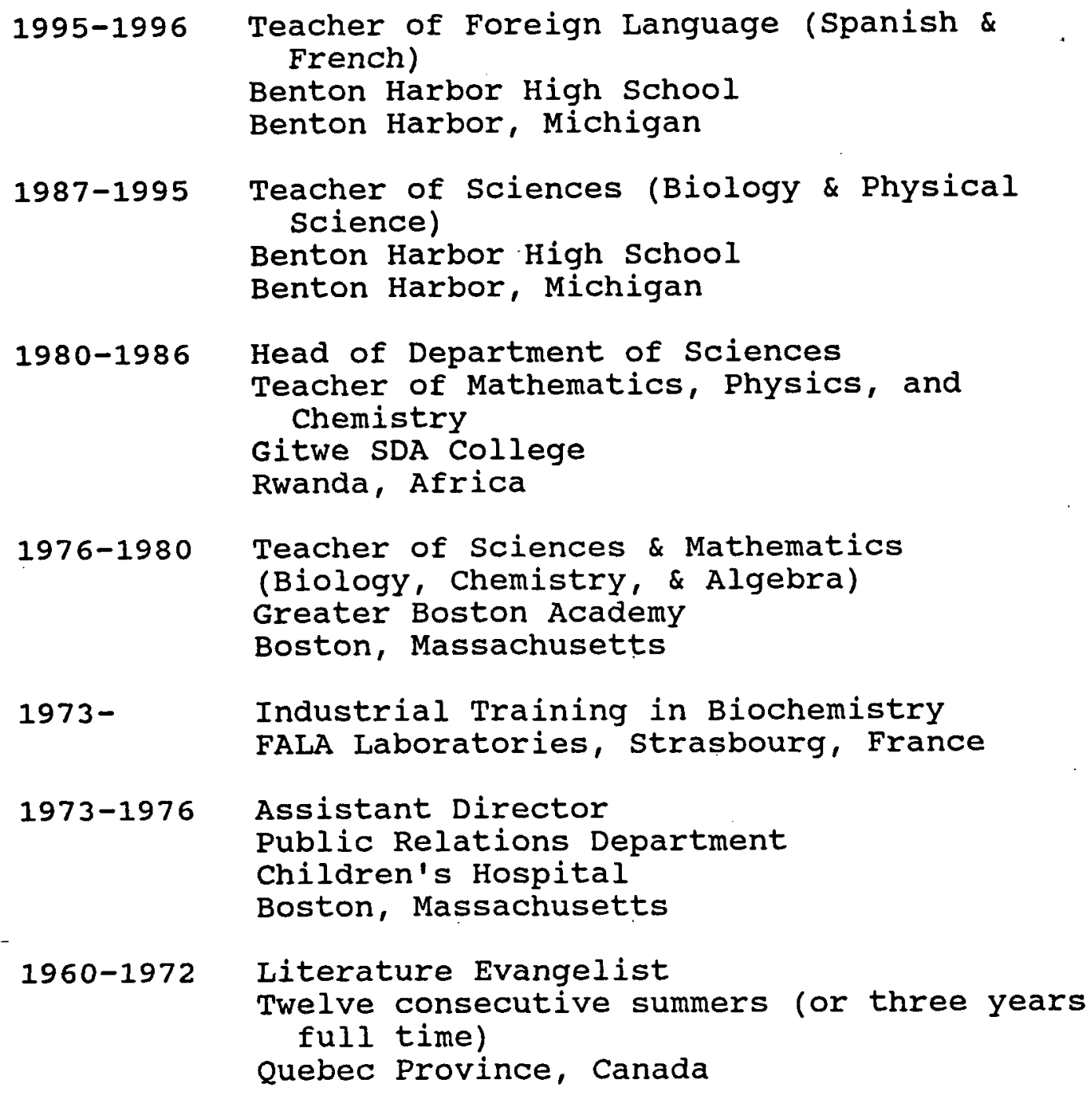

